\title{
The Jesuit Mission to New France
}




\title{
Studies in the History of Christian Traditions
}

\author{
General Editor \\ Robert J. Bast \\ Knoxville, Tennessee \\ In cooperation with \\ Henry Chadwick, Cambridge \\ Paul C.H. Lim, Nashville, Tennessee \\ Eric Saak, Liverpool \\ Brian Tierney, Ithaca, New York \\ Arjo Vanderjagt, Groningen \\ John Van Engen, Notre Dame, Indiana
}

Founding Editor

Heiko A. Oberman $\dagger$

VOLUME 151 


\title{
The Jesuit Mission to New France
}

A New Interpretation in the Light of the

Earlier Jesuit Experience in Japan

\author{
By
}

Takao Abé

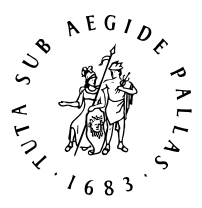

B R I L L 
B R I L L This is an open access title distributed under the terms of the CC-BY-NC License, which permits any non-commercial use, distribution, and reproduction in any medium, provided the original author(s) and source are credited.

An electronic version of this book is freely available, thanks to the support of libraries working with Knowledge Unlatched. More information about the initiative can be found at www.knowledgeunlatched.org.

Cover illustration: Historic Map of New France. Partie de la Nouvelle France dedié a Monseigneur le Marquis de Seignelay, et Lonré, Baron de Sceaux; conseiller du Roy en tous ses conseils.

Source: Library and Archives Canada/Credit: Hubert Jaillot/NMC 20685.

Library of Congress Cataloging-in-Publication Data

Abé, Takao.

The Jesuit mission to New France : a new interpretation in the light of the earlier Jesuit experience in Japan / by Takao Abé.

p. cm. - (Studies in the history of Christian tradition ; v. 151)

Includes bibliographical references (p. ).

ISBN 978-90-04-19285-0 (hardback : alk. paper)

1. Jesuits-Missions-New France. 2. Jesuits-Missions-Japan. 3. Canada-History-

To 1763 (New France) 4. Indians of North America-Missions-History-17th century. 5. Jesuits-Missions-New France-Historiography. 6. Canada-History-To 1763 (New

France)-Historiography. 7. Indians of North America-Missions-Historiography. I. Title. F1030.7.A34 2011

$971-\mathrm{dc} 22$

2010041728

ISSN $1573-5664$

ISBN 9789004192850

Copyright 2011 by Koninklijke Brill nv, Leiden, The Netherlands.

This work is published by Koninklijke Brill Nv. Koninklijke Brill NV incorporates the imprints Brill, Brill Hes \& De Graaf, Brill Nijhoff, Brill Rodopi and Hotei Publishing.

Koninklijke Brill NV reserves the right to protect the publication against unauthorized use and to authorize dissemination by means of offprints, legitimate photocopies, microform editions, reprints, translations, and secondary information sources, such as abstracting and indexing services including databases. Requests for commercial re-use, use of parts of the publication, and/or translations must be addressed to Koninklijke Brill NV.

This book is printed on acid-free paper and produced in a sustainable manner. 


\section{CONTENTS}

Introduction: Iberian and French Jesuits from an International Perspective

I. Review of Literature on the Jesuit Missions to Japan and New France

A. Historiography of the Jesuit Mission to Japan ……….... 17

B. Historiography of the Jesuit Mission to New France ..... 31

C. Towards a Synthesis of Historiographies ........................... 44

II. Interpreting Non-Christian Cultures: Jesuit Biases $\ldots . . . . . . . . . . . . . .4 \quad 47$

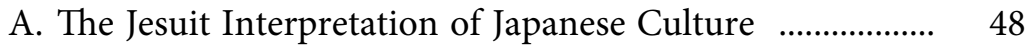

B. The French Jesuit Interpretation of Native Culture ........ 61

C. Jesuit Biases in Interpreting Non-Christian Cultures $\quad . . . . \quad 78$

III. Preaching, Winning Converts and Educating Them: Evolving Multifaceted Strategies ............................................. 81
A. Japan
B. New France 101
C. A New Paradigm for the Missionary Strategy in New France

IV. Organising a Mission for a Christian Community: Missionary Réductions Reconsidered

A. The Prototypes for Amerindian Réductions ……….......... 130

B. A Comparison between Japan and Paraguay .................... 135

C. The Réductions in New France in Comparison with the Paraguayan and Japanese Models

D. The International Evolution of Missionary Réductions 161

V. Accepting and Comprehending Christianity:

Non-European Practice of the Religion

A. Problems of Historical Epistemology 
B. Japanese Acceptance and Comprehension of Christianity ..................................................................... 168

C. Amerindian Acceptance and Comprehension of Christianity

Conclusion: The French Jesuit Mission Revisited 201

Bibliography of Works Cited 209 Appendices 221 Index 


\section{LIST OF ILLUSTRATIONS}

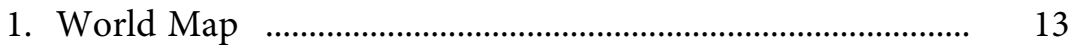

2. Map of Kyushu, Japan .......................................................... 14

3. Map of New France ................................................................ 15

4. First Ursuline Nuns with Native Pupils at Quebec ............. 86

5. Seventeenth-Century Japanese Folding Screens ................... 87

6. Huron Houses in Sainte Marie (replicas) .............................. 124

7. Church Building in Sainte Marie (a replica) ………............ 125

8. Altar for Native Converts in Sainte Marie (a replica) ......... 126

9. Japanese Mould for Medals and Crucifixes in the Late Sixteenth or Early Seventeenth Century ................................ 177

10. Seventeenth-Century Image of Native Women and Children Praying to God ........................................................... 186 
Takao Abé - 978-90-04-20965-7 Downloaded from Brill.comఠ4/26/2023 02:17:13PM via free access 


\section{INTRODUCTION: \\ IBERIAN AND FRENCH JESUITS FROM AN INTERNATIONAL PERSPECTIVE}

If interpreted in a broader international framework beyond North America rather than just within the regional history of New France, will the existing historical paradigms of the Jesuit missionary activity to Amerindians remain intact? This is the thematic issue that underlies this cross-cultural study. The Jesuit mission in seventeenth-century New France will be analysed as a series of incidents that developed, not simply as a domestic occurrence of North America, but out of the earlier mission of Father Francisco de Xavier in Japan. In this analysis, the Christian mission in Japan will be used as a tool to revise the currently accepted historical interpretations of the French Jesuit mission. Through a diachronic global comparison encompassing the period from the mid-sixteenth century to the mid-seventeenth century, this investigation attempts to add a new revisionist perspective to the conventional understanding of the New France mission.

More than half a century before French missionaries landed in North America in the early seventeenth century, another Jesuit group had already arrived in Japan. In 1549, the party of Father Xavier arrived at Kagoshima, on the southern tip of Japan. Among his accomplishments, French-educated Xavier had helped to establish the Society of Jesus [SJ] in Paris in 1534. Father Xavier's contact with Japan was but the first of many such visits. Iberian Jesuits from Portugal, Spain and Italy, under the patronage of the king of Portugal, followed. Although the Jesuit mission to Japan experienced some success during the second half of the sixteenth century, strict legislation promulgated by the Japanese central authorities eliminated the Christian missions in the early seventeenth century. Meanwhile, as the Iberian mission was ending in Japan, the French Jesuits were beginning their own mission to New France.

To understand the mission in New France, it must be discussed within both colonial North American and international contexts. Similarly the mission in Japan must be considered within the context of Iberian colonialism in this Asian country as well as within an international framework. Yet this international context has rarely, until now, been thoroughly 
investigated by a single historian, either in Japan or in the West. ${ }^{1}$ Apparently those researching the history of Japan and those studying that of New France have been unaware of each other's research. General histories of the Society of Jesus often deal with both missions in separate chapters, but the chapters do not draw comparisons. ${ }^{2}$ There is admittedly one historian whose work addressed both missions. Pierre-François-Xavier de Charlevoix, a French Jesuit Father of the eighteenth century, was the first and last individual to do so, but even he dealt with the respective missions in separate volumes with no attempt at synthesis.

It is clear that Japan was no longer an unknown country for French Jesuit authors in the eighteenth century. In 1715, almost thirty years before his own history of New France was published in 1744, Charlevoix completed a series of volumes on the Japanese mission. ${ }^{3}$ In this work, he described Jesuit activity there as if he himself had been a missionary in this archipelago. Because eighteenth-century Japan maintained no regular connections with Europeans, except via Dutch merchants, the only way that Charlevoix could have become acquainted with the ecclesiastical history of this oriental country was by reading Jesuit missionary reports on Japan. Joseph-François Lafitau, his French-Jesuit contemporary of the eighteenth century, was also familiar with Japan, though he too had never visited it. In his anthropological monograph on native North Americans, Lafitau refers to Yezo, or today's Hokkaido, as a possible land of origin for indigenous North Americans. ${ }^{4}$

1 The only possible exception may be Shenwen Li's Stratégies missionaries des jésuites français en Nouvelle-France et en Chine au XVII siècle (Saint-Nicolas, Québec: les Presses de l'Université Laval; Paris: Harmattan, 2001), which is based on a synchronic comparison of simultaneous events in the seventeenth century rather than a diachronic comparison based on historical cause and effect. Although Li's treatise presents the Jesuit contribution to the establishment of cultural ties between the Occident and the Orient, it does not present a revisionist interpretation that would affect existing perspectives on the Christian mission to New France.

2 E.g. Thomas J. Campbell, SJ, The Jesuits, 1534-1921: A History of the Society of Jesus from Its Foundation to the Present Time (New York: The Encyclopedia Press, 1921).

${ }^{3}$ Pierre-François-Xavier de Charlevoix, SJ, Histoire de l'établissement, des progrès et de la décadence du christianisme dans l'empire du Japon, où l'on voit les differentes révolutions qui ont agité cette Monarchie pendant plus d'un siècle (2 tomes, Rouen: Guillaume Behourt; Jacques Joseph le Boullenger; Pierre le Boucher, 1715.); and Charlevoix, Histoire et description générale de la Nouvelle France, avec le journal historique d'un voyage fait par ordre du roi dans l'Amérique septentrionale (3 vols., Paris: Didot, 1744).

${ }^{4}$ Joseph-François Lafitau, SJ, Moeurs des savauge amériquains comparés aux moeurs des premiers temps (2 tomes, Paris: Suagrain l'aîné \& Charles-Estienne Hocherau, 
The Jesuit priests in seventeenth-century New France were familiar with the mission to Japan because of the Society's tradition of global correspondence. The superiors of the respective missionary provinces, which by 1615 counted thirty-two all over the world, provided annual reports of their provinces. Such reports provided fellow Jesuits with an international exchange of information and advice. The successive superiors of the colonial French mission were included in this network. ${ }^{5}$

Some familiarity with Japan, associated with this global information exchange, can be detected even in the French reports on North America that referred to the Iberian mission in Japan. From time to time the Jesuits in New France visited their local superior in Quebec or Montreal, depending on where the colonial missionary station was, and they sent him annual journals. The Jesuit superior in New France included these reports in his own Relations, and transmitted them to the French Jesuit provincial at Paris, who supervised the colonial missions. Les Relations des Jésuites, or The Jesuit Relations, was the title of this series published in France from 1632 to 1673.

There are several references to Japan in this French series, references that are ignored in the histories of the Jesuit mission in New France. Father Paul le Jeune's Relation of the year 1635-1636 describes the Japanese nation as being just as superstitious as the native peoples of North America. He pointed to the Japanese belief in the need to assist the souls of the dead, which seemed to him as superstitious and absurd as that of the Amerindian Montagnais, or Innu. ${ }^{6}$ The Relation also cites Father Xavier, who wrote that, in Asia, there was an island, probably Japan, where residents were religious enough to cry from

1724), 32-33; Joseph-François Lafitau, SJ, Customs of the American Indians Compared with the Customs of Primitive Times (ed. William N. Fenton \& Elizabeth L. Moore, 2 vols., Toronto: Champlain Society, 1974), 45.

${ }_{5}^{5}$ Marc Jetten, Enclaves amérindiennes (Sillery: Septentrion, 1994), 30.

6 Although Father Le Jeune did not specify the source of information, he had obviously read Francisco de Xavier's letter of 29 January 1552, addressed from Cochin to his companions in Europe. In it, Father Xavier related that Japanese people, by paying a large amount in advance to Buddhist monks, believed superstitiously that it would attain a happier afterlife. See M. Joseph Costelloe, SJ (trans.), The Letters and Instructions of Francis Xavier (St. Louis, Missouri: The Institute of Jesuit Sources, 1992), Document [ep., hereafter] 96, pp. 329-30. From another point of view, there was a parallel with the Amerindian and Japanese belief in helping the souls of the dead, which Father Le Jeune was criticising, without acknowledging the similarity of this concern with Christian beliefs. Prayers and Masses were said in the Roman Catholic Church for those souls of the dead in Purgatory. 
excessive heart-felt joy. ${ }^{7}$ About the same time, Father Jean de Brébeuf, SJ, implied that the Japanese, unlike the Amerindians, were already perfectly civilised. Later, in the annual report of 1637, Father Le Jeune quoted Father Pierre Pijart in the Huron country, who had read an account on Japan. In 1640, Father Le Jeune also mentioned the possibility of reaching Japan and China via the Saint Lawrence and the Ottawa rivers. He suspected that what he took to be a sea west of these rivers would connect to the northern part of Nueva España, which he believed to be opposite Japan, not far across the Pacific Ocean. Other correspondents discussed this imaginary westerly route to Asia repeatedly in the Relations. In the report of 1659-60, Father Jérôme Lalemant, SJ, imagined the distance from Hudson Bay to Japan to be as short as 1420 leagues, or 6,800 kilometres, in other words only sixty per cent of the actual distance. ${ }^{8}$

As early as the sixteenth-century, the French regarded the mission to Japan as an exotic and peculiar experience for the Jesuits. For example, once when the Jesuit Father Émond Auger was preaching to the residents of Valence in the French countryside, he was unable to communicate easily with the local people who spoke a regional language. He was surprised at how foreign they seemed in their reaction to his evangelistic message; so foreign, in fact, that the people of Valence made him imagine that he was in distant Japan rather than in France. ${ }^{9}$

It is in the published Iberian correspondence on Japan where one finds the best evidence of the French Jesuits' familiarity with this eastern edge of Asia. Throughout the second half of the sixteenth century and the seventeenth century, numerous printed editions of accounts about the Japanese mission were published in Europe. Although historians have never asked whether French Jesuits read the mission-

7 The only two possible island regions that Xavier visited are the Moluccas and the Japanese archipelago. Among the existing letters of Father Xavier, the reference closest to Le Jeune's citation is the same letter as above. See ibid., ep. 96, pp. 331-32.

${ }_{8}$ This paragraph is based on Reuben Gold Thwaites et al, The Jesuit Relations and Allied Documents... [Relations, henceforth] (73 vols., Cleveland, OH: Burrows Brothers, 1896-1901), (Le Jeune) 8: $189 \&$ 273; 12: 241; (Brébeuf) 10: 210; (the route to Japan) 18: 237-39; 45: 221; 66: 67; (Lalemant) 45: 223-25.

9 A. Lynn Martin, The Jesuit Mind: The Mentality of an Elite in Early Modern France (Ithaca \& London: Cornell University Press, 1988), 226-27. Martin cites Émond Auger's manuscript letter to Borgia, Avignon, dating 30 January 1566; preserved as Gallia 81: Epistolae Galliae 1565-1568, f. 24v, Archivum Romanum Societatis Iesu, Rome. 
ary stories about Japan, there are numerous publications available on the subject of these Asian islands. The large number of publications makes it impossible today to determine through which particular volume French Jesuits acquired information on the Japanese experience. It is, however, possible to determine which languages were used for communication between Jesuits: French, along with Italian and Latin, although Latin was not commonly used. Before the Society of Jesus regulated its usage in 1576, forcing members to use Latin for official correspondence, many of the earlier French members received their theological education in Italy and were consequently far more fluent in Italian than in Latin. They wrote in Italian to their superior generals, such as Fathers Ignatius de Loyola, Diego Lainez and Francis Borgia, and to all other Spaniards. ${ }^{10}$ One thus needs to search for published reports on Japan in these three languages.

The reports on Japan were sent to Europe and published in various European languages. The correspondence from local regions was copied at least three times at the missionary station in Kyushu, the main western island. One copy remained in Japan and others were mailed via the Portuguese and later the Spanish colonies such as Macao, Malacca, Goa, Manila and Nueva España. From the year 1579 onwards, rather than being sent from various individual correspondents, the local letters were compiled into an annual report called Carta annua de Japão under the supervision of the superior of Japan. The Jesuits in Europe published the reports in several languages in order to reach more European readers. ${ }^{11}$

It is probably impossible to locate all the publications on the Japanese mission because they are spread throughout Europe and in former European colonies. Yet Johannes Laures, SJ, made an extensive search, based on the copies preserved as special collections in the libraries and archives in Japan. ${ }^{12}$ His bibliographical study provides sufficient data to prove the environment in which French Jesuits in Europe were able to read the Iberian missionary accounts (See table 1 and appendix 1). For the period 1552 to 1701, for example, the publications

\footnotetext{
${ }^{10}$ Martin, op.cit., 55-56.

${ }^{11}$ Matsuda Kiichi, Kinsei shoki nippon kankei nanban shiryô no kenkyû (Tokyo: Kazama shobô, 1967), 96-99.

12 Johannes Laures, SJ, Kirishitan Bunko: A Manual of Books and Documents on the Early Christain Mission in Japan (3rd ed., Tokyo: Sophia University, 1957). For selected details of the Jesuit publications, see appendix 1 .
} 
are available in nine languages, at least: Portuguese, Spanish, Italian, Latin, French, German, Dutch, English and Polish. Laures's list includes 448 editions, of which 142 are in Italian, ninety-two in Latin and sixty in French. The Italian editions predominated during the sixteenth century. Yet, in the seventeenth century, when the French Jesuits began their mission in North America, Latin and French were used more frequently. Even just counting the small archival collections in Japan, there were at least 294 editions published in Europe in the three languages easily understood by French Jesuits. A more extensive search focussing on the French editions, held in the USA and France, locates twenty-three additional publications, which increase the figure of sixty French editions up to eighty-three. ${ }^{13}$ Therefore, the actual figure in the three languages may exceed 294 quite considerably, which means that there is no doubt that many printed reports were available to French Jesuits. It seems obvious that the Jesuits in France were able to learn from their Iberian brethren who had worked in Japan, by means of these circulated European publications.

Table 1. European-Language Publications of the Missionary-Mostly JesuitCorrespondence on Japan, 1552-1701

(based on the bibliography in Johannes Laures, Kirishitan Bunko, 1957)

\begin{tabular}{lcrrrrrrrr}
\hline Period & $\begin{array}{l}\text { Portuguese/ } \\
\text { Spanish }\end{array}$ & & & & & & & & \multicolumn{2}{c}{$\begin{array}{c}\text { Stalian } \\
\text { Total }\end{array}$} \\
\hline $1552-1601$ & 16 & 69 & 28 & 13 & 13 & 0 & 0 & 0 & 139 \\
$1602-1651$ & 64 & 60 & 36 & 27 & 8 & 4 & 2 & 1 & 202 \\
$1652-1701$ & 21 & 13 & 28 & 20 & 10 & 6 & 9 & 0 & 107 \\
Subtotal/ & 101 & 142 & 92 & 60 & 31 & 10 & 11 & 1 & 448 \\
Total & & & & & & & & & \\
\hline
\end{tabular}

${ }^{13}$ The search is based on two online databases. One is the US library database of RLG's Eureka ${ }^{\star}$ on eureka.rlg.ac.uk/Eureka/, and the other is the Bibliothèque nationale de France on www.bnf.fr/. Although the British and Vatican collections also include early modern missionary publications, neither the Vatican database on www.vatican library.vatlib.it/bavt/ nor the British one, called Copac, on copac.ac.uk/copac/ provides any additional editions beyond the ones in Laures's extensive bibliography. 
The historiography of the French Jesuit mission has never included the Iberian mission in its discussion, on the assumption that it was unrelated to the history of New France. This historiography calls for revision. The French missionaries were aware that they were not the first group of evangelists to preach outside Europe. From the frequent publications in several languages, they knew that sixty or more years earlier Father Francisco de Xavier and his pioneer successors in Japan had already had as exotic an experience as they were having in North America. In the minds of French missionaries, the mission to Japan was meaningful and worthy, although later historians have ignored or overlooked this connection. As stated above, in the eighteenth century, Father Charlevoix dealt with the respective missions separately, as if they had no relevance to each other. Ever since his substantial and influential monographs, historians have followed his framework, thereby excluding, for almost three centuries, the French memory of Japan from discussions of the French Jesuit mission in colonial North America. As the review of literature on the Jesuit missions in the following chapter argues, historians have always discussed the Jesuit mission exclusively in a North American context as though French missionaries were ignorant of Father Xavier and other Iberian missionaries in Japan.

It is high time for the missionary history of New France to be discussed in a comparative framework. A prototype for the French Jesuit mission can be discovered in sixteenth-century Japan, which, without doubt, influenced the later mission in North America. What appears to have been original to New France may already have been experienced and narrated by Iberian missionaries, who worked unceasingly in sixteenth-century Japan. Interpretations that appear to be reasonable to Canadianists should now be placed in a broader perspective comprising the Iberian mission in the previous century. Existing interpretations of the French mission should take into account the experience of Iberian priests, in order to distinguish what was unique to New France, while of course not overlooking the fact that each mission shared certain common Jesuit outlooks and aims. The case of the mission to Japan provides an important clue to this international approach.

There was also a by-product of the missionary endeavours. The Jesuit missions to these two regions inevitably involved intercultural interactions between Euro-Christians and non-European nonChristians. To some degree, the Jesuit mission attempted acculturation 
of non-Christians and of colonial settlers as well. Christian beliefs, as practised by Japanese converts, may well throw further light on the limits of acculturation. The comparative case study of Japan could well lead to more plausible identification of native Amerindian customs than a narrow contextual assumption based only on French source material.

Another consideration is possible from the comparative view of culture. A thorough analysis of the Japanese case could well shed light on the apparent cultural biases both in the Jesuit missionaries' approaches to non-Christian peoples and in their observations of foreign societies in general. This identification of the missionaries' Euro-Christian biases may also shed light on ideologically-determined French misperceptions that have been accepted unconditionally as accurate interpretations by historians of New France.

The influence of the Japanese experience on the French Jesuits is most clearly seen in missionary approaches to the native peoples. The missionary methods can be seen as encompassing the following five aspects: interpreting local cultures; winning converts; the education of proselytes; the indigenous practice of Christianity; and, more generally, the establishment of the missionary church. A comparison of the two regional approaches may reveal both similarities and differences. Although external conditions in the two cases have resulted in differing manifestations, such superficial differences could sometimes be seen as concealing fundamental similarities in evangelistic methodology.

There were three kinds of approaches used by missionaries in order to achieve success. First, they interpreted non-Christian cultures; second, they preached, won converts and then educated them; and third, they established indigenous Christian communities. In the chapters that follow chapter one, which is the review of literature on the Jesuit missions, an attempt will be made to analyse each of these methods and approaches in turn.

To begin with, chapter two will focus on the importance which the Iberian and French missionaries attached to interpreting non-Christian cultures in order to make their preaching more effective. The missionaries encountered a deep gulf between Christian and non-Christian cultures. From a contemporary sixteenth- or seventeenth-century standpoint, Jesuit priests were masters of Euro-Christian knowledge. Therefore, they were capable of understanding non-Christian cultures at least in their own systematic way. Within the confines of earlymodern western intellectuals, their analysis, while biased, was the best 
available at the time. Historians today, however, often note that the Jesuit interpretation of native North Americans was biased and needs to be treated carefully.

A more comprehensive analysis comprising the Jesuit interpretation of Japan will identify the missionary biases and reduce the needless scepticism of them. One will learn that, however biased the French missionary observations of the Amerindian peoples and cultures may have been, they were not as biased as they are commonly considered to have been. In Canadian historiography, the lack of written Amerindian documents has forced westerners to qualify missionary interpretations by speculation. Without written documentation, it is impossible to tell how accurate the Jesuit interpretation of indigenous culture is. By contrast, there exist today Japanese historical sources, relics and remains that can help to identify the mistakes and illusions of the Iberian Jesuits. Japan's language, culture and national polity have survived, which thus allows researchers today to view the misinterpretations made by missionaries of sixteenth-century Japanese. This identification of biases can then be transferred to the North American context.

Preaching, winning converts and educating them were the next composite methods, and are discussed together in the third chapter. Preaching and winning converts were too intertwined with educating Amerindians to be discussed separately. Education was a vital part of winning converts. It aimed at conscripting young Amerindians to act as liaisons between the Jesuits and indigenous communities. It was one of the most fundamental tasks set forth in preliminary discussions which led to the establishment of the Society, and was just as important as actual conversion to Christianity. While the Jesuits approached socially influential Japanese adults for patronage, the targets of education were boys who would eventually play a vital role in helping Jesuits to establish their colonial church. In order to educate these young lay assistants in Christianity and European languages, including Latin, Iberian Jesuits chose boys from influential kinship groups and even dispatched some to Europe. French Jesuits had a similar approach, but achieved far less success. It is important to understand the influence of the Iberian educational example on the French mind and how this influence led French missionaries to fail.

In Japan, the methods used for winning neophytes during this stage were constantly revised throughout the sixteenth century. The approach by Father Xavier and his successors in Japan began and developed gradually from Father Xavier's reflection on his first mission during 
his brief sojourn in India. The more Jesuits came to understand local people in Japan, the more effective methods they developed for gaining more converts by adapting methods to local culture. This evolution of approaches was also the case with French Jesuits in the seventeenth century. This transition, however, should not be considered as having been invented and developed originally by French missionaries in New France. A comparison of the two missions will reveal how much of the French methodology was original, and how much was in emulation of the Iberians.

This third chapter raises two Canadian issues for reconsideration. In the first place, the international consideration will revise the existing interpretation of the methodological difference between the Franciscans and the Jesuits in the Saint Lawrence region. Were the Franciscan missionaries cultural absolutists compared with the Jesuit missionaries, as has been commonly maintained by the histories of New France? A better answer can be found in a more extensive discussion that involves the period starting from the mid-sixteenth century rather than just the seventeenth century. The answer will be negative, and will revise the existing perspectives drawn from the narrow framework of New France. ${ }^{14}$

In the second place, it is commonly accepted by Canadianists that educating children was of the utmost importance, and only later did the French Jesuits target adults. Is this really the most appropriate interpretation of the Jesuit approach? The Iberian examples will suggest that French Jesuits did not simply shift the targeted age groups from children to adults, but that they made a more complex adjustment in their approach.

The third missionary approach was the establishment of mission communities called réductions, which chapter four will examine in a comprehensive manner. The French Jesuit missionaries designed native Christian communities. Within the realm of Canadian history, they are firmly believed to have been based entirely on Paraguayan models, which were called reducciónes. This stereotypical interpretation has prevented investigating further questions, such as 'What was the prototype for the Paraguayan model?' and 'Why did the

${ }^{14}$ For the existing perspectives of the Franciscans and Jesuits in their cultural attitudes, see Bruce G. Trigger, The Children of Aataentsic (Montreal \& Kingston: McGillQueen’s University Press, 1976), 376-81 \& 467-69. 
réductions of New France differ from the reducciónes of Paraguay in some aspects?'.

The answers to these questions will be found in a more comprehensive analysis that includes Japan, Paraguay and New France. The argument will take account of fundamental Euro-Christian activity and the institutional arrangements of the Roman Catholic Church. It will also distinguish the Jesuits' creations of new missionary elements from their introduction of basic Christian customs that predated the mission to Japan. A comparison will be made initially between Japanese Christian villages and Paraguayan missionary settlements, and then between the settlements of Paraguay and those of New France. The Jesuit experiment in creating non-European Christian communities in Japan of the previous century presents the concepts and precedents for both the réductions and the reducciónes.

Next, it is important to understand how Amerindians and Japanese practised Christianity, since the above evangelistic approaches, which the missionaries revised to suit them, were the primary determinants for the acceptance and comprehension of the faith. This is the subject of the fifth chapter. The annual Jesuit reports frequently applaud the converts both in Japan and in New France. Without fully investigating the indigenous practice of Christianity, recent historians have merely debated whether native Canadians were socially subordinated by converting to Christianity. ${ }^{15}$ Yet such perspectives, confined by the degree of missionary success, do not reveal a true picture of the Christian practice by the indigenous people.

If one examines missionary accounts from the point of view of an historian familiar with both European Christianity and Japanese customs, one gains a far greater insight into the non-European ways of practising the Christian faith, and of the native customs that lived on after conversion. With the Iberian Jesuits' case in mind, a consideration of the practice of Amerindian converts will shed light on neglected aspects of autochthonous customs that were viewed through the missionary lens without any attempt to identify those customs culturally. The converts in New France seemed to have created a new version of Christian practice, retaining most of their native habits in some

${ }^{15}$ Karen Anderson, Chain Her by One Foot: The Subjugation of Women in Seventeenth-Century New France (London \& New York: Routledge, 1991); and Carole Blackburn, Harvest of Souls: The Jesuit Mission and Colonialism in North America, 1632-1650 (Montreal \& Kingston: McGill-Queen's University Press, 2000). 
form or another, while at the same time being recognised by Jesuits as model Christians.

Finally, in the concluding chapter, with these methodological discussions in mind, a more appropriate interpretation of the French Jesuit mission will be possible. The French mission will be considered within the context of the international influence that originated in the previous century. Also, in order to revise accepted interpretations of Christianisation among the Amerindian populations, missionary acculturation of native neophytes in New France will be compared to the same process among Japanese converts. Accepted interpretations, which have been based solely on a seventeenth-century North American perspective, will be seen to be inappropriate, once these interpretations are placed in an international perspective beginning with Father Xavier's mission to Japan in the sixteenth century. Although there may be more points of view, this comparative discussion in a single monographic study is a first important step towards an international perspective of the French Jesuit mission. 


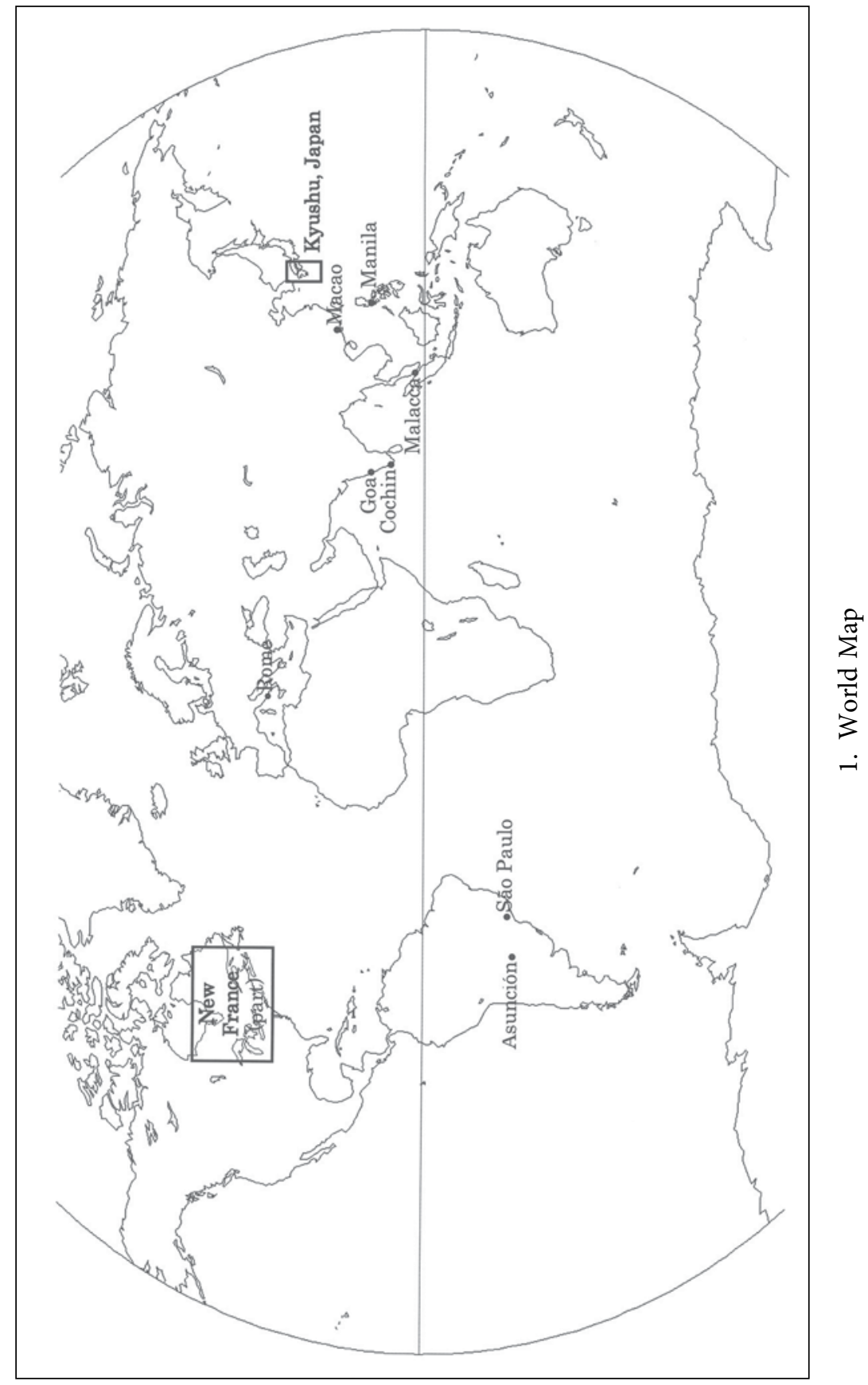




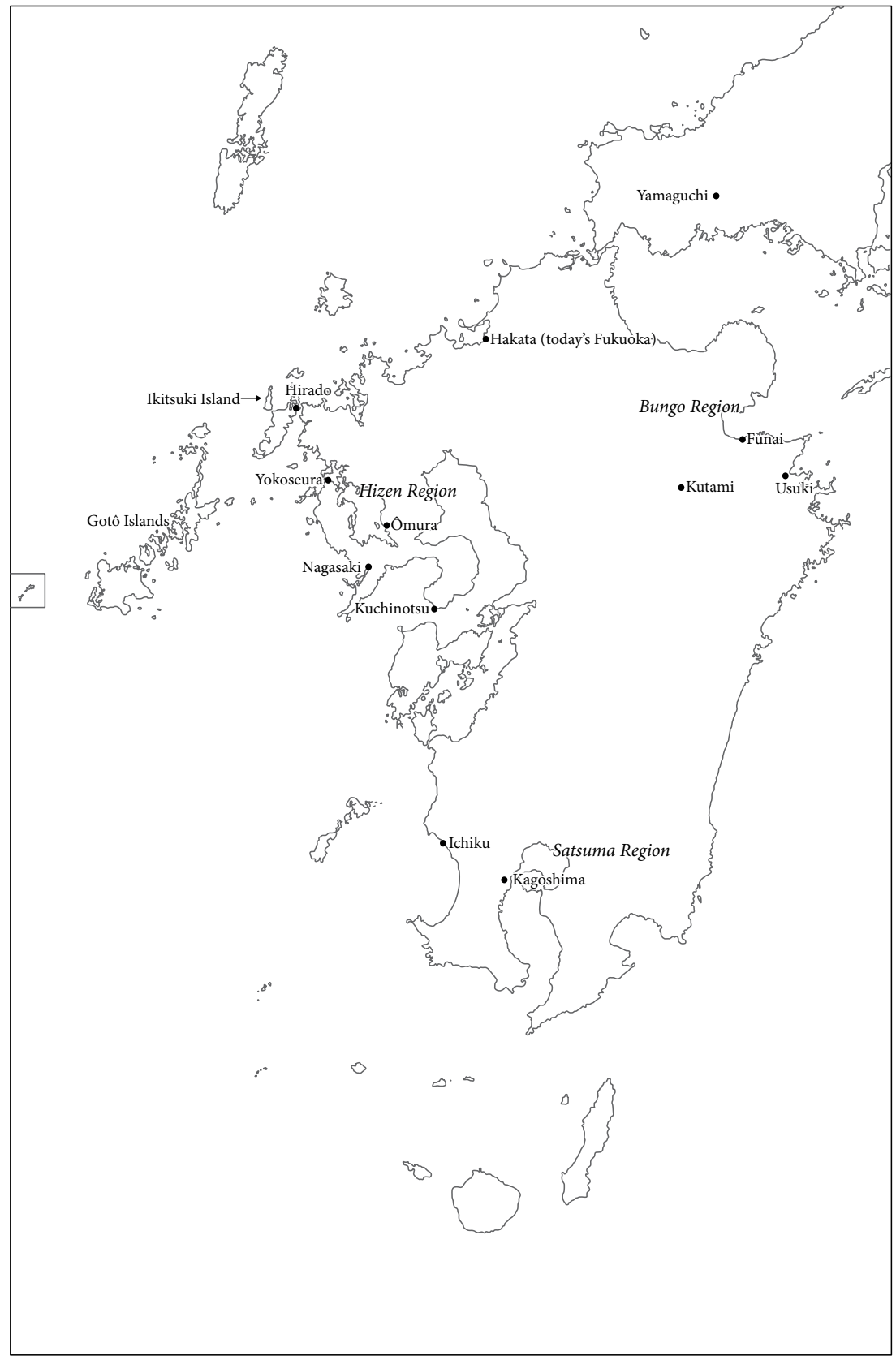

2. Map of Kyushu, Japan 


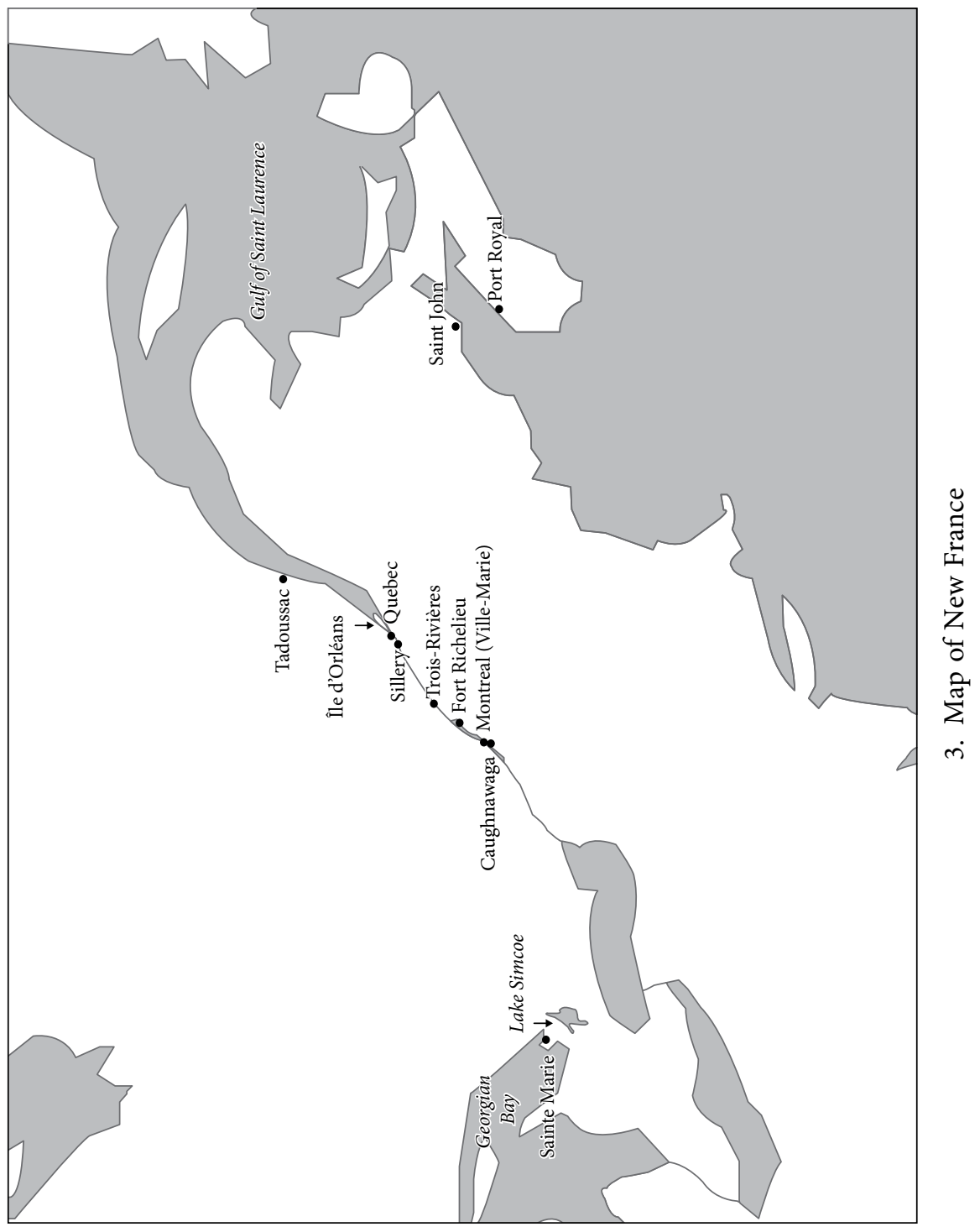


Takao Abé - 978-90-04-20965-7 Downloaded from Brill.comఠ4/26/2023 02:17:13PM via free access 


\section{CHAPTER ONE}

\section{REVIEW OF LITERATURE ON THE JESUIT MISSIONS TO JAPAN AND NEW FRANCE}

For over three centuries, scholars have studied the early Jesuit missions to Japan and New France. Academic works on the Japanese mission were originally produced by westerners, who were joined by Japanese scholars at the end of the nineteenth century. Scholarly studies of the Canadian mission have been made in France and North America since the eighteenth century. Based on sixteenth- and seventeenth-century sources, modern students have developed their perspectives on the Jesuit missions.

Although much has been written and published on these two missionary fields, there is room for further research. For instance, the Japanese mission, which provides both European and non-European perspectives, is overlooked by Canadianists. An historiographical overview of the Roman Catholic mission in Japan during the sixteenth and seventeenth centuries will demonstrate the need for revision.

\section{A. Historiography of the Jesuit Mission to Japan}

The academic studies about the Christian missions in Japan can be divided into five groupings, of which four are western and one, Japanese. The first group consists of clerical editors of missionary documents to the end of the eighteenth-century. The second includes nineteenthand early twentieth-century westerners, the first ones to attempt modern historical writing on this subject. The third group, in the twentieth century, consists of specialists in ecclesiastical archives. In the fourth category is a broader spectrum of western students, mainly of the second half of the twentieth century. Finally a fifth group includes Japanese scholars who balanced western interpretations with their own analyses of the Japanese aspects of missionary history.

\section{The Eighteenth Century}

Although publications on the mission in Japan began as early as the seventeenth century, most of these works in the first group, including 
those by Luis de Guzmán and Daniello Bartoli, did not go beyond mere compilations of Jesuit correspondence. ${ }^{1}$ Thus, an historiographical overview can only begin in the eighteenth century with Pierre-FrançoisXavier de Charlevoix, SJ (1682-1761). It was Father Charlevoix whose analytical and reconstructive style of description first bridged the gap between the reprinting of missionary letters and modern historiography based on primary sources. His history of attempts to convert the Japanese to Christianity remained in print through three revised editions for over a century, from the first edition of 1715 to the fourth edition of $1844 .^{2}$

Charlevoix's history is a chronicle of the Jesuit missions and of the Japanese authorities with whom missionary priests dealt. While admitting that the missionaries were deported or executed, and ultimately failed in their mission, throughout his monograph Charlevoix praised both the evangelistic efforts of the church and the strong faith of its congregations. He revealed a story of the Japanese church that was planted by and grew up under the Jesuits, and then was destroyed by central Japanese rulers.

\section{The Nineteenth and Early Twentieth Centuries}

After Father Charlevoix, modern western scholars in the nineteenth and early twentieth centuries, who represent the second group, kept track of the evangelistic heroes who led the missionary church in Japan. The scholars in this category include Léon Pagès (1814-86), Louis Delplace, Hans Haas (1868-1934), Otis Cary (1851-1932) and James Murdoch (1856-1921). Because these earlier historians had extremely limited access to Japanese sources, insufficient evidence in Europe and in Japan hampered their academic influence upon later historians.

In his Histoire de la religion chrétienne au Japon depuis 1598 jusqu'à 1651, Léon Pagès, a civil Christian historian, viewed the Japanese church

${ }^{1}$ E.g. Luis de Guzmán, SJ., Historia de las Missiones de la Compañía de Jesus (1601, revised in 1891) and Daniello Bartoli, SJ, Giappone: Istoria della Compagnia di Gesu (1660, Milano: Spirali, 1985). Bartoli (1608-1685) in Italy was in charge of compiling a chronology of the Jesuit missions in the Italian language for the Society of Jesus.

${ }^{2}$ Pierre François Xavier de Charlevoix, Histoire de l'établissement, des progrès et de la décadence du christianisme dans l'empire du Japon, où l'on voit les différentes révolutions qui ont agité cette Monarchie pendant plus d'un siècle (Rouen: Guillaume Behourt; Jacques Joseph le Boullenger; Pierre le Boucher, 1715.); Histoire et description $d u$ Japon ( $4^{\mathrm{me}}$ édition, Tours: $\mathrm{A}^{\mathrm{d}}$ Mame et $\mathrm{C}^{\mathrm{ie}}, 1844$ ). 
sympathetically. He devoted almost his entire work to praising the piety and unvanquished faith of the converts, while at the same time condemning the Japanese political authorities and Protestant Dutch traders for the cruel torture and death suffered by local Christians and missionaries. Despite his lack of analytical subtlety, his detailed narration became an important and oft-cited work since it was the first major, western publication on the subject of Japanese history after modern Japan resumed diplomatic relations with European states in $1854 .^{3}$

In the early twentieth century, for the first time, western historians began to use Japanese documents, which they consulted while actually living and studying in Japan. At the same time, European historians continued to write about Jesuits in Japan without actually visiting the country. In 1909, Louis Delplace, SJ, wrote his Le catholicisme au Japon, which was no more than a modern version of Charlevoix's history, with additional material from missionary correspondence. ${ }^{4}$

The first publications by westerners living in Japan appeared in German and English. In German, one of the outstanding studies was Hans Haas's Geschichte des Christentums in Japan (1902-04), which deals with the first two decades of the Jesuit mission, from 1549 to 1570. This Protestant missionary showed some cultural familiarity with Japanese spirituality, gained from first-hand experience in the archipelago. At the same time, his adherence to Christian theology led to his appreciation of early Jesuit evangelistic work. ${ }^{5}$ In English, Otis Cary, an American

${ }^{3}$ Léon Pagès, Histoire de la religion chrétienne au Japon depuis 1598 jusqu'à 1651 (2 vols., Paris: Charles Douniol, 1869-70). Pagès's other publications include Histoire des vingt-six martyrs japonais dont la canonisation doit avoir lieu à Rome le jour de la Pentécôte 1862 (1862); La persécution des chrétiens au Japon et l'ambassade japonaise en Europe (1873); La déportation et l'abandon des morts: Cimètiere de Mery (1875) and 'Cerqueira, Conference Held by the Bishop Cerqueira on the Subject of Slaves Bought or hired and transported out of Japan, in September 1598, extracted from the Archives of the Academy of History in Madrid by L. Pagès', Japan Weekly Chronicle 29 Jan. 1902: $83-85$. 10).

${ }^{4}$ Louis Delplace, SJ, Le catholicisme au Japon (2 vols., Bruxelles: Maline, 1909-

${ }^{5}$ Hans Haas, Geschichte des Christentums in Japan (2 vols., Tokyo: n. p., 1902-04). Haas also published the following monographs and treatises on Japan and related subjects: Die Sekten des Japanischen Buddhismus: Eine Religionswissenschaftlich Studie (Heidelberg, 1905); 'Die Religion der Japaner-2. Der Buddhismus', in Edvard Lehman \& A. Lehman (eds.), Die orientaliscen Religionen (Berlin \& Leipzig: B. G. Tübner, 1906), 221-54; Japans Zukunftsreligion (2. Aufl., Berlin: K. Curtis, 1907); 'Amida Buddha unsere Zuflucht': Urkunden zum verständnis des Japanischen SukhavatiBuddhismus (Göttingen: Vandenhöck \& Ruprecht; Leipzip: J. C. Hinrichs, 1910); Bibliographie zur Frage nach den Wechselbeziehungen zwischen Buddhismus und 
Protestant missionary in Japan, shared with his predecessors an interest in the development and decline of the first Japanese mission during the preceding three and a half centuries. His history of Christianity in Japan ${ }^{6}$ is worth citing because its discussion of missionary failure considered also the changing political and economic environment of EuropeanJapanese diplomatic relations. Like his ecclesiastical contemporaries, however, Cary was unable to revise the written observations of early modern Roman Catholic correspondents.

In the same decade as the monographs of Haas and Cary, a more comprehensive history appeared in print. A History of Japan during the Early Foreign Intercourse is the second volume of James Murdoch's three-volume history. ${ }^{7}$ In an attempt to revise the ecclesiastical approach that had been dominant since Charlevoix, Murdoch consulted not only European documents but also Japanese sources. For this demanding endeavour, he sought help from his Japanese colleague Isoo Yamagata. Murdoch's secular background also escaped glorification of the Christian converts. To a considerable extent, he examined non-religious incidents in politics and international relations when discussing the mission. Consequently his monograph placed greater emphasis on political relations between missionaries and the Japanese authorities.

\section{Specialists in Ecclesiastical Archives in the Twentieth Century}

It was only after the 1920s that German historians began to investigate the Japanese mission. These historians, who never visited Japan, let alone lived there, formed part of a third group. They uncovered new archival missionary sources. Among this group is the Franciscan Father Dorotheus Schilling (1886-ca.1960s) and two Jesuits, Georg Schurhammer (1882-1971) and Josef Franz Schütte. While sharing

Christentum (Leipzig: J. C. Hinrichs, 1922), Buddha in der abendländlichen Legende (Leipzig: J. C. Hinrichs, 1923). His interest in Japan grew to include the Ainu in his Die Ainu und ihre Religion (Leipzig: A. Deichert, 1925).

${ }^{6}$ Otis Cary, A History of Christianity in Japan: Roman Catholic, Greek Orthodox, and Protestant Missions (2 vols., New York: Fleming H. Revell, 1909; reprint in 1976 as one volume by Tuttle in Ruthland, Vermont, \& Tokyo, Japan).

${ }^{7}$ James Murdoch and Isoh (sic) Yamagata, A History of Japan during the Century of Early Foreign Intercourse (1542-1651) (Kobe: Kobe Chronicle, 1903). He first published this work as an independent monograph. He later expanded his work into three volumes. He published a book on the previous period of Japan as the first volume of A History of Japan in 1910. Although he passed away before seeing a printed copy of the third volume which dealt with the years 1652-1868, Joseph H. Longford and L. M. C. Hall completed its publication in 1926. 
with preceding authors an admiration for individual Christian missionary heroes, these three specialists at least inspired a source-based historicism among later students. Because their publications brought more primary sources to light, Charlevoix, Pagès, Haas and Cary began to be referred to less frequently in source citations in the second half of the twentieth century.

Dorotheus Schilling, OFM [the Order of the Friars Minors], contributed to the study of the Japanese missions by editing archival manuscripts, especially those of Luis Frois, SJ, and Avila-Girón, a Spanish merchant, whose documents had been extant for over three centuries. After searching for Jesuit documents copied in Macao, Schilling found the manuscript of Luis Frois's Historia de Iapam. He discovered Father Frois's manuscript written between 1583 and 1593, in Toulouse, France, in 1931, and another manuscript written between 1578 and 1582, in Lisbon in $1933 .^{8}$ The part from 1578 to 1587 had not previously been known. Also in 1933-35, in collaboration with Fidel de Lejarza, Schilling published Avila-Girón's second edition of Relación del Reino de Nippon, which had remained in manuscript form since the early seventeenth century. Besides his exploration of original sources, Schilling's interest extended to the Jesuits' educational and technological contributions to Japanese society, as well as Japanese politics and religion during the period of the early missions. ${ }^{9}$

While also covering other themes extensively, the studies of Georg Schurhammer, SJ, were concerned with two Jesuit missionaries, Luis Frois and Francisco de Xavier of the sixteenth century. In the 1920s, Schurhammer edited another part of the manuscript of Luis Frois's Historia de Iapam [or Japam] and published it in a German translation. $\mathrm{He}$ also uncovered and edited Xavier's correspondence. His archival investigation of original sources helped him publish numerous monographs and treatises on the Jesuits and related matters. His study uncovered other documents concerning the Portuguese colonies. In addition, his religious interest grew to include Japanese Shintô. ${ }^{10}$

\footnotetext{
${ }^{8}$ Matsuda Kiichi, 'Kaidai', in Matsuda Kiichi \& Kawasaki Momota (trans.), Furoisu Nipponshi (Tokyo: Chuôkôronsha, 1977-1980), 27-28.

Doroteo Schilling, OFM, \& Fidel de Lejarza (eds.), 'Relación del Reino de Nippon', Archivo Ibero-Americano 36 (1933): 481-531; 37 (1934): 5-48, 259-75, 392-434, 493554; 38 (1935): 103-30, 216-39, 384-417; and Dorotheus Schilling, 'Neue Funde zur História de Japão von Luis Frois S. J.', Zeitschrift für Missionswissenschaft 23 (1933): 337-43. See appendix 2 for Schilling's list of other publications.

${ }^{10}$ Georg Schurhammer \& E. A. Voretzsch (Hrsg. \& Übers.), Die Geschichte Japans (1549-1578) (Leipzig: Verlag der Asia Major, 1926); Georg Schurhammer, SJ, \& J. Wicki,
} 
Schurhammer's academic quest to discover Jesuit documents was followed by that of another German Jesuit, Josef Franz Schütte. Schütte's exploration of the missionary sources started in Rome where he was assigned to the Jesuit archives, thereby gaining easy access to missionary sources. His research extended to manuscript material on the Japanese missions in the Jesuit archives and in the Vatican library in Rome, including Japanese Christian writings and drawings. His major work, based on the Jesuit-archival documents, is Valignanos Missionsgrundsätze für Japan. In the 1950s, he began to do research in Portugal and Spain. In Madrid, he discovered Luis Frois's original text on Japanese culture, and published it in German in 1955. In the early 1960s, he also created a bibliography of Japanese sources located in the Real Academia de la Historia, Madrid. In the same years, he made a significant contribution to Japanese missionary studies when he found the text of Igreja do Japão, which was written by João Rodriguez-Tçuzu in the seventeenth century. He also found new material in East Asia. Finally in 1968, his decades of research culminated in Introductio ad Historiam Societatis Jesu in Japonia, 1549-1650, an analytical description of the Jesuit missions in Japan. ${ }^{11}$

\section{A Broader Spectrum of Western Historians}

Contemporaries of these German clergymen were able to use recentlydiscovered sources for their studies. The major historians in the second and third quarters of the twentieth century include Johannes Laures, SJ (1891-1959), Charles Ralph Boxer (1904-2000) and George Elison (1937-), who represent the fourth historiographical group. These three historians finally attempted a synthesis based on both European and oriental scholarships.

Although Johannes Laures was among the last generation of historians to take an heroic approach to the Jesuit mission, he did make a vital contribution to Japan-based archival research of Jesuit documents. His manual of Jesuit books and documents on Japan helped scholars to comprehend

SJ(eds.), Epistole S. Francisci Xavierii aliaque eius scripta (2 Tomus, Romæ: Monumenta Historica Soc. Jesu, 1944-45). See appendix 2 for Schurhammer's numerous publications.

${ }^{11}$ Josef Franz Schütte, SJ, Introductio ad Historiam Societatis Jesu in Japonia, 15491650, ac Prooemium ad Catalogos Japoniae Edendos ad Edenda Societatis Jesu Monumenta Historica Japoniae Proylaeum (Romae: Institutum Historicum Soc. Jesu, 1968). For other works by Schütte, see appendix 2. 
the mission's extensive publications in diverse languages. ${ }^{12}$ His most analytical work on the Japanese missions is Geschichte der katholischen Kirche in Japan, ${ }^{13}$ which deals with these missions from the period of Xavier to the nineteenth century. Like his predecessors, he described the rise and fall of the missions while estimating their degree of success. In addition, he examined the reasons for the success and failure of proselytisation, while at the same time considering the feudal Japanese rulers' intentions, in support or persecution of Christians. The monograph's academic weakness is Laures's all too rare indication of source material, which may have been the result of his publisher's decision to target general readers or perhaps by the author's own intention to publish only a short monograph.

The access to both European and Oriental sources is more clearly evident in the work of Charles Ralph Boxer, The Christian Century in Japan, 1549-1650, published in 1951. ${ }^{14}$ Not only did Boxer take advantage of discovered or edited sources but also he contributed to publishing western manuscript sources. He investigated the growth of the missionary church from a broader perspective rather than solely in terms of the Jesuit priests, who were described not only as diplomats but also as traders. Also, he paid special attention to the Japanese brothers and servants whose vital rôles had been underestimated by both his ecclesiastical contemporaries and subsequent historians. The Japanese converts and martyrs were also favourably noted. His work, though written from a western viewpoint, represented a revisionist perspective in Japanese mission studies. Up to that time, scholars had paid attention only to European priests and their political counterparts mainly through missionary language and terminology.

By extensively consulting Japanese printed sources in his Deus Destroyed of 1973, George Elison delved into the problems and limits of the Jesuit mission far deeper than previous westerners. ${ }^{15}$ From an

\footnotetext{
12 Johannes Laures, SJ, Kirishitan Bunko: A Manual of Books and Documents on the Early Christian Missions in Japan (1940, 3rd ed., Tokyo: Sophia University, 1957).

${ }_{13}$ Johannes Laures, SJ, Die Geschichte der katholischen Kirchen in Japan (Kaldenkirchen: Steyler, 1956). Its English edition appeared in print two years earlier under the title of The Catholic Church in Japan: A Short History (Tokyo: Tuttle, 1954).

${ }^{14}$ C. R. Boxer, The Christian Century in Japan, 1549-1650 (Berkeley \& Los Angeles: University of California Press; London: Cambridge University Press, 1951).

${ }^{15}$ George Elison, Deus Destroyed: The Image of Christianity in Early Modern Japan (Harvard East Asian Monographs 141; Cambridge, MA: Council on East Asian Studies, Harvard University, 1973). His other works are included in George Elison \&
} 
acculturating point of view, he contended that Jesuit Christianisation was doomed by forces both within and without. He pointed to the limitations of the Christian influence upon Japanese society. By dealing with the failure of the Christian mission as a consequence of Christianity's own inherent weakness, he was the first western historian not to devote much space to estimating evangelistic accomplishments.

While they did not revise Boxer and Elison, historians of the 1990s developed or summarised the oriental and western scholarships. For example, focusing on specific missionaries, Joseph F. Moran's (19372005) treatise on Father Alessandro Valignano should be noted. Concerning the authors of more extensive works, one should mention Andrew C. Ross (1931-2008) and Neil Fujita (1934-). Ross outlined the whole Japanese mission in an heroic approach focussing on leading Jesuit priests in Japan. Bilingual in Japanese and English, Fujita wrote another version of Boxer's history of the Christian century in Japan, by including more academic discoveries that had been made since the midtwentieth century. ${ }^{16}$

There have been two major trends of western historical investigation in the field of Jesuit missions. One has been to discover hidden material and edit hand-written texts in print. The other has been to analyse incidents and synthesise a new theory by reinterpreting the newlydiscovered and edited sources. These trends were shared by Japaneselanguage historians.

\section{Japanese Historians from the Twentieth Century to the Present}

Japanese historians who studied the Christian mission form the fifth historiographical category. They began their investigations in the late nineteenth century simultaneously with the revival of Christian missions to Meiji Japan. Twentieth-century Japanese approaches to missionary history were developed mainly to understand evangelisation within the context of Japanese history rather than as mere incidents within the Christian church. There were, however, two problems in pursuing the topic from a Japanese point of view. One was that the

Bardwell L. Smith (eds.), Warlords, Artists, and Commoners: Japan in the Sixteenth Century (Honolulu: University of Hawaii Press, 1981).

${ }^{16}$ J. F. Moran, The Japanese and the Jesuits: Alessandro Valignano in SixteenthCentury Japan (London: Routledge, 1993); Andrew C. Ross, A Vision Betrayed: The Jesuits in Japan and China, 1542-1742 (Edinburgh: Edinburgh University Press, 1994); Neil S. Fujita, Japan's Encounter with Christianity (New York \& Mahwah, NJ: Paulist Press, 1991). Fujita is fully discussed in the fifth historiographical category. 
source material of the Japanese mission was scattered internationally; and the other was that the documents in Japan had been lost or destroyed during the three-century proscription of the Christian faith.

The initial task of historians was thus to find fragments of evidence and to compile them into a manageable form. While the source study of the Japanese missions was pursued by ecclesiastical historians in Europe, Murakami Naojirô (1868-1966), Okamoto Yoshitomo (1900-1972) and Matsuda Kiichi (1921-1997) contributed to the discovery of remaining Japanese sources as well as to the introduction of European material to Japanese readers. To begin with, Murakami edited or translated Jesuit correspondence, the journals of the Dutch commercial factory in Japan and other western documents. ${ }^{17} \mathrm{He}$ compiled the correspondence between Japanese authorities and representatives of other nations. ${ }^{18}$ Also, he edited the documents written by Englishmen in feudal Japan, as well as the journals of the English commercial factory in Japan. ${ }^{19}$ Murakami was followed by Okamoto Yoshitomo, who edited and published several missionary manuscript sources. ${ }^{20}$ More recently, since the 1990s, the Historical Source Institute of the University of Tokyo has undertaken an on-going compilation of the Jesuit correspondence, in the original European language and in Japanese translation. ${ }^{21}$

${ }^{17}$ Murakami published the following edited monographs: Ikoku nisshishô (Tokyo: Sanshûsha, 1911); Yasokai nenpô (Nagasaki: Nagasaki shiyakusho, 1926); Yasokai Nippon tsûshin: Keikihen (Tokyo: Sunnansha, 1927-28); Ikoku nikkishô (Tokyo: Sunnansha, 1929); Yasokai Nippon tsûshin: Bungo hen (Tokyo: Teikoku kyoikukai, 1936); Deshima rankan nisshi (3 vols., Tokyo: Bunmei kyokai, 1938-39); Yasokai no Nippon nenpô (2 vols., Tokyo: Takubundô, 1943); Nagasaki Oranda shôkan no nikki (3 vols. Tokyo: Iwanami shoten, 1956-58).

${ }^{18}$ Murakami Naojirô (trans.), Ikoku ôfuku shokanshû (Tokyo: Sunnansha, 1929).

19 Murakami Naojirô \& Murakawa Kengo (eds.), Letters Written by English Residents in Japan, 1611-1623 (Tokyo, 1900); Murakami Naojirô (ed.), Diary of Richard Cocks, Cape-Merchant in the English Factory in Japan, 1615-1622, with Correspondence (Tokyo, 1899).

${ }_{20}$ He edited and translated Frois's report on the First Japanese embassy to Europe under Valignano: Okamoto Yoshitomo et al (eds.), La première Ambassade du Japon en Europe, 1582-1592 (Tokyo: Université Sophia, 1942) and Okamoto Yoshitomo (trans.), Kyushu sankô ken'ô shisetsu kôki (Tokyo: Tôyôdô, 1942). He co-edited Segunda parte da Historia de Japam que trata das couzas, que socedarão nesta V. Provincia da Hera de 1578 por diante, começãdo pela conversão del rey de Bungo (1578-1582) (Tokyo: Edição da Sociedade Luso-Japonesa, 1938). He was also the editor of El Nippon y Philipinas sus Relaciones Historicos (Tokyo: Japan Times, 1945). As for Japanese material, he was the editor of Gyosonki (Tokyo: Tôyôdô, 1946).

${ }^{21}$ Tokyo daigaku shiryô hensanjo, Nippon kankei kaigai shiryô: Iezusukai Nippon shokanshî (6 vols. as of 2007, Tokyo: Tokyo daigaku shiryô hensanjo, 1990-). 
Another linguistic expert was Matsuda Kiichi, who was the pioneer of the study of post-war sources on the Christian missions. Although not a Jesuit, he completed university education in 1944 at Jesuit Sophia University, where he met Professor Laures. Matsuda's documentary studies of European-Japanese relations include a report on the documents discovered inside Japanese folding screens at Evora, Portugal; a bibliographical catalogue of European-Japanese international relations; a source study of Japan-related documents in European collections, along with other works, all published in the 1960s. ${ }^{22}$ His Japanese translations of unpublished source material of the Jesuits include Historia de Iapam and the comparative cultural discussion of Japan, both by Luis Frois; Alessandro Valignano's reports to on the Japanese church; and also Carta annua de Japão of the Society of Jesus, all of which were published in the last thirty years of the twentieth century. ${ }^{23}$ His publications encompass several monographs on specific but essential aspects of the Japanese missions. ${ }^{24}$

Based on these extensive source studies, twentieth-century Japanese research of the Jesuit mission developed mainly to understand evangelisation as episodes of Japanese history rather than as part of the growth and decline of the Christian church. Leading scholars in this field are Anesaki Masaharu (1873-1949), Okamoto Yoshitomo, Okada Akio (1907-82), Ebisawa Arimichi (1910-1992), Shimizu Hirokazu (1942-), Takase Kôichirô (1936-) and Neil S. Fujita (1934-), among others. Ane-

${ }^{22}$ Ebisawa Arimichi \& Matsuda Kiichi, Porutogaru evora shinshutsu byôbu monjo no kenkŷ̀ (Tokyo: Natsumesha, 1963); Matsuda Kiichi, Nichiô kôshôshi bunken mokuroku (Tokyo: Keibundo \& Isseido, 1965), and Kinsei shoki Nippon kankei nanban shiryô no kenkyû (Tokyo: Kazama shobô, 1967). In addition, he wrote Nanban shiryô no hakken: Yomigaeru Nobunaga jidai (Tokyo: Chuô kôronsha, 1964).

${ }^{23}$ Matsuda Kiichi \& Kawasaki Momota (trans.), Furoisu Nipponshi (Tokyo: Chuô kôronsha, 1977-80); Matsuda Kiichi \& Engelbert Jorisßen (trans.), Frois no Nippon oboegaki: Nippon to Yôroppa no fûsh û no chigai (Tokyo: Chuô kôronsha, 1983); Matsuda Kiichi et al (trans.), Nippon junsatsuki (1965, Tokyo: Heibonsha, 1973); and Matsuda Kiichi (ed.), Jûroku-shichi seiki Iezusukai Nippon hôkokushû (17 vols., Kyoto: Dôhôsha, 1987-2000.); Matsuda Kiichi et al. (eds. \& trans.) Nippon kankei Iezusukai genbunsho (Kyoto: Dôhôsha, 1987)

${ }^{24}$ E.g. Matsuda, Kirishitan kenkyû (vol. I, Tokyo: Sôgensha 1953; vol. II, Tokyo: Kazama shobô, 1975); Nippo kôshôshi (1955, Tokyo: Kyôbunkan, 1963), Taikô to gaikô (Tokyo: Tôgensha, 1966); Nanban junrei (Tokyo: Asahi shinbunsha, 1967); Keichô shisetsu: Nipponjin hatsu no taiheiyô ôdan (Tokyo: Shin jinbutsu ôraisha, 1969); Hideyoshi no nanban gaikô: San Feripegô jiken (Tokyo: Shin jinbutsu ôraisha, 1972); Shitan tenshô ken'ô shisetu (Tokyo: Kôdan-sha, 1977); and Ômura Sumitada-den (1955, 3rd ed., Tokyo: Kyôbun-kan, 1978). 
saki Masaharu was a pioneer who considered the Christian mission from both European and Japanese viewpoints.

Anesaki applied a cultural approach to European-Japanese relations. He considered two ideas: first, the influence of the Christian mission upon the Japanese nation; and second, the negative effect on national growth of the Tokugawa authorities' ban of Christianity. In independent monographs, he considered five main aspects of the mission: the concealment of converts; the termination of missions; personal spiritual achievements; religious literature; and missionary activity itself. ${ }^{25}$ His Kirishitan dendô no kôhai deals with the rise and fall of the Catholic missions in Japan from 1549 to 1668. In this work, the mission's positive and negative influences on the Japanese rulers and ordinary people became his main concerns. On the Japanese authorities' initially positive and later negative response to the missions, he concluded that the Japanese central court suppressed anything in its way when the church gradually became an obstacle to its rule. Another clue was the church's philanthropy, which helped Jesuits gain converts among ordinary people by using the support of wealthy, influential Christian supporters. Because of anti-Christian persecutions, the missionary church was no longer able to finance the philanthropy necessary to maintain the congregation.

A less cultural and more political and economic approach to the same international relations can be found in Okamoto Yoshitomo. He analysed the triangular relationship among Portuguese traders, missionaries, and Japanese rulers. As a specialist on the relationship between European visitors and Japanese residents, he emphasised the leading diplomatic rôle of the Jesuit missionaries in the Portuguese trade with Japanese merchants, who were closely connected with local lords. He described the Jesuits as diplomats who took advantage of international trade to enhance their church; and he affirmed that the feudal lords had no choice but to welcome Christian missions in order to invite Portuguese ships to their own ports, even if they wanted no evangelisation in their territories. ${ }^{26}$

Another approach to missionary activity rather than the mission itself was made by Okada Akio, an archivist at the Institute of Historical

${ }_{25}$ Anesaki Masaharu, Kirishitan shûmon no hakugai to senpuku (Tokyo: Dôbunkan, 1925); Kirishitan kinsei no shûmatsu (Tokyo: Dôbunkan, 1926); Kirishitan hakugaishich $\hat{u}$ no jinbutsu jiseki (Tokyo: Dôbunkan, 1930); Kirishitan shûkyô bungaku (Dôbunkan, 1932); and Kirishitan dendô no kôhai (Tokyo: Dôbunkan, 1930).

${ }^{26}$ Okamoto Yoshitomo, Jûroku seiki Nichi-Ô kôtsûshi no kenkyû (Tokyo: Kôbunsô, 1936). 
Sources, the University of Tokyo. While consulting the Jesuit documents, he was one of those rare individuals who were not governed by them. With no apparent appraisal of the missionary efforts, he attempted to grasp the meaning of the missions and foreign intercourse in the light of Japanese society. His interest grew to include the western influence on life in Japan and the problems of cultural importation faced by the Christian converts. According to Okada, the Jesuit mission caused two social frictions: first a conflict between non-Christian feudal lords and the Christian God as the target for loyalty; and then withdrawal from social activities, many of them associated with traditional autochthonous customs, which the missionaries considered pagan. He affirmed that most proselytes simply replaced Japanese objects of worship with the Christian God while retaining the conventional framework of Japanese spiritual customs. ${ }^{27}$

In contrast to Okada's thematic writings, Ebisawa Arimichi made more extensive analyses. He regarded the Japanese church as a community of both missionaries and numerous converts rather than as the mere organisation of European priests. From his strict Protestant standpoint, the conflict was between feudal authorities and Christian communities, and not simply political tension between the top rulers and the missionaries. ${ }^{28}$

In Ebisawa's Japanese history of Christians, the Christian mission had two special meanings apart from its attempt to Christianise pagans. According to this analysis, the mission introduced Japan to a new world view, which stimulated an awakening of self, as well as a new rational or scientific reasoning and a positive or critical spirit. In other words, Ebisawa gave Christianity credit for spiritually accelerating the development of Japan's national identity. Also, the qualification for being a Christian in Japan, he claims, consisted simply in recognising the person of God and claiming to deny conventional beliefs, for the Jesuits were linguistically incapable of making their congregation understand fully the true faith. One basis for his assertion lay in the Jesuit publications of

${ }^{27}$ Okada Akio, Nanban shûzokukô (Tokyo: Tajin shokan, 1942). His main articles are compiled into Okada Akio chosakushû (ed. Kodama Kôta, 6 vols., Tokyo: Shibun kaku, 1983-84).

${ }^{28}$ Ebisawa Arimichi, Nippon kirishitanshi (Tokyo: Hanawa shobô, 1966); and Kirishitan no dan'atsu to teikô (Tokyo: Yûzan kaku, 1981). 
Japanese-language catechisms and the doctrine books, which were full of confusing Buddhist and Confucian terms. ${ }^{29}$

After Ebisawa, one discerns two major trends in the Japanese perspectives on the missions. The first is to view the history of the evangelistic activity from the standpoint of its growing conflict with conservative autochthonous institutions. Within the context of Japanese politics, this school, whose members include Murai Sanae (1946-), Shimizu Hirokazu (1942-) and Gonoi Takashi (1941-), discussed how missionaries were expelled and Christians were suppressed by the growing power of the central rulers. ${ }^{30}$ Shimizu Hirokazu, for instance, focussed on the reaction of the Toyotomi and Tokugawa clans against the European enterprise in Japan. His history of Christian proscription ${ }^{31}$ investigates the mission from a strictly Japanese standpoint, employing domestic sources and printed foreign documents in order to examine the cause behind the Japanese authorities' decision to prohibit Christianity and to expel European missionaries. His focus is on the domestic political powers rather than on the mission itself. Based on his premise that Christianity was destined to be expelled from the country, he attempted to find all possible reasons for this within national policies.

The second school of writers, which discussed the mission from the viewpoint of European colonisation, includes Takase Kôichirô (1936-), Neil S. Fujita (1934-) and Takahashi Hirofumi (1960-). ${ }^{32}$ While Shimizu emphasised internal political attitudes, Takase Kôichirô, in his study of the Japanese Christian century, examined the Jesuit mission in the light of the international relationships involving Iberians and Japanese. Working on a global scale that emphasised Japan's conflict with Iberian colonies in the Pacific Ocean, he examined the secular activities of the Society of Jesus, including finance, trade and military affairs. The Jesuits, in his opinion, were also merchants and potent military invaders. The mission was not only excluded by the political power but it also

${ }^{29}$ Ebisawa, Nippon kirishitanshi, 23-37 \& 92-119.

${ }_{30}$ Murai Sanae, Bakuhan taisei to kirishitan kinsei (Tokyo: Bunken shuppan, 1987); Murai, Kirishitan kinsei to minshû no shûkyô (Tokyo: Yamakawa shuppan-sha, 2002); Gonoi Takashi, Nippon kirisutokyôshi (Tokyo: Yoshikawa kôbunkan, 1990); Gonoi, Tokugawa shoki kirishitan kenkyûu (1983, rev ed. Tokyo: Yoshikawa kôbunkan, 1992); and Shimizu Hirokazu, Kirishitan kinseishi (Tokyo: Kyôikusha, 1981); Shimizu, Shokuhô seiken to kirishitan (Tokyo: Iwata shoin, 2001).

${ }^{31}$ Shimizu, Kirishitan kinseishi (1981).

32 Takase Kôichirô, Kirishitan jidai no kenkŷu (Tokyo: Iwanami shoten, 1977); Neil S. Fujita, Japan's Encounter with Christianity (Mahwah, NJ: Paulist Press, 1991); and Takahashi Hirofumi, Iezusukai-no sekai senryaku (Tokyo: Kôdansha, 2006). 
destroyed itself when priests became too absorbed in secular concerns. He maintains that the Iberian trade and the Jesuit mission ultimately shared the same fate, since the priests were involved both officially and privately in commerce.

Neil S. Fujita's Japan's Encounter with Christianity, published in 1991, is an introductory monograph for non-academic readers and contains few source citations. He synthesised previous interpretations, using both European and Japanese sources in order to produce a more plausible perspective on the mission than earlier writers had done. Although his emphasis was on the Japanese religious mentality, he also focussed on how the Christian mission had failed in Japan despite its initial success. He also pointed to the cultural, ethnological and psychological factors of the Japanese people, concluding that the pre-modern Japanese spiritual tradition was alien to the Christian mentality with God at its heart.

A more recent approach among this second trend can be found in Takahashi Hironobu's Iezusukai-no sekai senryaku (2006). Although this title meant the global strategy of the Society of Jesus, the monograph was on the growth of the Portuguese Jesuit mission to India and Japan, under the leadership of Father Valignano during the fourth quarter of the sixteenth century. By illustrating the development of the Society's military characteristics, Takahashi discussed that the Jesuit priests conceived Japan to be an object for Portuguese military invasion just as earnestly as to be a new evangelistic field. This perspective is worthwhile, since Takahashi's argument was not so much based on a Japan-centred framework as based on a more extensive framework of the Portuguese Jesuit mission, which began in Europe and expanded to Japan.

Not surprisingly western and Japanese academics have almost always differed in their interpretations. Western historians endeavoured to define the story of the missions in the context of the Japanese church, which negotiated with the Japanese authorities. Western historians have measured missionary success in terms of the number of converts. They have also tried to find the causes of religious oppression in the various motives of rulers. On the other hand, Japanese historians have generally tried to seek meaning, for Japanese society, in missionary activities. Even those who dealt with missionary accomplishments were more interested in cultural influence on a traditional society than in the number of converts. When they examined the reasons for official persecution, they attempted to grasp the overall political and economic intentions of successive rulers rather than to analyse each daimyô's actions. One could therefore say that the study of the 
Jesuit missions finally found a place in Japanese history when Japanese historians clarified the meanings of the missionary enterprise for the nation.

\section{B. Historiography of the Jesuit Mission to New France}

The historiography of the Jesuit missionary work in New France can be divided into six main categories. In the first category is one study, published in France in the eighteenth century. The second and third groups include French- and English-language histories in the nineteenth and early twentieth centuries. In the fourth and fifth categories, one finds secular scholarship and ecclesiastical accounts, from the earlier twentieth century to the present.

\section{The Eighteenth Century}

In the first category is a history of the early Jesuit mission in New France that is based on the documents written by explorers and missionaries in the seventeenth century. The author of this history of New France was Pierre-François-Xavier de Charlevoix, SJ (1682-1761), who moved beyond mere documentation of the Jesuits into analytical narrative, and thus his history, published in 1744, remains useful today. Charlevoix was admired by later historians for sound sourcebased descriptions covering global aspects of French colonial history from the discovery and exploration in the early sixteenth-century to the colonial rivalries of the early and mid-eighteenth century. ${ }^{33}$

As for his accounts of the Jesuit mission, however, his writing is primarily a summary of the evolution of ecclesiastical institutions and practices. Throughout his accounts of the period from the 1620s through the 1650s, Charlevoix kept close track of missionary progress among the Huron and neighbouring tribes. He applauded both the efforts of missionaries and the strong faith of native converts. Every incident that happened in the Huron missions was interpreted as helpful to the growth of Christianity in New France. From the standpoint of the benefits of French colonisation, he made an important contrast between the

${ }^{33}$ Pierre-Francois-Xavier de Charlevoix, SJ, Histoire et description générale de la Nouvelle France, avec Le journal historique d'un voyage fait par ordre du roi dans l'Amérique septentrionale (3 vols., Paris: Didot, 1744). 
virtuous Hurons, allied with the French, and the vicious Iroquois, who attacked the French colonies. This dualistic perspective on the native North American peoples was picked up and perpetuated by nineteenthcentury historians.

\section{French-language Histories in the Nineteenth and Early Twentieth Centuries}

The second and third historiographical categories include studies of New France during the nineteenth and early twentieth centuries published in France or in North America. These works were written by a wide assortment of authors, including secular French Canadians, Jesuits and other priests, as well as anglophone North Americans. In the French-language, to begin with, the influential writers included François-Xavier Garneau (1809-66), Benjamin Sulte (1841-1923), Jean-Baptiste-Antoine Ferland (1805-65), Étienne-Michel Faillon (ca.1799-1870) and Camille de Rochemonteix (1834-1923).

François-Xavier Garneau, born in Lower Canada (now part of Quebec), was a French-Canadian nationalist. His Histoire du Canada depuis sa découverte jusqu'à nos jours was first published in $1845 .{ }^{34} \mathrm{In}$ it, he argued that the Jesuit missions had retarded the development of the colony and nineteenth-century liberalism. His anti-clerical attitude provoked proclerical reproaches from conservative francophone readers. Although he regarded Charlevoix as the best early historian of Canada because of his exact and minute descriptions as well as his simple and natural style, he considered Charlevoix's ecclesiastical view of the colony outdated and irrelevant for contemporary readers living under British rule. Garneau dismissed missionary enterprises and experiences. He also neglected the native population, to whom the Jesuits had preached. ${ }^{35}$

Another secular francophone author was Benjamin Sulte, whose extensive publications included his Histoire des Canadiens-français,

\footnotetext{
${ }^{34}$ Garneau, Histoire du Canada depuis sa découverte jusqu'à nos jours (1845, $4^{\mathrm{e}}$ éd., 4 tomes., Montréal: Beauchemin \& Valois, 1882). The first edition of 1845 in three volumes was enlarged to four volumes as the second edition in 1852 . The third edition was published finally as a complete set in 1859 , and was further enlarged as the fourth edition in 1882. An English edition is available as History of Canada, from the Time of Its Discovery till the Union Year 1840-41 (trans. of rev. 1859 ed. by Andrew Bell, 2 vols., Montréal: John Lovell, 1862).

${ }^{35}$ Garneau, History of Canada, vol. I, xx-xxi; Histoire du Canada, vol. I, vi-viii.
} 
$1608-1880 .{ }^{36}$ In recounting events in seventeenth-century Canada, Sulte often referred to Jesuit missionaries critically, mainly through the eyes of French colonists in North America. His condemnation of the Jesuits was demonstrated by his criticism of The Jesuit Relations, in which the missionaries were absorbed in their Christianising activity. Nor was Sulte sympathetic to the Huron nation. Like Garneau, he described what Jesuits and native converts had done against the French settlers. In his opinion, the Jesuits could be appreciated only for their valiant, but impossible and ineffective, mission to the native population which would have been better off if it had become acquainted with the true Christian God.

By contrast, clerical historians admired and emulated Charlevoix's pro-Jesuit point of view. Jean-Baptiste-Antoine Ferland, a Roman Catholic priest in Quebec, interpreted Jesuit activity as one of the grand successes of the French colony. Jesuit missionaries were colonial heroes. To explain the failure of the mission and the dispersal of the Hurons, Ferland resorted to a seventeenth-century Jesuit convention, which interpreted the failure and dispersal as a divine sign that God was displeased with the insufficient outcome. In other words, God permitted the Huron people to join the Christians, and then He decided to abandon these objects of conversion, despite a Jesuit victory over the Hurons. ${ }^{37}$

Along the same line, Étienne-Michel Faillon and Camille de Rochemonteix, SJ, both writing in France, dealt with the missions in terms of the efforts of the French to convert the Huron and other native peoples. These two historians' interest in the Hurons consisted only in showing how the Amerindians were different from Christians and how they could have been converted to lead a Christian life. These authors found it unnecessary to make references to native cultural aspects, such as social structures and dietary habits, which had little to do with Christianisation. Rochemonteix's monograph especially turned out to be no more than an heroic collective biography of missionaries and a chronology of the mission. ${ }^{38}$

${ }^{36}$ Benjamin Sulte, Histoire des Canadiens-français, 1608-1880 (8 vols., Montréal: Wilson, 1882-84). Two other examples of his works are Histoire de la ville des TroisRivières et de ses environs (Montréal: Eusèbe Sénécal, 1870); and La guerre des Iroquois, 1600-1653 (Ottawa: J. Durie; Toronto: Copp Clark, 1897).

${ }^{37}$ Jean-Baptiste Ferland, Cours d'histoire du Canada (2 tomes., Québec: Augustine Côté, 1861-65).

${ }_{38}$ Étienne-Michel Faillon, Histoire de la colonie français en Canada (3 tomes, Villemarie: Bibliothèque Paroissiale, 1865-66); and Camille de Rochemonteix, SJ, Les Jesuites de la Nouvelle-France aux $17^{\text {me }}$ siècle (3 tomes, Paris: Letouzey et Ané, 1895-96). 


\section{English-language Histories in the Nineteenth and Early Twentieth Centuries}

While French-language scholars of the Jesuit mission in Canada were at the forefront, there were several English-speaking historians, who form the third category. Among these historians are William Smith (17691847), John Mercier McMullen (1820-1907), Francis Parkman (182393) and Thomas J. Campbell (1848-1925). Smith and McMullen should be noted for their ignorance of the Jesuit mission. In writing about the same seventeenth- and eighteenth-century Canada that French-language contemporaries dealt with, Smith totally omitted the Jesuit missionary activity from his account. Born in New York and educated in England, Smith was an Anglo-Saxon bureaucrat in Lower Canada, home of the majority of French Canadians. For Smith to keep the peace and to maintain his position as a career civil servant, it was no doubt wise to omit any negative comments on the Jesuits in Lower Canada, lest he should incur the wrath of the overwhelming francophone majority. ${ }^{39}$

Similar omissions can be found in the general history of John M. McMullen, an Irish Canadian in Canada West, now part of Ontario. As in the monograph by Smith, the seventeenth-century under the Jesuit leadership was outside McMullen's academic concerns. Thus, he merely touched on the mission and native peoples in one short passage. In his Anglo-centric version of Canadian history, Canada had progressed by turning its back on fierce native populations to welcome Anglo-Saxon immigrants, who became his main focus. ${ }^{40}$

On the other hand, although he was an Anglophone Protestant, the American historian Francis Parkman treated the Jesuit mission as the central subject of study in his classic The Jesuits in North America in the Seventeenth Century. ${ }^{41}$ There are two significant points in Parkman's

39 William Smith, History of Canada; from Its First Discovery till the Year 1791 (2 vols. Québec: John Neilson, 1815). The first volume has the title History of Canada; from Its First Discovery till the Peace of 1763, but it is altered as above in the second volume. His work did not appear in print immediately and became available as late as 1826 . For Smith's socially complicated situation, see J. M. Bumsted, 'William Smith Jr. and The History of Canada', in Lawrence H. Leder (ed.), Loyalist Historians, Vol. I of Colonial Legacy (New York: Harper \& Row, 1971), 182-201; and Bumsted, 'William Smith', Vol. VII of Dictionary of Canadian Biography (1988), 816-19.

${ }^{40}$ John M'Mullen [McMullen], The History of Canada from Its First Discovery to the Present (Brockville, C. W.: J. M’Mullen [McMullen], 1855), pp. xiv \& 31. The book was revised and enlarged in 1867 and 1892.

${ }^{41}$ Francis Parkman, The Jesuits in North America in the Seventeenth Century (1867, Williamstown, Massachusetts: Corner House, 1980). 
work of 1867. First, it is a pioneer English-language study of Jesuit influence among native peoples. Second, he was also the first historian to use a biographical approach to the French missions. This biographical style would be followed by his contemporary Jesuit historians, such as Rochemonteix in France and Campbell in the United States.

Parkman discussed the Jesuit mission through the biographies of Jesuit priests, who became his protagonists. His focus was on the missionary undertakings among the Huron and other native peoples until the dispersion of the Huron nation in 1649. He applauded the Jesuits for their achievements among native people, and praised the native converts in terms of both their number and spirituality. At the same time, he did not agree with the Jesuits' view of life, which was totally dominated by God. Instead, he criticised them from the perspective of Unitarian humanism. This critical attitude could be explained by his background. He was an American, with little connection to Canadian society. Nor was he a priest. It was only his academic interest in colonial North America that connected him with New France.

Towards the end of the nineteenth century there was a dramatic change in research on the Jesuit mission. From 1896 to 1901, thirty years after Parkman, the English translation of the Jesuit missionary correspondence was produced by Reuben Gold Thwaites, with the help of others. ${ }^{42}$ Consequently English-speaking historians such as Thomas J. Campbell, SJ (1848-1925), had easy access to the Jesuit correspondence.

Campbell published Pioneer Priests of North America, 1642-1710 in 1908 and The Jesuits, 1534-1921 in 1921. ${ }^{43}$ His approach in the first book is a hybrid blend of secular American historians such as Parkman and the ecclesiastical work of priests like Ferland or Rochemonteix. Campbell's publication is a collective biography of the North American Jesuit missionaries among the Amerindians who lived in the Valley of the Saint Lawrence. Missionary activity was reconstructed by tracing the

${ }^{42}$ Reuben Gold Thwaites et al (eds.), The Jesuit Relations and Allied Documents: Travels and Explorations of the Jesuit Missionaries in New France, 1610-1791 (73 vols., Cleveland: Burrows Brothers, 1896-1901).

${ }_{43}$ Thomas J. Campbell, Pioneer Priests of North America, 1642-1710 (3 vols. New York: The America Press, 1908-1911), whose sequel is Pioneer Laymen of North America (New York: The American Press, 1915). As a Jesuit, Campbell's continuing interest in Jesuit missionary activities produced the following books: Out of the Grave: The Discovery of Fort St. Charles in 1908 (St. Boniface, Manitoba, 1915); The Jesuits, 1534-1921: A History of the Society of Jesus from Its Foundation to the Present Time (New York: The Encyclopedia Press, 1921); and The Martyrs of the Mohawk (Apostleship of Prayer, 1926). 
efforts of the Jesuit fathers. Campbell used the contents of the missionary reports relatively faithfully and uncritically, exercising judgement only in determining which part of the reports to select in order to narrate the story. His work, unlike Parkman's, represents almost no change from seventeenth-century Jesuit documents in the interpretation of either Amerindians or mission.

The other monograph by Campbell is a general history of the Society of Jesus. It deals briefly with both missions, in New France and in Japan, along with other missions throughout the world. Nevertheless, he deals with the two missions in separate chapters as if they were unrelated with each other.

\section{Secular Scholarship in the Twentieth Century}

After the first quarter of the twentieth century, the historical study of the earlier French mission experienced a turning point. In the 1920s, archaeologists and anthropologists undertook research on the historic native peoples. The indigenous peoples along the Saint Lawrence became the subjects of academic investigation and, gradually, an attempt was made to overcome embedded national or religious biases that had been a characteristic of many previous histories of the Jesuit mission.

Among the archaeological researchers were R. B. Orr, T. F. McIlwraith, R. E. Popham, Wilfrid Jury, Elsie McLeod Jury, J. N. Emerson and Martha A. Latta. As early as 1922, Orr began to research the Hurons. McIlwraith's archaeological team pursued a survey of Huron country in the early 1940s. In 1950, Popham endeavoured to identify the historical geography of the Huron nation. The former Jesuit mission sites of Sainte-Marie and Saint-Louis were investigated by Kenneth E. Kidd in the 1940s and by Wilfrid Jury and Elsie McLeod Jury in the 1950s. In the 1960s, Emerson surveyed the historic Huron site of Cahiagué. In the 1980s, Latta endeavoured to identify the Jesuit mission sites in eastern Huronia. ${ }^{4}$

44 R. B. Orr, 'The Hurons', 33rd Annual Archaeological Report 1921-22, Appendix to the Report of the Minister of Education, Ontario (Toronto, 1922): 9-23; T. F.Mcllwraith et al., 'Archaeological Work in Huronia', The Canadian Historical Review 27 (1946): 394-401; R. E. Popham, 'Late Huron Occupations of Ontario: An Archaeological Survey of Innisfil Township', Ontario History 42 (1950): 81-90; Kenneth Earl Kidd, The Excavation of Sainte-Marie I (Toronto: University of Toronto Press, 1949); Wilfred Jury \& Elsie McLeod Jury, Sainte-Marie among the Hurons (Toronto: Oxford University Press, 1954) and Jury \& Jury, Saint Louis: Huron Indian Village and Jesuit Mission Site, University of Western Ontario, Museum of Indian Archaeology, Bulletin No. 10 (London, 
Further work in anthropology and related fields was carried out by Henry Morgan, Diamond Jenness, W. Vernon Kinietz, James V. Wright, Elizabeth Tooker, Conrad E. Heidenreich, John Steckley and Marguerite Tehariolina Vincent. Although Morgan's anthropological classic on the Iroquois, published first in the mid-nineteenth century, does not necessarily belong to this category, because the Iroquois nation was never part of the active Jesuit mission, the frequent reprints of his academic contribution repeatedly stimulated later anthropologists of the twentieth century. Jenness studied the native groups of Canada, and in 1932 published a general guidebook. In 1940, Kinietz focussed on the Huron and Algonquian groups along the Great Lakes and attempted to explain their culture. In 1955, Wright collected the research data of the Iroquoian tribes of the part of New France that is part of today's Ontario, and discussed their cultural development. In 1964, Tooker consulted the accounts of Samuel de Champlain, founder of New France in the early seventeenth century, as well as accounts of missionaries, in order to create Huron ethnography. In the 1960s and 1970s, Heidenreich discussed the historical geography of the Huron country as well as the cultural interaction through trade. In 1982, Steckley re-examined Tooker's article of 1970, on the sociopolitical organisation of Huron clans. Finally, in 1984, Vincent published a synthesis of ethnographic works and available historical data of the Huron nation. ${ }^{45}$

Ontario, 1955); J. N. Emerson, 'Cahiagué 1961', Ontario History 54 (1962): 136-37; and Martha A. Latta, 'Identification of the seventeenth century French Missions in Eastern Huronia', Journal of Canadian Archaeology 9 (1985): 147-71.

${ }^{45}$ Henry Morgan, The League of the Ho-de'-no-sau-nee, Iroquois (Rochester: Sage \& Brother; New York: Mark H. Newman; Boston: Gould \& Lincoln, 1851), or The League of the Iroquois (1851, reissue ed., A Citadel Press Book, New York: Carol Publishing Group, 1993); Diamond Jenness, The Indians of Canada (Ottawa: National Museum of Canada, 1932); W. Vernon Kinietz, The Indians of the Western Great Lakes, 1615-1760 (Ann Arbor: U of Michigan P; Rexdale: John Wiley \& Sons Canada, 1940); J. V. Wright, 'The Middleport Horizon', Anthropologica 2 (1960): 113-20; Wright, The Ontario Iroquois Tradition National Museum of Canada Bulletin No. 210, Anthropological Series No. 75 (Ottawa, 1966); Elizabeth Tooker, An Ethnography of the Huron Indians, 16151649, Bureau of American Ethnology Bulletin 190 (Washington, D. C., 1964); Tooker, 'Northern Iroquoian Sociopolitical Organization', American Anthropologist 72 (1970): 90-97; Conrad E. Heidenreich, 'Indian Occupance of Huronia, 1600-1650', in Canada's Changing Geography (ed. R. Louis Gentilcore, Scarborough: Prentice-Hall of Canada, 1967); Heidenreich, Huronia: A History and Geography of the Huron Indians, 1600-1650 (Toronto: McClelland and Stewart, 1971); Conrad E. Heidenreich \& Arthur J. Ray, The Early Fur Trades: A Study in Cultural Interaction (Toronto: McClelland and Stewart, 1976); John Steckley, 'The Clans and Phratries of the Huron', Ontario Archaeology 37 
The above studies developed in parallel with historical works about seventeenth-century Canada. In addition to works of francophone historians, more and more English-speaking scholars in the fourth historiographical category produced works related to the Jesuit missions. This group included Alfred Goldsworthy Bailey (1905-1997), John Hopkins Kennedy, Cornelius J. Jaenen (1927-), Olive Patricia Dickason (1920-), Bruce G. Trigger (1937-) and John Webster Grant (1919-). French-language historians Marcel Trudel (1917-) and Lucien Campeau (1914-2003) should also be noted as representing the fifth category.

The subject of cultural exchange between the French and Amerindians was first introduced by Alfred Goldsworthy Bailey, whose work was a turning point in the historical study of the native Canadian people. The Conflict of European and Eastern Algonkian Cultures, 1504-1700, Bailey's excellent monograph, was published in New Brunswick just prior to the Second World War, and after the War it gradually attracted the attention of North American academic readers. His discussion of the Algonquian peoples is noteworthy as it sets up for the first time an intercultural theme of the native responses to the European colonisation of Canada. ${ }^{46}$

During the years before Bailey's publication was properly appreciated, John Hopkins Kennedy, an American historian, produced a more conventional study entitled Jesuit and Savage in New France. ${ }^{47}$ Kennedy investigated the development of the methods or stages by which the French gradually came to view the Amerindians. Above all, he argued about the French missions in the seventeenth century, all from the point of view of his own period. Rather than discussing the native peoples, he focussed on the images of the indigenous

(1982): 29-34; and Marguerite Tehariolina Vincent, La nation huronne: Son histoire, sa culture, son esprit (avec la collaboration de Pierre H. Savignac, Québec: Éditions du Pelican, 1984).

${ }_{46}$ Alfred Goldsworthy Bailey, The Conflict of European and Eastern Algonkian Cultures, 1504-1700: A Study in Canadian Civilization (1st ed., Saint John: New Brunswick Museum, 1937; 2nd ed., Toronto \& Buffalo: University of Toronto Press, 1969). Because of the limitation of funds, the concluding chapter was published separately, in Bailey, 'Social Revolution in Early Eastern Canada', The Canadian Historical Review 19 (1938): 264-76. Other relevant articles include 'The Significance of the Identity and Disappearance of Laurentian Iroquois', Transactions of the Royal Society of Canada, 3rd series, section II, 28 (1933): 97-108; and 'Social Revolution in Early Eastern Canada', The Canadian Historical Review 19 (1938): 264-76.

${ }^{47}$ John Hopkins Kennedy, Jesuit and Savage in New France (New Haven: Yale University Press, 1950). 
people established through the eyes of those who grew up in European culture. Although his conclusions are not always new, at least he successfully illustrated seventeenth-century missionary views of native peoples. He argued that such notions themselves weakened the evangelistic enterprise in the end. Although his study was squarely in the Eurocentric tradition, it did advance beyond the ethnocentrism of the previous centuries. He saw the misinterpretations of the French, whereas previous historians, or many of them, had worked within those preconceptions.

During the twentieth century, the archaeological and anthropological study of Amerindians in the Saint Lawrence region was firmly established. After Kennedy came Marcel Trudel, who produced abundant works on the colonial period of Canada during his tenure at Laval University, in 1947-1965, and later at the University of Ottawa. Histoire de la Nouvelle-France, his masterpiece, based on accumulated research over forty years, is an attempt at an historical synthesis of the development of the French colony in the sixteenth and seventeenth centuries. ${ }^{48}$

Although he focussed on French-language Quebec, as had Garneau, Ferland and Sulte, Trudel was at least free from ecclesiastical or nationalist views. He never criticised the Jesuit mission in terms of its influence upon the New France church or the francophone population. Instead, the missionary activity is discussed in terms of the failure of the Europeans to dominate the native population. In this light, Trudel evaluated the historical Jesuit mission in terms of how poorly it helped to develop French settlement. He thus maintained only a negative perspective on the missionary activity in the Saint Lawrence region.

The interpretive focus on European colonisation, or what one may today call Eurocentrism, began to be addressed in the work of Cornelius J. Jaenen, who dealt not only with the Amerindian-European relationship, as had Bailey, but also with native education and the Christian church in the colony. ${ }^{49}$ Among his publications, Friend and

${ }^{48}$ Marcel Trudel, Histoire de la Nouvelle-France (3 tomes, Montréal \& Paris: Les éditions Fides, 1963-83).

49 As to the relations between the French and the Amerindians, Jaenen wrote the following: 'Problems of Assimilation in New France, 1603-1645', French Historical Studies 4 (1966): 265-89; 'The Meeting of the French and Amerindian in the Seventeenth Century', Revue de l'Université d'Ottawa 43 (1973): 128-44; 'Amerindian Views of French Culture in the Seventeenth Century', The Canadian Historical Review 55 (1974): 261-91; The French Relationship with the Native Peoples of New France and Acadia (Ottawa: Canadian Government Publishing Centre, 1984); The Role of the Church in New France (Toronto: McGraw-Hill Ryerson, 1976); 'Education for Francisation: the 
Foe of 1976 examines the trend of European-dominated studies of Amerindian-European relations. Among Canadian historians, Bailey was the first to introduce the subject of European domination, but he had focussed solely on the Eastern Algonquian peoples. Other groups in the Great Lakes region, including the Huron and Iroquois nations, were examined by Jaenen, who incorporated modern anthropology and Amerindian-centred study into his work. In this monograph, he emphasised the cultural gap between Europeans and Amerindians, a major contributing factor to the European misperception of the latter. He did not limit his analysis of the Jesuit mission to religious endeavours. Instead, he stressed the cultural interaction between European immigrants and native peoples. ${ }^{50}$

Along the same line, Olive Patricia Dickason discussed French colonisation in terms of French images of the native peoples, as well as intercultural relations based on these images. As one of Jaenen's students, Dickason denied the conventionally-assumed cultural dichotomy in Canada between the 'savage' people without order and the civilised European with order, and instead sought another explanation for the Jesuits' cultural approach to the native population. According to Dickason, the Jesuits intuitively rather than logically built a native Christian church without totally replacing the original culture with Christianity. Through their preaching and teaching about the Christian God, the French missionaries separated their converts socially from traditional communities, thereby disorienting and disorganising native society. Dickason concluded that the Euro-Christian and Amerindian cultures never became one, and thus native culture was never eradicated or even reformed by European cultures. ${ }^{51}$

Another revisionist was Bruce G. Trigger. Among his publications related to the Jesuit mission, three stand out. The first, The Huron: Farmers of the North, published in 1969, is an historical ethnography of the Huron

Case of New France in the Seventeenth Century' in The Legacy, Vol. I of Indian Education in Canada (ed. Jean Barman, Yvonne Hébert \& Don McCaskill, Vancouver: University of British Columbia Press, 1986).

${ }^{50}$ Cornelius J. Jaenen, Friend and Foe: Aspects of the French-Amerindian Cultural contact in the Sixteenth and Seventeenth Centuries (Toronto: McClelland and Stewart, 1976).

${ }^{51}$ Olive P. Dickason, Myth of the Savage and the Beginnings of French Colonialism in the Americas (Edmonton: University of Alberta Press, 1984), 251-278. Dickason is also the author of Canada's First Nations: A History of Founding Peoples from Earliest Times (Toronto: McClelland and Stewart, 1992). 
people that deals with the way they interacted with nature, and with each other in large social units. Trigger argued that in order to understand a culture, one has to know how that culture developed. Seven years later, in 1976, he completed The Children of Aataentsic, which was an attempt to cast aside the European-dominated trend of native historical study. In addition, he attempted to understand Huron mentality by recreating pre-contact culture, then comparing it to the culture that developed during European-Amerindian interactions. The historiographical significance in these two publications is that he paid much more attention to the Huron nation than previous scholars had done, analysing not only the French-Amerindian relations but also Huron society itself. He consulted sources written by seventeenth-century French missionaries and explorers in order to gain a deeper understanding of native society. His attempts were limited by the lack of sources on the native side, and thus he was often obliged to rely on archaeological studies with their necessarily limited evidence. Trigger's third influential monograph, Natives and Newcomers, was published in 1984. It examines the relations between French and Amerindians in the sixteenth and seventeenth centuries. In this iconoclastic study, he went beyond explorers and priests as heroic figures during the two centuries of colonisation, paying equal attention to traders and lay missionary assistants. ${ }^{52}$

\section{Ecclesiastical Contribution in the Twentieth Century}

Another group, modern ecclesiastical historians, constitute the fifth category. They continued to discuss seventeenth-century Jesuit missions, seeking to reconcile their sympathy for missionary activity with a recognition of its cultural biases. Such clerical historians include John Webster Grant, a United Church clergyman in Ontario, and Lucien Campeau, SJ, in Quebec. In the Moon of Wintertime, ${ }^{53}$ Grant described the encounter of European Christians with native people from the colonial period until the twentieth century. Unlike Dickason or Jaenen, Grant considered the Christian evangelisation as an

${ }^{52}$ Bruce G. Trigger, The Huron: Farmers of the North (1st ed., New York: Holt, 1969; rev. ed. Toronto: University of Toronto Press, 1990); Trigger, Children of Aataentsic: A History of the Huron People to 1660 (Kingston \& Montréal: McGill-Queen's University Press, 1976); and Trigger, Natives and Newcomers: Canada's "Heroic Age" Reconsidered (Kingston \& Montreal: McGill-Queen's University Press, 1985).

${ }_{53}$ John Webster Grant, Moon of Wintertime: Missionaries and the Indians of Canada in Encounter since 1534 (Toronto: University of Toronto Press, 1984). 
enterprise to impose Christian beliefs and values on indigenous people without appreciating their culture. Thus, Grant's conclusions are similar to Parkman's, though unlike the American historian, Grant insisted that the mission had a limited effect upon native socio-economic patterns. Like Parkman, Grant evaluated the fervour and commitment of native converts, and concluded that they merely changed their economic or social behaviour without assimilating Christian values.

Unlike Grant's general ecclesiastical history, Lucien Campeau's histories concentrate on the Jesuit mission itself. His thorough, source-based study has produced several monographs. ${ }^{54}$ In La mission des Jésuites chez les Hurons, 1634-1650, published in 1987, Campeau focussed on how the missionaries christened the Huron people. His aim in this monograph was to challenge Trigger's thesis, in Children of Aataentsic, that the main reason for the political destruction of the Huron nation was the cultural shock caused by Jesuit contact. Although presenting few clear antitheses, Campeau implied that the militarily powerful Iroquois, and not the Jesuits, were solely responsible for the destruction of the Huron confederacy. Also, like ecclesiastical historians of the previous centuries, Campeau celebrated Jesuit accomplishments in converting indigenous people to Christianity. What is different from his predecessors is that he did not describe missionaries as heroic, instead treating them collectively as an evangelistic corporation.

A more significant contribution by Campeau is his compilation of Jesuit correspondence, entitled Monumenta Novae Franciae..$^{55}$ Here, he brought to light handwritten letters that had been preserved in manuscript form for more than three centuries at the Jesuit archives in Rome. Because he did not publish the manuscripts with general readers in mind, all the letters were simply transcribed into print in their original languages. Without his editorial efforts, however, few students would have had access to Jesuit documents beyond Thwaite's edition of The Jesuit Relations, published in 1896-1901.

${ }^{54}$ Lucien Campeau, SJ, La première mission d'Acadie (1602-1616) (Roma: Monumenta Historica S. I.; Québec: les Presses de l'Université Laval, 1968.); Campeau, La première mission des Jésuites en Nouvelle-France, 1611-1613 (Montréal: Bellarmin, 1972); and Campeau, La mission des Jésuites chez les Hurons, 1634-1650 (Vol. XLVI de Bibliotheca Instituti Historici S. I., Montréal: Bellarmin; Roma: Institutum Historicum S. I., 1987).

${ }^{55}$ Lucien Campeau, SJ (ed.), Monumenta Novae Franciae (9 vols., Roma: Institutum Historicum Societas Iesu; \& Montréal: Bellarmin; or Québec: l'Uviversité Laval, 1967-2003). 


\section{Recent Scholarship}

More recent, and perhaps too new to fully identify their historiographical significance, are the publications by Dominique Deslandres, Karen Anderson, Carole Blackburn and Nicholas P. Cushner. ${ }^{56}$ In her Croire et faire croire of 2003, Deslandres dealt with the French missionary activity from a perspective different from the French colonialism of North America. By focussing on the European origins of the evangelists, she examined the historical significance of the New France mission in the context of more extensive ecclesiastical French religious restoration beyond North America.

The underlying themes of Anderson's Chain Her by One Foot of 1991, and Blackburn's Harvest of Souls of 2000 were missionary successes and failures in subjugating native peoples. Within the framework of gender-related acculturation, Anderson affirmed that the Jesuit missionaries had transformed native society, which was based on gender-equality, into a patriarchy by imposing European paternal cultural values on Amerindians. By contrast, Blackburn applied a rhetorical analysis to The Jesuit Relations in her endeavour to prove the Jesuits' failure in colonising native people under their European authority, despite their claims of evangelistic accomplishments in their Relations. According to Blackburn, the Hurons wilfully accepted Jesuit messages and teachings in a way advantageous to themselves, and subverted the evangelistic intent of the missionaries, along with their European authority.

More polemical is Cushner's Why Have you Come Here?, whose discussion entails the entire missionary activities in the Americas. Objecting to modern cultural anthropologists' idea that one belief system cannot replace another, Cushner considers how successfully Jesuit evangelists replaced native American religion with Christianity. His unspoken premise is that Amerindian peoples had a religious system fully compatible with Christianity, which he remains to prove. $\mathrm{He}$

${ }^{56}$ Dominique Deslandres, Croire et faire croire: Les missions française au XVIIe siécle (1600-1650) (Paris, Fayard, 2003; Karen Anderson, Chain Her by One Foot: The Subjugation of Women in Seventeenth-Century New France (London \& New York: Routledge, 1991); Carole Blackburn, Harvest of Souls: The Jesuit Mission and Colonialism in North America, 1632-1650 (Montreal \& Kingston: McGill-Queen's University Press, 2000); and Nicholas P. Cushner, Why Have You Come Here? (New York: Oxford University Press, 2006). 
contends that the replacement process was incomplete and yet effective enough to 'ensure a lasting foothold'..$^{57}$

\section{Towards a Synthesis of Historiographies}

Within the framework of historical analysis, one can view clear differences and similarities. On the one hand, the Iberian missionary studies of Japan take into account only the missionary church with no consideration of the entire Japanese nation. On the other hand, the colonial French studies largely discuss the growth of a European colony; and with it, the native church. In terms of ethnicity, western historians discussed the Christian mission within the concept of the missionary church or the European colony while Japanese authors illustrated the mission within Japanese society or the foreign relations of Asia. In general, most western scholars have not considered seriously the development of the non-Christian nations, in Canada and in Japan.

There is one example of French colonial interpretations that should be reinterpreted from a broader international perspective. Affirming that the missionary martyrs in the 1640 s were rhetorical fictions of The Jesuit Relations, Guy Laflèche ascribes the myths to the personal initiatives of missionary correspondents like Fathers François le Mercier and Jérôme Lalemant. Laflèche implicitly assumes that they were personally responsible for creating the 'spirituality', or the aura, of martyrdom, which was, in effect, foreign to the Ignatian spirituality. This may be the most plausible interpretation that could be gleaned from the reports from New France. ${ }^{58}$ Nevertheless, a further consideration of the contemporary Jesuit publications back in France will prove that Le Mercier and Lalemant do not deserve such an indictment. It was rather the Jesuit order, back in France of the early seventeenth century, that began to include martyrdom in its publications. When Jesuits experienced numerous executions of missionaries and converts in Japan during the first half of the seventeenth century, the Society of Jesus published the French translations of Iberian accounts that dealt

57 Cushner, op. cit., 3 \& 198.

58 Guy Laflèche, 'Les Jésuites de la Nouvelle-France et le mythe de leurs martyrs', Les Jésuites parmi les hommes aux XVI et XVII siècles: Actes du Colloque de ClermontFerrand (avril 1985) (ed. G. et G. Demerson, B. Dompnier et A. Regond, n.p. (France): Associations des Publications de la Faculté des Lettres et Sciences Humaines de Clermont-Ferrand, 1987), 35-45. 
with their deaths as martyrs. Before Le Mercier and Lalemant took charge of the reports on New France, they were simply trained back in France during the very decades when the martyrdom in Japan was one of the main themes for the French Jesuit publications. ${ }^{59}$ Therefore, the correspondents from New France never created or initiated the rhetoric of martyrdom.

A summary of academic contributions in the two geographic fields brings to light some neglected international considerations as well as some important clues for further investigation. The historiography of the French Jesuits and that of the Iberian Jesuits have been divorced from each other. Historians in one field are ignorant of historians in the other. In the case of Japan, non-western historical documentation and perspectives do not match the solely western historical observations and interpretations. A historian of the French Jesuits should realise the characteristics of each document and work out the cultural influence on its contents. Thus, from an international standpoint, there still seems to be room for revisions or even for unexpected perspectives on the French Jesuit mission, to be discussed fully in succeeding chapters.

${ }^{59}$ See appendix 1. 
Takao Abé - 978-90-04-20965-7 Downloaded from Brill.comఠ4/26/2023 02:17:13PM via free access 


\section{INTERPRETING NON-CHRISTIAN CULTURES: JESUIT BIASES}

Historians today agree that the Jesuit interpretation of foreign nations was biased and needs to be treated carefully. In Canadian historiography, for example, there remain three questions on the Jesuit observations of native peoples and their culture. First, in what way and at what points are the Jesuit observations about the First Nations wrong and distorted? Second, given that the European missionaries were prejudiced in their interpretations, what were their biases and mistakes? Third, what are the alternative explanations of the non-Christian cultures, based on the answers to these two earlier questions?

Answering these questions is not an easy task, for the lack of written indigenous documents has forced scholars to revise missionary interpretations by relying on speculation, albeit cautious speculation. It is also well known to scholars who have studied human psychology that understanding by analogy will always be the first approach to a newlyencountered, foreign culture. Given the absence of counter-evidence from the voiceless indigenous peoples, one may find it difficult to identify the European or Christian biases and errors in one-sided observations. It may be impossible to tell how inaccurate the Jesuit interpretation of native Canadian cultures is so long as the consideration remains within a limited North American scope. By contrast, Japan's language, culture and tradition have survived, which thus allows more scope for modern researchers to identify the misinterpretations made by western missionaries about the Japanese.

A tangible identification of European missionary biases, at least better than one based merely on ambiguous speculations, is possible through examination of the mission in Japan. Japanese historical knowledge may help to verify the misinterpretations of the Jesuits. The Jesuit experience in this archipelago will help to answer the first and second questions above. The general identification of western biases can then be transferred to the North American context in order to find clues that may answer the third question.

The sections below will make a threefold argument. First, Jesuit interpretations of Japanese culture will be contrasted with Japanese 
reality that can be recognised from a thorough non-European standpoint and thus is independent of the influence of Euro-Christian missionaries. This contrast will reveal the probable epistemological mistakes and cultural biases of the priests. Second, this identification of misunderstandings and biases will be applied to the written cultural observations of the evangelistic successors, the Jesuits of New France. Third, probable biases will be eliminated from the reading of the French missionary accounts to arrive at a more plausible image of several aspects of Amerindian culture.

\section{A. The Jesuit Interpretation of Japanese Culture}

To prepare for effective preaching, the Jesuits in Japan attempted a thorough observation of the nation, as is documented in their correspondence. The Jesuit biases are evident in two categories of observations. One group consists of first-hand observations based mainly on their five senses, while the other group consists of second-hand observations or knowledge acquired from local informants.

\section{First-hand Observations}

Direct observations can be found in the descriptions of the Japanese people. In the first place, this type of description was influenced by what may be called a wilful manipulation of direct observations. An example can be found in two letters of Father Francisco de Xavier. One letter admires the Japanese people while the other criticises them. In his letter of 5 November 1549, only three months after his arrival at Kagoshima, Father Xavier commented:

First of all, the people with whom we have thus far conversed are the best that have as yet been discovered; and it seems to me that no other pagan race will be found that will surpass the Japanese. They have, as a race, very fine manners; and they are on the whole good and not malicious. They have a marvellous sense of honour and esteem it more than anything else. As a race they are generally poor, but the poverty that is found among the nobles and those who are not is not deemed to be a matter of reproach. ${ }^{1}$

1 To his companions living in Goa, from Kagoshima, 5 November 1549, in M. Joseph Costelloe, SJ (ed.), The Letters and Instructions of Francis Xavier (St. Louis, Missouri: The Institute of Jesuit Sources, 1992), epistola [ep., hereafter] 90, p. 297, in 
In another letter addressed to Father Simão Rodrigues in Portugal, dating 8 April 1552, after he left Japan for India, he related:

...they [Carlos V, Spanish Emperor, and Felipe and Isabella, the king and queen of Castile] should not send any more fleets from New Spain to discover Silver Islands [Japan]; for... they would be lost; and even if they were not lost at sea and reached the islands of Japan, the people there are so belligerent and avaricious that they would seize all the ships coming from New Spain.... Further, as I have already indicated, the Japanese are so greedy that they would slay all of them in order to obtain their weapons and the wares.... ${ }^{2}$

These remarks by Father Xavier are not contradictory, even though they appear so. He did not intend to deceive his correspondents. He simply emphasised two different aspects of the nation, with two different purposes in mind. He was a pioneer missionary to Japan. When he sent the letter in 1549 , he had to justify his choice of this nation as the object for Christianisation, and pointed to the positive aspects of the people. In Japan, he had limited access to overseas information, but once in Goa, he obtained more information about Spanish colonisation in the South China Sea. The Portuguese and Spanish in East Asia were about to enter into conflict in the 1550s. According to his second letter, he learnt of a Spanish plan to reach Japan from the Philippines, which had just been conquered by the Spanish fleet. Either he wanted to maintain the Jesuit monopoly of the mission over Japan by dissuading Spanish Friars; or he was worried about a war between Spain and Portugal over Japan, whose silver mines were invaluable. Thus, he urged Father Rodrigues to speak on his behalf to the Spanish emperor directly, or indirectly through the Portuguese King or Queen. Depending on Father Xavier's objectives, the Japanese were either well suited to become Christians or a belligerent enemy of Iberian colonisation. This comparison of two apparently contradictory passages by Father Xavier shows that missionary descriptions were determined pragmatically by current intentions.

In the second place, the Jesuit observations of the Japanese were influenced by interpretive biases. Because of their European and Christian origin, Jesuit missionaries were prone to interpret their experience by

Kôno Yoshinori, SJ (ed.), Sei Furanshisuko Zabieru zenshokan (Tokyo: Heibon-sha, 1985), ep. 90, p. 471.

2 To Father Simão Rodrigues, in Portugal, from Goa, 8 April 1552, in Costelloe, op. cit., ep. 108, p. 378, Kôno, op. cit., ep. 108, pp. 617-18. 
what they believed to be common sense. The Jesuit observations cover a wide spectrum of Japanese culture, which include two basic groups of subjects. The first group comprises climate, weather, diet, agricultural product, protocol, peace and order, and architecture. Except in rare cases, the missionaries normally made objective interpretations on these topics. The second group involves physical appearance and behavioural patterns. It is mainly in the observations of these second themes that the Jesuits were unable to escape their interpretive biases.

To the Jesuits, physical appearance was the first detectable difference. Their criterion for judging was apparently skin colour-the lighter the better. In 1565, Father Luis Frois wrote that the people of Japan had fair skin and a well-proportioned physique. ${ }^{3}$ The same year, Father Gaspar Vilela shared the same observation by noting that the complexion of every Japanese was fairer than that of the Portuguese. ${ }^{4}$ The Jesuit fathers used the references to fair complexions for their appraisal of the people whom they intended to Christianise.

A contrast is found in the observations of the Visiting Father, or padre visitador, Alessandro Valignano's confidential letter to the Jesuit general superior. Father Valignano criticised Father Francisco Cabral, ex-vice-superior of Japan, and wrote that Father Cabral erred in dealing with Japanese brothers by treating them like servants. According to Josef Franz Schütte, SJ, who thoroughly studied Father Valignano's confidential correspondence preserved in Rome, the visiting father wrote in 1595 that Father Cabral had spoken to them harshly and angrily and had called them 'Negroes [Neger]' and 'low-class people [niedriges Volk]'..$^{5}$ In this case, Father Cabral used the colour of skin in order to demean his Japanese colleagues. The colour of a non-European

${ }^{3}$ Luis Frois, to his companions in India and China, from Kyôto, 20 February 1565, in Matsuda Kiichi et al. (eds.), 3rd ser. of Jûroku-shichi seiki Iezusukai Nippon hôkokushû (Kyôto: Dôhô-sha, 1988-1996), vol. 2, 304-05 [hereafter, Matsuda, Hôkokushû 3, 2: 304-05].

${ }^{4}$ Gaspar Vilela, to the fathers in Avis, Portugal, from Sakai, 15 September 1565, in Matsuda, Hôkokush û 3, 3: 20-21. Cf. Okada Akio (ed.), Yôroppa bunka to Nippon bunka (Tokyo: Iwanami shoten, 1991), 18.

${ }^{5}$ These phrases are based on Josef Franz Schütte's citation of a letter of Alessandro Valignano, to the general superior in Rome, from Goa, 23 November 1595. Schütte writes, 'er [Cabral] sprach sehr hart zu ihnen und mit viel Zorn, nannte sie Neger, niedriges Volk, und gab ihnen andere beleidigende und unhöfliche Ausdrücke.' Father Valignano's original Latin words are not quoted. See Josef Franz Schütte, SJ, Valignanos Missiongrundsätze für Japan (2 parts, Roma: Edizioni de Storia E Letteratura, 1951-58), part 1, 325-31, esp. 325; and Josef Franz Schütte, SJ, Valignano's Mission Principles for Japan (2 parts, St. Louis: The Institute of Jesuit Sources, 1980), part 1, 255-60, esp. 255. 
complexion was described either 'as fair as Europeans' or 'as dark as Africans', depending on intent.

More detailed descriptions are found in Father Frois's cultural comparison between Europe and Japan, whose long title ends with Europa e esta provincia de Japão [Cultural Comparison, henceforth]. ${ }^{6}$ The content of his comparison, often irrelevant to evangelistic promotion, may have been useful only to his brethren in Japan and may have been insufficient for enlightening European readers. The manuscript thus remained unpublished throughout the missionary period. Although this pamphlet represents overall an objective comparison, it contains some remarks that suggest his cultural prejudice. For instance, Father Frois seems to have found it difficult to understand the metaphorical proof of bravery in war as demonstrated by a scar on the face. He noted that 'while we Europeans consider ourselves to be ugly with a scar on the face, Japanese men are proud of their ugly scarred face that they do not treat well'. Second, he did not agree with the fashion among the wealthy men, who wore patchwork coats decorated with brocades of gold and other attractive colours. He remarked that while patchworks were extremely demeaning to Europeans, the Japanese nobility treasured a whole patchworked qimão [kimono] or dóbuqu [dôbuku, a kind of overcoat for the upper classes]. Third, he commented, with reference to a fur dôbuku, that it would be insane for us to wear uncut and unsewn clothes'. Fourth, as far as he was concerned, walking without socks was unacceptable even in the humid climate of Japan. He wrote that if a woman strolled around without socks, Europeans ['we', including Frois] would think her crazy or shameless. Fifth, he was also unable to appreciate the smell of natural hairdressing oils for women. He noted that, while European women rendered their hair fragrant with perfumes, Japanese women always smelt foul because of the oil on their hair.?

Father Frois also condemned Buddhism. The Jesuits were displeased with anything that they believed was unacceptable to Christianity. They considered pagan idols hideous and inferior to Christian images. Father Frois related that while Christian icons were beautiful and induce devotion, Japanese Buddhist icons were unsightly and instilled

${ }^{6}$ Tratado em que se contem muito susintae abreviadamente algumas contradições e diferenças de custumes antre a gente de Europa e esta provincia de Japão (1585). The text this study uses is Okada Akio (ed.), Yôroppa bunka to Nippon bunka (1965, Tokyo: Iwanami shoten, 1991).

${ }^{7}$ Okada, op. cit., chap. 1, articles [art., hereafter] 11, $41 \&$ 57; chap. 2, art. 4 \& 20. 
feelings of horror because they resembled Satan being consumed by fire. ${ }^{8}$ According to Father Vilela, in another document, there were ugly drawings in those shrines that were dedicated to the sun, the moon, or a demon itself. ${ }^{9}$

\section{Second-hand Observations}

The Jesuit biases were not limited to first hand observations. They also acquired information indirectly. This indirect information gleaned from their native informants was filtered through a Jesuit bias. The missionaries' foci in their accounts were what they considered to be pagan religions and social structures. These were the two aspects of Japanese culture that they needed to study for combating paganism and for gaining local support in a foreign country.

\section{a. Interpreting Non-Christian Worship}

To begin with, the Jesuits relied on a Christian framework in order to interpret Buddhism, Shintô, and other forms of worship. In 1552, for example, to identify the Japanese deity, or to constitute a parallel to the Christian God, Father Xavier looked for a Supreme Being that was the object of Japanese worship, since he assumed that there must be a single God-like Being that was worshipped in Japan. He identified Shaka and Amida as the two main Buddhist idols for worship and pointed to the sun and the moon as other objects of veneration. Another appellation he applied to each of them was 'demon', which he and his brethren should defeat with God's help. ${ }^{10}$ Along the same lines, in 1557, Father Vilela also tried to discover what object or 'god' the Japanese would worship. He enumerated Amida, Shaka, the sun, the moon and demon-representing beasts. ${ }^{11}$ Father Cosme de Torres added kannon, a bodhisattva, to this list in $1561 .^{12}$ It was in 1585 when Father Frois categorised these objects of worship into two groups of

${ }^{8}$ Okada, op. cit., chap. 5, art. 8.

9 Gaspar Vilela, to his companions in India and Portugal, from [Hirado,] Japan, 29 Octber 1557, in Matsuda, Hôkokushû 3, 1: 263.

${ }^{10}$ Francisco de Xavier, to his companions in Europe, from Cochin, 29 January 1552; Xavier, to his companions in Goa, from Kagoshima, 5 November 1549, in Costelloe, ep. 90 \& 96, 298, 327 \& 336-37, in Kôno, ep. 90 \& 96, 472-73, 522 \& 536.

${ }_{11}$ Gaspar Vilela, to his companions in India and Portugal, from [Hirado,] Japan, 29 Octber 1557, in Matsuda, Hôkokush û 3, 1: 262-63.

${ }_{12}$ Cosme de Torres, to Antonio de Quadros in India, from Bungo, 8 October 1561, in Matsuda, Hôkokushû 3, 1: 340-41. 
deities: 'kami', or Japanese deities, and 'hotoke', or Buddhas. In Father Frois's statement, Buddhas included Shaka, Amida and other Buddhist idols while the kami included, inter alia, the sun deity, the harvest deity and war deity. He noted that people sought the forgiveness and assistance that they would need in the afterlife from Buddha, and that they wished to obtain from the kami such material benefits as health, longevity, wealth, childbirths and victory in war. ${ }^{13}$

There is one misunderstanding in this search for worshipped objects. The Jesuits seem to have asserted that Buddhist icons represented the core of Buddhism just as God was at the core of Christianity. The problem was that they relied on a Christian paradigm, and thus they failed to understand that there was a mystical law at the core of Buddhism and that Shaka or Amida was the individual who was believed to have fulfilled this law and enlightened himself as a Buddha.

Even though they noted the absence of Christian thought among the Japanese, the Jesuits continued to interpret Japanese spirituality through the lens of Christianity. Probably assuming that the Apostle Thomas had preached Christianity in eastern parts of the Asian continent, a widely held myth since the first century, Father Frois affirmed that common Christian concepts, like the Creator, the Saviour, the immortality of the soul, the glory of God and eternal happiness, had disappeared, since Thomas's visit, from the memory or knowledge of the Japanese. ${ }^{14}$ Ironically this missionary interpretation depended heavily on these Christian frameworks, which, Father Frois admitted, were entirely absent among this nation.

Heaven was a key, and the Jesuits believed that it was a part of Japanese spirituality. Accordingly, at Sakai in the early 1560s, Father Vilela attempted to learn how people understood heaven. His account described what he considered to be a false heaven. His understanding was that the Japanese people believed in numerous heavens where saints welcomed their adherents. According to him, Kannon followers wished to reach a heaven located under the sea, and Amida sectarians would go to another heaven. ${ }^{15}$ His idea of this Buddhist heaven is problematic because a Christian concept of heaven does not

\footnotetext{
${ }^{13}$ Luis Frois, to the general superior, from Nagasaki, 27 August 1585, in Matuda, Hôkokushû 3, 7: 61-63.

${ }^{14}$ Luis Frois, to his companions in China and India, from Kyoto, 20 February 1565, in Matsuda, Hôkokushû 3, 2: 306-07.

${ }^{15}$ Gaspar Vilela, to his companions, from Sakai, 1562, in Matsuda, Hôkokushî 3, 2: $82-83$.
} 
lead to an understanding of the Buddhist afterworld. In Buddhism, people could go to a sky world above the human realm after death, but that is only the fifth world from the top in the Buddhist ten-level hierarchy of enlightenment and obviously not a desired physical destination. What Buddhists hope to reach in their afterlife is the world of Buddha, which they believe to exist at the summit, far above the sky. What Father Vilela considered to be the Japanese version of heaven can be either a one-level-higher sky or the highest spiritual state of Buddhism, or even some ambiguous confusion of both.

The Creation was another concept used by the Jesuits in their attempt to understand the Japanese idea of the world's origins. In 1563, Father Vilela heard about a Japanese concept of Creation from the people in Kyoto. He explained three ideas about this concept without clarifying their spiritual origins. The first one was a secular story. The world was initially shaped like an egg. When a storm broke it, the albumen became the sky and the yolk and shell became the sea and land, from which creatures were born. The second one was almost a Buddhist view although Father Vilela did not recognise it as such. The beginning of the world was nothingness with no creation or genesis myth, as in Christianity. Everything visible came into existence only through a natural power. Father Vilela did not recognise the Japanese idea of Creation directly within the range of what the Jesuits regarded as Japanese spirituality, and thus resorted to an ancient myth of this country. The archipelago of Japan was created in a huge lake by a kami called Izanami, and all the inhabitants were descendants of Izanami and his wife Izanagi. ${ }^{16}$

Also, the Christian concept of Sin, Judgement and Atonement informed the missionary understanding of Buddha's rôle in the afterlife. In 1571, Father Frois commented on what he took to be a Buddhist form of remission of sins. He failed to understand that there was no Japanese custom of begging Buddha for the forgiveness of sin at the time of death. In the text, Father Frois made his Japanese Buddhist informant say that whichever sin one commits, merciful Shaka would forgive every sin with the help of his virtuous deeds. Father

\footnotetext{
${ }^{16}$ Gaspar Vilela, to his companions in India, from Sakai, 27 April 1563, in Mat-

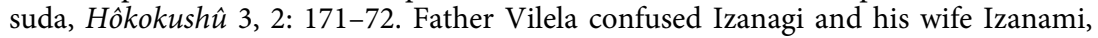
and quoted them in the opposite way. Although Vilela seemingly did not notice the importance of the last story, it is indirectly relevant with Shintô. In the myth, Izanagi was the ancestor of the Japanese sun deity.
} 
Frois seemingly borrowed a Christian framework and simply replaced 'God' with 'Shaka', and 'heavenly love' with 'virtuous deeds'. ${ }^{17}$

One of the most frequent and extensively-used expressions of the Jesuit reporters was a demon or a devil. The notion of the devil is close to the Buddhist idea of ma, or māra in Sanskrit, which means the evil deity hindering virtuous deeds. In a pre-scientific society such as sixteenth-century Japan, the causes of bodily illness were thought of as evil spirits, which Shintô priests or other shamans would try to exorcise. In a similar way, the Jesuits ascribed serious sickness to demons throughout the second half of the sixteenth century. For example, when Brother Duarte da Silva was repeatedly faced with paroxysmstricken people in Kutami, in Bungo of Kyushu in 1555, he concluded that demons possessed them. Brother Miguel Vaz reported also on Kutami that a demon had possessed a diseased Christian woman who was inflicted with severe symptoms and almost died before she was helped by a Jesuit prayer. In the annual reports for 1583 and 1591-92, Father Frois referred to several ill residents in Bungo, who he believed were possessed by demons and had to be helped by the Christian faith. In this second report, Father Frois noted that demons ailed the bodies of people causing not only illness but also death. ${ }^{18}$ The Jesuits presented no other possibility in diagnosing paroxysms and diseases.

The Jesuits, however, extended the term of devils or demons to a wider spectrum of life and used the term casually. A dualistic attitude to God and His enemy seems to have persuaded them to deem any spirit that they found against God to be demons. To be more precise, 'the meditation of the two standards' in The Spiritual Exercises written by Father Ignatius de Loyola is likely to have encouraged this concept of duality. According to Father Loyola, Christian life is a struggle between the poles of Jesus Christ and of Lucifer. This first general superior was a former soldier who organised the Society of Jesus along

${ }^{17}$ Luis Frois, from Kyoto, 10 March 1571, the recipient is missing, in Matsuda, Hôkokushû 3, 4: 57-58.

${ }_{18}$ Duarte da Silva, to his companions in India, from Japan [Bungo probably], 20 September 1555, in Matsuda, Hôkokushû 3, 1: 210-12; and Miguel Vaz, to his companions in Japan, from Bungo, 16 September 1566, in Matsuda, Hôkokush $\hat{u}$ 3, 3: 166; Luis Frois's report on 1583, to the general superior, 2 January 1584, in Matsuda, Hôkokushû 3, 6: 201-02; Luis Frois's report on 1591-1592, to the general superior, 1 October 1592, in Matsuda, Hôkokushû 1, 1: 292-94. 
military lines by giving superiors military titles. The use of the military metaphors would be perfectly natural for a Jesuit. ${ }^{19}$

As the pioneer missionary in Japan, Father Xavier, a contemporary companion of Ignatius Loyola, was the first to refer to the 'demons' in Japan. In 1551, when the mission of Father Torres and Brother Juan Fernández, working in Yamaguchi, was hindered by civil war, Father Xavier ascribed the cause of the warfare to the secret operation of the devil. He also asserted that Shaka and Amida, whom people worshipped, were not men but pure inventions of demons. ${ }^{20}$

Later Jesuits in Japan shared this basic idea of demons. The Jesuits extended the term of demons to almost any non-Christian spirit-like beings opposite to God. The three key phrases they associated with demons were first, worshipped idols; second, non-Christian-or pagan in a Jesuit sense-organisations; and third, spiritual practitioners. First, any non-Christian idols for worship were labelled demons in missionary accounts. For example, not only did Father Frois refer to Amida and Shaka as demons but he extended such appellations to include Kôbôdaishi, the founder of the Tendai Buddhist sect. After enumerating different icons that represented kami, Buddhist statues and popular deities such as beasts and natural products, Father Vilela maintained that the devils were responsible for misleading people to pray to all these allegedly demonised idols. In his explanation, there was no fundamental distinction among various sects of Buddhism and Shintô, and other popular forms of worship because all their objects of worship were commonly manipulated by the devil. ${ }^{21}$

Second, the Jesuits regarded any church-like organisation as a place for demonic activity. Father Frois contended that the Kasuga Shintô

19 Pierre Wolfe (ed.), The Spiritual Excercises of Saint Ignatius (Liguori, Missouri: Triumph, 1997), the fourth day of the second week, notes 136-48, pp. 38-40 \& 145-46.

${ }^{20}$ Francisco de Xavier, to his companions in Europe, from Cochin, 29 January 1552, in Costelloe, op. cit., ep. 96, 337-39, \& in Kôno, ep. 96, 536-39.

${ }^{21}$ Luis Frois, to his companions in China and India, from Kyoto, 20 February 1565, in Matsuda, Hôkokushû 3, 2: 306-10; Gaspar Vilela, to his companions at Avis in Portugal, from Goa, 6 October 1571, in Matsuda, Hôkokushû 3, 4: 148. Father Vilela enumerated ten objects of veneration he described as 'kami', including Benzai, Bishamon, Daikoku, Monju, Fudô, Kannon, Taga Daimyôjin, Yakushi, Marishiten and Hachiman; two Buddhas, Shaka and Amida; as well as seven other popular idols: foxes, snakes, bulls, deers, turtles, trees and stones. This represents an interesting mix of Shintô and Buddhist figures. It must be noted, however, that the syncretic image of Shintô and Buddhism was originally a Japanese tradition. With the spread of Buddhism in Japan, there developed a synchretic idea called 'Honji Suijaku', which showed that the Japanese kami was a form of the appearance, or Suijaku, of Buddha, or Honji. 
shrine in Nara deified a demon, but he did not apparently know that its enshrined deity was the progenitor of the historic Fujiwara clan, which had dominated imperial politics as regents from the ninth to the eleventh centuries. This means that any convert who followed Father Frois's preaching about the Kasuga shrine had to agree that a devil was the ancestor of the noble Fujiwara family. Also, Father Vilela contended that Buddhist temples belonged to demons and that Buddhists adored them. He wrote, in 1571, that all the two hundred Buddhist temples on Mount Atago, ten kilometres west of Kyoto, were, together with the mountain itself, devoted to demons. ${ }^{22}$

Third, the missionaries described as an agent of the devil any nonChristian who claimed that he or she possessed the power to deal with souls or spirits. Besides temple Buddhists, the Jesuits found another type of devil worshipper. In the sixteenth century, the only possible method for ordinary Japanese to cure disease was to exterminate the evil spirit inside the body of a patient with the help of shamans. The Jesuits explained that the shamans were servants of evil spirits, or the devil itself. Yamabushi, or mountain ascetics, were the devil's servants, as far as Fathers Frois and Cabral were concerned. According to them, Yamabushi adored the devil and devoted themselves to demonism. The missionaries stated that these mountain ascetics made a contract with Satan to perform witchcraft and exorcise demons from a human body. ${ }^{23}$ Thus, by blurring fundamental differences among the forms of worship, the Jesuits placed all kinds of Japanese beliefs under the single appellation of demonism or diabolism.

\section{b. The Social Structure}

The social structure of the Japanese was of further cultural interest to the Jesuits. Their European or Christian perspective helped the missionaries to understand Japanese feudal society. Their key words were power and authority, which came empirically from feudalism and

${ }^{22}$ Luis Frois, to his companions in China and India, from Kyoto, 20 February 1565, in Matsuda, Hôkokush û 3, 2: 306-10; Gaspar Vilela, to his companions at Avis in Portugal, from Goa, 6 October 1571, in Matsuda, Hôkokushû 3, 4: 134-35.

${ }^{23}$ Luis Frois, to his companions in China and India, from Kyoto, 20 February 1565, in Matsuda, Hôkokushû 3, 2: 306-10; Francisco Cabral, to his companions in Portugal, from Kuchinotsu, 9 September 1576, in Matsuda, Hôkokush û 3, 4: 285-86; Luis Frois, from Kuchinotsu, 13 February 1583 (the recipient is missing), in Matsuda, Hôkokushû 3, 6: 161-63. 
theocracy in Europe. Despite the differences between the European and Japanese feudal societies, the Jesuit interpretation of Japanese society, with a focus upon these two words, worked well in negotiations with the political authorities. Their accounts are partly on the subject of political negotiations with local and central rulers. For example, upon arriving in Japan, Father Xavier intended to meet the Japanese Emperor in Kyoto, a meeting that, as it turned out, never took place. ${ }^{24}$ The local Ômura, Arima and Ôtomo clans in Kyushu were always referred to as pro-Christian patrons in other reports. The correspondence from the Kansai regions in the third quarter of the sixteenth century often describes the missionary efforts at gaining the patronage of powerful warrior lords like Oda Nobunaga and his successor Toyotomi Hideyoshi. ${ }^{25}$

The Jesuits tried to make an analogy with power structures in Europe and studied the Japanese structure of power and authority to figure out the best evangelistic approach. In 1561, Father Torres pointed to three kinds of rulers. The first kind was the top priest of the Buddhist hierarchy, whom he considered to be a spiritual head. The second was the Emperor, whom he regarded as an honorary secular authority. Torres enumerated the nobility in Kyoto as the third kind of ruler. In his interpretation, this nobility had the political power and was in charge of the judiciary and administration. ${ }^{26}$

Father Frois amended this interpretation by referring to two kings. One was a king of power and political authority, or kôbôsama. He was probably referring to the shogunate, which enjoyed a degree of political authority but had lost administrative power in the civil war of the fifteenth and sixteenth centuries. The other was a king with spiritual authority, the Emperor. While Father Torres initially considered the Emperor to be a secular authority, later Father Frois corrected his idea and described the Emperor as a king of spiritual authority. ${ }^{27}$

In 1583, Father Valignano summarised Jesuit knowledge of the Japanese hierarchy in his confidential report to General Superior

${ }^{24}$ Francisco de Xavier, to his companions living in Goa, from Kagoshima, 5 November 1549; Francisco de Xavier, to his companions in Europe, from Cochin, 29 January 1552, in Costelloe, op. cit., ep. 90 \& 96, $310 \& 332$.

${ }^{25}$ This approach of winning over social leaders first was generally a standard Jesuit approach, not peculiar to the missionaries in Japan.

${ }^{26}$ Cosme de Torres, to Father Antonio de Quadros, superior of India, from Bungo, 8 october 1561, in Matsuda, Hôkokushû 3, 1: 338-40.

${ }^{27}$ Luis Frois, to his companions in China and India, from Kyoto, 20 February 1565, in Matsuda, Hôkokush û 3, 2: 306. 
Claudio Aquaviva in Rome. He pointed to the Japanese type of seigneurial system based on the redistribution of estates, in which a daimyô had absolute power over the lives and property of his retainers. He also divided Japanese feudal society into five social strata, which included first, daimyô as the top class; second, bonzes, or Buddhist priests; third, warriors; fourth, merchants and artisans; and last, at the bottom, peasants and servants. ${ }^{28}$

Father Frois's letter of 1569 represents the most perceptive account of this social hierarchy. He proposed that the missionaries should first gain the patronage of national or domain rulers and then use their favour and appreciation for Christian priests to achieve success among the nobility and populace. ${ }^{29}$ The limitation of these missionary analyses, however, was due to the fact that the priests were unable to understand the source of Japanese power and authority, which was derived from the creators of the Japanese islands in ancient mythology.

\section{Jesuit Biases}

Jesuit interpretations of Japanese culture were influenced by a combination of wilful descriptive manipulations and Euro-Christian biases. The intention of a correspondent sometimes determined which piece of information he would emphasise in his letter. It also determined how he would present his observations, either negatively or positively. Moreover, the cultural observations about non-Christian objects were influenced by interpretive biases. The European and Christian origins made the missionaries interpret the physical experience within the context of their own common sense. In viewing the opponents' or potential converts' physical appearances and characteristics, the Jesuits were unable to escape from their own European cultural values. They saw, for example, any non-Christian spiritual idols to be an unacceptable pagan symbol.

Jesuit biases also influenced the second-hand information gleaned from their native informants, and the biases were most conspicuous in the comprehension of Japanese beliefs and social structures. The Jesuits relied on a Christian framework of religion in order to interpret

${ }^{28}$ Alejandro Valignano, S. I., Sumario de las cosas de Japón (1583). The text used in this study is Matsuda Kiichi et al. (eds.), Nippon junsatuki (Tokyo: Heibon-sha, 1973), 6-8.

29 Luis Frois, to Father Belchior de Figuereido, from Kyoto, 12 July 1569, in Matsuda, Hôkokushû 3, 3: 341-42. 
Buddhism, Shintô, and other beliefs. Although they were aware that Japanese spirituality was different from Christianity, they still relied on basic Christian concepts to understand different Japanese customs within an assumed unity of the Japanese 'religion'. Consequently what they described conveniently as the Japanese 'religion' was a demonic synthesis of all non-Christian spiritualities that accurately represented neither Buddhism nor Shintô nor any other belief. In their understanding of the social structure, the Jesuits focussed on how to take advantage of it for a successful mission, but their study of the social structure did not help the missionaries to understand the Japanese spirituality that lay behind it.

There is, nevertheless, one fact that has to be borne in mind when discussing the biases of missionary accounts-that is the identity of the anticipated readers of each report. All the readers would be European brethren and supporters, who had no knowledge of Japan. The Jesuit correspondents were responsible for describing their experiences and observations as comprehensibly as possible. The readers would naturally understand the reports in a European language and with familiar references to European culture. That is how the missionaries had to communicate with the European readers no matter how accurately and truthfully the priests analysed the non-Christian nation. This necessary, rhetorical compromise is likely to have further exacerbated the interpretive biases, which may have been smaller in the minds of the Jesuits working in the archipelago. Therefore, the actual Jesuit biases need to be discounted to some extent.

\section{Propositions for New France}

The Iberian mission to Japan presents two proposed ideas for considering the French case in North America. The first idea is that the situations of the missionaries at each developmental stage of the mission generally determined the interpretations or the descriptions of non-Christian culture. However personal the written observations may appear to be, the thematic and interpretive descriptions were influenced more by the interests of the Jesuit religious order than by personal initiatives.

The second idea is that the biases that affected the cross-cultural understanding of Japan were not peculiar to the Iberian Jesuits. For discussing the missionary interpretations of non-Christian cultures in this respect, it is not important to examine how often or how seldom 
the French missionaries read the Japan reports; in short, the issue is not to determine how carefully the Jesuits read the accounts of Japan in French or in other languages. The French missionaries did not recognise that they might be repeating the same erroneous analysis that their Iberian predecessors had made in their established style of reports, because they were unable to learn from the Iberian mistakes. Admittedly there may have been differences in time and in origins between the sixteenth-century Iberian Jesuits and the seventeenth-century French Jesuits. ${ }^{30}$ Yet this kind of difference was minimal compared with the vast cultural differences between European perspectives and Japanese or Amerindian ones.

In the established rhetoric of the Jesuit reports, the seventeenthcentury French missionaries made an epistemological misjudgement similar to that of the sixteenth-century Iberian missionaries, since European readers in those centuries lacked an entirely non-Christian perspective that may have helped them to identify the Iberian misunderstandings. So long as the missionaries corresponded with the readers both in a European language and according to the Euro-Christian cultural value systems, their written accounts were ruled by European or Christian biases. These two identifications of biases will thus shed light on the French interpretations of Amerindian culture.

\section{B. The French Jesuit Interpretation of Native Culture}

From a contemporary seventeenth-century standpoint, Jesuit missionaries were masters of Euro-Christian knowledge and thus as capable of understanding non-Christian cultures as were any other European. The problem was they were able to do so only in their own systematic way. When approaching potential converts, the European missionaries

\footnotetext{
${ }^{30}$ For example, northern Europeans were affected by a witch-hunting mania in the 1600 s, and this would have affected the priests' view of alien spiritual beliefs. Also, there were all sorts of differences among people who did not follow the Roman Catholic Church. In addition to Christians who continued to believe in the old popular religions, there were Muslim descendents in Portugal and Spain while Protestants were making inroads in France in the sixteenth century. Until Spain conquered the Islamic kingdom of Granada in 1492 for the completion of the Reconquista, the Iberian Peninsula had been a place for Muslim residents ruled by the Nasrid dynasty. See, for example, William A. Christian, Local Religion in Sixteenth-Century Spain (Princeton, NJ: Princeton UP, 1981); and L. P. Harvey, Muslims in Spain, 1500 to 1614 (Chicago \& London: University of Chicago Press, 2005).
} 
encountered a wide gap between Christian and non-Christian cultures. Within the confines of early-modern western intellectual concepts, their analysis, albeit biased, was the best available at the time. Historians today, however, agree that the missionary interpretation of Amerindians is biased enough to be treated with caution.

The problem is that few authors have ever substantially identified the exact nature of the European and Christian biases that ruled seventeenthcentury missionaries. In Les Hurons-Wendats, for example, Georges E. Sioui implies that Jesuit comments on the indigenous people are not only culturally and religiously biased but also contemptuous, scoffing, or indifferent. ${ }^{31}$ Sioui, who claims to be of Wendat descent, frequently cites The Jesuit Relations for sustaining his ideas about an aboriginal heritage, but his lengthy monograph fails to illustrate how and where Jesuit accounts are biased. Also, Carole Blackburn, in Harvest of Souls, argues that the Relations are unreliable because the missionary descriptions of autochthonous customs are distorted. ${ }^{32}$ She is silent, however, when it comes to providing the reader with a concrete example of what she calls unreliability and distortions.

Some of the rare attempts to specify Jesuit biases can be found in the works of Elizabeth Tooker and Bruce G. Trigger. Tooker maintains that the missionaries had obvious biases in their observations of Amerindians, but she only gives one example, that is the missionary tendency to see demonism in native beliefs. Trigger focusses on thematic biases. The Jesuit attempts to analyse native culture, he contends, were pragmatic, and directed towards winning converts to Christianity. He affirms that the missionaries felt obliged to take note only of law, government and religion, which were vital in their dealings with indigenous people. Trigger also argues that the missionaries considered it unnecessary to write about other aspects, such as the kinship system, subsistence activities, trade and warfare. As for the biases of interpretations, his concerns are merely with the possible alterations

31 Georges E. Sioui, Les Hurons-Wendats: Une civilisation méconnue (Sainte-Foy, Québec: Les Presses de l'Université Laval, 1994), 264; Sioui, Huron-Wendat: The Heritage of the Circle (Vancouver \& Toronto: University of British Columbia Press; \& East Lansing: Michigan State University Press, 1999), 136.

32 Carole Blackburn, Harvest of Souls (Montreal \& Kingston: McGill-Queen's University Press, 2000), 4-5. 
during the editorial process, including the mutilations or poor copies of manuscripts and the distortions of original meanings. ${ }^{33}$

However biased, the French Jesuits attempted a thorough observation of their evangelistic subjects as did the Iberian missionaries. The Jesuits who experienced Amerindian culture landed first in Acadia in the 1610s, following which they established a base in Quebec in 1625. As in the Iberian case, their biases are evident in two basic categories, direct or first-hand observations and indirect or second-hand observations, although such a distinction is not entirely clear in some descriptions.

\section{First-hand Observations}

Fathers Pierre Biard and Énemond Massé were the Jesuit pioneers in North America, but their situation was different from Father Xavier's. These two Fathers were not pioneer missionaries in French North America, because Father Jessé Fléché, a priest of the diocese of Langre, had been there for a year when they arrived in Acadia in 1611. This complex factional situation seems to have coloured the Jesuit observation of the Mi'kmaq and the Maliseet, the native peoples in Acadia, just as the Iberian descriptions of the Japanese as potential Christian converts were adjusted, depending on the intention of the reporter.

The initial Jesuit task in their correspondence was to criticise the effort of Father Fléché. Father Biard commented harshly on the five native converts, seemingly healthy adults, who had been baptised by their missionary predecessor. According to the Jesuit father, these native converts at Port Saint John did not understand his question as to whether or not they were Christians. When they were asked alternatively whether they were baptised, the very best they could answer was that the patriarch had made them like Normans. Father Biard therefore asserted that there was no genuine conversion before the Jesuits arrived, and that the indigenous people were just as savage as they had been even after their alleged conversions by Father Fléché. ${ }^{34}$

${ }^{33}$ Elizabeth Tooker, An Ethnography of the Huron Indians, 1615-1649 (1964, Syracuse: Syracuse University Press, 1991), 07; and Bruce G. Trigger, The Huron (New York: Holt, 1969), 4-5; Bruce G. Trigger, The Children of Aataentsic (Kingston \& Montreal: McGill-Queen's University Press, 1976), 17.

${ }^{34}$ Pierre Biard, to Father Christophe Baltazar, provincial of France at Paris, from Port Royal, 10 June 1611, in Reuben Gold Thwaites et al. (eds.), The Jesuit Relations 
Unlike Father Xavier, who had to justify his own choice of the Japanese as missionary objects, the Jesuits in Acadia were under no obligation to describe the Amerindian population in a positive way. Father Biard's direct observations of the Amerindians as potential Christians were thus simply negative. In his account of 1611, the nation was 'savage', 'or sauvage', which meant uncivilised, and the 'savage' people were full of bad habits. The people were haunting the woods, ignorant, lawless and rude. Given to any kind of lewdness, they were also vengeful, lazy, gluttonous, profane and treacherous. They were vainglorious because they believed themselves to be more valiant, more ingenious and wealthier than the French. In the Relation, or the annual report, of the years 1613 and 1614, whose authorship may be either Father Biard or Father Massé, the tone becomes even more scornful. The people were united by no mutual interests, possessing no arts, and indolent in every occupation. On the whole, they were considered to be hardly above the beasts. ${ }^{35}$

The negative tone disappears in the Relation of 1616, three years after the armed English colonists drove the Jesuits out of Acadia. After a few years of missionary work, the Jesuit attitude changed to one of justification of their own activity. Perhaps in the hope of resuming the Acadian mission, Father Biard, then in Paris, finally attempted to justify the indigenous people as an appropriate missionary object. He now called the people 'our Savages', or 'nos Sauvages', a term that implied possessiveness of spirit, with little malice, as if to say that 'nos Sauvages', though happy, could be improved by Christian salvation. Also, their physical appearance was handsome and well shaped, which, like the light skin colour of the Japanese, made them appear to be good candidates for Christian conversion. ${ }^{36}$

A similar bias is detected in the observation of the historical Montagnais, now called 'Innu', belonging to the East Algonquian language group. ${ }^{37}$ In 1625, three Jesuit missionaries joined the Récollet Franciscans, who had been ministering in the settlement of Quebec

and Allied Documents (Cleveland, OH: Burrows Brothers, 1896-1901), vol. 1, 163-65 [henceforth, Relations 1: 163-65].

35 Ibid., in Relations 1: 173; and Relatio rerum gestarum in Novo-Francica missione, annis 1613 \& 1614, in Relations 2: 201.

${ }^{36}$ Pierre Biard's Relation of 1616, from Paris, in Relations 3: 73-75.

37 The East Algonquian people maintained their hunting and gathering culture. They included the Algonquin, Mi'kmaq, Maliseet, Innu and Ojibwa. For the relationship between the name of 'Montagnais' and that of 'Innu', see Paul Charest, 'Les 
since 1615. In 1632, after an interruption in their activity caused by the English rule of Quebec from 1629 to 1632, the Jesuits alone returned to New France, and among them was Father Paul le Jeune, the superior of New France. The initial Jesuit observations of the Innu were pessimistic. The expressions Fathers Charles Lalemant and Le Jeune applied to them included naked, beggars, licentious, lazy, rude, incapable of comprehension, fickle, capricious, polygamous, dirty in diet, vermin eaters, given to treachery in war, and cannibalistic or cruel to enemies. ${ }^{38}$

The disdain of the Jesuits decreased drastically in the later account of Father Le Jeune, who camped out with an Innu band during the winter of 1633-1634. After some missionary experience with Innu traders at Quebec, he decided to learn more about this people by actually living with them. Once he tried to include the Innu within the missionary flock of lost sheep, he also altered his assessment of them as missionary subjects. Father Le Jeune's Relation of 1634 uses such positive words as tall, erect, strong, well proportioned, and agile, with no effeminate characteristics. He also described the 'savages', probably with the Innu mainly in mind, as having a good quality of mind, for they have wellformed bodies and well-regulated organs. He expounded that their savage condition was only caused by the lack of education and instruction. He even admired their generosity by pointing to the absence of orphans among them. This was a dramatic change in attitude because he never wrote well of them throughout his Relation of 1632. The most positive thing he said about them there was that they had good minds, in spite of their barbarity and lack of formal education. ${ }^{39}$

As for the Hurons, who belonged to the Iroquoian language group, ${ }^{40}$ the situation was somewhat different. The semi-sedentary Hurons were important trade partners of the French ever since the establishment of Quebec. Their country near Lake Simcoe and Georgian Bay

Montagnais d'autrefois, les Innus d'aujourd'hui' in Cap-aux-Diamants 85 (printemps, 2006): 10-15.

${ }^{38}$ Charles Lalemant, to Jérôme Lalemant, from Quebec, 1st August 1626, in Relations 4: 197-99, 219; and Paul le Jeune's Relation of 1632, in Relations 5: 23-29, 53 \& 137. The cited descriptions may also refer to Huron traders who commuted annually to Quebec.

${ }_{39}$ Paul le Jeune's Relation of 1634, in Relations 6: 229-31 \& 239; and Le Jeune's Relation of 1632, in Relations 5: 31-35.

${ }^{40}$ The Iroquoians formed semi-sedentary farming societies. They included the Huron confederacy, later called Wendat, and the Iroquois nations. 
had been a missionary target since the arrival of the Franciscans in 1615. Because of the delayed participation of the Jesuits in the Quebec mission, Fathers Jean de Brébeuf and Anne de Nouë joined the Franciscans among the Hurons in 1626. The English occupation of Quebec from 1629 to 1632 also delayed a Jesuit report on the Huron nation. When Father Brébeuf finally had an opportunity to comment on the Hurons in 1635, the mission had been undertaken for two decades.

Given the existence of the Huron mission, Father Brébeuf s only option for his comments was justification of the Hurons as potential Christian converts. In the Relation of 1635 , he made positive comments about the Hurons to show the ease of converting them to Christianity. He pointed to their peaceful and flexible minds, which he found agreeable to Christian faith and law, besides their horticultural customs. As far as he was concerned, their vices and superstitions were due to minds that were untrained and untamed by Jesuit teaching. ${ }^{41}$

Father Brébeuf's observations contrast with the comment by Father Le Jeune, who was not in charge of the Huron mission and knew the Hurons merely as traders visiting Quebec. Father Le Jeune's negative comments on the Innu, who were 'sauvages', do not refer specifically to a single tribe, and refer to Huron traders also. In addition, he introduced them to the reader as skilled thieves who, he guessed, tried to show their intelligence through thefts. ${ }^{42}$

The above three cases of Acadia and the Saint Lawrence, along with the case of Father Xavier in Japan, indicate two intertwined aspects that influenced the French Jesuit observations of the indigenous peoples. They were, first, the value of the native people's importance as a missionary object and, second, or furthermore, the possibility for the successful evangelistic activity among them. When an observer, whether Iberian or French, commented on his missionary objects, he always tried to find some reason to expect them to accept Christianity. All priests, whether Iberian or French, always lived in hope of converting the non-Christian people. In the Iberian reports, the belligerent and avaricious Japanese in some accounts became the best-qualified candidates for Christianity in others. In the accounts of New France

${ }^{41}$ Jean de Brébeufs Relation of 1635, in Relations 8: 151-53; Lucien Campeau (ed.), Monumenta Novae Franciae (Roma: Monumenta Historica Soc. Iesu; Québec: \& Montréal: Bellarmin; or Québec: Les Presses de l'Université Laval, 1967-2003), vol. 3 (1987), 114-15 [henceforth, Campeau, Monumenta, 3: 114-15].

${ }^{42}$ Paul le Jeune's Relation of 1633, in Relations 5: 241-43. 
also, the Amerindians were no different from wild beasts when regarded as unsuited for missionary activity. Yet they were described as good-natured people with docile minds once counted as potential converts. When recording observations of the indigenous people, the priests wrote implicitly of their missionary plan in a new land rather than of their objective ideas of the Amerindians' genuine character.

\section{Second-hand Observations}

Just as with the direct observations, the indirect observations based on the information obtained from their Amerindian informants were also not free of biases. Despite the difference of locations, the main themes for the second-hand observations had not changed since the time of the Jesuit pioneer Francisco de Xavier. The French missionaries' written concerns were with the non-Christian religion and social structure. These were the two aspects of culture they investigated in order to replace paganism with Christianity and to win the support of native society as well.

\section{a. Non-Christian Worship}

The non-Christian religion, to begin with, was a primary theme in the Jesuit accounts of native culture, just as Japanese spirituality was in the Iberian accounts. This conceptual framework has not been revised substantially even in most of the twentieth-and twenty-first-century academic publications, except in The Huron by Trigger. ${ }^{43}$ Back in 1626, after failing to detect native religion, Father Charles Lalemant pointed to the lack of any institutional form of divine worship. Similarly Father Le Jeune asserted, in 1632, that the Amerindian people knew little religion if any, let alone the worship of any particular divinity. In 1635, Father Le Jeune more confidently noted that the people were devoid of

\footnotetext{
${ }^{43}$ Trigger, op. cit., 90-93. Although he deals with collective beliefs rather than religion in this work, native religion is the common framework of many other influential publications. See, for example, Alfred Goldsworthy Bailey, The Conflict of European and Eastern Algonkian Cultures, 1504-1700 (1937, second ed., Toronto \& Buffalo: University of Toronto Presss, 1969), 126-47; W. Vernon Kinietz, The Indians of the Western Great Lakes, 1615-1760 (1940, n.p.: Ann Arbor, 1965), 122-60; Tooker, op. cit., 72-121; Lucien Campeau, La mission des Jésuites chez les Hurons, 16341650 (Montréal: Bellarmin; \& Rome: Institute Historicum S. I., 1987), 97-112; and Shenwen Li, Stratégies missionnaires des jésuites français en Nouvelle-France et en Chine au XVII siècle (Saint-Nicolas, Québec: les Presses de l'Université Laval; \& Paris: Harmattan, 2001), 61-75.
} 
any religious notions. As late as 1710, Father Joseph Jouvency reviewed the Jesuit activity of the previous century and affirmed that there was 'no system' of religion in the native culture. ${ }^{44}$

This French denial of native religion is reminiscent of the Iberian priests' failed attempts to detect traces of the Apostle Thomas's Christianity in Japan. ${ }^{45}$ In each case, the missionaries refused to equate nonChristian customs with formal religion, since they were too rigid to go beyond the existing Christian framework of religion. The Jesuits initially believed that the First Nations had neither religion nor divine worship. Thus, one might assume that the missionaries interpreted native beliefs within a conceptual framework based on the Christian religion and divine worship. It is necessary to examine whether the French Jesuits made the same mistake as their Iberian predecessors, who reconstructed various Japanese beliefs into a single framework, which they thought logical, but which turned out to be rather chaotic.

Despite the initial denial of a native religion's existence, the French Jesuits employed basic Christian notions to understand the equivalents within Amerindian spirituality, just as did the Iberian missionaries. For example, the missionaries began their research with a presupposition that there should be some pagan idol for worship, since they assumed that Amerindians were pagans. Father Biard's report of 1616 shows his earnest attempt to find a native deity, which he managed to identify as the sun. According to him, the people in Acadia claimed that they believed in a god, but he was sceptical because they knew no prayers or any form of worship except for admiration of Niscaminou, the name of the sun.

The evangelists, however, did not remain as uncomprehending or as intolerant as Father Biard. The shift of interpretations about Amerindian ideas indicates that their observations improved towards the midseventeenth century. In 1626, Father Charles Lalemant identified the sun as an object for some native prayers although he maintained that

${ }^{44}$ Charles Lalemant to Jérôme Lalemant, from Quebec 1st August 1626, in Relations 4: 201-03; Paul le Jeune's Relation of 1632, in Relations 5: 33-35; Le Jeune's Relation of 1635, in Relations 8: 185; and Josepho Juvencio, SJ, De regione et moribus Canadensium seu barbarorum Novae Franciae (Rome: Ex Typographia Georgii Plachi, 1710), edited in Relations 1: 239-98, see esp. 287-89.

${ }_{45}$ The influence of the Apostle Thomas's Christianity has not been confirmed in the history of Japan. Most probably Christianity was not imported to Japan before the Jesuit mission. See for example, Takao Abé, 'The Seventeenth-Century Jesuit Missionary Reports on Hokkaido', Journal of Asian History 39 (2005): 111-28. 
the indigenous people knew no authentic prayers like the ones represented at the Christian church. Father Brébeuf explained, in 1636, that the Hurons addressed themselves to some demon that resided in the earth, rivers, lakes, and above all, the sky. They also worshipped rocks. On their way to Quebec, Father Brébeuf noticed that the Huron traders revered an enormous rock. According to legend, the rock had once been a man. Father Brébeuf also noted that they would seek recourse to the sky in order to obtain daily necessities. He noted the native respect for the great divine bodies in the sky. ${ }^{46}$

When interpreting worshipped objects, the Jesuits also searched for a native god, which they somehow assumed to be the native Creator. Father Le Jeune, in 1632, referred to the Creator and the restorer of all things, whose Algonquian names were Atahocan, or Atachocam, and Messsou. He maintained that this Creator implied some idea of a god. Later in 1634, he added Nipinouskhé and Pipounoukhe, who brought the seasons, as well as Khichikouai, who taught men where to hunt game. And yet he failed to find any hint of veneration in the way that the indigenous people treated these 'gods'. In the case of the Hurons, Father Brébeuf attempted to understand how the indigenous people saw their gods by citing the fables of their origin. To the reader in France, he introduced a Huron version of the Creation story, with a focus on Aataentsic, her unnamed husband and their two boys called Tawiscaron and Iouskeha, or Jouskeha. According to him, while travelling in Heaven to find some healing fruit for her ill husband, Aataentsic fell from Heaven onto a giant Turtle on the earth and brought forth two boys, and these three people created all the creatures on the land and in the water. This Aataentsic was the moon and Iouskeha was the sun. $^{47}$

Accordingly the Creation story became another notion by which the Jesuits attempted to understand native culture. Father Brébeuf's account of Aataentsic and other Creators, cited above, shows his attempt to learn about the Huron idea about Creation. He also tried to learn who created Heaven and earth, but was unable to elicit any

${ }^{46}$ Pierre Biard's Relation of 1616, in Relations 3: 133-35; Charles Lalemant, to Jérôme Lalemant, 1 August 1626, in Relations 4: 203; and Jean de Brébeuf s Relation of the Huons of 1636, in Relations 10: 159-61 \& 165.

${ }_{47}$ Paul le Jeune's Relation of 1632, in Relations 5: 151-57; Le Jeune' Relation of 1634, in Relations 6: 157-59 \& 173; and Brébeuf's Relation of the Hurons of 1636, in Relations 10: 127-139. 
concrete idea from his Huron informants. Fathers Brébeuf and Le Jeune both explained that the Algonquin and Huron peoples believed in the great turtle that held up the earth at the time of Creation. Both priests, however, clearly recognised that the native Creation myth was a fable with no religious overtones. ${ }^{48}$ The native Creator was not in the least an object for religious worship. Their reference to the native Creation myth was thus mainly to show their effort and solution for expounding the Christian idea of the Creation in a way comprehensible to non-Christian people. It may be an inappropriate historical interpretation to describe this world-construction fable as the main element for Jesuit comprehension of the Amerindian religion as do W. Vernon Kinietz and Lucien Campeau, who has apparently accepted the seventeenth-century missionaries' rhetorical paradigm of religion as the universal framework that is even now applied to Amerindian spirituality. ${ }^{49}$

To understand Amerindian spirituality, the Jesuits had recourse to the Amerindian ideas about the immortality of the soul, both in Acadia and in the Saint Lawrence. Their focus, however, seems to have been on whether irreligious Amerindians were capable of understanding the Christian notion of the soul, just as the Iberian Jesuits confirmed the Japanese recognition of the soul through the Buddhist belief in an afterlife. Father Biard's Relation of 1616 suggests that he tried to find out whether or not they understood the idea of a soul. His conclusion was that the native idea of the soul existed but that they were not clear about the soul's immortality and about the future reward and punishment to the soul. Father Charles Lalemant in Quebec seems to have made the same attempt in 1626, even though he wrote instead that the Amerindians believed in the immortality of souls. ${ }^{50}$

The native idea of the soul was beyond the understanding of French missionaries. According to Father Charles Lalemant in 1626 and Father Le Jeune in 1637, the Algonquin imagined that, in the other

48 Jean de Brébeuf Relation of the Hurons of 1635, in Relations 8: 147; Brébeuf's Relation of the Hurons of 1636, in Relations 10: 129; and Paul le Jeune's Relation of 1637, in Relations 12: 73-75.

${ }^{49}$ W. Vernon Kinietz, op. cit., 122-23; and Lucien Campeau, op. cit., 106-08. Others like Elizabeth Tooker and George E. Sioui are more cautious in dealing with the Huron idea of Creation and discuss it in the category of myths. See Tooker, op. cit., 145-48; and Sioui, op. cit., 16-19.

${ }^{50}$ Pierre Biard's Relation of 1616, in Relations 3: 133-35; and Charles Lalemant, to Jérôme Lalemant, 1 August 1626, in Relations 4: 201-03. 
world after death, the souls would eat and drink and speak with each other, as did the living. Later, in 1639, Father Le Jeune realised that the people distinguished more than one soul in one body. In the Huron country also, Father Brébeuf retrieved from his informants an indigenous interpretation about the fate, or the destination, of the soul after death. After learning that the destination was somewhere to the west of the earth, he was reportedly astounded to learn of their solid faith in this oral tradition about the soul because the Christian interpretation about it was the only truth, as far as he was concerned. It is possible that what the missionaries depicted as the Amerindian souls was something beyond the soul, or even something else like symbolic and eternal spirits that could shift from one body after death and eventually to another body at birth. ${ }^{51}$

The lack of references to the native idea of births prevented further consideration, however. All the missionaries persisted in the notion of the soul and commonly explained that the contradiction was caused by a superstition or an erroneous idea of the indigenous people. Concentrating too much on the indigenous people's familiarity with the soul, the Jesuits never thought of going outside the Christian paradigm.

Heaven was another convenient clue to identifying the destination of souls after death. In 1626, Father Charles Lalemant learnt that native souls, after death, would go to the other world. His Christian bias helped him to leap to a conclusion that this other world was the same as what Christians called Heaven. Later correspondents, however, did not repeat this interpretation. In 1636, Father Brébeuf noted that the Huron otherworld was somewhere far away on the earth, and thus he did not call it Heaven. Instead, he presented the notion of the sky, which was at least closer to the Christian Heaven. ${ }^{52}$ In truth, the Amerindians did not have a concept of Heaven as the settlement of the virtuous.

As was the case with Iberian missionaries, the conflict between God in Heaven and some rival spirits seems to have ruled the French interpretation of the Amerindian deity. The Jesuits found some supernatural

${ }^{51}$ Charles Lalemant, to Jérôme Lalemant, 1 August 1626, in Relations 4: 201-03; Paul le Jeune's Relation of 1637, in Relations 12: 27-29; Paul le Jeune's Relation of 1639, in Relations 16: 191-93; and Brébeuf's Relation of the Hurons of 1636, in Relations 10: 143-149.

${ }^{52}$ Charles Lalemant, to Jérôme Lalemant, 1 August 1626, in Relations 4: 201-03; and Brébeuf's Relation of the Hurons of 1636, in Relations 10: 143-149 \& 159-61. 
spirit in the native culture. The Algonquian name of the native spirit was 'manitou' while its Huron or Iroquoian name was 'oki' in the singular or 'ondaki' in the plural. Because it was different from a Christian spirit, the Jesuits did not hesitate to call it the devil or a demon. Father Le Jeune first learnt that the Innu people believed it to be an angel or some powerful being which was a source of evil and the cause of illness. He enumerated three kinds of manitou, or demons: first, the originator of disease; second, the cause of death; and third, manitou that presided over war and created the earth. To Father Le Jeune, a Christian, to think that a demon created the earth must have been too difficult and too confusing to understand. Suddenly at this point, his account abandons the devil when referring to this third manitou and instead calls it a god. He questioned his informant as to where this god was before Creation, but the informant was unable to answer any further. Father Le Jeune's category of manitou is limited to the first two kinds later in the same report, and the third kind of manitou as the Creator never reappears in his or other accounts. ${ }^{53}$

The missionaries in the Huron country tried to explain the oki in a way comprehensible to European Christians. Father Brébeuf inferred that his Hurons honoured a demonic divinity called 'oki' or 'ondaki', which they imagined to be in the sky and to control the seasons of the year. Father Paul Ragueneau explained that his Hurons accepted any unnatural or extraordinary happening as a spiritually powerful oki. He also learnt that the native people believed that an oki, or a powerful genie, would enter shamans' bodies or appear in their dreams, and would show them supernatural wonders. In addition, Father Brébeuf recognised that the oki was also used metaphorically, referring to those esteemed individuals who had performed miracles. ${ }^{54}$

The use of an oki as a simplistic synonym for a devil or a demon is found, for example, in the following three Jesuit reports. Father François-Joseph le Mercier called an oki a demon which, according to a Huron charlatan, lived in the house of ondaki under the ground before surfacing. Also, Fathers François du Péron and Jérôme Lalemant

${ }^{53}$ Paul le Jeune's Relation of 1633, in Relations 5: 157; Le Jeune's Relation of 1634, in Relations 6: 175; \& 7: 181-83; and Le Jeune's Relation of 1636, in Relations 9: 81-83, $125-27 \& 209-11$.

${ }^{54}$ Jean de Brébeuf's Relation of the Hurons of 1635, in Relations 8: 99-101; Brébeuf's Relation of the Hurons of 1636, in Relations 10: 49 \& 161; and Paul Raguenau's Relation of the Hurons of 1648, in Relations 33: 193 \& 211. 
simply called this native spirit 'the devil' or 'the demon' who spoke to Hurons in dreams, in the form of a crow, a serpent, other animals, a flame or a ghost. In these forms, recounted Father Lalemant, the demons reportedly revealed the secret of good fortune in the recovery of health or in achieving success in work. Considering all the statements by these six Jesuit correspondents, the native manitou or an oki was something more complex than the devil. In this Jesuit rhetoric, however, there was no other appellation but 'demon' or 'devil' for indicating any non-Christian spirit holding supernatural power, the power that in Christianity was exercised by God. ${ }^{55}$ This was also the case in the Iberian accounts.

In connection with the devil, the Jesuit missionaries paid attention to two aspects of Amerindian culture: native shamans and rituals, such as feasts or ceremonies. These are also reflected in Father Brébeuf's observation of the Huron people, that they had neither temples, nor priests, nor feasts, nor any ceremonies. His statement represents the Jesuit idea about these four necessary religious components. Although the missionaries found no temples among them, they detected native shamans, as the equivalents for priests, and indigenous rituals, as equivalents for feasts and ceremonies.

Just as the Iberian missionaries made frequent references to Buddhist bonzes and Shintô priests, the French missionaries paid critical attention to native shamans. The reporters used a variety of terms, which included sorcerers, soothsayers, jugglers, charlatans, magicians, medicine men, deceivers and ministers of Satan or of Hell. ${ }^{56}$ Their analysis of the rôle of shamans was directed towards interpreting what the people expected and anticipated from the Amerindian spirits that they called demons. According to Father Le Jeune, for example, the Innu believed that their sorcerers could kill people with charms by communicating with manitou. He also referred to an Innu 'juggler'

${ }_{55}$ François-Joseph le Mercier's Relation of the Hurons of 1637, in Relations 13: 105-07; and François du Péron, to Joseph-Imbert du Péron, from Ossossané, 27 April 1639, in Relations 15: 177; and Jérôme Lalemant's Relation of the Hurons of 1639, in Relations 17: 153-55.

${ }_{56}$ Pierre Biard, to the general superior, from Port Royal 31 January 1612, in Relations 2: 75; Paul le Jeune's Relation of 1635, in Relations 8: 123-25; Le Jeune's Relation of 1636, in Relations 8: 273; Jean de Brébeuf's Relation of the Hurons of 1636, in Relations 10: 197; Le Mercier's Relation of the Hurons of 1637, in Relations 13: 105-07; Jérôme Lalemant's Relation of the Hurons of 1639, in Relations 16: 195-97; Lalemant's Relation of 1640, in Relations 19: 83 \& 179; and Paul Ragueneau's Relation of the Hurons of 1648, in Relations 33: 203-07. 
who was believed by his country people to restore the health of the sick by dealing with manitou, only in exchange for treasures like porcelain, beads necklace and beaver pelts. As a faithful reader of accounts of the Japanese mission, Father Le Jeune compared this native shaman scornfully to Japanese bonzes, who claimed the power to lead their wealthy supporters to paradise, or, to be more precise, to the world of Buddha, provided they paid a fortune. Apparently the shaman never provided the same services to the poor. Father Brébeuf, too, noticed that the Huron sorcerers attempted to cure diseases only after having received generous presents and good pay. ${ }^{57}$

The Jesuit interpretations of Huron shamans were more detailed than the interpretations of Innu shamans because of their regular residence in the Huron country, even though missionaries' basic attitude was the same as Father Le Jeune's. Father Brébeuf learnt that there were four kinds of Huron shamans who would perform their duties allegedly with the assistance of native genies. The first kind of shaman was presumed to command the rain and winds. The second kind predicted future events. The third kind tried to find lost objects. And the fourth kind would restore health to the ill. As to the last type of shaman, Father Jérôme Lalemant later distinguished two further kinds: magicians, who determined the nature of diseases and those who give remedies. He also differentiated metaphorically between magicians and sorcerers. According to him, the Hurons distinguished successful shamans from unsuccessful ones by their ability to predict the identity, number and locations of their enemies in war. The former, or magicians, were honoured publicly as angels of light, and the latter, or sorcerers, were abominated as angels of darkness. ${ }^{58}$

Despite all these differences, the Jesuit accounts treat all the shamans commonly as demonic agents allegedly communicating with the devil, as does the Iberian correspondence against the Buddhist and Shintô practitioners in Japan. It is true that the priests' attitude represented their firm belief in monotheism, in which there is only one true God and other supernatural beings must be false or antagonistic. Yet

${ }^{57}$ Paul le Jeune's Relation of 1636, in Relations 8: 271-73; and Le Jeune's Relation of 1637, in Relations 12: 07; and Jean de Brébeuf's Relation of the Hurons of 1635, in Relations 8: 123.

${ }^{58}$ Jean de Brébeuf's Relation of the Hurons of 1636, in Relations 10: 193-95; Jérôme Lalemant's Relation of the Hurons of 1639, in Relations 17: 211-13; and Lalemant's Relation of the Hurons of 1640, in Relations 19: 183. A more detailed description of the Huron shamans is in Kinietz, op. cit., 131-35. 
more significantly the French missionaries repeated the mistakes of the Iberian missionaries, since the Iberian predecessors themselves failed to recognise their epistemological errors and did not admit them in their reports.

Some native rituals were aspects of demonism from a Jesuit perspective. In the Relation of 1636, Father Brébeuf referred to four kinds of Huron feasts: feasts of thanksgiving or gratitude; farewell feasts; feasts for singing and eating; and feasts for deliverance from an illness. Later in the same report, he added the feast of the dead, held every twelve years, in which people confirmed their friendship and harmony. Father Brébeuf gave no detailed explanation for thanksgiving. According to him and other missionaries, farewell feasts were held by a dying individual for his friends and prominent people. Singing feasts were held when a person had performed a notable act, when a person intended to take a new name, and when the people planned to go to war. Father Jérôme Lalemant's interpretation was more controlled by demonism. In his observation of the Neutrals, or the Atiwandaronk, in 1642, he related that most of the feasts were sacrifices to the devil. What the Jesuits most commonly associated with the devil were, however, the feasts or rituals for healing the sick..$^{59}$

To the French missionaries, the native healing ceremonies, which included no European-style medical treatments, represented demonic shamanism, as did the healing activity of Japanese yamabushi to Iberian missionaries. Father Brébeuf referred to a curing feast or chant when his Huron hosts sang to eliminate the demon that had caused a disease. He also recounted two healing games for curing the sick, directed either by a shaman or by a dream. He learnt that the native shamans would perform such rituals as feasts, dances and songs for determining which evil was the cause of disease. As far as Father Lalemant understood, the native dances, feasts and other curing ceremonies were taught by demons. In his written opinion, the dances and feasts for healing the ill and the success of the native social activity always accompanied a desire inspired by a demon. Thus, most feasts

59 Jean de Brébeufs Relation of the Hurons of 1636, in Relations 10: 59-61, 143, 177-81, 265-67 \& 279-303; Le Mercier's Relation of the Hurons of 1638, in Relations 15: 67; Paul Ragueneau's Relation of the Hurons of 1649, in Relations 34: 113; and Jérôme Lalemant's Relation of the Hurons of 1642, in Relations 23: 185-87. The Jesuits also imagined that fornication was inspired by the devil. See, for example, J. Lalemant's Relations of the Hurons of 1642 and 1643, in Relations 23: 63; \& 26: 227-29. 
were considered as sacrifices to the devil. He wrote also that the entire occupation of chiefs was obeying the devil, in presiding over Hellish ceremonies as well as in exhorting young people to dances, feasts, nudity and lewdness. ${ }^{60}$ The difference between these two missionaries is that Father Brébeuf considered most feasts and rituals to be fake or superficial demonism while Father Lalemant did not question their authenticity. ${ }^{61}$

There have been two basic opinions about the Jesuit use of demonology. One is that the Jesuit missionaries were obsessed by demons and attempted to wage war against them, as can be seen in James Axtell's The Invasion Within and Bruce G. Trigger's The Children of Aataentsic. They note that the Jesuits employed a military metaphor to justify their missionary goals and methods, and deal with the missionary observations of demonism as faits accomplis that do not need to be examined. The other is that the Jesuits did not believe in native demonism, as Peter Goddard contends. He maintains that the use of the term 'devil' is the result of the linguistic deficiency of the priests, and that there was no actual demonism in New France.

This discussion, however, has not yet considered the readers in Europe, who were unable to share any physical American experience with the missionaries. From the Christian view that there is only one true God, all other reputed supernatural beings must be false or antiChristian. Thus, the identification of native divinities with demons came naturally to a Christian perspective. Christians believed that evil spirits could take possession of a person and that the removal of these unclean spirits by exorcism was a priestly function.

Although demons most probably existed, outside Christendom, predominantly in the Euro-Christian belief and rhetoric of the missionaries, demonism helped these Jesuit reporters to explain naturebased and non-Christian rituals dealing with evil spirits in a way

${ }^{60}$ Father Lalement's criticism was common to seventeenth-century religious zealots of the Roman Catholic faith, including Jesuit missionaries. They believed that the spirit and the physical desires were in conflict with each other and that the pious had to subjugate the desire for physical comfort and gratification. See Peter Moogk, La Nouvelle France: The Making of French Canada-A Cultural History (East Lansing: Michigan State University Press, 2000), 253-56.

${ }^{61}$ This paragraph is based on Jean de Brébeuf's Relation of the Hurons of 1635, in Relations 8: 123; Brébeuf's Relation of the Hurons of 1636, in Relations 10: 18589; Jérôme Lalemant's Relation of the Hurons of 1639, in Relations 17: 153-55; and Lalemant's Relation of the Hurons of 1642, in Relations 23: 185-87. 
comprehensible to European readers in the pre-scientific seventeenth century. Demonism was not alien to the knowledge of Christians in Europe. Simultaneously they made use of the concept of demonism in order to demonstrate the need for Christian missionaries who, in the name of God, would combat the devil in New France. ${ }^{62}$ This Ignatian military metaphor was the same with the Iberian references to demonism in Japan.

\section{b. The Social Structure}

The Amerindian social structure, especially of the Huron, Innu and Algonquin peoples, was as important a theme as their spirituality. As in Japan, power and authority seem to have been the basic ways for the Jesuit analysis in New France. Whether in Japan or in New France, or even in other colonies probably, the believers in authoritarianism tended to seek out leadership and attempt to influence most societies through those leaders. The frequent references to native headmen and councils were made from this perspective. The names of native chiefs included, for example, Membertou, a Mi'kmaq chief mentioned by Father Biard; Makheabichtichiou, an Algonquin chief mentioned by Father Le Jeune; and Aenons and Anenkhiondic, Huron chiefs referred to by Father Brébeuf. ${ }^{63}$ Among them, the description of Huron headmen was the most detailed, for the Huron mission was the first mission established in native country well to the west of the French settlements along the Saint Lawrence during the first half of the seventeenth century.

Through an analysis of the Huron chiefs, the Jesuits seem to have tried to figure out whom to approach or where to find influential authority. Father Brébeuf paid special attention to the old men in a village, who determined all matters and advised their people on how to do everything. He also recognised two kinds of chiefs. One kind was a war chief. The other kind was a sachem in charge of the affairs of state,

${ }^{62}$ James Axtell, The Invasion Within (New York \& Oxford: Oxford University Press, 1985), 91-94; Trigger, The Children of Aataentsic, 503; and Peter A. Goddard, 'The Devil in New France: Jesuit Demology, 1611-50', in The Canadian Historical Review 78 (1997): 40-62.

${ }^{63}$ Pierre Biard, to Christphe Baltazar, provincial of France, in Paris, from Port Royal, 10 June 1611, in Relations 1: 155, 165 \& 177; Paul le Jeune's Relation of 1637, in Relations 11: 149-83 \& 241; and Jean de Brébeuf's Relation of the Hurons of 1636, in Relations 10: 231, 235 \& 303. 
such as feasts, dances, games, lacrosse matches and funeral ceremonies. There were as many kinds of chiefs as of tribal affairs. Certain chiefs held their pre-eminence because of their intellectual superiority, popularity, wealth, eloquence, generosity, courage and wise conduct. Father Jérôme Lalemant learnt in 1639 and 1642 that chiefs were responsible for making announcements and managing ceremonials, which included dances, feasts and other performances. ${ }^{64}$

The Jesuit reporters also referred to councils, in which they seem to have tried to locate power. According to Father Brébeuf, power was manifested in the chiefs house where the council was held. Father Le Mercier noted, for example, that the council of war was held in the house of the war chief, and the council for the affairs of the country or the observance of law and order was held in the council house, which was probably the civil chief's dwelling. Yet the missionaries recognised that the village government was a civil one and had only partial power over people. The chiefs did not govern their subjects by means of command and absolute power, nor had they any force at hand to compel people to their duty. The council's rôle was instead to represent what was to be done for the good of the village or of the entire country. ${ }^{65}$

\section{Jesuit Biases in Interpreting Non-Christian Cultures}

Of course European priests were not the only people who were influenced by their own culture and religion. Yet in a comparative consideration of Iberian and French Jesuits, it seems clear that the Jesuits in New France described native culture in their own ideological way. The biases of the European missionary correspondents are difficult to identify within the Canadian historical framework based solely on the reading of colonial French missionary accounts. First, the Jesuit observations and interpretations of non-Christian peoples are more restricted and distorted by a wilful manipulation of information as well as by the limitation of their cultural scope. The written observations represent what image and idea the missionaries wished their readers

\footnotetext{
${ }^{64}$ Jean de Brébeufs Relation of the Hurons of 1636, in Relations 10: 15, 229-31; Jérôme Lalemant's Relation of the Hurons of 1639, in Relations 17: 129; and Lalemant's Relation of the Hurons of 1642, in Relations 23: 185.

${ }^{65}$ Jean de Brébeuf's Relation of the Hurons of 1636, in Relations 10: 233-35 \& 261-63; and Le Mercier's Relation of the Hurons of 1637, in Relations 13: 59.
} 
to hold about the indigenous people and their culture, and not what they actually were. The Jesuit annalists manipulated their observations of Amerindians for many possible reasons. For example, they seem to have used the correspondence to criticise other missionary groups that preceded them. For this purpose, native people with whom non-Jesuit missions had dealt were depicted as too barbaric to appreciate Christianity. The Relations were also tools for justifying their choice of missionary subjects, who were described as superstitious and thus needing Christian education. When placed within the range of Jesuit activity, those people who had once been barbarians under another missionary order were deemed to be qualified for Christian instruction.

The Euro-Christian cultural framework employed for interpreting native culture was first restricted by the cultural framework of priests, and then further distorted by the personal priorities of reporters. The missionaries interpreted Amerindian culture from within a EuroChristian value system. What they, as Christians, could not accept was elucidated negatively, and what they intended to accept as a potential hint for becoming Christian was recounted positively.

Second, the Euro-Christian biases and the observational or interpretive mistakes can be attributed to the missionaries' failure to understand the native culture in a native way, and in their misconception that they understood it well. The Iberian experience in Japan helps to affirm that the French missionaries relied heavily on their own existing cultural framework to understand foreign customs, especially beliefs. Even though they were aware that the native beliefs were myth and superstitions rather than religion, the Jesuits still employed Euro-Christian religious concepts in interpreting them. Whenever they could not understand the spiritual custom, they supplemented the mystery with superstitions and demonism as the easiest explanation.

The Jesuits were diplomatic enough to search for power and authority. These two aspects were important for them to find their potential patrons and to figure out whom to approach first. The Jesuit reports on Japan and New France are full of accounts of negotiations with influential men. Their analysis of the Amerindian social structure was directed pragmatically towards this strategic end. The priorities of the French Jesuits therefore limited missionary interpretations. For example, they did not explain why native authority and power were less effective than they needed them to be for spreading Christianity.

Considering both Iberian and French correspondents, however, the Jesuit reporters seem to have adjusted their expressed impressions 
according to the cultural and linguistic comprehension of the readers in their home country. When the priests wrote of their experience, they had to decide what to mention and how to describe it. What the evangelists saw and learnt may have been interpreted better in their own minds than in their written accounts that were culturally translated for a French mentality.

Third, the Iberian mistakes will lead to alternative interpretations, or hypotheses, of Amerindian culture. The cultural framework that the French Jesuits forced upon their interpretation of the native religion helped them to understand it, but at the same time it helped them to ignore differences of each element. The native religion that the Jesuits claimed to have discovered may not have been a coherent religion and may have been instead a series of independent beliefs and fables that were not necessarily relevant with one another. As was the result in Japan, the French Jesuits' academic achievement is that they reconstructed, for the imagination held by their European readers back home, a Jesuit version of Amerindian religion that had perhaps never existed as the systematical counterpart of their Euro-Christian religious concept.

There may be alternative interpretations when the Euro-Christian biases are considered in the Jesuit descriptions. For example, just as the concept of the Creation is alien to Buddhism, the Amerindian Creator may not have been an important component in the Huron belief in spirits. The Creator was not an object for religious worship. There was no 'Heaven' in indigenous beliefs. The native notion of the soul and its immortality was different from the Christian idea, and may have been something like eternal spirits that were believed to move from one body to another in a single secular world that lacked a Heaven. The concept of manitou or oki may have been related to these eternal spirits although the missionaries did not even hint at the connection between them. The indigenous people believed in supernatural powers and called them 'manitou' or 'oki', but they should not be connected immediately with the deity that was equivalent to the opponent to the Christian God. The native manitou or oki could be both good and bad, and the notion of devils or demons did not exist among the Amerindians before the mission. 


\section{CHAPTER THREE}

\section{PREACHING, WINNING CONVERTS AND EDUCATING THEM: EVOLVING MULTIFACETED STRATEGIES}

Preaching the Gospel to non-Christian people with the aim of converting them to Christianity was the fundamental rôle of missionaries. Interpreting how the multifaceted strategies of the Jesuits evolved over time presents its own problems. In Japan, the Jesuits constantly revised their methods throughout the second half of the sixteenth century. The more they understood local people, the better they became at gaining converts. The same can be said of the French missionaries in New France in the seventeenth century. As they became acquainted with the local people, their educational methods improved, resulting in more converts.

For a better understanding of the evolution of strategies of the Christian mission in New France, one needs to place it in a longer and broader perspective. In other words, one should also investigate the activities of Jesuit missionaries who were at work a half century earlier outside North America. When the Jesuit missions began in North America, the priests had already established some of their methods based upon two things: the initial plan for founding the Jesuit order; and the order's experience in other non-Christian regions throughout the world. Comparing the methods used in New France with the approaches undertaken by predecessors, such as those in Japan, will demonstrate the various approaches that served as the prototypes for French missionary strategies.

In order to understand this evolution in methods, it is important to address two issues. First is the question of whether or not one should label the Franciscan missionaries cultural absolutists, and whether or not one should label the Jesuit missionaries cultural relativists. The second issue is whether the Jesuits approached the local population using one method only. Or did they use a variety of methods, separate yet interconnected? If they used one single method, did the Jesuits then pick and choose certain individuals whom they wanted to convert? Also to be kept in mind is how missionaries modified their singleminded method over time. On the other hand, if the Jesuits were using a multifaceted or parallel approach from the outset, they must have 
envisaged two target age groups: children and adults, as well as two genders: male and female. If that assumption is correct, the Jesuits may have attempted to interconnect all these groups throughout the contact periods. Because a multifaceted approach is by its very nature broader and more inclusive, there was no need to shift approaches when dealing with potential converts to Christianity. With these two issues in mind, the earlier evolution in Japan will be used here as a basic evangelistic experience to be learnt by later missionaries, or in order to discuss the later development of multifaceted strategies in New France.

\section{A. JAPAN}

\section{Missionary Methods in Japan}

\section{a. Early Cultural Accommodation and Father Francisco de Xavier}

When Father Francisco de Xavier opened the mission to Japan, the first method he developed was a culturally accommodative, if imperfect, approach to individuals. His cultural adaptation was limited to preaching without using European languages or enforcing them upon Japanese neophytes. And yet this attempt is worthy of mention as an initial step towards the cultural accommodation the Jesuits developed through the second half of the sixteenth century. Discussion of Father Xavier's initiatives when preaching in Japan will require brief consideration of his experience in India in the 1540s, since his approach was based on his own soul-searching about his experience in India. Since most missionaries, including Father Xavier, were unable to comprehend Tamil, a local Indian tongue, all their communication with local people was conducted through native interpreters. The missionaries were not familiar with Indian customs, and thus they failed to see that people of India comprehended little of what the Jesuits were teaching. Of course, the priests failed to comprehend the answers given by the Indians, and the priests only half understood what the interpreters were saying. Because the people had to learn prayers that they did not fully understand, they were baptised without a deep knowledge of Roman Catholic doctrine. ${ }^{1}$

${ }^{1}$ Kishino Hisashi, Zabieru to Nippon (Tokyo: Yoshikawa Kôbun-kan, 1998), 93. 
This poor communication with East Indians made Father Xavier pessimistic about the future of the Indian missions. In his correspondence of 1549, three months before his party left for Japan, he pointed to the negative characteristics of the Indian population, whom he considered unsuitable to become Christians. Because Father Xavier preached only in Portuguese or Spanish through interpreters, he found it difficult to make himself understood to a people who, he realised, did not know God and did not listen to Christian reason because of ingrained and barbarous habits of living in sin. Father Xavier contended that the Society of Jesus could in no way be perpetuated by Indians alone, for he believed that they would remain Christians only as long as the European missionaries should remain in India. ${ }^{2}$

The effort and time spent to learn Tamil by one of his brethren inspired Father Xavier to believe that the Japanese mission would be successful by communicating in Japanese to each individual. Father Henrique Henriques was the first missionary in India to learn to communicate in fluent Tamil. He baptised selected individuals by repeatedly preaching to them until they abandoned their Hindu religion. ${ }^{3}$ Father Xavier applauded Father Henriques as a virtuous and admirable person who knew how to speak and write Tamil. According to Father Xavier, because of Father Henriques's knowledge of the Tamil tongue, the Christian converts had a tremendous love for him and treasured him for his sermons and speeches given in their own language. Father Xavier concluded that the efforts of Father Henriques had been the most successful in the mission because of his linguistic skill. ${ }^{4}$

Upon reaching Japan, Father Xavier made it a priority to learn the Japanese language and to understand this non-Christian society and culture so that the Jesuits might produce pious Christians. In 1549, he wrote to Father Loyola from Cochin that he would report on Japanese customs and writing. In the same year, he wrote to Father Simão Rodrigues in Portugal that, after reaching the archipelago, he would find out what was written in the Japanese religious texts. ${ }^{5}$

${ }^{2}$ Xavier to Father Ignatius de Loyola, in Rome, from Cochin, 12 January 1549; in in M. Joseph Costelloe, SJ (trans.), The Letters and Instructions of Francis Xavier (St Louis, Missouri: The Institute of Jesuit Sources, 1992), ep. 70, pp. 215-23.

${ }^{3}$ Kishino, op. cit., 93-95.

${ }^{4}$ Costelloe, op. cit., ep. 70, pp. 215-23, esp. 221.

${ }^{5}$ Xavier to Father Ignatius de Loyola, from Cochin, 12 January 1549; and Xavier to Father Simão Rodrigues in Protugal, from Cochin, 20 Janaury 1549; in Costelloe, $o p$. cit., ep. 70 \& 73, pp. 215-23 \& 229- 33. 
Although Father Xavier was unable to make himself understood in Japanese during his brief stay of just over two years, his frequent references to his effort to learn Japanese and his detailed descriptions of the culture in his correspondence demonstrate a clear recognition of the importance of communicating in Japanese and of preaching Christianity in a way that was understandable to the people. For example, he asserted that if he and his brethren knew how to speak Japanese, many people would become Christians. He added that his party had already learnt to explain the Ten Commandments in Japanese. In his correspondence, he also gave a full description of Japanese temples and Japanese habits as though they were the keys to finding appropriate ways to explicate religious terms in Japanese. ${ }^{6}$ Consequently, except for those who had not yet learnt enough Japanese, the Jesuit missionaries followed Father Xavier's advice and communicated with individual people in Japanese throughout the mission period in Japan.

\section{b. Hierarchical and Political Approach}

The other method that Father Xavier and other Jesuits applied to Japan was a community-based, political approach. Father Xavier, however, did not devise it from scratch after arriving in Japan, for he had already developed this mass-based and hierarchical approach in India in order to achieve large-scale, even if superficial, conversions to the faith. In 1545, for example, Father Xavier and his brethren baptised more than ten thousand people in one month. Native community leaders in southern India who wished to trade with the Portuguese were kindly disposed to the missionaries. Upon being invited to a village, Father Xavier and his companions would gather all the men and boys in one place. After preaching, the priests baptised them and then encouraged them to bring their wives and other family members to be baptised. ${ }^{7}$

Father Xavier applied this method to the missions in Japan. From the first contact in Japan, the Jesuits made it a practice to approach the rulers of local domains, or daimyô. The first task for Father Xavier, as a pioneer missionary to the country, was to secure the patronage of both the local and national rulers. His enthusiasm even made him seek an

${ }^{6}$ Xavier to his companions living in Goa, from Kagoshima, 5 November 1549; in Costelloe, op. cit., ep. 90, pp. 292-313, esp. 300.

${ }^{7}$ Xavier to his companions living in Rome, from Cochin, 27 January 1545; in Costelloe, op. cit., ep. 48, pp. 116-20. 
audience with the Japanese emperor in Kyoto even though there was no chance of such an audience, and this would not have been appropriate since the emperor had little power.

After introducing himself to local rulers, Father Xavier sought to obtain permission to preach to the residents in their fiefs. At the second audience with Ouchi Yoshitaka in 1551, Father Xavier gave him expensive foreign gifts as the ambassador of the Indian Governor Garcia de Sá and on behalf of the Indian Bishop Juan de Albuquerque. The Father accordingly secured a residence for priests and obtained the authorisation for preaching in Ouchi's territory. ${ }^{8}$

The Jesuit missionaries emulated the approach of Father Xavier. In Kyoto, for example, in 1560, they obtained official permission for their preaching from Shogun Ashikaga Yoshiteru, and later from his successor Ashikaga Yoshiaki in 1569. ${ }^{9}$ In other regions of western Japan, the Jesuit fathers obtained the patronage of local daimyô, including the Takayama clan in Osaka as well as the Ômura and Arima clans, both in Hizen, the modern-day Nagasaki and Saga Prefectures. Their authorisation allowed the missionaries to preach to the daimyô's retainers, as well as to ordinary residents in their domains. With the support of central or local rulers, the missionaries tried to secure buildings for use as churches and more opportunities for their activity.

Father Luis Frois's advice to Father Melchior de Figuereido in Bungo seems to represent the basic idea of the Jesuit strategy for gaining converts in Japan. After approaching Oda Nobunaga and the Ashikaga shogunate in Kyoto, Father Frois assessed the Japanese power structure and recognised the importance of obtaining the patronage of the upper echelons of society. As Father Frois saw it, in order to gain evangelistic fruit among all echelons of Japanese society, the Jesuits needed to win the hearts of national and local rulers and, in turn, the rulers had to demonstrate to the lower classes their love of the missionaries and appreciation of the mission. Otherwise, noted Frois, the missionaries could never protect themselves from anti-Christian parties, including Buddhist priests. Without powerful patrons, the Christian

${ }^{8}$ Xavier to his companions in Europe, from Cochin, 29 January 1552; in Costelloe, ep. 96, pp. 326-343, esp. 332-33.

${ }^{9}$ José Wicki, SJ (ed.) Historia de Japam (by Luís Froís, SJ, 4 vols., Lisboa: Biblioteca nacional de Lisboa, 1976-84), primeria parte, capitulo 25 [Frois, Historia, part I, chap. 25, henceforth]; part I, chap. 86; part II, chap. 76; and Matsuda Kiichi \& Kawasaki Momota (eds.), Furoisu Nipponshi (12 vols., Tokyo: Chûô kôron-sha, 1977-80), part I, chaps. 25 \& 86; part II, chap. 76. 

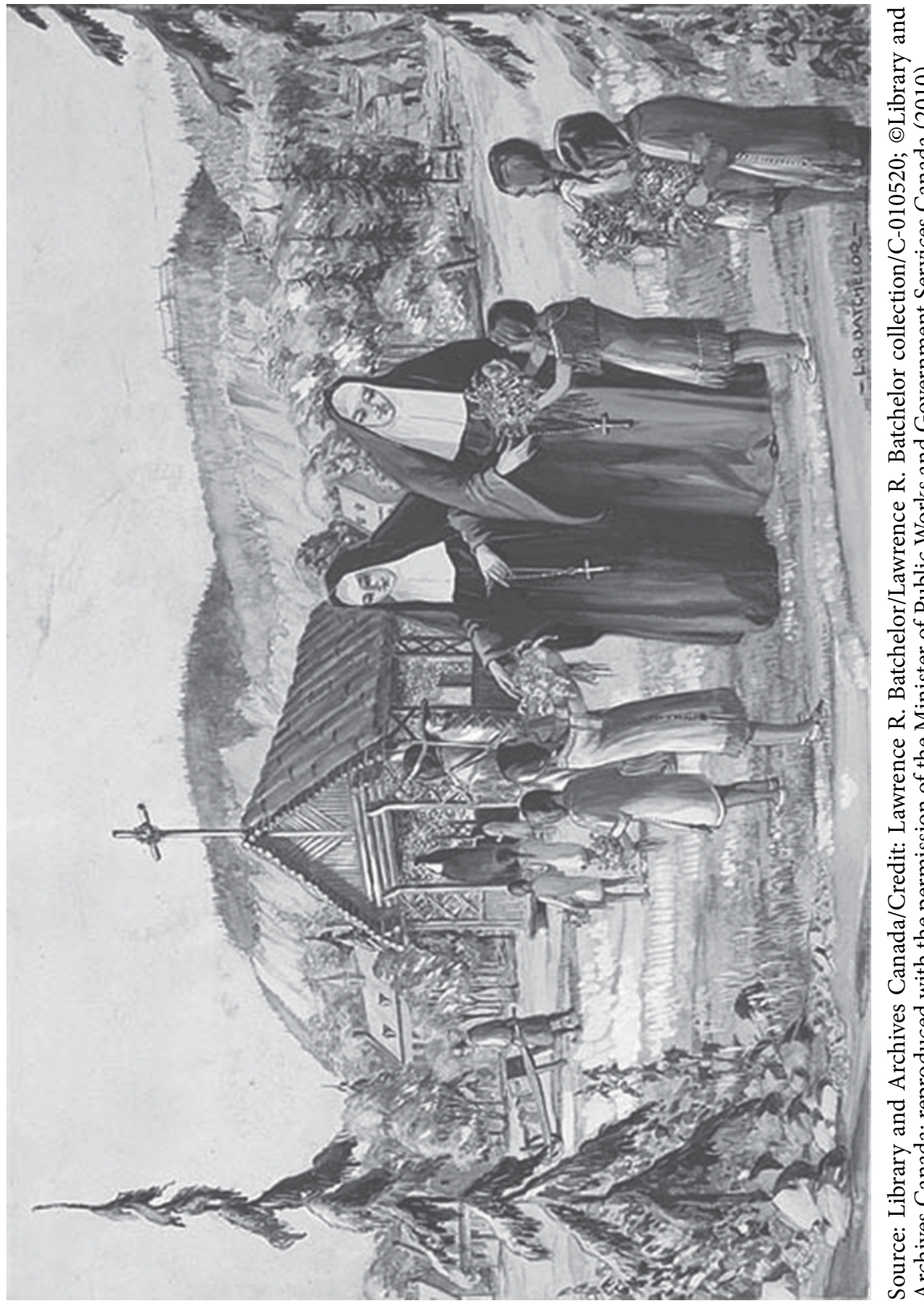

年



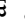

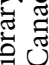

\&

寻

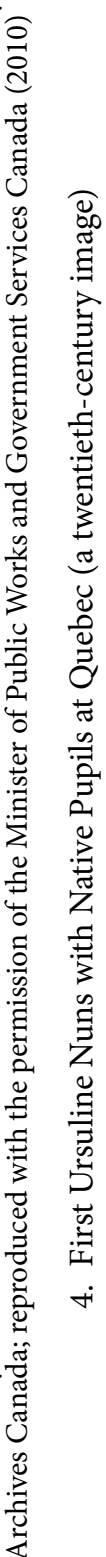




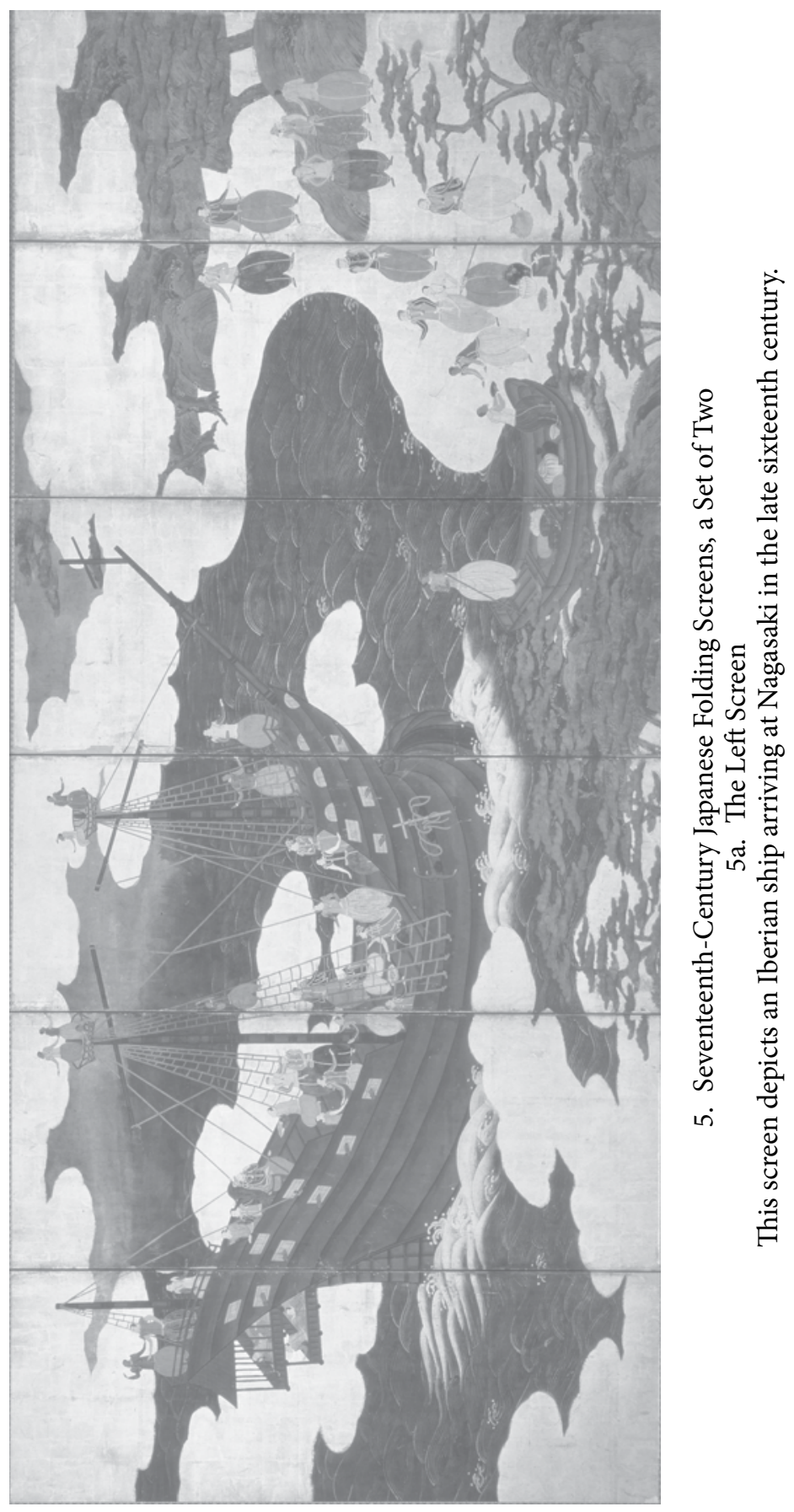




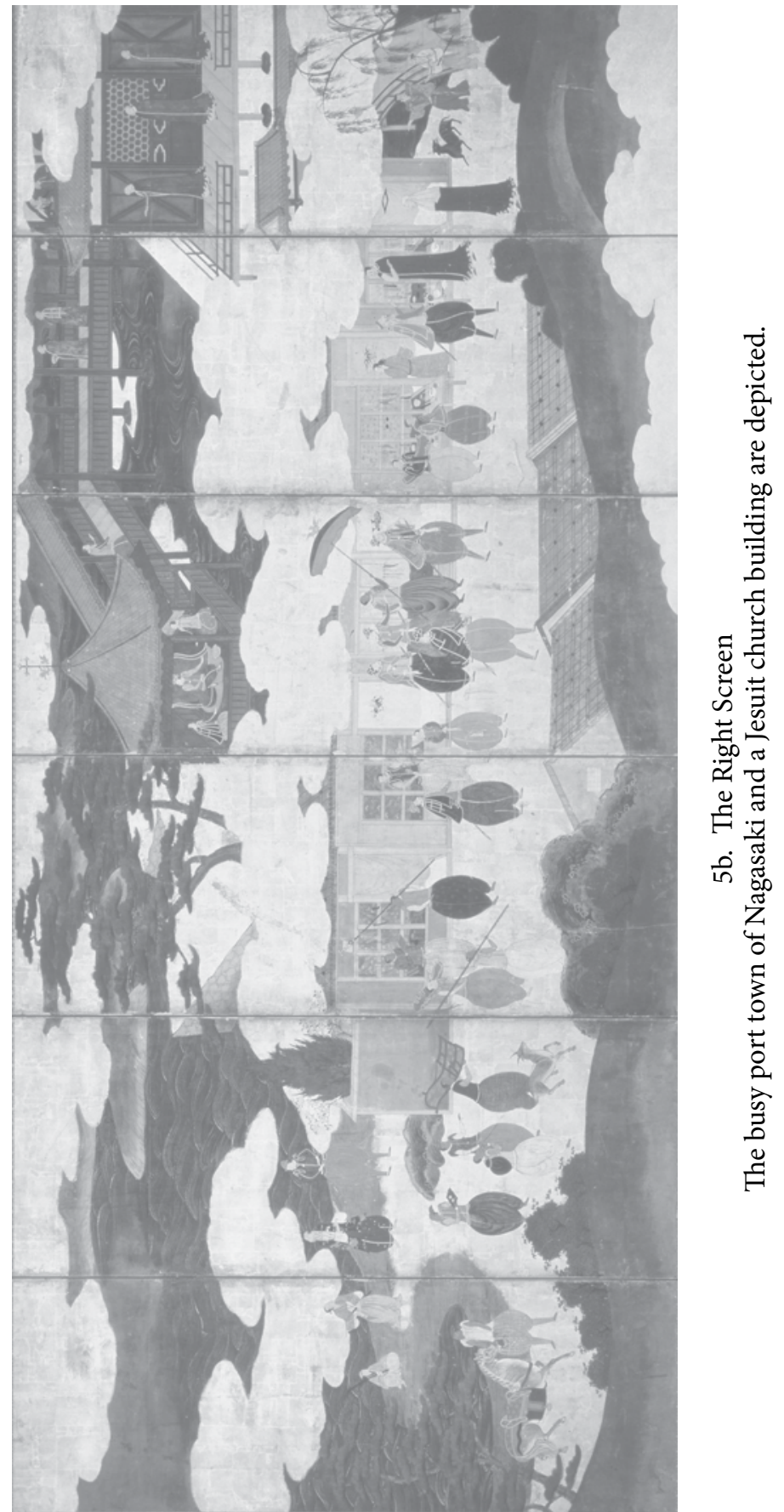




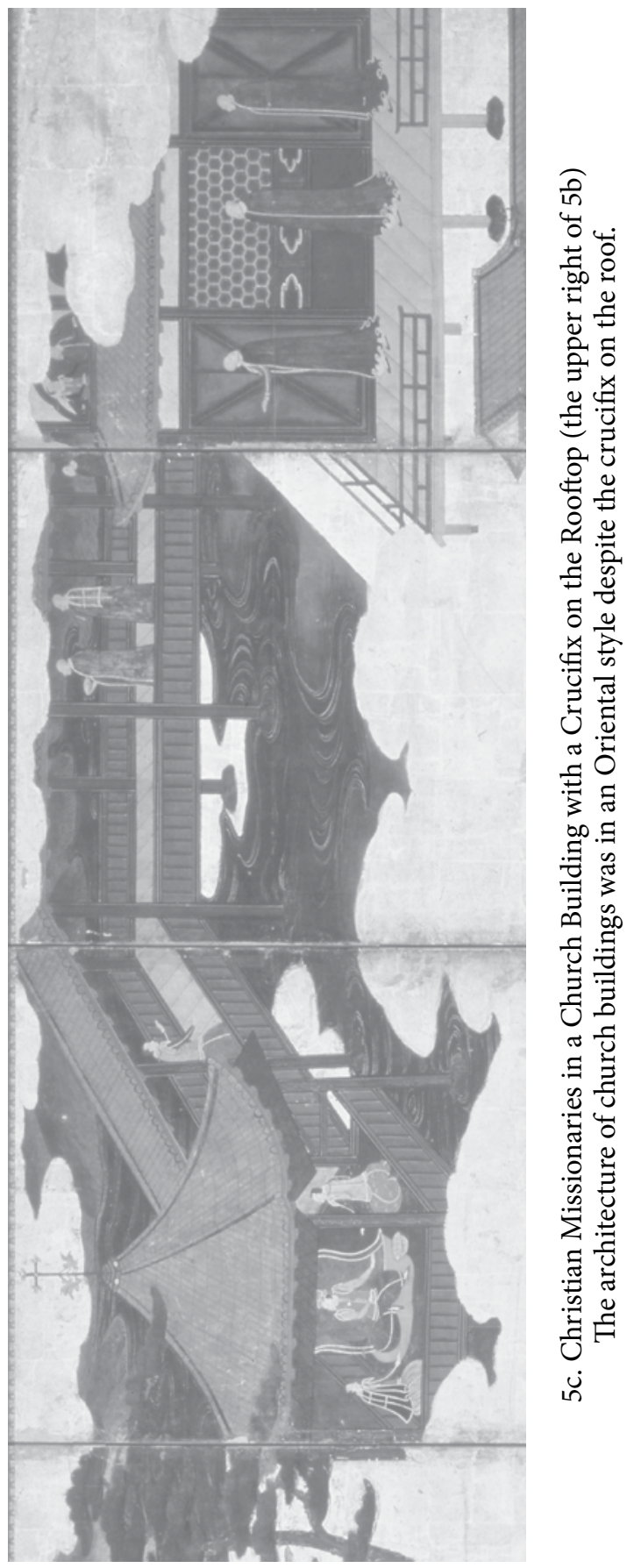




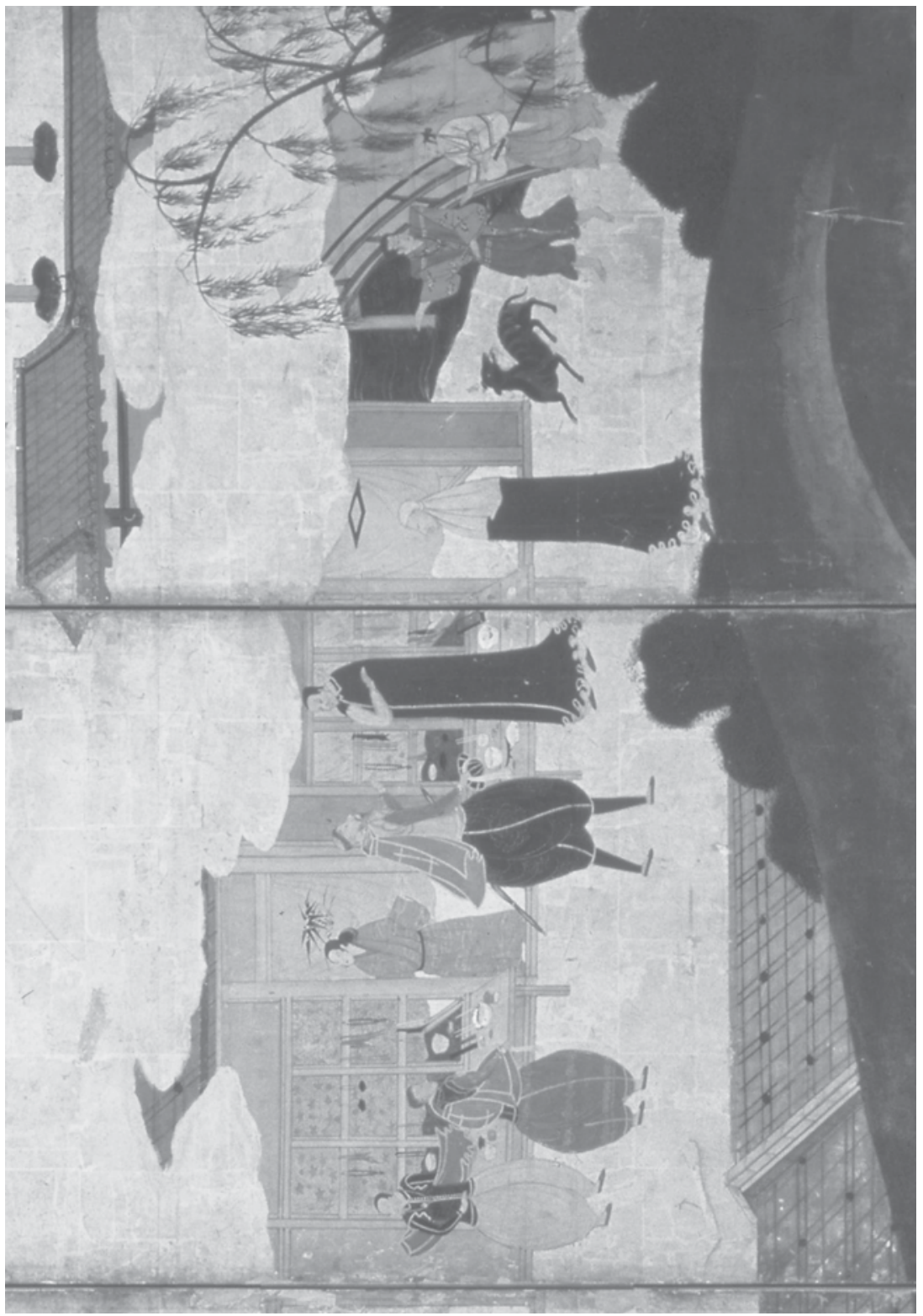

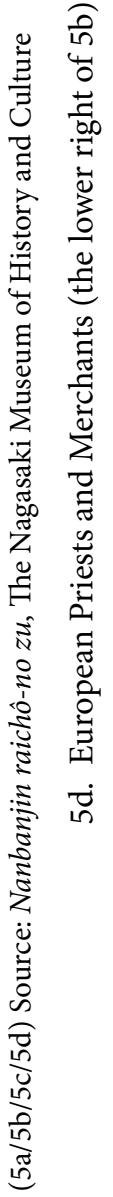


preaching would garner no social support. ${ }^{10}$ In this way, the vital matter in Japan was determining whom to approach for patronage rather than considering whether the missionaries should preach to the young or the old.

\section{c. Social Improvements}

In territories governed by pro-Christian daimyô, preaching was combined with philanthropy and education, which followed two important Jesuit principles of the mission. Social service was encouraged both by the Formulae of the Institute of the Society of Jesus and by the Constitutions of the Society. According to these constitutions, the Jesuits should propagate the Christian faith through missionary visitations, caring for the sick, teaching Christian doctrine to the young, and through works of charity. ${ }^{11}$ From a Japanese perspective, the philanthropy carried out by the missionaries and their converts was also a valuable service and a motive for baptism among the ordinary population of all ages and both genders especially because the civil war had left them destitute.

\section{(1) Philanthropy}

From the commencement of the missions, the Jesuit correspondence mentions cases of almsgiving guided by missionaries and organised by local residents. In 1554, the Jesuits decided to provide the residents of Yamaguchi with monthly food rations after preaching about the Ten Commandments. In Bungo under the rule of the Ôtomo clan in the late 1550s, the local Christian church collected donations from those who attended Sunday Mass so that priests and their Japanese assistants might later preach to and help the sick and destitute. By 1560, under the direction of Father Cosme de Torres, who succeeded Father Xavier as vice-superior, the Funai church in Bungo established

${ }^{10}$ Luis Frois to Melchior de Figuereido in Bungo, from Kyoto, 12 July 1569; in Matsuda Kiichi et al (eds.), 3rd ser. of Jûroku-shichi seiki Iezusukai Nippon hôkokushû (Kyoto: Dôhô-sha, 1988-1998), vol. 3, pp. 329-47, esp. 341-42 [henceforth, Matsuda, Hôkokushû 3, 3: 329-47].

${ }_{11}$ 'Formulas of the Institute of the Society of Jesus' in John W. Padberg, SJ (ed.), The Constitutions of the Society of Jesus and Their Complementary Norms (Saint Louis: The Institute of Jesuit Sources, 1996), article 1; 'The Constitutions of the Society of Jesus' in Padberg, op. cit., part vii, chap. 4, article 9, paragraphs 650-51; and Joseph F. Conwell, SJ, Impelling Spirit (Chicago: Loyola Press, 1997), 163-82. 
a medical hospital and philanthropic confraternities ${ }^{12}$ called 'irmãos da misericordia', or 'Brothers of Charity'. In this way, the Jesuits had their Christian converts help their neighbours who were ill, injured or destitute. $^{13}$

This type of Christian community based on philanthropy was not unique to the towns of Funai and Yamaguchi. The Jesuits attempted to organise communities in other regions under the patronage of Japanese nobility. According to a record for the year 1565 on Hirado, ruled by the Matsuura clan, the missionaries organised a confraternity. Four secretaries were elected to collect donations and to take care of the destitute. There was another confraternity in Takayama of Settsu, ruled by Takayama Hidanokami, a pious Christian patron. In the 1570s, Lord Takayama promoted conversions to Christianity in his domain by arranging philanthropy. In other words, in the absence of a local missionary, he acted as the religious leader on behalf of the missionaries. In another piece of correspondence, Father Frois referred to Nagasaki, the domain of Lord Ômura Sumitada. In Nagasaki, which was ceded by this lord to the Jesuits in 1580, the Jesuits had local Christians build a leprosarium and a shelter to help the destitute in the surrounding areas. Father Frois commented that this service attracted the inhabitants of surrounding areas to Nagasaki, and helped the missionaries to win them to Christianity. ${ }^{14}$

(2) Basic Medical Care

Another charity that attracted people was basic medical service. The Jesuits worked through reciprocity. They exchanged medical knowledge with Japanese physicians, whom they welcomed as brethren. On the one hand, to save the patients who gathered at the missionary residence of Funai, for example, Father Torres learnt from a Japanese physician how to make Chinese-style medicines. On the other hand,

${ }_{12}$ Religious confraternities, or confrarias, usually existed for shared devotions for a particular saint, a member of a holy family, or a cult, e.g. the Immaculate Conception. Charity would be a secondary function.

${ }_{13}$ Pedro d'Alcáçova to his companions in Portugal, form Goa, 1554; Baltasar Gago to his companions in India, from Bungo, 1st November 1559; and Gonçalo Fernándes to an unknown addresse at the College of Coimbra, from Goa, 1st December 1560; in Matsuda, Hôkokushû 3, 1: 107-22, 285-97, \& 327-33.

${ }^{14}$ Juan Fernández to his companions in China, from Hirado, 23 September 1565; Luis Frois to an unknown addresse, from Usuki, 20 August 1576 [or 1577]; Father Frois's annual report of 1583 to the general superior, 2nd January 1584; in Matsuda, Hôkokushî 3, 3: 45-55; 4: 365-78; \& 6: 175-212. 
Brother Luis d'Almeida, who was well versed in European medicine, passed on his surgical techniques to his Japanese brethren. ${ }^{15}$

The possibility of receiving medical help provided a strong motive for the acceptance of Christianity. To care for the sick, the Jesuits ran a hospital in Funai under the leadership of Brother Luis d'Almeida. The hospital was sponsored by a local Christian community, Portuguese merchants and Lord Ôtomo Yoshishige. In the late 1550s, this hospital accommodated more than one hundred patients, in addition to ill or injured outpatients. ${ }^{16}$

Brother D'Almeida's devotion to surgery ended abruptly after July 1560, however, when the Jesuit headquarters' prohibition of 1558 on direct involvement in medical treatment reached Japan. From that point on, the European Jesuits no longer gave medical treatment at the hospital, which declined gradually under the sole management of Japanese physicians. ${ }^{17}$ In Japan, there were no further hospitals or clinics established by the Jesuits, except for some leprosaria. This 1558 shift from an emphasis on saving both lives and souls towards a focus on saving only souls determined some characteristics of the New France missions, as will be discussed later.

\section{(3) Elementary and Nursery Education}

The third type of social service offered by the Jesuits was in the sphere of education, which included two basic types of instruction. The first was rudimentary instruction explaining basic Christian doctrine and some non-religious subjects through basic Japanese-language instruction, even though the Constitutions of the Society provided that, because of the dearth of members, the Jesuits should give no elementary education to teach how to read and write. ${ }^{18}$ The second kind of education was to train future assistants and priests. Education was a fundamental activity for missionaries rather than a strategic creation of the Japanese mission. Yet it provided a framework for managing local Christian communities.

${ }^{15}$ Frois, Historia, part I, chap. 19; Matsuda \& Kawasaki, op. cit., 6: 200-06; and Baltasar Gago to the companions in India, from Bungo, 1st November 1559; in Matsuda, Hôkokushû 3, 1: 285-97.

${ }_{16}$ Baltasar Gago to the companions in India, from Bungo, 1st November 1559; and Aires Sanches to the companions in Portugal, from Bungo, 11 October 1562; in Matsuda, Hôkokushû 3, 1: 285-97; \& 2: 31-38.

${ }_{17}$ Higashino Toshio, Nanban'i arumeida (Tokyo: Kashiwa shobô, 1993), 171-72.

18 'The Constitutions of the Society of Jesus' in Padberg, op. cit., part iv, article 3C, paragraph 451. 
The Jesuits hoped that general instruction in the Christian faith would result in the formation of local religious groups of adults. There was one problem, however. Before the missionaries began tutelage of boys in Bungo, for example, the sons of newly-converted Christians were already commuting to Buddhist temples to learn how to read and write. To eliminate this Buddhist influence upon the children of neophytes, the missionaries had to provide a replacement for this traditional education. They did so by re-interpreting the Jesuit regulation that 'because of the lack of members these elementary subjects are not ordinarily taught'. ${ }^{19}$ Brother Juan Fernández, who worked in Bungo, stated that, from his own Christian standpoint in 1561, the boys studying at Buddhist temples learnt 'vices and evil habits'. The Jesuits, he continued, decided to have the children of their converts come to their residences instead so that they could teach them to read and write Japanese, in addition to Christian doctrine. In Kuchinotsu, in the domain of Arima, the missionaries had difficulty in persuading their congregation not to return to the service of Buddhist temples. To solve this problem, Brother Luis d'Almeida set up an elementary school in 1563 for the children of converts to learn both written Japanese and Christian doctrine. He concluded that, from that time onwards, former visitors to the church and their children who had been studying at Buddhist schools returned to the Jesuits. ${ }^{20}$

Passages in the Jesuit correspondence suggest that the missionary residence functioned also as a nursery for even younger children of both existing and potential adult converts. In 1561, for example, Brother D'Almeida referred to the childcare service on Ikitsuki Island, near Hirado. At the Jesuit residence, which could accommodate over six hundred visitors, Christians gathered every morning and evening to hear sermons. The Jesuits arranged a day-care service for the children of those converts who were working in the fields during the day. Another reference to Jesuit childcare is Father Frois's account of Takushima Island, also near Hirado. In 1564 Brother Fernández and Father Frois spent a year on the island. According to Father Frois, they were successful in winning converts by schooling the children of

19 Loc. cit.

${ }^{20}$ Juan Fernández to the Jesuit companions, from Bungo, 8 October 1561; in Matsuda, Hôkokushû 3, 1: 349-65, esp. 351-52; and Luis d'Almeida to the companions in India, from Yokoseura, 17 November 1563; in Matsuda, Hôkokushû 3, 2: 99-136, esp. 119-20. 
existing and potential adult converts. For teaching Christian doctrine, the missionaries not only gathered local teenagers in church in the evenings after their daily field labour, but they also had little children visit them twice a day, in the early morning and at noon. ${ }^{21}$

\section{d. Seminary Education}

The Jesuit education for Japanese children, which began in the early 1560 s, eventually led to the establishment of two seminaries, which were designed to train boys for the priesthood. These seminaries began as late as 1579 or 1580 under the leadership of Father Alessandro Valignano, the padre visitador who was in charge of the entire East Asian mission. One seminary was built at Azuchi, in the Oda clan's territory, in 1579, and the other was established at Arima, in the Arima clan's territory, in 1580. Select boys boarded with the missionaries and their assistants, away from their parents. This type of seminary was one of the first such institutions for non-European boys and became the prototype for the seminaries for native boys near the French settlements in seventeenth-century North America. It was also one of the prototypes for residential schools for Amerindians in nineteenth and twentieth century Canada.

Father Valignano hoped that these seminaries would strengthen Christian communities under the guidance of Japanese priests, rather than simply educating boys. In his report to the general superior in 1583, he discussed the need for a seminary in Japan. He listed three reasons for creating a seminary by following the examples of the Jesuits in Europe and India. First, the seminaries would prevent Japanese boys from becoming unruly and self-indulgent. Second, early education in Latin and other academic subjects would relieve the Japanese of ignorance and make them capable of becoming missionaries. Third, the Jesuits should eliminate the traditional Buddhist rôle in education, replacing it with Christian schooling. With these three reasons in mind, Father Valignano intended to train seminarians to become Jesuits or assistants.22

${ }^{21}$ Luis d'Almeida to Father Antonio de Quadros, the superior of the Indian mission, and other companions, from Bungo, 1st October 1561; in Matsuda, Hôkokushû 3, 2: 369-89; Frois, Historia, part I, chap. 52; Matsuda \& Kawasaki, op. cit., 9: 172-73.

${ }^{22}$ Matsuda Kiichi (ed.), Nippon junsatsuki (Tokyo: Heibon-sha, 1973), 77-80; based on Sumario de las cosas que pertenecen a la provincia de Japon y al gobierno della, compuesta por el P. Alexandre Valignano, Visitador de las Indias de Oriente dirigido 
There are two characteristics to note in the Jesuit plan for these seminaries. One is that the Jesuits did not teach Portuguese to seminarians despite their Portuguese royal patronage. Another is that Father Valignano intended to use the seminaries to gain the support of influential Japanese patrons if possible, just as his brethren in Europe used the Jesuit colleges for the same purpose. In the same report, he proposed that the seminaries should accommodate the sons or younger brothers of aristocrats, of domain rulers and of their vassals, should there be any extra time, funding, or personnel. For the Jesuits, therefore, securing local elite patronage was more important than bringing up future Japanese priests, for education was possible only with the support of the local nobility.

\section{e. Attempts at Baptism}

The Jesuits attached importance to post-baptismal preaching but only gradually did they emphasise pre-baptismal instruction. When early Jesuits began to work in the Japanese missions in the 1550s, their lack of command of Japanese forced them to depend on their Japanese assistants, who did the preaching. They were thus barely capable of confirming each proselyte's avowed comprehension of the faith and belief in it. Initially the only option was mass baptism without much instruction. Father Xavier, for example, reported that his party had conducted one hundred baptisms in Kagoshima, another one hundred in Hirado and more than five hundred in Yamaguchi during his two-year sojourn. ${ }^{23}$

Three decades later in 1583, as the superior of the Japanese mission, Father Valignano, proposed more systematic instruction before baptism. According to these instructions, candidates should be baptised after a seven-day period of instruction. In the first three days, priests were supposed to expound on two fundamental points: the salvation of souls through God; and the concept of the eternal soul. In addition, four days should be spent on further study of Roman Catholic doctrine. After this seven-day course, those who sought baptism were instructed to write several prayers in Japanese as prerequisites for

a N.P. Gen. Claudio Aquaviva, preserved in Biblioteca da Ajuda. Cód. 49-IV-56. ff. $55-114 \mathrm{v}, 116-145 \mathrm{v}$.

${ }^{23}$ Xavier to his companions in Europe, from Cochin, 29 January 1552; in Costelloe, ер. 96, pp. 326-343, esp. 330-35. 
baptism. Father Valignano admitted that, even after this type of baptismal instruction, a fresh convert would still need to be trained in a church to become a fine Christian. ${ }^{24}$

This training sequence indicates that the Jesuits spent less time preaching and training the congregation before baptism than Father Valignano had proposed. From another point of view, the instruction and standard for baptism grew strict enough for Japanese candidates to identify themselves as Christians or to distinguish themselves from Shinto or Buddhist believers. To confirm a candidate's faith in God, the missionaries either instructed or obliged neophytes to discard nonChristian icons and scriptures. ${ }^{25}$ By approaching communities rather than individuals, the evangelists were able to baptise from a few hundred to thousands annually at the respective local residences until the early seventeenth century. ${ }^{26}$

\section{The Jesuits and the Franciscans in Japan}

Thus, the Jesuit strategies for preaching and winning converts were not only based on the Society's Formulae and Constitutions but also on cautious observation of the complex situation of the mission in Japan. The Jesuits learnt some Japanese in order to communicate with converts. The only other option was to force these converts to speak Portuguese, which they did not even try to teach to their Japanese students. As a fundamental policy, the missionaries approached local

${ }^{24}$ Ibid., 74; Thomas Uyttenbroeck, Jûroku naishi jûshichi seiki no Nippon ni okeru Furanshisukokaishitachi (trans. Ishii Kengo, Tokyo: Chûo shuppansha, 1980), 56-57.

${ }^{25}$ Fernão Guerreiro, SJ, Relação anual das coisas que fizeram os padres da Companhia de Jesus nas suas missões do Japão, China, Cataio, Tidore,... Goa,... Cabo Verde e Brazil: Nos anos de 1600 a 1609... (1603-1611, three vols., 2nd ed., Coimbra \& Lisboa, 1930-42), tomo I, parte primeira, livro secundo, 69-164, edited in Matsuda, Hôkokush $\hat{u}$ 1, 3: 151-302, esp. 198, 213-214; Luis Frois's report of 1583 to the general superior, from Japan, 2nd January 1584, in Matsuda, Hôkokushû 3, 6: 173-212, esp. 197-99; and Frois to the general superior, from Nagasaki, 20 August 1585, in Matsuda, Hôkokush $\hat{u}$ 3, 7: 1-93, esp. 15-16.

${ }^{26}$ See Gaspar Coelho's report of 1588 to the general superior, 24 February 1589, in Matsuda, Hôkokushû 1, 1: 1-93, esp. 20-24; Coelho's report of 1589 to Alessandro Valignano, from Kadsusa, 7 October 1589, in Matsuda 1, 1: 113-138, esp. 125; Luis Frois's report of 1595 to the general superior, 20 October 1595, from Kyoto, in Matsuda, Hôkokushû 1, 47-88, esp. 69-70 \& 74; Luis Frois's report of 1596, from Nagasaki, 13 December 1596, in Matsuda, Hôkokushû 1, 125-271, esp. 147-48, 177-84, 191-95, 226 \& 261-62; Fernão Guerreiro, op. cit., tomo I, parte segunda, livro primeiro, 169-234, edited in Matsuda, Hôkokushû 1, 4: 67-172, esp. 83, 94, 99-100 \& 158-59; and Fernão Guerreiro, op. cit., tomo III, livro terceiro, 115-231, edited in Matsuda, Hôkokush û 1, 5: 121-299, esp. 223. 
rulers for patronage. Once they gained the daimyô's authorisation and sponsorship, they preached Christianity in Japanese to residents. The Jesuit schooling for young seminarians consisted of teaching Christianity and Latin along with basic subjects. These methods lasted under the Jesuit monopoly of the missions until the early 1590s.

One further point to note in this regard is that, whereas it was the Jesuits who followed the Franciscan mission in New France, it was the Franciscan friars who followed the model of the Jesuit mission in Japan. In 1584, four friars under Spanish royal patronage arrived at Hirado from Manila. They were welcomed by Lord Matsuura Shigenobu of Hirado, and then they returned to Manila and reported that the prospects for a successful mission were good. Again, in 1593, the Franciscan Father Pedro Bautista's party reached Japan, and began their Christian preaching the following year. ${ }^{27}$

The Franciscan approach to preaching was similar to the Jesuit one in terms of the above-mentioned hierarchical approach and social improvements. The Franciscans were wise enough to recognize that they were burdened with two disadvantages: They were foreign and they were in the minority. They quickly learnt to operate their own mission using many of the strategies developed by the Jesuits in Japan. Accordingly, unlike their compatriots in the Philippines who worked under the umbrella of Spanish colonial rule, the Franciscans in Japan did not attempt to impose themselves and their theology on the Japanese. The first task for the Franciscans was to obtain the patronage of Japanese rulers following the example of the pioneer Jesuits. As the Spanish emissary from Manila, Father Bautista managed to receive an audience with Toyotomi Hideyoshi, who controlled most parts of central and western Japan in the 1590s. Father Bautista also asked Hideyoshi for permission to stay in Japan as a missionary. Once the mission was authorised, or more to the point, once the Franciscan friars assumed that it was authorised, ${ }^{28}$ the Franciscans began preaching the Gospel in

${ }^{27}$ Pablo Pastells, SJ, Jûroku jûshichi seiki Nippon Supein kôshôshi (trans. Matsuda Kiichi, Tokyo: Taishûkan shoten, 1994), 07 \& 77-98.

${ }^{28}$ There was disagreement on the authorisation for the Franciscan mission. The Franciscan Father Bautista's interpretation of what the Friars had been granted by Hideyoshi was the sponsorship and authorisation of their sojourn as well as their evangelistic activity in Kyoto. The Jesuit Father Luis Frois reported later, in 1597, that Father Bautista had misinterpreted the message of Hideyoshi, who had really only given permission to the Franciscans to promote international trade. Father Frois believed that Father Bautista had been wrong because Hideyoshi gave the Jesuits the same 
their limited Japanese, assisted by their interpreters in Kyoto, Osaka and Nagasaki. In preaching and baptising people, they were assisted by Father Pedro Gómez, the Jesuit vice-superior of Japan. Thus, the Franciscans followed, from the outset, the existing guidelines established by Father Valignano. The Franciscans also began to found noviciates and hospitals in Kyoto. Despite a short break from 1597 to $1602,{ }^{29}$ the Franciscans succeeded in organising ten noviciates and seven hospitals from the 1590 s to the mid-1610s. ${ }^{30}$

Although the Franciscans followed the Jesuit model, there were some variations, at least initially. For example, the Jesuit Father Frois wrote in 1597 that the Franciscan Father Bautista had begun to preach openly in public in Kyoto even though the Jesuit activity had remained underground since Hideyoshi's proscription of Christianity in $1586 .{ }^{31}$ In order to claim that the Franciscans, but not the Jesuits, were responsible for causing the execution of twenty-six Christians in 1597, ${ }^{32}$ Father Frois blamed Father Bautista's failure to obey the orders of Hideyoshi. It must be said that, only after having won converts during the first stage of the missionary work, the Franciscans would have been able to proceed to the second stage, which involved assisting those lay Christians in order to win more converts, as did the Jesuits in their underground missions. Thus, by beginning only with underground activity, the Franciscans could never have been able to expect missionary success.

order-that the European visitors were to promote international trade only. Father Frois's idea was that Hideyoshi only overlooked the Jesuit priests' stay in Nagasaki for promoting international trade and had not withdrawn his anti-Christian proscription issued in 1586 before the arrival of Father Bautista. For Father Frois's opinions, see his own report on the twenty-six martyrs in Nagasaki in 1597, made to the general superior at Rome (from Nagasaki), 15 March 1597, in Matsuda, Hôkokushû 1, 3: 1-82, esp. 6-9; and Michael Cooper, Tsûji Rodorigesu (trans. Matsumoto Tama, Tokyo: Hara shobô, 1991), 102-103. For Father Bautista's perspectives, see Uyttenbroek, op. cit., $33-35$ \& 42-44.

${ }^{29}$ In 1597, Hideyoshi removed all eleven Franciscan missionaries from Japan by executing six and deporting five. Hideyoshi died in 1598. Tokugawa Ieyasu was successful in reorganising the power structure of Japan by 1603 .

${ }^{30}$ Uyttenbroeck, op. cit., 33-63.

${ }^{31}$ Frois's report on the twenty-six martyrs in Nagasaki in 1597, made to the general superior at Rome (from Nagasaki), 15 March 1597, in Matsuda, Hôkokushûu 1, 3: 1-82, esp. 6-9; and Michael Cooper, op. cit., 102-103.

${ }_{32}$ Twenty-six Christians, mainly Franciscan missionaries and their Japanese assistants, who had been arrested in Kyoto and Osaka by the order of Toyotomi Hideyoshi in December 1596, were taken to Nagasaki and executed there in February 1597. 
Another difference was that the Franciscans initially walked barefoot and dressed in rags in order to fulfil their vow of poverty. They did so in spite of the fact that the Jesuits had already adopted the Japanese clothes well before the $1590 \mathrm{~s}^{33}$ However, this does not mean that the Franciscans imposed their choice of attire on their converts. Rather, they dressed in rags as a way of letting the Japanese know that another Roman Catholic religious order had arrived. Therefore, this contrast in clothing style, between the Franciscans and the Jesuits, does not represent any differences between the two orders, as far as cultural tolerance is concerned. Moreover, these distinctly different styles take nothing away from the argument that there was a continuity of methodologies between the Jesuits and the Franciscans. ${ }^{34}$

\section{Hypotheses for New France}

The case of the missionary strategies in Japan yields two general hypotheses. First, it is inappropriate to consider the Franciscans to have been different from the Jesuits in terms of the instillation of EuroChristian culture. Despite their poor adaptation to Japan in the early stage, the Friars from the Spanish colony of the Philippines followed, to a large degree, the missionary conventions that the Jesuits had devised through their forty-year experience in this archipelago.

Second, in the Jesuit strategy, no priority was given to the conversion of adults or youth. Converting the general adult population and educating children were two parallel activities with differing motives. Notwithstanding the fact that there was some overlap between these activities, the former was essential for establishing a Christian community and the latter was originally based on the instructions of the Ignatian Formulae and Constitutions. It is now possible to examine these hypotheses with regard to the missionary experiment in New France.

${ }^{33}$ Neil S. Fujita, Japan's Encounter with Christianity (New York \& Mahwah, N. J.: Paulist Press, 1991), 132-33.

${ }^{34}$ Cf. Fujita, loc. cit. 


\section{B. New France}

\section{The Question of Cultural Absolutism and Relativism}

\section{a. The Franciscan Missions}

The Jesuits succeeded the Friars in New France. True, the Jesuits did arrive in the French colony of North America earlier than the Franciscans. Yet their missions ended within three years when the French abandoned Acadia in 1613. Samuel de Champlain managed to raise funds in 1614 to bring Récollet Franciscans inland to the Saint Lawrence Valley, west of Acadia. They reached Quebec the following year. ${ }^{35}$ It was ten years later, in 1625 , that the Jesuits finally joined the mission as ecclesiastical reinforcements for New France.

In recent Canadian historiography, several scholars have dealt with the differences in these two religious orders' approaches to evangelistic activity. These differences have often been attributed to the separate origins of each missionary organisation. One common opinion, espoused first by Bruce Trigger in 1976, was the contrast between the cultural absolutism of Franciscans and the cultural relativism of Jesuits. The Franciscans, contended Trigger, believed that the indigenous peoples, in order to become true Christians, should become French in language and culture. The Jesuits, on the other hand, rejected this policy of cultural imperialism as a necessary condition for the Amerindians to be evangelised. Trigger affirmed that this policy difference originated in the ideological distinction between these missionary organisations, and had nothing to do with the experimental transition from Franciscans to the Jesuits. His opinion has gained the support of many contemporary scholars ever since, including John Webster Grant in 1985, Charles Principe in 1987, Roger Magnuson in 1992, Anya Mali in 1996 and Carole Blackburn in 2000. ${ }^{36}$

${ }^{35}$ W.L. Grant (ed), Voyages of Samuel de Champlain, 1614-1618 (New York: Charles Scribner's Sons, 1907), 270-271.

${ }^{36}$ Bruce G. Trigger, The Children of Aataentsic (Montreal \& Kingston: McGillQueen's University Press, 1976), 376-81 \& 467-69; Trigger, Natives and Newcomers (Montreal \& Kingston: McGill-Queen's University Press, 1985), 200-02; John Webster Grant, Moon of Wintertime (Toronto: University of Toronto Press, 1984), 38 \& 46; Charles Principe, 'Les Jésuites missionnaires auprès des Amérindiens du Canada' in G. Demerson et al, Les Jésuites parmi les hommes aux XVIe et XVIIe siècles (Association des Publications de la Faculté des Lettres et Science Humaines de Clermont-Ferrand, 1987), 309-20, esp. 317; Roger Magnuson, Education in New France (Montreal \& Kingston: McGill-Queen's University Press, 1992), 19-20; Anya Mali, 'Strange Encounters: 
An opposing interpretation focusses on the cultural argument that the missionaries' approach to foreign cultures developed continually throughout the seventeenth century, irrespective of the difference in religious orders. Cornelius J. Jaenen, for example, maintained in 1976 that the Jesuits perpetuated the Franciscan missionary policy and gradually adapted their approach in their negotiations with indigenous people. Along the same lines, in 1984 James Axtell argued that the Jesuit programme of conversion resembled the Franciscan programme of cultural assimilation throughout the 1630s. Then in the 1640s, the Jesuits turned to establishing native reserves, where they tried to settle down nomadic peoples. ${ }^{37} \mathrm{Few}$ other historians support these contentions.

To date, there has been little discussion and thus no compromise between these schools of thought. Among Canadian historians, it is almost impossible to determine whether the difference of attitudes was the result of a distinction between the principles of the two ecclesiastical orders or of an evolution in their strategies. A broader perspective that considers the relationship between the Franciscans and the Jesuits half a century before in Japan could well help to clarify this question.

It is an oversimplification to attribute methodological differences to the stated goals and ideals of religious bodies. Both the Jesuits and the Franciscans in Japan were clever diplomats who were able to analyse their political situation in a foreign land and to figure out the best possible approach. The Franciscans in Japan carefully adopted a method based on the accumulated experience of the Jesuits and were in no way culturally more aggressive than the Jesuits. In other words, the putative contrast between the culturally aggressive Friars and the culturally accommodative Jesuits needs to be reconsidered.

No matter how Eurocentric from a cultural perspective the missionary strategy of the French Friars may have been, it was not because they were Franciscans but because they were the pioneer missionaries with little practical experience. The only strategy initially open to them was to encourage indigenous people to live in the French settlement so that they might learn to communicate in French and learn European customs.

Missionary Activity and Mystical Thought in Seventeenth Century New France', History of European Ideas 22 (1996): 67-92; and Carole Blackburn, Harvest of Souls (Montreal \& Kingston: McGill-Queen's University Press, 2000), 130-31.

${ }_{37}$ Cornelius J. Jaenen, The Role of the Church in New France (Toronto: McGraw-Hill Ryerson, 1976), 22-30; and James Axtell, The Invasion Within (New York \& Oxford: Oxford University Press, 1984), 59-64. 
Only this enterprise seemed possible for them at this initial stage although it proved impossible later.

This limited capacity of the early mission to communicate in Amerindian languages can be illustrated by its attempt at education. The education that Franciscans introduced to native boys in 1620 at Notre-Dame-des-Anges, near Quebec, followed the assimilation model, since there was not yet an Amerindian prototype for formal education. In 1616, the Friars endeavoured to bring young Amerindians to their French settlement, expecting that they would grow up to embrace Christianity, as well as French culture. Ultimately the missionaries hoped, these boys would help the missionaries promote Christianity. Usually one or two boys stayed with them, and they dispatched a total of six boys to France. ${ }^{38}$ Although this assimilation policy may have been overly culturally aggressive, it was the only approach that seemed initially possible for pioneer missionaries, no matter whether they were Franciscans or of any other religious order.

Four factors drove the small group of Franciscans in the Saint Lawrence towards what Trigger and other historians consider cultural absolutism. First, the human resources of their mission were insufficient to initiate an active mission. From 1615 to 1629, the number of Friars, including lay brothers but excluding domestic assistants, was normally three or four and at no time more than eight. ${ }^{39}$ In fact, in the autumn of 1616 there were only two Friars. The greatest number in any one year was eight, and that was in the summer of 1624. Even at this time, only four missionaries stayed in North America throughout the whole year. In 1615, the first four Franciscans arrived in Quebec. These four missionaries did not remain in New France throughout the 1610s and 1620 s, for they had to secure recruitments and financing back in their home country, and thus they made several trips to France. Although more than ten missionaries reinforced the original four, many of them seceded from the Canadian missions within one to three years and contributed little to long-term missionary aspirations. ${ }^{40}$

${ }^{38}$ Chrestien le Clercq, Premier établissement de la foy dans la Nouvelle France (2 vols., Paris: Auroy, 1691), vol. 1, 99 \& 257; and Trigger, The Children of Aataentsic, 378-80.

${ }^{39}$ Cf. Magnuson, op. cit., 16-17; Trigger, Natives and Newcomers, 200-01; and Axtell, op. cit., 55.

${ }^{40}$ This paragraph is based on George M. Wrong, 'Introduction' for George M. Wrong (ed.), The Long Journey to the Country of the Hurons (by Gabriel Sagard, Toronto: The Champlain Society, 1939), i-xlvii, esp. xxviii-xxxvi; G.M. Dumas, 'Pacifique Duplessis', 
Second, as pioneer missionaries, the Franciscans were slow to learn native tongues and thus had difficulty in teaching them to their colleagues. With some exceptions, such as Fathers Le Caron and Viel, most Friars went back to France before they attained proficiency in an Amerindian language.

Third, because Lieutenant Samuel de Champlain facilitated the founding of the Franciscan mission and was its most vital supporter, the Friars were obliged to go along with his grand plan for colonisation. The basic Franciscan idea for Christianisation was to teach native people how to live in a Christian way and according to the principles and laws prescribed by God and by the Roman Catholic Church. Father Joseph le Caron's party preached this message at least to one Huron man during the mission period into Huronia in 1623 and 1624. This was part of Champlain's goal of native acculturation. His colonial plan, however, encompassed more than missionary zeal. According to his account of the voyages of 1615 , he wished to have French individuals and families live among native people to support and assist the missionaries. He expected the French settlers to set an example and thereby correct the conduct of the indigenous peoples so that they might learn to live in what Champlain considered a more 'civilised' manner. In a way, Champlain's scheme was too adventurous and inappropriate for the delicate situation of the small seventeenth-century French colony. The Friars had to contrive an evangelistic strategy that would satisfy his magnificent dream. ${ }^{41}$

And yet, as the fourth factor, New France had no social infrastructure for this colonial design of Champlain's. The settlement of Quebec served as a trading post, but it was merely a small village that barely sustained just over fifty settlers throughout most of the $1620 \mathrm{~s} .{ }^{42}$ It was

\footnotetext{
'Paul Huet', 'Georges le Baillif', 'Guillaume Galleran', 'Gervais Mohier', 'Irénée Piat' and 'Nicolas Viel', Dictionary of Canadian Biography Online (Library and Archives Canada, www.biographi.ca); Frédéric Gingras, 'Jean Dolbeau', 'Denis Jamet', 'Joseph le Caron', and 'Guillaume Poulain', Dictionary of Canadian Biography Online (Library and Archives Canada); and Lucien Campeau, SJ, 'Fr. Jacques de la Foyer', Biographical Dictionary for the Jesuit Missions in Acadia and New France: 1602-1654 [Biographical Dictionary, henceforth] (n.p.: William Lonc, 2001).

${ }^{41}$ George M. Wrong (ed.), The Long Journey to the Country of the Hurons (by Gabriel Sagard, Toronto: The Champlain Society, 1939), 175-76; Gabriel Sagard, Le grand voyage du pays des Hurons situé en l'Amérique vers la Mer douce, ès derniers confins de la nouvelle France, dite Canada (Paris, 1632), 238-40; and W. L. Grant, op. cit., 322-24.

${ }_{42}$ According to Champlain, Quebec started with eight settlers in 1608. Its number of residents was sixty in the winter of 1620-21, fifty in the winter 1622-23, fifty-one in 1624, fifty-five in 1626 and in the winter of 1627-28. See H.P. Biggar (ed.), The Works
} 
so fragile that it quickly capitulated to the English fleet in 1629. So few were the settlers in number that the Franciscans were not ready to promote French immigration to native villages. The missionaries were still puzzled by the different dialects derived from the Algonquian and Iroquoian tongues, the two major Amerindian language families in Canada. Consequently they were not ready to establish an effective communication with the indigenous peoples. These four factors caused the missionary strategy of the French Friars, or the pioneer missionaries to be correct, to appear culturally Eurocentric.

\section{b. The Jesuit Missions in the Saint Lawrence Valley until the 1630s}

The Jesuit missionaries up to this point were small in number. It was in 1625, during these Franciscan ventures, that three Jesuits were recruited to collaborate in the colonial missions. They were Father Énemond Massé, who had once been in Acadia, as well as Fathers Charles Lalemant and Jean de Brébeuf. Father Anne de Nouë joined them in 1626. Father Lalemant, the first superior of the mission of New France, stayed in North America for only a few years. ${ }^{43}$

Although the situation confronting the Jesuits was similar to that of the Franciscans, the Jesuits had one great advantage: They were under no obligation to follow Champlain's plan to impose French cultural mores and language upon the indigenous peoples. This was because Champlain was not involved in dispatching the Jesuits to New France. Thus, the Jesuits considered him merely a colonial leader of the French outpost, with whom they needed to co-operate only for their benefit. Back in France, the Jesuits were diplomatic and clever enough to control the higher echelons of the colonial administration of New France. Thus, the Jesuits approached Henri de Lévis, Duc de Ventador, who exercised more political power than Champlain, to make arrangements for their return to North America. In 1625, the Jesuit Father Philibert Noyrot, Ventadour's confessor, urged him to purchase the vice-regal office of New France held by his uncle Henri de Montmorency. Ventadour subsequently sent three Jesuit fathers and two coadjutor brothers

of Samuel de Champlain (6 vols., Toronto: The Champlain Society, 1922-36), vol. 2, 68 [2: 68, henceforth]; 6: 10, 87, 136, 201, \& 135-36. Cf. Edgar McInnis, Canada: A Political and Social History (1947, rev. ed., New York: Holt, Rinehart and Winston, 1959), 34.

${ }^{43}$ Campeau, 'Charles Lalemant', Biographical Dictionary, 232-34. 
to Quebec at his own expense. ${ }^{44}$ Later in 1635 , when Champlain died, the Jesuits managed to free themselves completely from his ideology of acculturation.

Moreover, external events weakened Champlain's hold on Quebec and the Jesuits. In 1627, Cardinal Richelieu began to rule the colony directly from Paris via the Company of One Hundred Associates. Although Champlain was declared Richelieu's commander, the colony stagnated because of colonial competition between England and France. In 1629, Champlain was forced to hand over Quebec to the Kirke brothers from New England. He left for France. Although Quebec was returned to France in 1632, Champlain did not return until 1633. The Jesuits rarely faced a powerful Champlain, who was no longer a hindrance to Jesuit plans.

The Jesuits in the second half of the 1620s, however, were similar to the Friars in that they too were not ready to pursue an active and extensive mission to the indigenous peoples. As such, there was no methodological contrast between the Franciscans and the Jesuits. And yet the Jesuits, at least, sought to learn Amerindian tongues, following the example of the missionaries in Japan when trying to preach to nonChristians. In 1626, Fathers Brébeuf and Nouë and the Franciscan Father D'Aillon visited the Huron country and learned the local language. Three years later, according to Father Paul le Jeune, Father Brébeuf was able to recount some Bible stories and relate theological matters to the Huron people. Also, he prepared a Huron-language catechism, which was published in 1630 and $1632 .{ }^{45}$

Even after 1632, the Jesuits were slow in developing their own evangelistic approaches. The task for the missionaries was still to learn various dialects of both Algonquian and Iroquoian languages. Father

${ }^{44}$ Trigger, The Children of Aataentsic, 402-04; and Campeau, 'Henri de Lévis', Biographical Dictionary, 266-69.

${ }^{45}$ Paul le Jeune's Relation of 1633, in Reuben Gold Thwaites et al (eds.), The Jesuit Relations and Allied Documents (73 vols., Cleveland, $\mathrm{OH}$ : Burrows Brothers, 1896-1901), vol. 5, 191-93 [Relations 5: 191-93, henceforth]; and René Latourelle, SJ, Jean de Brébeuf's Writings: A Study (trans. William Lonc, SJ \& George Topp, SJ, n.p.: William Lonc, 2001), 19-20. According to Latourelle, the catechism's title is Doctrine chrétienne du R.P. Ledesme de la Compagnie de Jésus, traduite en langage Canadois, autre que celui des Montagnais (sic), pour la conversion des habitants dudit pays (Rouen: Richard l'Allemant, 1630). It was later inserted into Samuel de Champlain, Les voyage de la Nouvelle France occidenntale, dicte Canada, et Un catéchisme ou instruction traduite du françois au langage des peuples sauvages de quelque contrée... (Paris: Louis Sylvestre, 1632). 
Le Jeune, the new superior, arrived in the colony in July 1632, and, in order to learn the Algonquian tongue, he wintered among the Innu from 1633 to 1634 . To learn the Iroquoian tongue, Fathers Jean de Brébeuf and Antoine Daniel travelled with their native companions as far as the Huron country to re-establish a mission there in 1634.

\section{c. The Continuity between the Two Religious Orders}

There was thus continuity between the Franciscan policy before 1629 and the Jesuit strategy of the 1630s. For example, the initial target groups for the Jesuits were the same as those of the Franciscans: the Innu near the French settlement and the semi-sedentary Hurons on Georgian Bay, both of whom were important trading partners for the French. Also, like the Franciscans, the Jesuits still attempted to send a limited number of select pupils to France and recruited native children for an elementary French-style school near Quebec. Above all, both parties set up strict conditions for baptism, except when baptising those faced with death, as will be discussed below.

(1) Initial Attempts at Baptism

Seventeenth-century French missionaries' attitudes to baptism were based on ideas formulated by the sixteenth-century missionaries. The priests in these two centuries firmly believed that, as a prerequisite to faith, the potential convert must be 'civilised' according to European standards. When Father Xavier justified his choice of Japan as his new missionary field, for example, he introduced it to his readers as the most civilised nation he had met thus far in the East and, as such, perfect as a potential source of converts. ${ }^{46}$ In the minds of seventeenthcentury French priests, even before they set foot on the soil of New France over a half century later, the missionary experiences in East Asia represented an evangelism that was suited to a cultured country.

Once the missionaries, whether Franciscan or Jesuit, encountered the Amerindians of New France, it was obvious that the same approach to baptism as had been adopted towards 'civilised' nations was impossible there, at least in the short term. The Amerindians were not regarded as meeting the prerequisites for acquiring the Christian faith. Faced

\footnotetext{
${ }^{46}$ Xavier to his companions living in Goa, from Kagoshima, 5 November 1549; and Xavier to his companions in Europe, from Cochin, 29 January 1552; in Costelloe, op. cit., 292-313 \& 326-43, esp. 297-98, 330, \& 334-35.
} 
with Amerindians who appeared totally uncivilised, at least from a Euro-Christian standpoint, the missionaries were confirmed in their preconception that only 'civilised' people like Europeans, and like the Japanese, were qualified for baptism. They were consequently forced to discard the sixteenth-century Iberian approach to baptism, considered to apply only to cultured nations. The Franciscan Brother Gabriel Sagard noted that conversion of the indigenous peoples would require teaching them how to lead a virtuous life, following the example of 'civilised' Christians, before the missionaries could begin to teach them theology. Evaluating people according to one's own standard of civilisation was reflected in Father Brébeuf's view of the indigenous peoples as just above the condition of beasts, so different from 'civilised' non-Christians, such as the Japanese, to whom his Jesuit predecessors had hitherto preached. Based on consultation with theologians at the Sorbonne in the late 1610s, the Récollet Franciscans had decided to baptise native candidates only after prolonged instruction and a cautious trial of faith, or else when they agreed to live with French settlers in a Euro-Christian way. ${ }^{47}$ The only exceptions were the dying, whom the Friars decided to baptise immediately in order to save souls from the flames of Hell.

In practice, however, the Friars were unable to keep to their strict baptismal policy formulated in France. When they reopened the Huron missions in 1623, for example, they baptised three indigenous people within a short period even though they spent little time in attempting to 'civilise' any of them or in persuading them to move to the French settlement. ${ }^{48}$ Because the Franciscans were excluded from the Saint Lawrence basin from 1629 onwards, their grand designs for Christian conversions remained at the level of theory.

Like the Friars, the Jesuits lowered their standards for baptism only if those concerned were in critical condition, with no hope of surviving. ${ }^{49}$ There was, however, a slight difference between the baptisms near Quebec and those in the Huron country. In the 1630s, the Jesuits,

\footnotetext{
${ }^{47}$ Chrestien le Clercq, op. cit., vol. 1, 147-48; and Trigger, Children of Aataentsic, 379.

${ }^{48}$ Wrong, The Long Journey, 175-76; Sagard, Le grand voyage, 238-40; Trigger, op. cit., 379; Jean de Brébeuf's Relations of the Hurons of 1636, in Relations, 10: 221; and Le Clercq, op. cit., 147-48 \& 257.

${ }^{49}$ Baptising only extremely sick people without reservation was already the Jesuit policy taken by Father Pierre Biard, who worked in Acadia in the early 1610s. See Biard's Relation of New France published in 1616, in Relations 4: 91-97.
} 
as guests in the Huron country, were unable to exert much influence, even when it came to baptism. The Jesuits were able to baptise dying Hurons only after requesting permission from the parents or spouses, and the Jesuits were unable to impose other baptismal conditions. In the case of little children who had even a slight chance of survival, the missionaries like Fathers Brébeuf and Nouë set no prerequisite for baptism. When more Huron people suffered epidemics towards the late 1630s, Father François-Joseph le Mercier reported that they often baptised dying babies and little children secretly without the consent of their parents. ${ }^{50}$

By contrast, in the missions to the migratory Algonquian language groups, such as the Innu and the Algonquin near the French settlements on the Saint Lawrence Valley, Father Paul le Jeune and his companions were able to set more strict conditions during the 1630s because they dealt mainly with native visitors who were often induced to settle down near Trois-Rivières or Quebec. Rather than turning them into 'civilised' people before baptising them, the Jesuits offered the parents the option of allowing the missionaries to take the children to the French settlement for Christian instruction upon recovery, as is stated in Father Le Jeune's Relations of 1633 and 1636. With ailing adults, the Jesuits in Quebec delayed baptism as long as possible because they feared that the native patients might apostatise on recovering health. In Father Le Jeune's Relation of 1636, Father Pierre Chastellain made a dying young man wait for his baptism until the eve of his death. In the same report, a dying woman had to promise Father Jacques Buteux to be faithful to Christianity if she should regain her health. ${ }^{51}$

\section{(2) Later Attempts at Baptism}

Because of more frequent interactions and easier communications between the French and the Amerindians, baptising healthy people grew possible towards the mid-1640s. In keeping with the dreams of the Franciscan predecessors, the Jesuits tried to impose even more strict prerequisites on their adherents in order to instruct the indigenous peoples in a Euro-Christian mode. ${ }^{52}$ Just as the Friars' ideology

\footnotetext{
${ }^{50}$ Le Jeune's Relation of 1634, in Relations 6: 109-13; Brébeuf's Relation of the Hurons of 1635, in Relations 8: 135-37; and Joseph le Mercier's Relation of the Hurons of 1637, in Relations 14: 7-9, 41, \& 67-69.

${ }^{51}$ Le Jeune's Relations of 1633, 1634 and 1636, in Relations 5: 227; 6: 129-39; 9: 7-17, 41, 51-53.

${ }^{52}$ Even before the Friars in the 1620s, Father Biard, who worked in Acadia in the early 1610 s, had already emphasised the necessity of thoroughly catechising native
} 
differed from their practice, Father Le Jeune's initial expectation contrasted with his later attitude towards the migratory Algonquian peoples. At first, he was optimistic about their conversions. Once Father Le Jeune found a practical opportunity for baptism, however, he persisted in demanding the abandonment of what he considered extreme paganism and in implanting in its place Christian piety, as the Jesuits in Japan had done. In 1639, Father Le Jeune described a young Algonquin catechumen who was forced to wait at least a year before being baptised. In 1642, the Jesuit fathers postponed the baptism of a young native man at the native settlement of Sillery for two years, since they doubted his constancy of faith. According to Father Barthélemy, Vimont's Relation of 1643-1644, the Jesuits postponed the baptisms of several catechumens at Sillery by telling them that they had not demonstrated a solid faith in God. ${ }^{53}$ So too, in the country of the Hurons, who were a semi-sedentary people of Eastern Woodlands, the Jesuits set high standards prior to baptising healthy indigenous people. $^{54}$

In the 1640s, the Jesuits adjusted the conditions for baptism, mostly to suit themselves. At first, the missionaries applied even stricter rules. In 1642, for example, Father Lalemant reported that the missionaries at the station of Sainte Marie, which they built in Huronia in 1639, reserved the baptism of healthy indigenous people for the festivals of Easter and Pentecost. To be baptised, candidates had to show a marked increase in faith. Following Father Lalemant's advice, the priests

people before baptising them. See his Relation of New France published in 1616, in Relations 3: 141-49.

${ }^{53}$ Le Jeune's Relation of 1639, in Relations, 16: 113-25; and Barthélemy Vimont's Relations of 1642 and 1643-44, in Relations 22: 99-101; \& 25: 117-33.

${ }_{54}$ There were four examples. First, Father Brébeuf noted in 1635 that his party withheld further instruction unless there was danger of death. Second, when a man named Chiwatenhwa, approximately thirty-five years of age, was baptised as Joseph in August 1637, he had to discard his anti-Christian customs, such as polygamy, gambling, intoxication, wearing charms and attending feasts that the missionaries regarded as diabolical. Third, the Jesuits obliged candidates to prove the stability of their faith in order to baptise them. In 1639, Aochiati, an old man at Ossossané was forced to proclaim in public to his fellow villagers that he would abandon dances and diabolical superstitions, particularly the naked dances of which he was in charge. Lastly, in 1640, the priests postponed the baptism of a woman for over a year until they finally confirmed her virtue on her deathbed. See Brébeuf's Relation of the Hurons of 1635, in Relations 8: 141-45; Le Mercier's Relation of 1638, in Relations 15: 77-85; and Jérôme Lalemant's Relation of the Hurons of 1639 and 1640, in Relations 17: 79-83 \& 95-97; 19: 195. A similar reference is also in Charles Garnier's letter to Henri de Saint-Joseph, his brother, from the country of the Hurons, 22 May 1642, in Campeau, Monumenta, 5: 239-46, esp. 243. 
postponed the baptisms of more than one hundred villagers at Ossossané. Father Paul Ragueneau implied, in his Huron report of 1646, that the priests had set up a one- or two-year probation before granting baptism in most cases. Yet, when Father Ragueneau and his party learnt to distinguish 'absurd' customs from 'criminal' ones, based upon their Euro-Christian standards in the late 1640s, they relaxed their strict baptismal policy and tried to be more tolerant towards native customs, unless they seemed harmful to the Christian faith. ${ }^{55}$ In this respect, rather than a factional disparity between the evangelising policies of two religious orders, as alleged by Trigger and his academic supporters, there was a continuity from the original Franciscan plan for baptism of the 1610 s to the revised Jesuit plan of the $1640 \mathrm{~s}^{56}$

\section{Was There a Shift of Missionary Goals?}

\section{a. School Education}

Like the Friars, the Jesuits tried to educate native children either in France or near Quebec. At the reopening of the colonial missions in 1632, Superior Le Jeune, embraced this educational ideal. In the Relation of 1633, he announced his plan to send one child, especially an Innu child, to France annually. In the same account, he advocated educating native boys and girls by establishing seminaries in Quebec. According to Father Le Jeune, the seminary was a good place for converting native children who belonged to the regions farther up the Saint Lawrence and Ottawa rivers, since the missionaries could separate the boys and girls from their parents, who, the Jesuits feared, might prevent Christian instruction. He asked the Jesuit provincial in Paris how he might acquire a seminary for girls. In the Relation of 1633-1634, Father Le Jeune implied that the Jesuits had already been inviting Huron boys to a future seminary in the French outpost. ${ }^{57}$

${ }_{55} \mathrm{~J}$. Lalemant's Relation of the Hurons of 1642 and 1643, in Relations 23: 21-23; 26 : 213-15; Paul Ragueneau's Relation of the Hurons of 1646 and 1648, in Relations 30: 115; \& 33: 145-47; and Charles Garnier to Mutius Vitelleschi, general superior, at Rome, from Sainte Marie among the Hurons, 26 May 1642, in Campeau, Monumenta, 5: 248-250.

${ }^{56}$ Cf. Trigger, The Children of Aataentsic, 468; Trigger, Natives and Newcomers, 326; Magnuson, op. cit., 19; and Blackburn, op. cit., 130-31. All these scholars persist in contrasting the unrealised dream of the Franciscans for Christianisation with the missionary practice of the Jesuits, rather than comparing the practices of the two religious orders.

${ }^{57}$ Le Jeune's Relation of 1633, in Relations 5: 145-47, 195-97; and Le Jeune to the provincial of France at Paris, from Quebec 1634, in Relations 6: 33-89, esp. 83-85. 
Based on these ideas, the priests gradually developed their education schemes. At the Jesuit residence near Quebec, they took care of Amerindian boys who had received some education in France in the $1620 \mathrm{~s}^{58}$ As early as 1633 , Father Le Jeune attempted to instruct Innu and Algonquin children back at the residence of Notre-Damedes-Anges, where the Franciscans had a seminary for a year or two in 1620. Simultaneously the Jesuits began to send native children to France to receive education. In 1637, for example, they dispatched or had the trading company deliver five Amerindians: a young Iroquois woman, three Innu girls and a little boy apparently of unknown tribal origin. In the summer of 1636, they began to bring Huron boys to the seminary, rebuilt at Notre-Dame-des-Anges, although it was, strictly speaking, no more than a rudimentary school. At the same site, by 1638, they also started a seminary for Algonquin and Innu boys. ${ }^{59}$

In all this, the French missionaries in the mid-1630s were different from those in the 1610s or 1620s in their objectives, or their responsibility and capability. In terms of responsibility, the Jesuits had no obligation to pursue a complete French-style education. Champlain, their collaborator, who, while commander of New France, had held unrealistic ideals, such as the implantation of the French culture and language, was no longer alive. As Father Le Jeune stated in his Relation of 1636, the missionaries' success depended generally on the development of the French settlement, and not specifically on instilling a Euro-Christian mode of life in the indigenous peoples. ${ }^{60}$ References to the dispatch of Amerindian pupils to France in The Jesuit Relations declined towards the late 1640s. As with the Jesuit education in Japan, the education of children was rooted in the principles stated in the Constitutions and Formulae of the Institute of the Society of Jesus, which controlled the religious conduct of the Jesuits.

${ }^{58}$ E.g. Louis Amantacha, a Huron, and Pierre-Antoine Pastedechouan, an Innu. See Le Jeune's letter to the provincial of France at Paris, from Quebec, 1634, in Relations 6: 33-89, esp. 85-87.

${ }^{59}$ Le Jeune's Relations of 1633,1633-34,1635, 1636, 1637, 1638 and 1639, in Relations 5: 227-31; 6: 85-89, 101, note 9; 7: 263-65, 287-89; 9: 103-05, 293-95; 11: 93-99; 14: 127, 257; \& 16: 169; Le Jeune's letter to Mutius Vitelleschi, general superior, at Rome, from Trois-Rivières, 23 August 1637, in Lucien Campeau (ed.), Monumenta Novae Franciae (Roma: Monumenta Historica Soc. Iesu; \& Montréal: Bellarmin; or Québec: Les Presses de l'Université Laval, 1967-2003), vol. 3 (1987), 508-10 [Campeau, Monumenta, 3: 508-10, henceforth], esp. 509.

${ }^{60}$ Le Jeune's Relation of 1636, in Relations 9: 97. 
As for capability, unlike the pioneer Franciscan priests two decades before, the Jesuits were no longer a tiny group of inexperienced missionaries. The Friars tutored a limited number of native children in French because it was the only language that they knew, apart from Latin or other European languages. They were not deliberately avoiding native tongues; they simply had never learnt them. Unlike these early French missionaries, who were ill prepared to instruct in any Amerindian language, some Jesuits had learnt enough for instructing boys in either the Innu or the Huron languages.

This fundamental difference of responsibility and capability was due more to the change in evangelistic environment than to the difference of religious orders. The two methods of education, the Franciscan and the Jesuit, were carried out in two different contexts; therefore, it makes little sense to attribute the differences in educational approaches to the institutional policies of these two religious orders. Even so, it may be appropriate to compare the pioneer priests with the later missionary participants in terms of methodological development. ${ }^{61}$

The Jesuit priests designed their education in the most appropriate way to suit their specific evangelistic ends. The seminary at NotreDame-des-Anges was basically a boarding school that isolated its native pupils from the French settlement, just as the Friars had previously done. The pupils followed a daily routine that included prayers, Mass, reading, writing, catechisms and the examination of consciences.

Although the Jesuit teachers pragmatically tried to bring up native boys as assistants, as had the Friars, they had more flexible options than their Franciscan predecessors in Quebec. For example, their education was conducted in two languages. The native boys were normally taught in their own Huron or Innu language, but they learnt some French as part of the curriculum. ${ }^{62}$ According to the Relation of 1639, at the Sunday school for learning the catechism, which was also open to local French boys, the Jesuits began to use French boys as models in order to speed up the learning process for Amerindian boarders. The Superior Le Jeune explained that the Jesuit teachers expected pedagogical benefits from instructing two ethnic groups together.

${ }^{61}$ Cf. Trigger, The Children of Aataentsic, 376-81 \& 467-69; Trigger, Natives and Newcomers, 200-02; J. Grant, op. cit., 38 \& 46; Charles Principe, op. cit., 317; Magnuson, op. cit., 19-20; Anya Mali, op. cit., 67-92; and Carole Blackburn, op. cit., 130-31.

${ }^{62}$ Cf. Magnuson, op. cit., 48-49. Magnuson infers that the independent native class soon ceased and merged with a French class. 
Furthermore, this education was not the traditional seminary education, which was based on Latin. Despite the French appellation 'séminaire', the Jesuits seem to have decided not to teach Latin in the native classroom, perhaps because they considered the pupils too immature to learn the Latin language. ${ }^{63}$

Like the Japanese precedents, the native seminaries in New France were based on models found at the Society's schools in Europe though the Jesuits had to adapt those models to the circumstances encountered in the missions. Superior Le Jeune began with instruction in reading and writing, somewhat akin to the example of the Iberian missionaries in Japan, who had interpreted the Constitutions of the Society in their own way. Like the Society's Constitutions, the Ratio Studiorum of 1599, set forth the Society's regulations intended mainly for the secondary schools in Europe. This rulebook shows that elementary grades were excluded from Jesuit tutelage. ${ }^{64}$ Despite this restriction, the French Jesuits in New France had little choice but to begin with the very basic instruction because the oral Amerindian tradition lacked both schools and texts. As in Japan, the main languages used for instruction in New France were the local tongues. The difference was that the Japanese seminaries taught Latin, as stipulated later in the Ratio Studiorum, whereas the Amerindian seminaries did not. Whether or not Father Le Jeune, who read the Iberian reports on Japan, followed the Iberian convention that was adjusted for the Japanese, he seems to have adopted what was necessary for educating Amerindians, based on Japanese precedents. The seminary designed by Father Le Jeune was a hybrid of two types of Japanese schools: early elementary schools using a non-European language and later seminaries for their boarding style.

By the early 1640s, however, the Jesuits abandoned the seminary for Huron boys at Notre-Dame-des-Anges, as well as the seminaries for Algonquin and Innu boys at the same site. In 1639, Father Jérôme Lalemant, who was in charge of the Huron mission, pointed to the inefficiency of converting the native nations through the instruction of

${ }^{63}$ Le Jeune's Relations of 1633, 1637 and 1639, in Relations 5: 195-97; 12: 63-69; \& 16: 179-81. James Axtell, however, asserts that the missionary teachers introduced religious instruction in Latin. Cf. Axtell, op. cit., 56-57.

${ }_{64}$ Allan P. Farrell, SJ (trans.), The Jesuit Ratio Studiorum of 1599 (Washington, D.C.: Conference of Major Superiors of Jesuits, 1970), the rules of the provincial, article 21, number 1 . 
children, and proposed that the seminaries should serve as the place for the children of Christian neophytes and adult catechumens. In the report of 1642-1643, Father Vimont, Father Le Jeune's successor as superior of New France, stated that the Jesuits had closed the seminary for Huron boys because it had not born fruit among their people back in the Huron country. ${ }^{65}$

Nevertheless, when Father Lalemant's proposal for a revision is examined, it becomes clear that the Jesuit missionaries must have been fully aware that their elementary education would produce a transformation in Amerindian society only after years of effort. Father Vimont's explanation sounds like an excuse for his inability to follow the educational guidelines of the Society, as expressed in its Formulae and Constitutions. He may have implied that a native seminary was not worth the trouble, given its heavy burden on human and financial resources as well as its lack of success.

There were several reasons for the termination of the seminaries. Roger Magnuson lists three reasons: a lack of pupils due to the reluctance of parents to entrust their sons to the Jesuits far away from Huronia; the inability of some pupils to adjust to the boarding school; and the heavy cost of maintaining them. ${ }^{66}$

There are, however, more important reasons, beyond those given by Magnuson. A comparison with the Jesuit schools in Japan reveals four fundamental conditions that the native seminaries of New France lacked to ensure their survival. First, the French Jesuits failed to establish schools that might serve native society, even though Jesuit education in principle was supposed to be a method of improving autochthonous society. While the Japanese schools were established as existing segments for Japanese society and served to make the Japanese pupils more pious, the native schools were located far from the native country and outside the French outpost. Although the non-Christian subjects taught at the Japanese schools were designed to promote literacy, the schools for Amerindians taught no useful secular subjects, but only theology and prayers that were alien to the Amerindian life in the wilderness.

${ }^{65}$ J. Lalemant's Relation of the Hurons of 1639, in Relations 16: 251-53; and Vimont's Relation of 1642-1643, in Relations 24: 103.

${ }^{66}$ Magnuson, op. cit., 50. 
Second, the French missionaries failed to convert native parents, who would have encouraged their children not only to convert but also to remain good Christians. While the Christian schools in Japan were for the children of neophytes, those near Quebec were for the boys of non-Christians, whom the missionaries had not yet converted to the faith. In other words, the French Jesuits tried to instruct the native boys whose home society was not Christian.

Third, unlike the Japanese, the Amerindians did not assist Jesuit schooling even though boarding schools usually required great financial and human resources. On the one hand, the Japanese schools, including the properties on which they were built, were sponsored not only by the Iberian merchants but even more so by their Japanese seigniorial patrons and a local congregation. On the other hand, the seminaries near Quebec were solely supported by the French patrons of the Society of Jesus.

Fourth, to the Amerindian people, education itself reinforced cultural changes, though the Jesuits were only vaguely aware of this. The Jesuits' attempt to convey French standards and thought to indigenous boys was carried out by removing them completely from their parents. The seminarians were expected to return home only after some years of education. Although the Iberian Jesuits in Japan had only to replace the Buddhist schools with those of their own Christian schools, the French missionaries began the native seminaries from nothing. In other words, the indigenous people of New France had never experienced formal education before the arrival of the French missionaries. These four factors explain the difficulties of maintaining sufficient numbers of pupils in classes and of managing the seminaries in a way that justified the investment of resources.

\section{b. Approaching Adults}

Because of the failure of Jesuit schooling for boys, historians like Axtell, Trigger and like-minded scholars consider that there was a shift of emphasis on the age groups for evangelisation. ${ }^{67}$ They believe that the missionaries originally favoured children over adults in the proselytising process, but that later, by 1640 , they replaced this original policy by

${ }^{67}$ E.g. Trigger, The Children of Aataentsic, 557-58; Trigger, Natives and Newcomers, 252; Axtell, op. cit., 57-58; and Magnuson, op. cit., 34-35. 
approaching prominent men in society who, the Jesuits hoped, would create a chain reaction of conversions.

The grounds for this interpretation lie mainly in the following incidents. According to Father Le Jeune, in his Relation of 1639, the Jesuits learnt from an elderly Huron visitor to Quebec that the missionaries were mistaken in preferring children to grown men for giving Christian instruction, because Huron society did not accept young people's opinions. In the Huron Relation of 1639, Father Lalemant, who had arrived in the colony the previous year, criticised the instructional emphasis on children of non-Christian parents as an ineffective method. Instead, he proposed converting adult men. In the early 1640s, the Jesuits began the experiment of instructing Huron traders who wintered near Quebec. ${ }^{68}$

For a century, missionaries had separated education from politics. The Jesuits throughout the world had been developing a number of means for converting non-Christians. The education of boys was one method, and the diplomatic approach to win over prominent men in the hope of inducing a religious chain reaction was another. The Jesuits knew that the education of boys was an entirely separate activity from their attempts to convert prominent leaders. Discussing these two different methods as one single evolutionary lineage obscures the composite methods that the Jesuits had gradually devised.

For evangelising the indigenous peoples, the French Jesuits used two main auxiliary approaches: philanthropy and political diplomacy, both of which their Iberian predecessors in Japan had devised over a half century before. Philanthropy, on the one hand, included education and medical help, and will be discussed later, while political diplomacy, which involved approaching prominent individuals in a foreign community, was practised, beginning in the mid-sixteenth century, in India and Japan, well before Father Lalemant's methodological proposal in 1639, which Trigger, Axtell and other academics commonly cite as evidence.

\section{(1) Hierarchical and Political Approach}

In North America also, prior to 1639, the French Jesuits adopted a political strategy for converting the indigenous peoples to Christianity at the outset of their missionary activity. When Father Pierre Biard

${ }^{68}$ Le Jeune's Relation of 1639, in Relations 16: 169-173; J. Lalemant's Relation of the Hurons of 1639, in Relations 16: 251-53; 17: 33; and Vimont's Relation of 1642-43, in Relations 24: 103-17. 
analysed the Mi'kmaq government system in Acadia in the early 1610s, for example, he focussed his attention upon two kinds of offices, the chieftain and the head of shamans, whom he apparently considered to be the key figures for missionary diplomacy. When Father Jacques Buteux began his work at Trois-Rivières in 1634, he approached an Innu chief, who, Father Buteux and Father Le Jeune hoped, would lead his community to settle down near this new French outpost. ${ }^{69}$

There were more examples that suggest that Japan was the model. In 1637, Father Le Jeune attempted to induce an Innu group to settle at Trois-Rivières. He approached and instructed Makheabichtichiou, a future chief of the Innu-Algonquin band at Trois-Rivières. ${ }^{70}$ At that time, Makheabichtichiou was ill. When he recovered under Jesuit care, he helped with missionary work. Makheabichtichiou expounded elementary Christian doctrine to his community on one occasion, and accompanied his Innu chief on another occasion. This chief asked Father Le Jeune for his help in obtaining permission from Governor Charles Huault de Montmagny and the French settlers to settle near this French outpost. ${ }^{71}$

The missionaries also made every effort to convert Huron headmen. When Tsiouendaentaha, a prominent chief in his fifties, became the first Huron convert baptised as a healthy person in 1637, Father Le Mercier never failed to mention this baptism and the influence it exerted upon the villagers. Subsequently these villagers began to ask for baptism while in good health. Another example was Chiwatenhwa, whom Father Le Mercier described as approximately thirty-five years of age. Although he was offered baptism only when near death in August 1637, he was such an influential person that he helped the missionaries to persuade a chief of Ossossané to exhort his villagers to receive religious instruction. Consequently the Jesuits were successful in approaching another chief of Ossossané, whose name Father Le Mercier did not mention, in the hope that he would persuade his people to convert to Christianity. ${ }^{72}$

${ }^{69}$ Pierre Biard's Relation of 1616, in Relations 3: 87-125; and Le Jeune's Relation of 1635, in Relations 8: 55-57.

${ }^{70}$ Father Le Jeune described Makheabichtichiou as the chief of a Trois-Rivières band of the Innu and the Algonquin as well as his eventual baptism in his Relation of 1638. See Relations 14: 131-33 \& 145.

${ }^{71}$ Le Jeune's Relation of 1637, in Relations 11: 149-65; 12: 151, 161-63, \& 173.

${ }^{72}$ Le Mercier's Relations of the Hurons of 1637 and 1638, in Relations 14: 77-99; 15: $77,117-19$ \& 125 . 
Father Lalemant's emphasis on conversion of adult men in 1639 was therefore a reconfirmation of his overall methodology, which, instead of being a plan of his own invention to shift the emphasis from children to adults, seems to resemble the policy followed in Japan in the sixteenth century. Although his praise of Father Xavier may be insufficient to gauge his knowledge of the Jesuit missions to Japan, it must be pointed out that he concluded the chapter of this methodological proposal with a reference to Father Xavier, which suggests that he was well versed in the multifaceted approach that Father Xavier and his successors designed for converting non-Christians in Japan. ${ }^{73}$ No matter how much Father Lalemant was aware of the grand missions of his Iberian predecessors, by understanding that connection, one is better able to interpret his proposal. When Father Lalemant arrived in New France in 1638, he seems to have recognised a fundamental flaw in the missionary enterprise, that except for the establishment of seminaries, there had been little progress. And even the seminaries were scarcely successful. They were instructing the boys of non-Christian parents. To make matters worse, the instruction and discipline were alien to Amerindian customs. At the same time, the missionaries were unsuccessful in converting adults in the Huron country although they should have done it before undertaking the education of children to ensure that the parents did not hinder the children's Christian practice upon their return home after the completion of their education. This reversal of the usual practice of first finding an influential native patron, then dealing with children afterward, almost guaranteed failure. It was natural for Father Lalemant to criticise Father Le Jeune's educational scheme and to propose a more conventional evangelisation methodology similar to the one that had been adopted in Japan.

\section{(2) Collaborative Philanthropy}

Another method for converting indigenous peoples to Christianity was the use of social philanthropy, which included education, alms giving and medical help. As late as the 1640s, rudimentary education was a main part of Jesuit philanthropy in Canada. The missionaries terminated the boarding school for native boys, but soon achieved some success in their attempt at two other forms of education that they had planned since the mid-1630s. One form was general schooling at the

\footnotetext{
${ }^{73}$ J. Lalemant's Relation of the Hurons of 1639, in Relations 17: 55.
} 
missionary residences in Huronia for children, neophytes and catechumens. It began as a Sunday school for children, under the leadership of Father Brébeuf in 1636. By 1639, when Father Lalemant made his report on the Huron missions, it had developed into an instructional site. Because of this effort to teach children and adults in Huronia, the demise of the seminary near Quebec does not necessarily indicate that the Jesuits entirely abandoned the education of Huron children. ${ }^{74}$

The other form was a seasonal education for young Huron traders at the French settlements. In the autumn of $1642,{ }^{75}$ when Father Brébeuf had already returned to Quebec and was available as an interpreter, the Jesuits began to instruct six or more young Huron men, who visited Quebec for trading and wintered near the French outpost apparently to hunt for fur animals with Algonquin settlers at Sillery and to engage in war against the Iroquois. Through this experience with the Huron traders, Father Vimont, who had succeeded Father Le Jeune as superior in Quebec, reported, in his Relation of 1642-1643, on the idea of opening a 'seminary' for young Huron men, by which he probably meant some form of instruction without actually constructing a school building. Subsequently Father Brébeuf and his companions provided seasonal instruction for another six Huron men at Trois-Rivières from the early winter of 1643 until the spring of $1644 .{ }^{76}$

This attempt to instruct young Hurons, however, does not represent a shift in educational objectives from children to young men, since it neither began as an alternative for the seminary institution for boys nor shared the same civilising principle. The missionaries had already begun a similar attempt to offer Christian instruction to Huron traders near the French settlements as early as 1637, almost simultaneously with the founding of the Huron seminary. And yet before the early 1640s, the Jesuits were completely unsuccessful in persuading the traders to dwell, even seasonally, near the outposts. ${ }^{77}$ Moreover, the young men were not forced to attend but came on their own initia-

${ }^{74}$ Brébeuf's Relation of 1636, in Relations 10: 19-25; and J. Lalemant's Relation of the Hurons of 1639, in Relations 16: 248; Le Jeune's letter to Mutius Vitelleschi, general superior, at Rome, from Troi-Rivières, 8 August 1636, in Campeau, Monumenta, 3 : 155-57, esp. 157.

75 This year might be the autumn of 1641. Because Vimont's Relation of 1642-1643 is undated, his reference to 'l'an passé' can mean either 1641 or 1642. See Relations 24: 103-105.

${ }^{76}$ Vimont's Relations of 1642-1643 and 1643-1644, in Relations 24: 103-121; \& 26: $19-29$.

77 Le Jeune's Relation of 1637, in Relations 12: 255-59. 
tive primarily to trade at the French outposts and, unlike the former young seminarians who boarded inside a Jesuit monastery, they were not segregated from other Amerindians or from French settlers.

The indirect attempts by the Jesuits to educate girls through the collaboration of French nuns also contradict the conventional wisdom that the Jesuits shifted their instructional efforts from native children to adult men. When the Jesuits failed to maintain the seminaries for boys, they invited two female religious organisations from France in 1639: the Ursuline nuns and the Hospital nuns. The Ursuline education for girls was part of Father Le Jeune's initial missionary scheme, proposed as early as 1633. Upon arrival in Quebec, the Ursulines were stationed at the nearby native settlement of Sillery. By 1640, they had opened an elementary school, which Father Le Jeune called 'séminaire', for eighteen native girls, including at least six orphans. ${ }^{78}$ This school served French and native girls, both as day students and as boarders. The Jesuit missionaries co-operated in this female education. In his Relation of 1639, Father Le Jeune wrote that he had recruited the daughter of a dying native woman at Sillery for the Ursuline school. Fathers Jacques Buteux and Claude Pijart, the second of whom had formerly been in charge of the Jesuit seminary, participated in the instruction of indigenous girls. ${ }^{79}$

The Hospital nuns, as well, contributed to the education of girls and boys. Upon their arrival in Quebec, these native youngsters were lodged temporarily in a house of the Company of One Hundred Associates, near Fort Saint-Louis in Quebec. In June 1640, the nuns moved to Sillery and, in December, entered their convent building that was completed by the following spring. In his Relation of 1642-1643, Father Vimont noted that the Hospital nuns instructed native girls and boys through prayers and catechisms at their house, which served as a medical clinic. ${ }^{80}$

${ }^{78}$ Le Jeune's passages in his Relation of 1639 are clear about the orphanage of six girls, but not clear enough about the orphanage of the eighteen seminarians. Because his Relation of 1640-1641 refers to a Huron girl whose mother lived in her native country, not all the initial seminarians seem to have been orphans. See Relations 16: 09; \& 19: 137-39.

${ }_{79}$ Le Jeune's Relations of 1633, 1639 and 1640, in Relations 5: 145-47; 16: 09-21, 67-69; 19: 37-39, 45-49; and Vimont's Relations of 1642-1643 and 1643-1644, in Relations 23: 315; \& 25: 225.

${ }^{80}$ Relations 16: 23, note 8; Le Jeune's Relation of 1640-1641, in Relations 20: 237; and Vimont's Relation of 1642-1643, in Relations 23: 311-13. 
Because of the many and varied needs of the indigenous people who were in contact with the French, the nuns had to devote themselves to other kinds of charity in collaboration with the Jesuits. When the Hospital nuns began their medical service in 1639, their temporary clinic in Quebec was soon full of Amerindian patients in serious condition. The nuns abandoned their first house, which was owned by the Company of One Hundred Associates, and moved to Sillery in 1640. By 1643, they resumed their medical service for French and Amerindian residents at the Hôtel-Dieu de Québec, their own building whose construction was commenced in 1638 and completed in 1644. In Sillery, their convent building, the House of Mercy, served not only as a medical clinic but also as an asylum for needy residents, including those abandoned by their own people. Also, the Ursuline convent building extended its educational service by functioning not only as an orphanage, but also as a source of alms for both men and women of all ages. Then in 1642, the Innu residents at Sillery co-operated with the missionaries and nuns in offering charity to a larger number of native migrants. In the late 1640s, the Ursuline convent served as a shelter for those destitute refugees who had escaped from the Iroquois nations. When bands of Huron refugees were led by the missionaries to Quebec in 1650, both the Hospitallers and the Ursulines provided them with all possible help. In these cases, charity was an inducement to conversion. ${ }^{81}$

Such philanthropy, however, was certainly not a stopgap solution adopted quickly as a replacement for the Jesuit education of Amerindian boys. The idea of extending charity to native people was mentioned in the Jesuit correspondence long before the termination of the seminaries. Just as with his request in 1633 for the founding of education for Amerindian girls, Father Le Jeune stated as early as 1634 that a hospital was necessary for indigenous peoples, once he had learnt of the outbreak of disease among the native people at Trois-Rivières in 1633. He repeated this proposal in 1636. The establishment of hospitals run by other religious orders was particularly important for the Jesuits because the Society of Jesus prevented its members from becoming

${ }^{81}$ Le Jeune's Relations of 1639 and 1640-1641, in Relations 16: 217-19; 20: 235-41; Vimont's Relation of 1642-1643, in Relations 23: 311-15; 24: 67-69, 111-15; 159-61; Lalemat's Relation of 1647-1648, in Relations 32: 213-15, 233; Paul Ragueneau's Relation of 1649-1650, in Relations 35: 209; and François-Joseph Bressani’s Relation of 1641-1642, in Campeau, Monumenta, 5: 347. 
directly involved in medical treatment. To introduce a hospitalthe Hôtel-Dieu de Québec in 1644, for example-the Jesuits' friends in France made an effort to secure the sponsorship of Marie-Madeleine de Vignerot in Paris, the Duchesse d'Aiguillon, who was a niece of Cardinal Richelieu. ${ }^{82}$

Strictly speaking, however, the charity near Quebec was not typical missionary philanthropy in a foreign land, for the religious organisations dealt only with their native guests in the French settlements without expanding their service beyond the outposts. It was akin to the expansion of the French settlements through missionary diplomacy with Amerindian neighbours. Such work, similar to the sixteenth-century Jesuit philanthropy among non-Christians in countries such as Japan, began only at the missionary station of Sainte Marie, in the country of the Hurons. Under the leadership of Father Jérôme Lalemant, the missionaries and their lay assistants began to build this fortified mission station in the territory of the Ataronchronon, an eastern division of the Attignawantan Hurons, in $1639 .{ }^{83}$

From an international perspective, the residence of Sainte Marie was more an emulation of Jesuit charity houses in Japan than Father Lalemant's own 'innovation', which is how Trigger describes it. ${ }^{84}$ Father Lalemant's scheme of missionary charity, based at the residence of Sainte Marie, was similar to the philanthropy under the leadership of Father Cosme de Torres, one of the pioneer missionaries who accompanied Father Xavier to Japan. Both Jesuits began their philanthropy in a foreign land, away from the trading establishments. Both chose as the sites for their missionary centres regions with a history of goodwill towards Europeans, where they could secure political patronage. Through philanthropy, both Father Torres and Father Lalemant attempted to convert indigenous peoples without segregating neophytes or catechumens from their home communities. Because of these common backgrounds, the station of Sainte Marie functioned, like

${ }^{82}$ Le Jeune's Relations of 1634, 1636, 1638 and 1639, in Relations 6: 61-63, 143; 8: 233-35, 99-101; 14: 125-27; \& 16: 217-19.

${ }^{83}$ J. Lalemant's Relation of the Hurons of 1640, in Relations 19: 167; and J. Lalemant to Mutius Vitelleschi, general superior, at Rome, from Ossossdané, 25 May 1639, in Campeau, Monumenta, 4: 231-33. For the relationship between the Ataronchronon and the Attignawantan, see Trigger, Natives and Newcomers, 252-53.

${ }^{84}$ Trigger, op. cit., 252-53. 


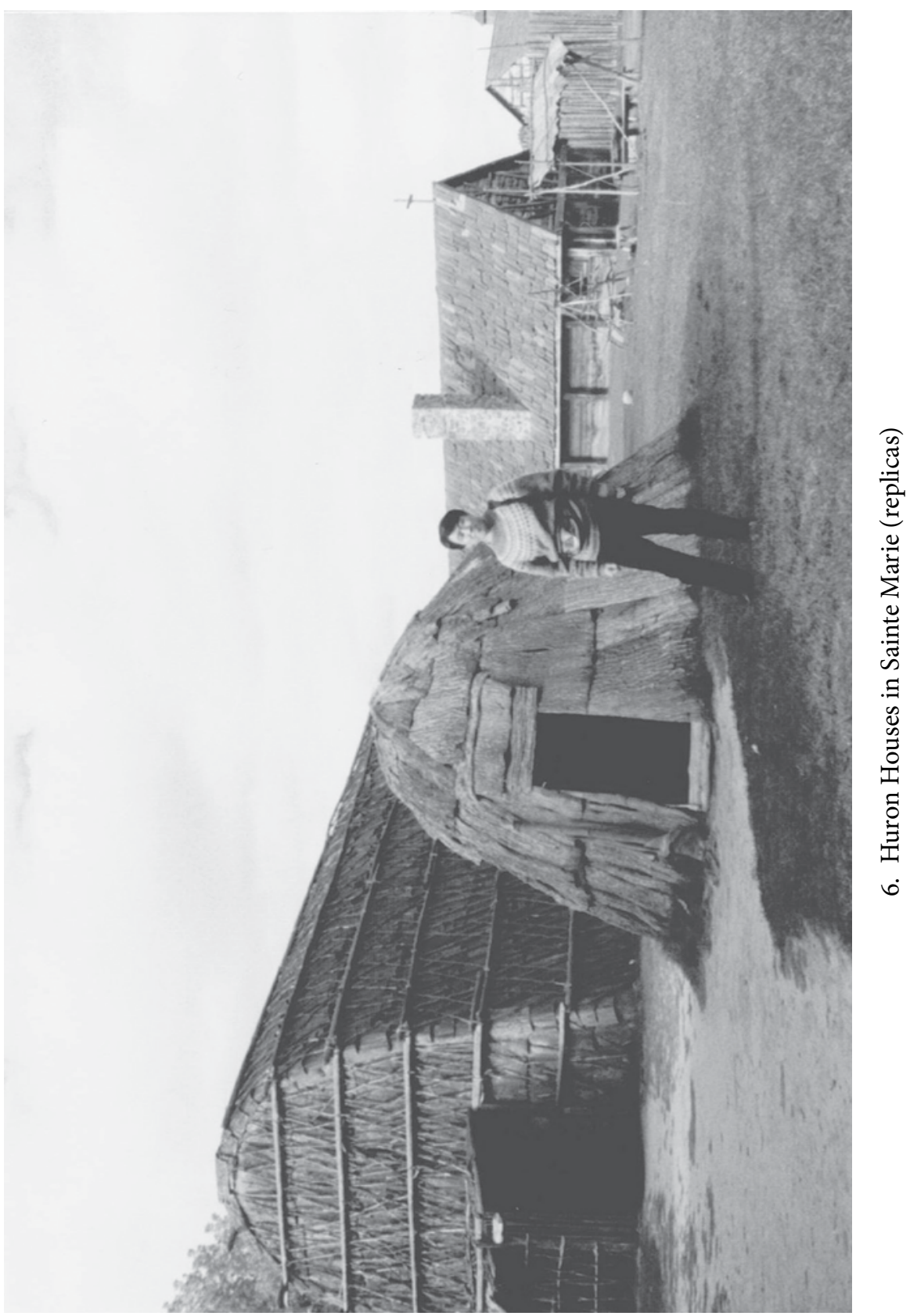




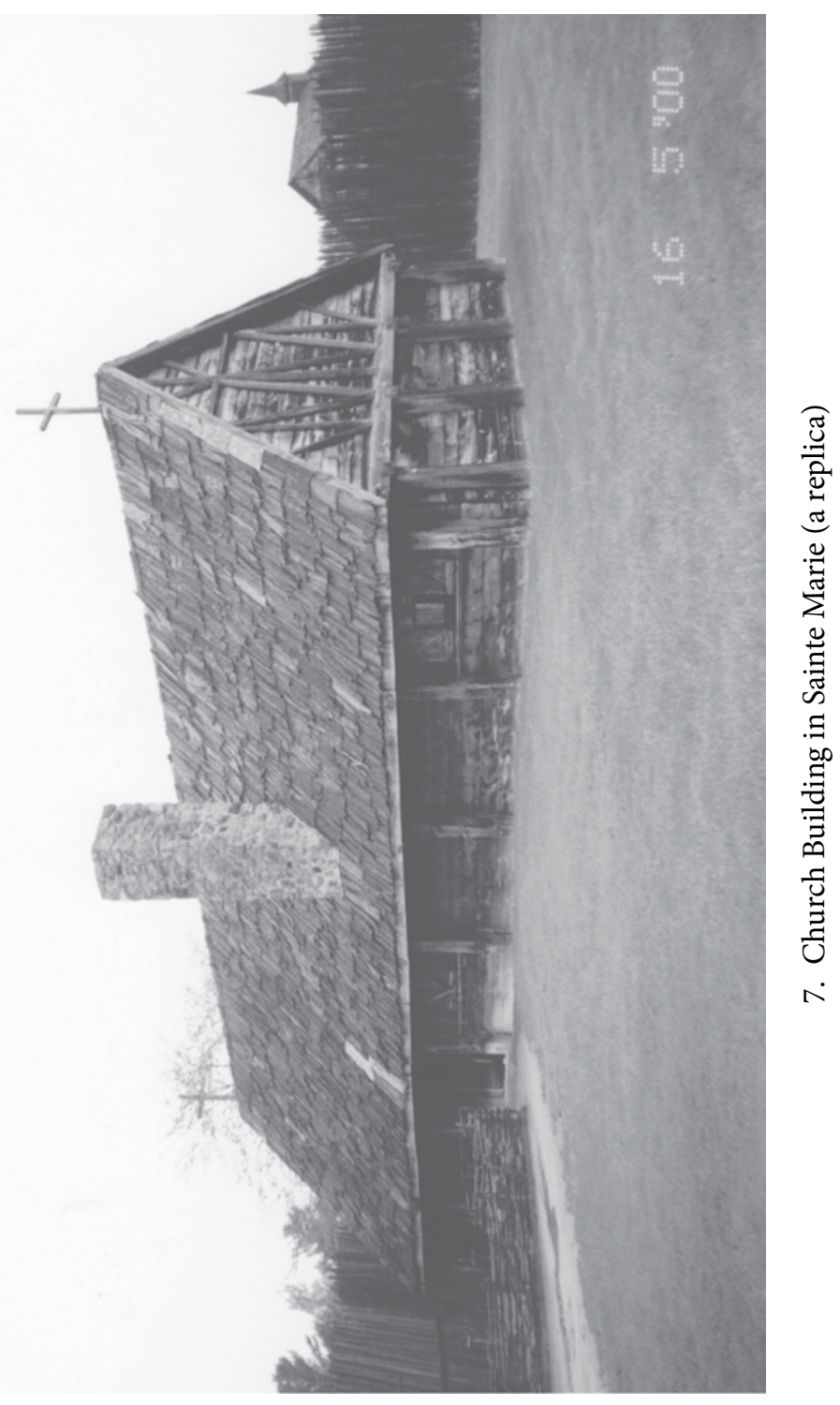




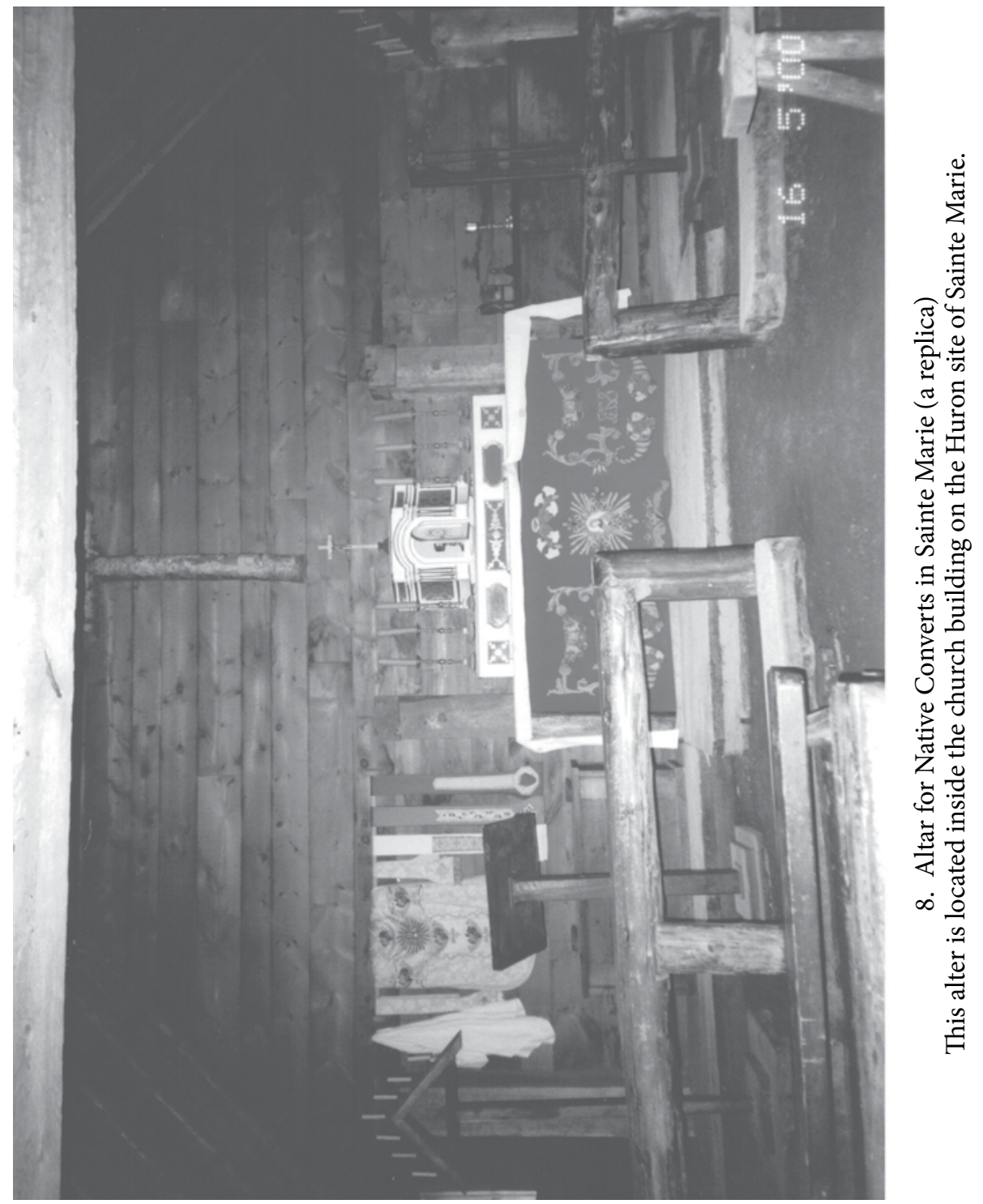


several of the Jesuit residences in Japan, as a medical clinic, a refuge and a hospice for Huron visitors. ${ }^{85}$

\section{A New Paradigm for the Missionary Strategy IN NeW France}

This discussion leads to two conclusions. First, when considering the Japanese and Canadian missionary cases, one should abolish those simplistic labels like cultural absolutism and cultural relativism that recent historians in the Canadian field have used. Despite popular ideas about the methodological difference between the Franciscans and the Jesuits in the Canadian historiography, there was little factional difference between the Franciscans and the Jesuits in terms of missionary policies. Any plausible difference was, strictly speaking, simply the result of continual evolution of missionary strategies throughout the first half of the seventeenth century. The variation of missionary policy was caused by the shifting responsibility and experience of priests who adjusted themselves to changing evangelistic environments. Distinguishing the two missionary bodies in stereotypical terms of cultural absolutism and cultural relativism merely serves to confuse the true characteristics of these religious orders by ignoring the evangelistic situations peculiar to each stage of missionary development.

Second, basic methodological similarities between the Iberian missions and the French missions demonstrate that the Society of Jesus, since the pioneer years of Father Xavier, had already evolved multifaceted strategies internationally when its French group began evangelistic activity in New France. The Jesuit approach cannot be described simply as a shift from converting children to evangelising adults, as influential scholars in the Canadian historiography have claimed for more than three decades. In Japan and New France as well, the missionaries worked with a variety of approaches, with an emphasis on two basic lines: political diplomacy and philanthropy. The philanthropy consisted of works of charity, medical help and elementary education. The early Jesuit education could well be regarded as a third independent line of approach if one considers the Jesuit boarding schools to have been seminaries rather than elementary schools. Here, one should recall that they never functioned as institutions

${ }^{85}$ J. Lalemant's Relation of the Hurons of 1643, in Relations 26: 201-03; and Ragueneau's Relation of the Hurons of 1647-1648, in Relations 33: 77, 99-101. 
for bringing up future native priests in New France. Failure to distinguish these two or three lines of methodological evolution in the French missions blinds historians to the evolution of the multifaceted methods that Christian missions beyond Europe adopted from the mid-sixteenth century to the mid-seventeenth century because the missionary policy in Canada drew on previous experience and evolved continuously. 


\section{ORGANISING A MISSION FOR A CHRISTIAN COMMUNITY: MISSIONARY RÉDUCTIONS RECONSIDERED}

In order to convert Amerindians who lived and hunted in lands far away from French settlements in North America, the Jesuit missionaries sought to gather these Amerindians into native Christian reserves near the French colonial settlements along the Saint Lawrence River. The missionaries encouraged the Algonquian and Iroquoian peoples to settle down in these missionary settlements to live as neophytes. Father Paul Le Jeune called such Christian settlements 'réductions' following the example of Jesuit predecessors in South America, who labelled the Paraguayan reserves 'reducciónes'.

Two interrelated issues arise from this evangelistic approach to settling Amerindians in réductions. The first issue is whether the idea for the Paraguayan reducciónes was created without precedent before it was introduced into North America. Or were the reducciónes based on models found elsewhere? In other words, is it possible to trace the prototypes-if not the origin ${ }^{1}$ - for the Canadian réductions beyond Paraguay? The second issue is to what extent the New France réductions emulated the Paraguayan models. Alternatively did the 'réduction' scheme of New France originate only in a Paraguayan model and in no other missionary models?

To seek answers to these two issues, a reconsideration of the Jesuit réductions should go as far back as the pioneer Christian communities in sixteenth-century Japan, beyond the Paraguayan models that began in the early seventeenth century. This consideration should also search for the missionary achievements beyond Europe. The initial step for such analysis is to establish the interconnection between the Paraguayan and Japanese missions. Then, the native Christian communities in New France can be discussed in the light of earlier experiences

1 This 'prototype' means the prototypical establishment of a Christian community in formerly non-Christian regions. Because a simplistic search for the 'origin' of reductions may reach as far back as the ancient centuries, the search will complicate the current argument or even obscure the vital aspect of analysis. 
in both Paraguay and Japan. Using this approach, features common to the two types of Amerindian missionary communities in New France and Paraguay may be seen to have their prototypes in the earlier Jesuit experiments in Japan. Other features that seem to have been unique to New France may, in fact, have been based directly on the prototypical experience in Japan.

\section{A. The Prototypes for Amerindian Réductions}

\section{Existing Interpretation of the Laurentian Réductions}

Father Le Jeune, the Superior of New France during the 1630s, was the first missionary to mention the Paraguayan mission. He did so in order to justify his plan for establishing a settlement for nomadic Amerindians. When the Jesuits renewed the mission in New France in 1632, the superior was already familiar with the Jesuit experience in colonial Paraguay, ${ }^{2}$ an enormous region that encompassed today's Paraguay as well as eastern Bolivia, Argentina, southwest Brazil, Uruguay and Chile. In the Relation of 1637, for example, he referred to the Paraguayan experiment as a model for native settlements in New France. Later he used the Latin term 'reduximus' in 1638 and the French term 'réduction' in 1639 to refer to the first native mission of Sillery, which the Jesuits arranged for an Innu group. ${ }^{3}$

These Jesuit references to Paraguay influenced later interpretations of the Amerindian missionary settlements. In the historiography of the Jesuit missions in New France, a wide range of historians from the nineteenth to the twenty-first centuries maintain that the system of Canadian réductions was an emulation of the Jesuit reducciónes in colonial Paraguay. Those who so argue include the Ursuline Mother Sainte-Croix, Gabriel Gravier and Joseph Edmond Roy, in the nineteenth and early twentieth centuries. More recently Lucien Campeau,

${ }^{2}$ Henceforth, 'Paraguay' means 'colonial Paraguay' unless specified otherwise.

${ }^{3}$ Paul le Jeune's Relation of 1639, in Reuben Gold Thwaites et al (eds.), The Jesuit Relations and Allied Documents (73 vols., Cleveland, OH: Burrows Brothers, 1896-1901), vol. 5, 31-33 [Relations 5: 31-33, henceforth]; Relations 12: 219-23; 14: 205-07; \& 16: 135-141; and Le Jeune to Mutius Vitelleschi, general superior, at Rome, from Trois Rivières, 1st August 1638, in Lucien Campeau (ed.), Monumenta Novae Franciae (Roma: Monumenta Historica Soc. Iesu; \& Montréal: Les Éditions Bellarmin; or Québec: Les Presses de l'Université Laval, 1967-2003), vol. 4 (1989), 54-57 [Campeau, Monumenta, 4: 54-55, henceforth], esp. 55. 
John W. Grant, Bruce G. Trigger, Marc Jetten, Carole Blackburn and Jean-Jacques Simard, among many others, expressed a consensus that the French Jesuits developed a réduction scheme based directly upon the Paraguayan system of Christian settlements from the early seventeenth century. ${ }^{4}$

There have been a few attempts at modifying this popular perspective on the native reserves on the Saint Lawrence. One alternative approach is to seek another prototype. According to Cornelius J. Jaenen, the Canadian réductions were modelled upon the réduction system developed earlier in Spanish America. As such, he includes not only Paraguay but also Nueva España, now called Mexico, as models. The problem with this argument is the lack of Christian 'reducciónes' in Nueva España, where native villages or pueblos already existed. What Jaenen seems to suggest is that the French Jesuits were familiar with the Spanish segregation of Amerindians in sixteenth-century Nueva España. Similarly Carole Blackburn refers to the sixteenthcentury missionary communities in the Philippines where Spanish friars reorganised the indigenous population for effective cultural assimilation and religious instruction. Regrettably these two alternatives for a revised perspective lack sufficient documentation. In addition, Jaenen points to the Récollet Franciscan example of segregating the indigenous Laurentian peoples in order to provide them with Christian instruction. This was before the Jesuits joined the Franciscan mission in Quebec. Although all these examples and interpretations may demonstrate indirect influences upon the Jesuit attempts to segregate Amerindians in mission villages, they provide no theoretical

${ }^{4}$ A Member of the Ursuline Community [Mother Sainte-Croix, principally], Life of Madame de la Peltrie (Magdalene de Chauvigny) (New York: Edward Duignan \& Brother, 1859), 73; A Member of the Ursuline Community [Mother Sainte-Croix], Glimpse of the Monastery (Quebec: C. Darveau, 1872), 14; Gabriel Gravier, Vie de Samuel de Champlain: Fondateur de la Nouvelle-France (1567-1635) (Paris: Librarie orientale \& américaine, 1900), 93; Joseph Edmond Roy, M. de Montmagny (Québec: L'Événement, 1906), 41; Bruce G. Trigger, The Children of Aataentisic (Kingston \& Montreal, McGill-Queen's University Press, 1976), 468, 577-78 \& 685; John Webster Grant, Moon of Wintertime (Toronto: University of Toronto Press, 1984), 27 \& 58; Carole Blackburn, Harvest of Souls (Montreal \& Kingston: McGill-Queen's University Press, 2000), 94-95; Marc Jetten, Enclaves amérindiennes: les «réductions» du Canada, 1637-1701 (Sillery: Septentrion, 1994), 15-33; and Jean-Jacques Simard, La Réduction (Sillery: Septentrion, 2003), 26-27 \& note 3. 
antithesis to the popular notion that French Jesuit réductions were directly based on the Jesuit reducciónes in Paraguay. ${ }^{5}$

Most historians of New France have been, or wish to be, content with having found a prototype for Canadian réductions in Paraguay. They have not asked whether the missionaries in Paraguay created the reducción scheme from scratch or developed it from a prototype in some other Jesuit mission. These historians should go one step further, for they only argue that all the elements in the Jesuit operations of the réductions originated in the Paraguayan system.

The Paraguayan experiment, however, was merely one of several Jesuit missions in non-Christian regions from the mid-sixteenth to the early seventeenth century. Therefore, it is difficult to believe that the French Jesuits, in their plan to introduce réductions to New France, learnt nothing from the experiences of other regions of the world. One thus needs to consider the possible models for the New France réductions outside Paraguay.

\section{The Prototypes beyond Paraguay}

The common way to determine the prototype for the Paraguayan missionary communities has been to look for precedents in the sixteenth century, a rather narrow approach that finds precedents in the Iberian colonies, such as the Dominican experiment in the Island of Española in the Caribbean; and the Spanish-managed indigenous communities called 'pueblos reales' in Central Mexico, Peru, and Bolivia. ${ }^{6}$ Other partial precedents include the colonial Spanish policy of 'congregación' in Central and South America, where Spanish officials amalgamated numerous villages in order to facilitate tribute collection and the organisation of labour conscripts. Also, in the Portuguese colony of Brazil, the colonial officials helped the Jesuit missionaries to create native Christian communities, or 'aldeias', near white settlements. ${ }^{7}$ All

${ }^{5}$ Jaenen, Friend and Foe, 177-78; and Blackburn, loc. cit.

${ }^{6}$ Raymond A. Bucko, 'Bartholomé de Las Casas, 1474-1566', Early Encounters in North America: Biography (n.p.: Alexander Street Press, L. L. C.; \& the University of Chicago, 2004, online: www.alexanderstreet2.com/EENALive/bios/A6919BIO.html); and Robert H. Jackson, 'Jesuit Frontiers: A Comparison of the Development of the Two Missions in Baja California and Paraguay', in San Jose de Comondu, 1708-1808 (online: www.timsbaja.com/rjackson/0200703/loretomissionscomparison.html).

7 Stafford Poole, 'Iberian Catholicism Comes to the Americas', in Charles H. Lippy et al., Christianity Comes to the Americas, 1492-1776 (New York: Paragon House, 1992), 1-129, esp. 98-100; Robert H. Jackson and Edward Castillo, Indians, Franciscans, and 
these precedents indicate that the Paraguayan reducciónes were at least not unique as settlements for Amerindians but were consistent with government policy in colonial Latin America.

The Jesuit system of reducciónes in Paraguay, however, had a distinctive character that set a precedent for New France. Unlike the sixteenth-century precedents in the Spanish colonies, this missionary scheme in Paraguay either lacked the goal of incorporating indigenous people into European society or gave less priority to it. ${ }^{8}$ To use a computer metaphor, the reducción scheme shared its hardware-the physical native settlements-with the sixteenth-century colonial and evangelistic experiments, but it did not share with them its softwarethe exploitation of the native population. Where then did the software for Paraguayan settlements come from? This is the type of question that historians of the Canadian and Paraguayan missions have not asked when considering the Jesuit missionary settlements.

There are two ways to search for the conceptual prototypes for the reducciónes. One is to consider the motive of the missionaries for segregating their existing and potential converts from European settlers. By establishing isolated indigenous communities, the Jesuits tried to facilitate the process of evangelisation by ridding themselves of all the hindrances caused by the colonial 'encomienda' system, which allowed the Spanish colonists to force the Amerindian peoples to become serfs. Beyond this system, however, the native men they exploited and the indigenous women they forced into concubinage. Consequently the colonists hindered the missionaries' attempts to convert the native people to Christianity. ${ }^{9}$ And yet this social conflict is still insufficient to explain why the Jesuits created the reducciónes. Therefore, one needs

Spanish Colonization (Albuquerque: University of New Mexico Press, 1995), 6; and Dauril Alden, The Making of an Empire: The Society of Jesus in Portugal, Its Empire, and Beyond, 1540-1750 (Stanford, CA: Stanford University Press, 1996), 72-73.

${ }^{8}$ Poole, op. cit., 99.

9 Antonio Ruiz de Montoya, The Spiritual Conquest (1639, St. Louis: The Institute of the Jesuit Sources, 1993), chap. 6, 39-40; A. Huonder, 'Reductions of Paraguay', in vol. 12 of The Catholic Encyclopedia (online); Philip Caraman, The Lost Paradise (London: Sedgwick \& Jackson, 1975), 35. Unlike Montoya, neither Huonder nor Caraman provides concrete examples of the Spaniards' negative influence even though both of them pointed to the European immorality in the colonies. Although the Amerindians in Asunción seem to have been robbed by Spanish settlers, even Montoya avoided describing clearly who-native serfs or fellow European settlers or both-became the victims of their robbery. 
to ask one further question: When and where did the missionaries think of creating isolated missionary communities?

There is one field of missionary activity that hitherto has been overlooked. In the Spanish Jesuits' accounts of Paraguay, there is evidence that the Jesuits there admired the missionaries of Japan. ${ }^{10}$ One passage by an early missionary points to the Jesuit experience that inspired the Paraguayan missionaries. La conquista espiritual by Father Antonio Ruiz de Montoya is an early account, published in 1639, of the Paraguayan missions. Father Montoya, who, from 1612 to 1637, played a leading rôle in establishing the early reducciónes, referred to the Japanese Christian communities as models for the Christian settlements in Paraguay. He praised Japan's 'houses and palaces', 'civilisation' and gorgeous 'silks', as well as the country's 'costume', its 'variety in food' and its 'luxuries.' He also respected its 'martyrs' who were killed for converting to Christianity. At the beginning of his description of the Paraguayan reducciónes, a description which formed almost half of the account, Father Montoya expressed a great admiration for the Japanese Christian communities, which he held up as the model to be emulated by his companions. ${ }^{11}$

Two names given to the early seventeenth-century reducciónes suggest this Japanese influence on Paraguay. One name was that of 'San Francisco de Xavier', which was located along the Uruguay River. Even though Father Xavier's name was widely used for European institutions, he was noted particularly for his pioneer work in Japan, as already discussed in the second and third chapters. The other name that evoked Japanese connections more strongly was 'Los Santos Mártires de Japón'. Situated between the Paraná River and the Uruguay River, this second community was dedicated to the Jesuit martyrs of Japan, including Miki Paulo, Kisai Diego and Gotô Johannes, who were crucified in Nagasaki in 1597 on the orders of Toyotomi Hideyoshi. ${ }^{12}$ Therefore, it is worthwhile to consider the methodological similarities

${ }^{10}$ Emilio E. Ravignani \& Carlos Leonhardt, SJ (eds.), Iglesia: Cartas annuas de la Provincia del Paraguay, Chile y Tucumán, de la Compañía de Jesús (1609-1614) (Buenos Aires: Casa Jacobo Peuser, 1927) [Iglesia (1609-1614), henceforth], 233; Emilio E. Ravignani \& Carlos Leonhardt, SJ (eds.), Iglesia: Cartas annuas de la Provincia del Paraguay, Chile y Tucumán, de la Compañía de Jesús (1615-1637) (Buenos Aires: Casa Jacobo Peuser, 1929) [Iglesia (1615-1637), henceforth], 16.

${ }_{11}$ Montoya, op.cit., chap. 45, 129-30.

12 Ravignani \& Leonhardt, Iglesia (1615-1637), 680, 774 \& note 62; and J. MacNaspy, SJ, Lost Cities of Paraguay (Chicago: Loyola University Press, 1982), 88. 
between the Japanese mission and the Paraguayan mission before doing the same between the reducciónes and the réductions.

\section{B. A Comparison between Japan and Paraguay}

A comparison between Japan and Paraguay will answer the first question of whether the idea for the reducciónes was created without precedent. This approach requires the identification of the missionary villages or towns in Japan, since Christianity was accepted only on a local scale. The possible Japanese prototypes for the Paraguayan reducciónes are the villages of the pro-Christian daimyô in western Kyushu, especially those ruled by the Ômura and Arima clans in the region of Hizen, today's Nagasaki and Saga Prefectures. Ômura Sumitada was baptised in 1563, and Arima Harunobu in 1580. Once they understood that the daimyô were co-operating with the Jesuits, the ordinary people in Hizen welcomed the missionaries. In 1574, Ômura Sumitada even began to order all his vassals and territorial residents to seek baptism, as he had already done. ${ }^{13}$

There are similarities between the Paraguayan reducciónes and the Hizen villages, suggesting that the Jesuit experiment in Paraguay was not the first attempt at creating an independent Christian community among non-European people. Prior to the Paraguayan experiment, the Society of Jesus succeeded in creating what became a model evangelisation programme in Japan. To achieve success, it was important that the Hizen villages did not coexist with European settler colonies. Importantly the Jesuits eschewed European-style military conquest as a necessary prerequisite to missionary work. Prior to contact with Japan it was always thought necessary to conquer a nation militarily before beginning the process of acculturation, especially in the Spanish colonies.

A further comparison is possible if based on eight main characteristics of the missionary communities in Paraguay, as stated in order below. To begin with, the Paraguayan settlements, following the example of Japan, were located far from the Spanish and Portuguese

${ }^{13}$ Luís Fróis, Historia de Japam (ed. José Wicki, SJ, Lisboa: Biblioteca nacional de Lisboa, 1976-84), part I, chap. 104 [Historia, 1: 104, henceforth]; and Matsuda Kiichi \& Kawasaki Momota (eds.), Nopponshi (12 vols., Tokyo: Chûôkôron-sha, 1977-80), vol. 10, $9-24$. 
settlements. The Jesuit missionaries established San Ignacio Guazú, the first reducción of the Society, in 1609. Fathers Marcial de Lorenzana and Francisco de San Martín travelled with indigenous chiefs and their people in search of this site, which was appropriate for their first attempt at creating sedentary communities for these migratory hunters and gatherers. By segregating Amerindians in this way from Iberian colonists, including Europeans born in South America, the Jesuits set up thirteen other native towns by $1630 .^{14}$

Similarly the Hizen villages were segregated, admittedly not by deliberate choice, from the Iberian settlements in East Asia, such as Macao and the Philippines. Although the means to these ends were dissimilar, the missionaries in both Paraguay and Hizen succeeded in establishing Christian communities independent of European colonies. The Japanese communities were originally non-European villages and were not subject to the Iberian colonists. The closest Iberian neighbours were the seasonal merchants and sailors at such trading ports as Nagasaki, Yokoseura and Kuchinotsu. Through the daimyô's patronage and political authority, the Jesuit missionaries converted existing sedentary villages into communities for Japanese Christians.

Second, the Jesuits established a kind of political autonomy in both Hizen and Paraguay. In Paraguay the foundation and development of the reducciónes occurred with the consent of the Spanish king, who authorised royal decrees and privileges. The native settlements were formally under the control of the colonial administration at Asunción. And yet two factors worked in favour of the mission. First of all, the colonial Europeans were denied access to the reducciónes and were unable to acquire any land in them. The second was that, while preserving the authority of caciques, or native headmen, the missionaries in the settlements took on the duties of civic and religious leaders beyond the authority of the caciques. ${ }^{15}$ Consequently the Jesuits maintained the autonomy of their missionary towns inside Paraguay as though they were located beyond the limits of Spanish colonial claims.

${ }^{14}$ The reducción of San Ignacio Guazú was free from lifetime slavery. Unlike other reducciónes established later, however, this first settlement remained subject to seasonal labour for the encomienda system in the Spanish outpost of Asunción, located nearly two hundred and fifty kilometres on a straight line to the north. See Sélim Abou, The Jesuit 'Republic' of the Guaranís (1609-1768) and Its Heritage (New York: The Crossroad Publishing Company, 1997), 34-36; Huonder, loc. cit.; and Montoya, op. cit., chaps. $1 \& 5,29-30 \& 37-38$.

${ }_{15}$ Caraman, op. cit., $111,120 \& 157$. 
This attempt at political autonomy outside any European colony had already proved successful in the port town of Nagasaki in Hizen. In 1580, Ômura Sumitada granted this port and the neighbouring villages and towns to the Jesuit missionary order, just as he entrusted the administration of his other feudal holdings to his vassals. ${ }^{16}$ Although Ômura retained the right to impose a tariff on international trade, the Jesuits gained control of international trade at the port as well as the privilege of local taxation. The only difference from other Hizen villages was that Nagasaki was inhabited by both Japanese residents and foreign visitors. The Jesuit administration of Nagasaki was probably the first example of political autonomy that the Society obtained outside European colonies.

Third, the missionaries attempted to create a self-sustaining agrarian society in the Paraguayan reducciónes. As long as the indigenous people were obliged to seek their means of sustenance in the forest or on the plain outside a permanent settlement, the Jesuits were unable to provide them with Christian instruction as thorough as they might provide for a sedentary population. For example, once settled in the reducciónes, the semi-sedentary Guaraní people, who lived all over colonial Paraguay learnt systematic agriculture and animal husbandry. ${ }^{17}$ Their farms produced maize, cassava, sweet potatoes, sugar cane, yerba mate tea, fruit, cotton and different types of vegetables. Their domestic animals included oxen, cows, sheep and horses. This selfsustaining economy was also strengthened by the foundation of domestic industries, such as carpentry, metalwork, painting, shoemaking and textiles. ${ }^{18}$

In Hizen, on the other hand, the sedentary and self-supporting agrarian standard was already a fait accompli before the Jesuits arrived. The local Hizen communities were basically agriculturalists, although a part of the population was engaged in fishing, hunting and crafts.

${ }^{16}$ Lourenço Mexia's annual report of 1580 to the general superior, from Bungo, 20 October 1580, in Matsuda, Hôkokushû 3, 5: 217-65, esp. 238-39.

${ }^{17}$ It is difficult to label the seventeenth-century Guaranís nomadic or sedentary in black and white. They lived in small villages in the woods and engaged in horticulture. And yet they did not remain in one spot permanently and periodically wondered in the woods like nomads. See Montoya, op. cit., chap. 10, 48-51; Maxime Haubert, La vie quotidienne des Indiens et des Jésuites du Paraguay au temps des missions (Paris: Hachette, 1967), 12-13; and R. B. Cunninghame Graham, A Vanished Arcadia (London: William Heinemann, 1901), 26-27.

${ }_{18}$ Abou, op. cit., 77-79; Caraman, op. cit., 117-18; and Huonder, loc. cit. 
The warm climate produced fruits and nuts. Farmers raised poultry, oxen, goats and horses. The fields were used for growing vegetables and different kinds of cereals, especially for rice and wheat. Thus, the missionaries did not have to introduce farming to their Japanese congregation, nor did they have to organise new settlements. Therefore, the experience in Hizen showed that the creation of Christian villages was possible when non-Europeans were settled in one place.

Fourth, the missionaries in Paraguay introduced clothing to the residents in the reducciones. The cotton grown in the settlements was collected and distributed to the women in charge of spinning, and it was then handed over to workers in the weaving house to be made into clothing for inhabitants. Wool was also spun and fashioned into clothing for use inside the towns. ${ }^{19}$ Having previously been half-naked in the forest, the residents of the towns were turned into neatly-dressed Christians, whom Father Montoya admired as model Christians similar to Japanese proselytes. ${ }^{20}$

Once again, there was a Japanese model. As far back as the sixteenth century and before European contact, ordinary Japanese had been dressing in simple clothing made from flax and cotton. The missionaries placed a priority on tidy clothing. When Father Xavier arrived in Kyushu in 1549, he seems to have accepted Japanese clothing as a matter of course, so much so that he did not even mention clothing in his reports. He simply praised the people as good candidates for becoming Christians. In 1583, Father Alessandro Valignano referred to the cleanliness of Japanese clothing. That was his way of labelling the Japanese as an ethnic group already suited for evangelisation. ${ }^{21}$

From a European point of view, clothing implied Christian decency and moral propriety. For the priests in Paraguay, covering part of the body with clothes was more important than the manufacture of

${ }_{19}$ The surplus cotton fabric and wool was exported to the urban Spanish centres. See Abou, op. cit., 80.

${ }^{20}$ Montoya, op. cit., chap. 45, 129-30.

${ }^{21}$ Joan Rodorigesu [João Rodriguez-Tçuzu], Nippon kyôkaishi (2 vols., Tokyo: Iwanami Shoten, 1967), vol. I, 272-73 \& 403-20; Francisco de Xavier, to his companions living in Goa, from Kagoshima, 5 November 1549, in M. Joseph Costelloe, SJ (ed.), The Letters and Instructions of Francis Xavier (St. Louis, Missouri: The Institute of Jesuit Sources, 1992), epistola [ep., hereafter] 90, p. 297; in Kôno Yoshinori, SJ (ed.), Sei Furanshisuko Zabieru zenshokan (Tokoyo: Heibon-sha, 1985) ep. 90, p. 471; and Matsuda Kiichi et al. (eds.), Nippon junsatuki (Tokyo: Heibon-sha, 1973), 11-14. 
clothing. Thus, the Jesuits in Paraguay expected their Amerindian converts to follow the Japanese example of being fully clothed.

Fifth, Father Montoya in La conquista espiritual considered permanent buildings as an important element for beginning a Christian life. Accordingly the Jesuits required indigenous people to construct church buildings and houses in the reducciónes, using stones and bricks. The Guaranís originally lived in large rectangular huts, and each hut could accommodate up to two hundred people. The Christian towns adopted a system of block housing units, separated from one another, one unit per nuclear family. Each unit comprised six to eight rooms. ${ }^{22}$

The Japanese buildings, or 'houses and palaces,' to use Montoya's terms, were wooden structures. In Historia da Igreja do Japão, a Jesuit account of sixteenth- and seventeenth-century Japan, Father João Rodriguez-Tçuzu, praised the art and technique of Japanese architecture as one of the best wooden construction styles anywhere. Although there were no palaces in Hizen villages, except the Ômura and Arima castles, these first Christian communities were run independently by non-Europeans. These communities were as fully equipped with public and private architecture, all well landscaped, as any European community. ${ }^{23}$

Sixth, in Paraguay, the reducciónes were guided by Christian missionaries and yet were administered locally by indigenous residents. Before contact and conversion, the Amerindian cacique was the absolute master of his subjects in each hamlet. Because there was no government system beyond the hamlet level of each cacique, the Jesuit missionaries had to create a wider administrative structure to facilitate their ecclesiastical control over the large population. For that, they adopted a Spanish, but not a Japanese, ruling system. Below the level of Jesuit control, they set up a municipal council that exercised legislative, executive and judicial powers. Based on the results of elections, overseen by the Jesuits, the council membership consisted of prefects, vice-prefects, judges, neighbourhood delegates, royal standard-bearers, policemen, notaries and so forth. Finally, under these two levels of government, there was a third level, a conventional one represented by the caciques who numbered nearly fifty within each reducción. ${ }^{24}$

22 Montoya, op. cit., chap. 45, 129-30; Abou, op. cit., 69-70.

23 Rodorigesu [Rodriguez], op. cit., vol. I, 323-25; \& vol. II, 49-53.

24 Abou, op. cit., 74-75; and Caraman, op. cit., 158. 
There was no need to introduce the Iberian ruling system to Japan. The Jesuit evangelists in the Hizen communities both retained the administrative system managed by non-Europeans and had the high social status attributed to foreign inhabitants, traits the later Paraguayan mission would later emulate. Although the priests in Paraguay had to establish a local administration by creating a superstructure that had been completely lacking in the tiny forest communities, their Jesuit predecessors in Japan had to create no such thing, for it already existed. As Father Valignano observed, local Japanese society had a land-based hierarchical structure controlled by a daimyô at its summit, who ruled local vassals directly and civilians indirectly. Being under the rule of daimyô, Buddhist and Shintô priests independently maintained their own high status. Thus, the missionaries took advantage of this existing hierarchy.

Buddhist priests were near the top of the social hierarchy. The Jesuits tried to supplant these priests with Christian priests. In 1574, for example, Father Gaspar Coelho persuaded the daimyô Ômura Sumitada either to eliminate temples and shrines throughout his territory or to reassign them for church use. According to Father Frois, under the rule of Ômura, over forty temples were destroyed and as many churches were built on their sites. Under orders from the daimyô, even Buddhist priests and apprentices were converted to Christianity and became members of the Christian community. As early as 1582, Father Frois boasted that the entire population of sixty thousand in Ômura were Christians. In this manner, the Jesuit missionaries ultimately gained administrative control of Christian villages even though their approach was not the same as that of the priests in Paraguay. ${ }^{25}$

The seventh similarity between Japan and Paraguay was that indigenous people assisted in the work of the Church in both places. The rôles performed by non-European assistants were not Jesuit inventions but were similar to those developed by the Church assistants in Europe. The priests were assisted by those of lower ranks in the

${ }_{25}$ Matsuda Kiichi et al (eds.), Nippon junsatuki, 7-10; Fróis, Historia, 1:104; Matsuda, Furoisu Nipponshi, vol. 10, 9-24; Francisco Cabral to the superior of Portugal, from Nagasaki, 12 September 1575, in Matsuda, Hôkoku-shû 3, 4: 249-56; Kudamatsu Kazunori, Kirishitan denraichi no jinja to shinkô (Ômura, Nagasaki: Tomimatsu jinja saikô yonhyakunen jigyô iinkai, 2002), 120-50; Luis Frois's annual report of 1587, from Arima, 20 February 1588, in Matsuda, Hôkokush û 3, 7: 159-242, esp. 186-89; and Luis Frois's annual report of 1582 to the Jesuit general superior, from Kuchinotu, 31 October 1582, in Matsuda, Hôkokushû 3, 6: 83-116, esp. 83-84. 
holy orders in Europe, such as deacons, subdeacons, and acolytes in the Church or brothers in religious orders. Yet the active recruitment of non-European helpers, who had formerly been non-Christians, to Church services was not thought of when the Jesuit missions were solely within Europe.$^{26}$ Also, the non-European assistants were outside holy orders and normally had no chance to become priests, and thus were different from those Europeans in holy orders. ${ }^{27}$ Therefore, nonEuropean participation in the ecclesiastical work was one of the earliest successful experiments in the foreign missions by the Jesuits.

The missionaries in Paraguay ran their reducción church with the help of a tiny number of priests and coadjutant brothers, who were assisted by native catechists. As late as 1629 , each settlement was equipped with only two missionaries: one senior priest and one younger assistant priest or brother. The elder of the two remained in residence while the younger made preaching trips into the countryside. ${ }^{28}$ From the outset, the missionaries employed native catechists, or catequistas, who could communicate with settlers in their native language for Mass and religious instruction, a fact that is mentioned in the annual reports, Las cartas anuas. ${ }^{29}$ As the number of converts increased, the Jesuits recruited native teachers to teach children reading, writing, dancing, singing and playing musical instruments. Most children were educated in their native language by the indigenous staff. ${ }^{30}$

The Church in Japan survived with even fewer priests. The missionaries there constantly relied on Japanese coadjutors. As late as 1585, when the mission was thirty-six years old, approximately eighty Jesuit

${ }^{26}$ The help of foreign assistants in the missions is reminiscent of the expansion of the Christian Church in the ancient and medieval centuries, such as the Roman Catholic missions to the ancient Germans in Western Europe and the Greek Orthodox mission to those non-Greeks in Eastern Europe.

${ }^{27}$ In this sense, dôjuku may have been similar to sacristans in Europe, who were lay assistants in charge of the sacred vessels and vestments. There was at least one attempt at solving this lowly treatment of non-European assistants. Father Alessandro Valignano attempted to amend the rules for the Jesuit priesthood in Japan in order to increase the number of Japanese priests in the 1580s.

${ }^{28}$ Caraman, op. cit., 56-57, 138-139; and Graham, op. cit., 198-99. Even in later periods, the reducciónes had a staff of three missionaries at most. See Abou, op. cit., 74 .

${ }_{29}$ See, for example, the reports of 1611,1612, 1613, 1614, 1616 and 1617, edited in Ravignani \& Leonhardt, Iglesia (1609-1614), esp. 118, 194, 272, 425, 443, 470, 525; and Iglesia (1615-1637), 81, 86, 103 \& 134.

30 Only those deemed bound for bureaucratic careers learned Spanish, and even fewer gifted students learnt Latin. See W. H. Koebel, In Jesuit Land (London: Stanley Paul \& Co., 1912), 236-38; and Abou, op. cit., 86-88. 
fathers and brothers were in charge of no fewer than two hundred church buildings and over one hundred and fifty thousand Christians. ${ }^{31}$ In 1582, only four priests and three brothers, including two Japanese lay brothers, were in charge of sixty thousand Christians in Ômura. ${ }^{32}$ In other words, Jesuit priests were often absent in many local Christian communities.

To overcome this shortage of religious staff, the missionaries created two lay positions, the dôjuku and kanbô. 'Dôjuku', spelt 'dogicos' or 'dojiqus' in the Iberian correspondence, was originally a term that designated a Buddhist novitiate in Japan. Among the numerous assisting offices for the priests of the European Church, the Jesuits seem to have used the term to mean oblates or donnés, who dedicated themselves to a monastic life in a religious order, especially in mediaeval Europe, without taking religious vows. ${ }^{33}$ Despite some similarity, dôjuku assistants were not equivalent to deacons or subdeacons because the Jesuits introduced these two European types of offices to the Japanese church later in the seventeenth century. ${ }^{34}$ According to Father Valignano, the Jesuits borrowed a Japanese word and called their lay assistants 'dogicos'. ${ }^{35}$

Dôjuku assistants were co-opted by the Jesuits to act as Japanese lay brothers serving as interpreters, preachers, couriers and secretaries in the missions. This new type of subordinate provided religious services and preached in the native language on behalf of European priests. Their duties included the maintenance of church buildings and

${ }^{31}$ Alessandro Valignano to Don Teotonio de Bragança, Archbishop of Evora, from Goa, 23 December 1585, in Murakami Naojirô (trans.), vol. II of Iezusukai Nippon nenpô (2 vols., Tokyo: Yûshô-dô, 1969), 133-37 [Nenpô, 2: 133-37, henceforth]; and Lourenço Mexia to Miguel de Souza at Coinbra, from Macao, 6 January 1584, in Matsuda, Hôkokushî 3, 6: 285-94. This figure of eighty fathers and brothers included thirty priests, twenty-five Portuguese brothers and twenty-five Japanese lay brothers.

32 Luis Frois's annual report of 1582 to the general superior of the Society, from Kuchinotsu, 31 October 1582, in Matsuda, Hôkokush û 3, 6: 83-116, esp. 83-84.

${ }^{33}$ Josef Franz Schütte, SJ, Valignano's Mission Principles for Japan (2 parts, The Institute of Jesuit Sources, 1980-85), part one, 340; \& part two, 39-40.

${ }^{34}$ In Japan, the offices of deacons and subdeacons appeared as late as the seventeenth century. Subdeacons are mentioned probably for the first time in 1612; in Father João Rodrigues Giram's annual report of 1611, to the general superior, from Nagasaki, 10 March 1612. Deacons appeared in Father Rodrigues Giram's annual report of 1612, from Nagasaki, 12 January 1613. See Matsuda, Hôkokushû, 2nd series, 1: 195-384, esp. $205 \& 283$.

${ }^{35}$ In his Sumario de las cosas de Japón, Father Valignano wrote that the Jesuits called their lay assistants 'dogicos/dojiqus' in a Buddhist fashion. See Matsuda Kiichi et al, Nippon junsatsuki (Tokyo: Heibon-sha, 1973), 88-91. 
secretarial paperwork in Japanese. They also performed any domestic work that European missionaries were incapable of doing, such as the preparation of the tea ceremony and receiving Japanese guests. As late as the 1580s, the dôjuku included juvenile domestics, assistants for church services as well as more privileged or elderly preachers. ${ }^{36}$

In the early seventeenth century, the Jesuits began to use another term, kanbô, to differentiate a certain type of lay assistant from dôjuku. Kanbô was a term applied specifically to Japanese assistants who took care of the churches. Originally it referred to caretaking priests of a Buddhist temple. The kanbô were tonsured and at first informally called bonzes because some of them were ex-Buddhist priests. They looked after church buildings but did not accompany missionaries on their journeys. Similar to the domestic duty of dôjuku, their tasks included teaching basic Christian doctrine, looking after the religious activity of the community and helping the sick and the dying. ${ }^{37}$

Finally one last similarity between the missions in Japan and those in Paraguay was the treatment of the diseased. The Jesuit evangelists in both regions did little to prevent the spread of epidemic diseases. Here again, Japan served as a model. For centuries, the location of Japan at the eastern edge of Eurasia facilitated communication with the continent. Thus, the bacteria and viruses brought by the Europeans were familiar to the Japanese. According to the missionaries' occasional references to illness, the ailments and symptoms encountered by the priests were all personal afflictions and not part of a widespread epidemic. These isolated cases of disease and handicaps included unspecified fevers, hernia, tumours, tonsillitis, swelling of limbs, stomach ache and agerelated diseases. ${ }^{38}$ Since there were no major epidemics in Japan, the Jesuits did not have to give thought as to how to control them. The evangelists even experienced a prototypical precedent for not having

\footnotetext{
${ }^{36}$ Matsuda, Nippon junsatuki, 90-91; and Gonoi Takashi, 'Iezusukai hikaiin no konguregasan to kaisôka', Shigaku zasshi 103 (1994): 35-73, esp. 40-42.

${ }^{37}$ According to Gonoi Takashi, Father Luis Cerqueira, bishop of Japan, called the bonze assistants 'kanbô', in his letter from Nagasaki, of 12 January 1603. A part of this letter is quoted in Gonoi Takashi, 'Kirishitan jidai no kanbô ni tsuite', in Kirishitan kenkyû 19 (1979), 239-62. See also Josef Franz Schütte, op. cit., part one, 231-32, and part two, 172-73, 205-06 \& 211-12.

${ }^{38}$ See, for example, Fróis, Historia, 1: 50, 70, 96; 104, 110, 112; 2: 45, 90; \& 3: 2; and Matsuda, Furoisu Nipponshi, 9: 147-48, 243-44, 341-43; 10: 18, 60, 91-92, 277; 11: 77 \& 364-65.
} 
to prevent the potential damage of European-oriented diseases to the peoples on the formerly non-Christian side of the earth.

In Paraguay, the judgements made and solutions found by the Jesuits in dealing with illness and invalids were based on what the evangelists in Japan had observed. The missionaries endeavoured to preserve and protect the freedom of the Amerindians against the bondage of the encomienda system, but they spent little or no time on preventing epidemics from being spread among the indigenous people. A plausible guess, reasonable at least from a twenty-first century standpoint, is that the priests might have attempt to minimise the effect of diseases by segregating Amerindians, as supported by Philip Caraman. ${ }^{39}$ Yet it is difficult to find any references that support this speculation in the missionary correspondence from Paraguay. For example, when Father Diego de Torres, the Jesuit Provincial of Paraguay, dispatched missionaries to create reducciónes in 1609, his written instructions focussed on how to build native settlements that were independent of serfdom, and not at all on how to prevent fatal diseases among Amerindians. Also, in La conquista espiritual, Father Montoya ascribed the numerous deaths of native slaves solely to the hard labour and the miserable treatment by Spanish colonists in the encomiendas. ${ }^{40}$

Never once did Father Montoya consider epidemic diseases responsible for the decrease of native population, even though the segregation must have accidentally served to reduce the Amerindian mortality. Instead, he attributed the decline of the reducción populations mostly to the exhaustion and famines caused by battles, long travels and meagre harvests. These factors blinded him to the effect of alien diseases. His response to the population decrease in La conquista espiritual was thus narrow and limited. When slave hunters, or bandeirantes, ${ }^{41}$ destroyed eleven out of the thirteen pioneer reducciones in the region of Guairá by 1631, the Jesuits evacuated the settlers in the remaining settlements of Loreto and San Ignacio Miní on the shore of the Yavevirí in the present-day province of Misiones. Out of the twelve thousand residents who departed and travelled up to three hundred kilometres,

${ }^{39}$ Caraman, op. cit., 34. Without source evidence, Caraman asserts that the Jesuits segregated the Guaranís to protect them from epidemic diseases.

40 Abou, op. cit., 134; and Montoya, op. cit., chap. 7, 40-43.

41 The residents in Portuguese Brazil formed a militia at São Paulo to capture the indigenous people and sell them as slaves in Brazil. The members of such militias were Portuguese, half-breed, or even native Tupís, and were named bandeirantes, paulistas, and mamelucos. See Abou, op. cit., 157. 
only four thousand reached the new sites. Along the way, two thousand died of hunger or disease. Others deserted or were killed or captured by European colonists. Because another two thousand settlers succumbed to hunger and malady after settling down, less than one thousand survived in each of the two reducciónes. ${ }^{42}$

From the outset, the reducciónes witnessed outbreaks of diseases. The cartas anuas, the annual correspondence of Paraguay from 1609 to 1638 , report on the repeated harm to native residents caused by pestilence, fever, dysentery, smallpox, influenza, scarlet fever, measles and typhus. The seventeenth-century terminology makes it difficult to determine whether a disease was of European origins or indigenous. Furthermore, it may also be a mistake to ascribe every single outbreak entirely to the occasional contacts with European colonisers or the frequent contacts with missionaries or to the introduction of European livestock within the settlements. Nonetheless, considering both the diseases' symptomatic similarity to existing European terms and the absence of outbreaks among the Japanese, one must conclude that they originated in Eurasia.

Considering the increasingly frequent references in the correspondence to the harmful effects of these diseases on the Amerindian population, one must conclude that the Europeans were unintentionally responsible for the spread of disease. Perhaps because they did not fully understand epidemics, the missionary response was to care for each individual case rather than looking for the root causes of the epidemics. After all, in Japan, where there were few if any epidemics caused by the introduction of European germs and viruses, that was exactly what they had done. ${ }^{43}$

Considering the above eight methodological similarities between the missionary experiment in Japan and the Paraguayan reducción scheme, it is difficult not to conclude that the Christian villages in Japan became an inspiration to the Jesuits who worked to establish

42 Montoya, op. cit., chaps. 35-39, 100-113; and Abou, op. cit., 44.

${ }^{43}$ Ravignani \& Leonhardt, Iglesia (1609-1614), 18, 47, 52, 57, 65, 71-73, 76, 81, 85, $90,98,101,105,134,162,215,347,425,452,457,492$ \& 521 (on diseases); 27, 43, 118, $168-71,182,185,188,195,202,205,213-16,289,294,318,332,375,385,425 \& 522$ (on caring for the ill); and Ravignani \& Leonhardt, Iglesia (1615-1637), 32, 88, 128, $140,146,152,177,183,187,204,206,210,213,216,248,251,356,369,388-389,398$, $411,426,433,444,455,461,482,493,496,511,523,531,534,539,543,593,618,640$, 653, 673-74, 681, 687, 692, 701-02, 705, 708, 713 \& 717 (on diseases); 22, 53-56, 103, $123,144,160,213,266,289,457 \& 523$ (on caring for the ill). 
similar sedentary Christian communities in Paraguay. The Jesuit missionaries in Paraguay had already borne certain preconceptions in mind when they began to create native Christian communities. As far as they were concerned, the reducciónes, just like Japanese Christian villages, ought to be isolated from European settlements, in order to maintain the political autonomy of the Jesuits ${ }^{44}$ and to create a selfsustaining agrarian society of fully clothed inhabitants living in houses, all this administered by indigenous residents. Also, the Jesuits in the reducciónes were as few in number as their predecessors in Japan. The Japanese experience taught them that the missionary church could only be managed with the assistance of Amerindian catechists. This initiative started in sixteenth-century Japan, where the early Jesuits recruited and trained Japanese lay brothers and dôjuku.

Through their experiments in Japan, the Jesuit missionaries seem to have learnt which criteria of Euro-Christian social standards to adopt and which to exclude, in order to create an independent Christian community outside the colonial European territories. Based on a few decades of experience with Japanese neophytes in the mid-sixteenth century, the Iberian Jesuits learnt to appreciate Japanese habits and traditions, such as an agrarian society, simple clothing styles and architectural techniques. The Jesuits also introduced new ideas, such as segregation of non-European converts from Europeans and political autonomy. The Jesuits in seventeenth-century Paraguay applied the same standards to the reducciónes although they were innovations in Paraguay, whereas in Japan, the Jesuits perpetuated what was already in place. This interconnection between Japanese Christian villages and Paraguayan reducciónes will help with an analysis of the réductions in New France.

${ }^{44}$ This claim of the isolation from European settlements as the precondition for the political autonomy of the Jesuits may need further explanation because the separation in Japan was unintentional. For the Jesuits, however, the port town of Nagasaki and the Christian villages in Hizen were the first foreign missionary communities that they established far from European settlements. They are likely to have learnt some advantages of the remoteness from European settlements in order to realise their own complete religious control over their converts' communities. 


\section{The Réductions in New France in Comparison with the Paraguayan and Japanese Models}

The indigenous Christian settlements established in mid-seventeenthcentury New France can now be examined from a broader perspective with roots not only in Paraguay but also in Japan. One way to understand the réductions is to see them as a development that started in Japan and continued in Paraguay, then was transferred to North America. Alternatively a variation is to examine the native Christian settlements in New France as a deliberate emulation of either Paraguay or Japan. The criteria needed for analysis include the eight similarities discussed above, as well as some others. By determining what degree the réductions emulated the Paraguayan models, it will become evident that the Laurentian réductions were not simple emulations of the Paraguayan reducciónes.

First, in terms of segregation, the réductions were different from the reducciónes, and were rather closer in nature to some Hizen villages. The native Laurentian communities, which numbered three in the mid-seventeenth century, were not as segregated as the Paraguayan models. The Innu community of Sillery, the first reserve in New France, was established in 1637 near the outpost of Quebec. It was only eight kilometres away from the port of Quebec by river. The réduction of La Conception, the second reserve, established in 1641 for the Algonquin, the Innu and the Attikamègue, actually bordered the French settlement of Trois-Rivières. From 1651 to 1656, the third settlement, a Huron settlement, was maintained on the Île d'Orléans, downriver from Quebec. All other réductions created later in the century were also within a radius of twenty-five kilometres from Quebec, Trois-Rivières or Montreal.

Located adjacent to Quebec, Sillery was never a settlement exclusively for Amerindians. The Jesuits created a parish at Sillery. At the end of 1647, sixty to seventy French parishioners resided there. The Amerindian and French settlers, however, seem to have simply coexisted separately from each other inside the settlement and shared few activities. In the Relation of 1647-48, Father Lalemant described High Mass in Sillery as an exceptional event, where both ethnic groups met and communicated with each other through an interpreter in order to learn of the Quebec governor's ban on the private liquor trade. In 1653, Father François-Joseph le Mercier regarded Sillery as a settlement for both the French and the Amerindians. Later in 1663, 
Father Lalemant distinguished the French settlement from the native réduction within Sillery. He regarded Sillery as the réduction for native Christians, and called the neighbouring French settlement 'the adjacent colony of the French'. ${ }^{45}$

The Paraguayan reducciónes, by contrast, were located farther away from the nearest Spanish outpost of Asunción. San Ignacio Guazú, one of the nearest settlements, lay two hundred and fifty kilometres away as the crow flies, or even farther, more than four hundred kilometres away, by way of the Paraguay and Tebicuary Rivers. The communities farthest away, Nuestra Señora de los Reyes de Yapeyú, created in 1627 near modern-day Uruguay, and San Miguel, established in 1626 beyond the Uruguay River in Rio Grande do Sul in what is now Brazil, were six hundred kilometres apart.

In terms of distance, the location of the Laurentian réductions was similar to that of the villages surrounding the port of Nagasaki. From the year 1580 onwards, the Jesuits had their regional headquarters in this port town and made missionary excursions to Hizen villages. Most Christian villages were within a radius of thirty kilometres from the port. In the same way, the French missionaries stationed in Quebec and Trois-Rivières commuted to or stayed in the neighbouring réductions.

Three major factors prevented the complete segregation of the Laurentian reserves. The most important factor was that the French colonists did not enslave Amerindians in the Iberian way, as in South America. As was the case in Japan, which was not conquered by Europeans, the missionaries found no need to segregate their converts from the French population. Furthermore, sailing along the Saint Lawrence over long distances was dangerous for the missionaries and even more so for the Christian nuns who helped with missionary work in the native réductions. The peoples in the Eastern Woodlands located in the regions north of Lake Ontario were at war with the Iroquois, who inhabited lands to the south of the Saint Lawrence. Because of their trading alliance with the Hurons, the French settlers had been threatened by the Iroquois, especially in the 1640s and 1650s when the fur trade increased. Furthermore, Amerindian réductions relied

${ }^{45}$ Jérôme Lalemant, Journal des Pères Jésuites en l'année 1640, in Relations 30: 203; J. Lalemant's Relation of 1647-48, in Relations 33: 49-51; François-Joseph le Mercier's Relation of 1652-53, in Relations 40: 203; and J. Lalemant to Gian Paolo Oliva, the general superior at Rome, from Quebec, 18 August 1663, in Relations 47: 253-55. 
initially on the human resources of French settlers, who cleared forests, cultivated land and built houses in order to prepare the reserves. ${ }^{46}$ Thus, it was a reckless idea to set up a réduction in a place distant from a French outpost.

Second, the Jesuits established their political autonomy in the missionary reserves, but the case of New France was a little different from its precedents in Paraguay and Japan. Notwithstanding the rôle of the missionaries in the management of the réductions, the settlements were officially under the direct control of the colonial French authorities. The Company of New France, in charge of the entire Laurentian colonisation until 1663, collaborated with the Jesuits in inducing the Amerindians to settle down near the French outposts. The company announced in 1639 that it would grant the same discounted prices to native converts as it gave to French settlers at its retail shop if they should choose to settle in Sillery. In addition, the Governor of Quebec induced the Algonquins in Sillery to maintain constancy in marriage and to elect chiefs to govern them in 1640. The governor later assumed the responsibility of prohibiting Sillery's native residents from buying liquor from individual Frenchmen as well as of urging them to embrace the Christian faith to remain in the reserve. The Jesuits seem to have been behind all these negotiations with Amerindians, since they referred to these actions as part of their missionary efforts in their annual reports. ${ }^{47}$

This slight difference was caused by the partial segregation of Amerindians. The réductions were located too close to the French outposts for the Jesuits to achieve complete autonomy. The reserve settlers thus obeyed two authorities: the Jesuits and the nearby civil authorities.

On the other hand, the Jesuit control of the Huron villages of Ihonatiria, Ossossané and Teanaostaiaé, was closer to the Jesuit autonomy in Paraguay and at the Japanese port town of Nagasaki. These pro-Christian or pro-French villages were not called 'réductions', since they existed before the mission was founded. However, the distance of these villages from the French settlements was similar to the distance of Paraguayan reducciónes from the Spanish settlements. These Huron communities of Christian converts were located seven hundred and

${ }^{46}$ Paul le Jeune's Relation of 1640, in Relations 18: 95-97 \& 109-111.

${ }^{47}$ Le Jeune's Relation of 1639, in Relations 16: 33; Le Jeune's Relation of 1640, in Relations 18: 99-101; and J. Lalemant's Relation of 1647-48, in Relations 33: 49-51. 
fifty kilometres from Quebec. Although the French missionaries were unsuccessful in converting the entire populations of these villages, they claimed that they had secured enough converts to consolidate their evangelistic activity. In these villages, so distant from any outpost, the Jesuits achieved independent governance over their Christian converts without the civil French authorities' interference in the mission. ${ }^{48}$

Third, the Jesuit attempts at settling down indigenous people in the réductions were not as effective as the Paraguayan reducciónes even though the missionaries had shared the same settlement goal ever since Father Xavier's mission. In terms of ideals, on the one hand, the attempts at creating a native settlement were the same as the predecessors' efforts in Paraguay and Japan. As early as 1635, Father Le Jeune expressed his hope for turning the Innu into a sedentary people. He acknowledged the importance of organising Amerindians into a village when he referred to the beginning of the residence of Saint Joseph in Sillery, in his Relation of $1638 .{ }^{49}$

In terms of lasting achievements, on the other hand, the French effort for Amerindian missionary settlements was a failure when compared with its Paraguayan and Japanese precedents even though, at first, there were some successes. As early as 1640, the Kichesipiirini, whom the French missionaries called the Algonquin of the Allumette Island, began to plant maize in Trois-Rivères, and so did the residents of Sillery. In April 1646, according to Jérôme Lalemant, native settlers prepared more than fifteen arpents of land in Sillery, and more than thirty indigenous families began farming in Trois-Rivières. Nevertheless, hunting won out over agriculture. In February 1643, the native settlers departed from Sillery for a moose hunt leaving only twelve or thirteen residents in one cabin, who were either invalids, old persons or children. The winter hunt for game remained so popular at the réductions that the missionaries referred to it repeatedly in the Journals of Jesuit Fathers and the successive Relations after $1642 .{ }^{50}$

48 J. Lalemant's Relation of the Hurons of 1642, in Relations 23: 43 \& 151; J. Lalemant's Relation of the Hurons of 1643-44, in Relations 26: 259-91.

${ }^{49}$ Le Jeune's Relation of 1635, in Relations 8: 55-57; and Le Jeune's Relation of 1638, in Relations 14: 205-07. See also Le Jeune' letter to General Superior Mutius Vitelleschi at Rome, from Trois Rivières, 1st August 1638, in Campeau, Monumenta, 4: 54-57, esp. 55 .

${ }^{50}$ Le Jeune's Relation of 1640, in Relations 18: 109-11; J. Lalemant, Journal des Pères Jésuites, en l'année 1640, in Relations 28: 185; Barthélemy Vimont's Relation of 1642-43, in Relations 23: 315-17; Vimont's Relation of 1643-44, in Relations 25: 161; Vimont's 
In other words, the Amerindians of New France remained heavily dependent on hunting wild game. It was, after all, part of their culture. Yet the Japanese residents in Hizen were already sedentary agriculturalists. The Guaraní settlers in the reducciónes were originally semi-sedentary horticulturalists even though they lived in the woods. In the seventeenth century, the native Laurentian peoples, by contrast, did not have permanent villages. The Innu and the Algonquin were, by nature, nomads. The Huron men who wintered in the réductions were semi-sedentary people, but they, too, normally hunted game in winter.

Moreover, two other major factors prevented the Amerindian settlers from cultivating sufficient food, which in turn made hunting necessary. ${ }^{51}$ First of all, repeated Iroquois raids during the 1640s and 1650 s, as noted by the Jesuit missionaries, rendered working in fields unsafe. ${ }^{52}$ In the spring of 1643, rumours of Iroquois incursions were enough to deter the community's participation in maize planting in Sillery. The male inhabitants were compelled to stop their agricultural work and depart for Fort Richelieu and Trois-Rivières to confront the Iroquois warriors. Although the native men returned to Sillery, they did not remain there. They again left for Tadoussac for hunting after failing to receive provisions from the French ships that were late in arriving. Also, in May 1656, Mohawk bands attacked the Huron settlers on the Île d'Orléans. The Hurons had set out for agricultural work in their fields after Mass. This réduction lost as many as seventy-one native settlers who were either killed or captured. Among them, many young women, vital participants in agriculture, were taken prisoner. ${ }^{53}$

Relation of 1644-45, in Relations 27: 143, 203-207; J. Lalemant, Journal des Pères Jésuites, en l'année 1647, in Relations 30: 157 \& 165; J. Lalemant's Relation of 1647, in Relations 30: 231-33; J. Lalemant, Journal des Pères Jésuites, en l'année 1648, in Relations 32: 107; J. Lalemant's Relation of 1647-48, in Relations 32: 267-69; and J. Lalemant, Journal des Pères Jésuites, en l'année 1649, in Relations 34: 65.

${ }^{51}$ Other factors that caused native farmers to emigrate may have included soil exhaustion, depletion of firewood and decrease of game animals in the locality. See Gabriel Sagard, Le grand voyage du pays des Hurons situé en l'Amérique vers la Mer douce, ès derniers confins de la nouvelle France, dite Canada (Paris, 1632) 117-18.

${ }^{52}$ E.g. Vimont's Relation of 1642-43, in Relations 24: 99-101, 157-59; Vimont's Relation of 1643-44, in Relations 25: 105-07; J. Lalemant's Relation of 1647, in Relations 30: 231; J. Lalemant's Relation of 1647-48, in Relations 32: 265-67; and Paul Ragueneau's Relation of 1651-52, in Relations 37: 181.

${ }^{53}$ Vimont's Relation of 1642-43, in Relations 23: 317-19; Le Jeune's Relation of 1656-57, in Relations 43: 115-19; and Paul Ragueneau to Goswin Nickel, general superior, from Quebec, 25 July 1656, in Campeau, Monumenta, 8: 801-03, esp. 802. 
As the other factor, the Amerindians were prevented from actively engaging in agriculture by the outbreak of diseases of European origin. The Hospital of Sillery received approximately one hundred native patients in one year starting in mid-1642, in other words one third of entire Amerindian population of three hundred. Such a high percentage suggests an epidemic caused by imported disease. Even though the figure of one hundred included the destitute in need of philanthropy in order to survive, they formed only a minority. The majority of the one hundred patients were convalescing from illnesses. At the same hospital during the same period, there were only five or six French patients, but they were all brought there after having being stricken with an endemic disease, limited to Fort Richelieu. In other words, it was not epidemic that laid them low. As for the native residents' recovery from illness, Father Vimont stated in 1643 that God only 'sometimes' restored their health. Four years later in January 1647, the Amerindian population of the reserve had declined to one hundred and sixty. All these examples taken together suggest that many native Christians in Sillery suffered heavily from epidemic disease that normally killed few French colonists because they were resistant to them. ${ }^{54}$

Fourth, unlike the Paraguayan model, the French priests did not teach spinning and weaving for the manufacture of clothing. They left the provision of clothes to religious philanthropy and barter. The Ursulines and Hospital nuns in Sillery provided Amerindians with food, clothing and shelter at every sort of charity. ${ }^{55}$ Linen, shirts, woollen caps and other clothes were given to native patients in the hospital of Quebec. ${ }^{56}$ Besides iron and other metal tools, French clothing, including hats, shoes, caps, woollens, shirts, linens and cloaks, were used for barter with Amerindians. ${ }^{57}$ The reason that the missionaries did not

${ }^{54}$ Vimont's Relation of 1642, in Relations 22: 155; Vimont's Relation of 1642-43, in Relations 24: 21-23 \& 159-61; and J. Lalemant, Journal des Pères Jésuites, en l'année 1647, in Relations 30: 155.

${ }^{55}$ Vimont's Relation of 1642-43, in Relations 23: 311-13; \& 24: 113; Vimont's Relation of 1643-44, in Relations 25: 243-45; J. Lalemant's Relation of 1647, in Relations 32: 213-15;

${ }^{56}$ See the invoices of supplies for the Hospital nuns, in Le Mercier's Relation of 1664-65, in Relations 49: 205-11; Le Mercier's Relation of 1665-66, in Relations 50: 161-63; and Le Mercier's Relation of 1667-68, in Relations 52: 107-09.

57 The Relations in the 1640 s and 1650 s describe trade items too briefly to list each of them, but the earlier documents are more detailed about barters. See Pierre Biard's Relation of 1616, in Relations 3: 69-70 \& 75-77; and Charles Lalemant to Jérôme Lalemant, from Quebec, 1st August 1626, in Relations 4: 207. 
teach cloth production on the reserves was that their introduction of agriculture, as a first step, remained unsuccessful. The provision of clothes therefore remained the domain of the French outposts.

On the other hand, the French missionaries did not force Amerindians to dress in 'Christian' clothing. Despite the subarctic climate of New France, native clothes normally covered only minimal body parts even outdoors. ${ }^{58}$ Yet the missionaries may have overlooked the native clothing custom to let their Amerindian converts continue to be providers of furs. Simple clothes made of animal skins had their advantage in life in the wilderness. Clothing made of cotton or wool would have hindered foraging and hunting in such conditions. ${ }^{59}$ Moreover, because the Amerindians in New France lived in a cold subarctic climate, they had developed their own style of clothing, which was better adapted than French-style clothes, which would have been useless outside in the frozen winter of the Saint Lawrence region.

In one way, the attitude of the priests in New France was similar to the missionaries' attitudes in Japan and Paraguay. The missionaries in Japan accepted traditional Japanese fashion as clothes that would maintain Christian decency and moral propriety. In Paraguay, the Jesuits managed to clothe the naked indigenous people by introducing cotton and food farming as well as weaving to them. Nevertheless, the failure in introducing a sedentary life to indigenous Christians in New France prevented the Amerindian development of cloth manufacturing or even of sufficient agriculture. Thus, the French missionaries in the réductions had to clothe Amerindian converts only with as many European clothes as philanthropy and trade could afford. Most of the native settlers continued dressing in furs and skins.

The fifth area of comparison among Japan, Paraguay and New France deals with the success of the priests in creating a completely sedentary community of native Christians, who settled down in houses. In Japan, people were already sedentary and the missionaries did not have to

58 According to Samuel de Champlain, even native women were not ashamed to expose their bodies from the waist up and from mid-thigh down. See H. P. Biggar (ed.), The Works of Samuel de Champlain (6 vols., Toronto: The Champlain Society, 192-36), vol. 3, 133-34.

${ }_{59}$ For example, in 1639 a canoe overturned on its way from Quebec. The canoe contained a Huron lad dressed in a French manner and an Algonquin lad dressed in an indigenous manner, in a simple pelt robe. The Huron man drowned while the Algonquin man was able to save himself by throwing off his robe and swimming to safety. See Le Jeune's Relation of 1639, in Relations 16: 177-79. 
provide houses for their converts. In Paraguay, native large huts were completely replaced by block housing units to transform Amerindians to sedentary agriculturalists just like the Japanese people.

The French attempts, however, ended in failure. Because indigenous hunters and gatherers were not transformed into sedentary farmers in the Canadian réductions, dwellings for permanent settlements were not required. In the native Christian settlements, Frenchstyle buildings only partially replaced Algonquian bark wigwams and Iroquoian longhouses. Despite the assistance of nuns, the introduction of houses in the réductions was limited to the realm of Christian charity. Houses were built either to accommodate principal native settlers or to provide shelter for destitute or homeless people. In 1642, when three hundred native inhabitants lived in Sillery, the réduction had only four little houses and a hospital based on French plans. The two houses for the Innu were built on the Jesuits' side of the settlement while the other two for the Algonquin were on the Hospital nuns' side, separated from the Jesuits' side by an eighteen-metre-wide mound. The principal native residents were lodged in the houses, but many others lived in their own style of dwellings, which the missionaries called 'cabanes'. ${ }^{60}$

In a way, the French Jesuits' tolerance of the Amerindian dwelling custom was similar to the Iberian Jesuits' acceptance of traditional buildings in Hizen. Yet, at the same time, this similarity implies a fundamental difference because the reasons for such tolerance varied in the two regions. In Japan, the Jesuits praised Japanese houses as part of Asian civilisation, and declared them to be compatible with Christianity. In New France, because the réductions were far from selfsustaining and thus had to rely on religious charity, there was little extra money for the mission to accommodate all dwellers in houses. Moreover, because the missionaries did not transform the native people into French-style parishioners living in houses, the missionaries kept these Amerindians as suppliers of furs. Therefore, they were allowed to continue Amerindian hunting, while at the same time, they used temporary shelters located in the settlement. Only those activities, such as Amerindian healing rituals, polygamy, cannibalism, naked dances and indigenous charms that were in violation of Christian preaching,

${ }^{60}$ Vimont's Relation of 1642-43, in Relations 23: 303-07. 
were expressly prohibited. ${ }^{61}$ Since hunting did not offend Christian principles, it was allowed.

Sixth, as for the administration of réductions, the Jesuit missionaries followed the Paraguayan convention in completely controlling the entire population, in the same way as the evangelists in both Paraguay and Japan had previously shared the same administrative principle. While making use of the existing non-European government, the Jesuits in both New France and Paraguay complemented it with their own government in order to gain effective ecclesiastical control of local communities. In the reducciónes, the priests introduced a Spanish style of administration between the level of their ecclesiastical rule and that of the caciques' existing control of people. In the Canadian réductions, the Jesuits maintained the chiefs' authority and seem to have created a ruling system over it.

Although the Jesuit reports speak insufficiently about the administration of the respective réductions, there is a reference that hints at the Jesuits' attempt at complementing Amerindian self-government in Sillery. According to Father Le Jeune in his Relation of 1640, the major reserve residents were urged to set up leaders apart from the civil chiefs of each tribal group. Governor Charles Huault de Montmagny advised the Amerindians to elect chiefs to govern the whole reserve. Accordingly the missionaries helped prominent residents to elect three 'magistrats' on a one-year basis through secret votes. The missionaries agreed that Etinechkawat should continue as hereditary Innu chief. Of these new three commanders, one became chief of prayers and the other two were in charge of keeping the young inhabitants focussed on their religious duties. The four 'magistrats' assumed responsibility for deciding the affairs of the réduction. ${ }^{62}$

At the time of this election, Sillery was developing as a multi-tribal community divided into two major parties, the Innu and the Algonquin. Within these major groups, furthermore, there were segments like the Innu near Quebec, the Innu from Tadoussac, and the Kichesipiirini, or the Algonquin, of Allumette Island. ${ }^{63}$ The réduction administration

${ }^{61}$ For the Amerindian customs with which the Jesuits disagreed, see J. Lalemant's Relations of the Hurons of 1640 and 1643, in Relations 19: 201-203; 27: 39-41; Le Jeune's Relation of 1640-41, in Relations 20: 215-217; and Vimont's Relation of 1642, in Relations 22: 67-69.

${ }^{62}$ Le Jeune's Relation of 1640, in Relations 18: 101-03.

${ }^{63}$ For the Innu residents from Tadoussac, see Le Jeune's Relation of 1639, in Relations 16: 141-43. For an example of a contemporary Huron visitor, see Le Jeune's Relation of 
was beyond the control of a single headman from one of the respective groups or segments. In order to create an efficient administration of this multi-tribal community, the missionaries had to introduce to Sillery an advanced level of self-government beyond tribal chiefdom.

In these attempts at controlling Christian communities also, there was continuity in methodology. The Amerindian réduction government was connected with the ecclesiastical rule of Hizen. The Paraguayan missions were similar to the earlier Japanese ones as far as the administrative arrangements for the reducciónes were concerned. In the same way, the New France missions were comparable to the preceding Paraguayan ones in the developmental sequence of Jesuit methodology for consolidating the priests' control of non-European communities.

Seventh, on the subject of native participation in the mission's management, the Laurentian reserves seem to have been more influenced by a Japanese convention than by the Paraguayan reducciones. The priests initially sought help from their lay French domestics, whom they called 'donnés' from 1639 onwards. ${ }^{64}$ Only later did they introduce Amerindian assistants, whom they called 'dogiques'. Significantly the French Jesuits used the Japanese rather than Paraguayan term. While native Paraguayan assistants were introduced as catequistas when the reducciónes were established, the native Laurentian associates were called dogiques, a word about whose origin the French Jesuits wrote nothing in their accounts. ${ }^{65}$

Because the Jesuits in Paraguay persisted in using the term 'catequistas' instead of any other term for referring to the equivalents for dogiques in their annual reports, the origin of the dogiques is unlikely to be in Paraguay. The French term 'dogique' came from the Latin term 'dogicus'. This Latin appellation was apparently translated from 'dogicos' or 'dojiqus', an Iberian term used by the missionaries in Japan. These last variations were how Iberian priests spelt the original Buddhist word 'dôjuku'. ${ }^{66}$ To put all these in diachronic order, the Iberian

1639, in Relations 17: 137-39. For the Kichesipiirini and main Innu groups, see Le Jeune's Relation of 1640, in Relations 18: 91-97.

${ }^{64}$ J. Lalemant, 'Mémoire touchant les Domestiques', in Relations 21: 293-301; and General Superior Mutius Vitelleschi to Provincial Étienne Binet at Paris, from Rome, 29 March 1639, in Campeau, Monumenta, 4: 203-04.

${ }^{65} \mathrm{~J}$. Lalemant's Relation of the Hurons of 1643, in Relations 27: 67-69.

${ }^{66}$ One should not look for the similarities, of spelling and pronunciation, between 'dôjuku' and 'dogicos' or 'dojiqus'. This alphabetical spelling of 'dôjuku' did not exist 
Jesuits borrowed the office of dôjuku and its Japanese Buddhist expression for recruiting their lay assistants. The term 'dogicos' or 'dojiqus', a name for these lay subordinates, is highly likely to have been adopted by the European Jesuits in Rome and elsewhere through missionary reports. And yet the missionaries in Paraguay did not use this term. It was instead used later by the French priests in New France. ${ }^{67}$ More importantly as opposed to the popular theory of réduction models, the instalment of dogiques in the reductions of New France was not modelled on the reducción system in Paraguay and instead originated in the Iberian Jesuits' emulation of Buddhist assistantship in Japan.

When the French Jesuits began to mention the office of dogique, it was initially not applied to indigenous Christians specifically and became so only later. The first reference to the office of dogique was in Superior Le Jeune's Latin letter to Father Étienne Binet, Provincial of France, in 1638. Father Le Jeune wrote that he should like Dominique Scot, one of the former French domestics in Huronia, to return to New France on completion of his two-year novitiate so that the father might have him work as both a companion and 'dogicus, sive catechista', namely a dogique, or a catechist. However, this position of dogique had become solely the domain of native converts by the time that it was first referred to in the Relations in 1643. According to Father Jérôme Lalemant, the author of the Huron Relation of 1643, older native Christians did the evangelistic work as dogiques on behalf of the

before the twentieth century because it is a modern spelling based on the latest rules for alphabetising Japanese characters. The alphabetical 'dogicos' and 'dojiqus' remained the only spelt forms available in the sixteenth and seventeenth centuries.

${ }^{67} \mathrm{~A}$ full discussion of the international development of the dogique scheme is impossible here because it involves too many aspects to explore within a few paragraphs. Lucien Campeau, SJ, was probably the first to touch upon the origin of dogiques. In one of his notes to Monumenta Novae Franciae, however, Campeau introduced the ambiguous spelling 'dojiku' as the original Japanese term to the French-language reader. And yet 'dojiku' would only indirectly lead to the original Japanese word. Although an accurate alphabetical transcription of this Japanese word may have been difficult in the sixteenth century, he should have spelt it either 'dogicos' in Portuguese or 'dôjuku' in modern alphabetical Japanese spelling, as did Josef Franz Schütte, SJ, in his Valignanos Missionsgrundsätze für Japan (2 parts, Roma: Edizioni de Storia E Letteratura, Via Lancellotti 18, 1951-58), pt. 1, 340; pt. 2, 39-41. See also Campeau, Monumenta, 4: 66, note 2. For the references in English-language articles, see Takao Abé, 'A Japanese Perspective on the Jesuits in New France', Actes du vingtième colloque de la société d'histoire coloniale française, Cleveland, Ohio, May 1994 (Ontario: Mothersill Printing, 1996), 14-26; and Takao Abé, 'What Determined the Content of Missionary Reports? The Jesuit Relations Compared with the Iberian Jesuit Accounts', French Colonial History 3 (2002): 69-82. 
missionaries and in their absence. In 1646, the Jesuits finally mentioned the actual name of a dogique: Étienne Totiri, a Huron convert in the village of Teanaostaiaé. ${ }^{68}$

The first references to dogiques connected with réductions were even later, in 1650. In the Relation of that year, Father Paul Ragueneau wrote about Monique, a blind woman, apparently an Algonquin, who was educated by the Hospital nuns in Quebec. According to Father Ragueneau, when she was captured by an Iroquois party and taken to their country, she served as the mission dogique among the Algonquin captives there. In another chapter, Father Ragueneau added that a native male dogique was playing a valuable evangelistic rôle on behalf of the priests at the Innu mission in Tadoussac, which he called a 'réduction'. ${ }^{69}$

The dogiques' duty was similar to that of the Japanese dôjuku except for the maintenance of the church buildings. During the absence of priests, the Amerindian dogiques offered public prayers and held divine service during warfare and hunting. These dogiques instructed people using their native tongues and baptised any convert who seemed on the point of death. In addition, these dogiques sang the canticles to congregations, and preached Christian law to foreign tribes on behalf of the priests. ${ }^{70}$

The introduction of the office of dogiques not only had older Christian origins but it also seems to explain something about the attitude of the European missionaries concerning the acceptance of non-Europeans into the priesthood, as has been mentioned in the analysis of the Japanese dôjuku and the Paraguayan catequistas. It is highly likely that the French Jesuits emulated the offices of the junior clerics and lay assistants attached to Christian parishes in Europe when they introduced dogiques. Yet the difference in the name of office has an important

${ }^{68}$ Le Jeune, superior, to Étienne Binet, provincial at Paris, from Quebec, 31 August 1638, in Campeau, Monumenta, 4: 65-67; J. Lalemant's Relation of the Hurons of 1643, in Relations 27: 67-69; Ragueneau' Relation of the Hurons of 1645-46, in Relations 29: 275-77; and Ragueneau's Relation of 1649-50, in Relations 35: 247-49. As for Dominique Scot, see Jean Côté, The Donnés in Huronia (n.p.: William Lonc, 2001), 75-85. For Étienne Totiri, see also Charles Garnier's letter to Henry de Saint-Joseph, at Paris, from the country of the Hurons, 7 June 1645, in Campeau, Monumenta, 6: 260-64, esp. 262-63; and Garnier to Saint-Joseph, from [the village of] Saint-Joseph among the Hurons, 14 May 1646, in ibid., 6: 472-76, esp. 475-76.

${ }^{69}$ Ragueneau's Relation of 1649-50, in Relations 35: 247-49 \& 267-77.

${ }^{70}$ J. Lalemant's Relation of the Hurons of 1643, in Relations 27: 67-69; and Ragueneau's Relation of 1649-50, in Relations 35: 277 
connotation. By using these names for non-European offices that were different from European ones, the non-European assistants were excluded from the holy orders of the Church and were also excluded from religious orders. This meant that they were given few opportunities to become priests, or regular members of the Society, in the seventeenth century.

Eighth, the responses of the priests to diseases and the care of the ill had not changed ever since the evangelistic decades in Japan. The French missionaries failed to learn from their predecessors in the Paraguayan mission that their native converts could be killed by imported epidemics. That was inevitable because the missionary correspondents from Paraguay failed to clarify, for their readers in Europe and North America, the connection between the epidemics among Amerindians and the arrival of Europeans. Furthermore, unlike the accidental segregations from foreign diseases in Paraguay, the French priests did not restrict contact between the Amerindians and the French settlers. The missionaries, who were ignorant of bacterial and viral infection, did nothing to prevent the spread of epidemics. They only visited and cared for their native patients. Yet this care was one of the basic acts of Christian charity, and was neither a creative idea of the French priests nor an emulation of the missionaries' care of the ill in Paraguay and Japan.

The Jesuit Relations suggest that the priests had enough opportunities to realise that the Amerindians were suffering from diseases imported from Europe, such as fevers and smallpox. According to Jesuit reporters like Fathers Pierre Biard, Le Jeune and Lalemant, the missionaries were aware that the native population was dwindling ever since the onset of contact with the French. In 1638, the Jesuits even had to abandon their first missionary centre in the Huron village of Ihonatiria, where diseases killed or dispersed the majority of population. In other passages, some boys and girls taken to Quebec or to France in the 1630s were reported to have died of illness. At the same time, note the Relations, the incidence of disease among priests and French settlers was less frequent than among of Amerindians. ${ }^{71}$

${ }^{71}$ On the effect of diseases, see Pierre Biard's Relation of 1616, in Relations 3: 105; Le Jeune's Relations of 1637 and 1638, in Relations 11:193; 14: 217; Le Mercier's Relation of the Hurons of 1637, in Relations 15: 141; J. Lalemant's Relation of the Hurons of 1639, in Relations 17: 59, 115; J. Lalemant's Relation of 164-48, in Relations 33:19. On infants, see Le Jeune's Relations of 1635 and 1637, in Relations 7: 287-89; 11: 97-105; 
The French Jesuit correspondents, however, neither admitted that the native people were dying of European-derived diseases nor saw any need to segregate the healthy from the sick. Only elsewhere did the missionaries seek explanations for the cause of diseases. Christian fatalism, of course, ascribed fatal diseases to the will of God, whenever the source of illness was unknown. The missionaries also developed other explanations. Early on, Father Biard blamed these maladies on intemperance, indolence and the harshness of the wilderness. As for the Innu near Quebec in the 1630s, Father Le Jeune attributed their illness and subsequent deaths to excessive consumption of liquor and poor hygiene. To solve these health problems, he attempted to curtail the liquor trade. At the root of most illnesses, however, was the priests' ignorance of the fundamental difference of vulnerability to disease between Amerindians and Europeans. ${ }^{72}$

These misinterpretations of the causes directed the priests' efforts almost solely towards not prevention of illness but care of the diseased. When Father Le Jeune encamped among the Innu in the winter of 1632-1633, he visited and treated invalid children as though he were a physician. Along similar lines, in Sillery and Trois-Rivières, the missionaries visited diseased residents and baptised especially those presumed to be dying. After the Jesuits introduced a hospital to the reduction of Sillery, the Hospital nuns helped them to care for native patients of different groups. Father Ragueneau even boasted that the nuns' care of sick Amerindians reduced mortality extensively though his only proof for this statement was the frequent philanthropic effort of the priests to care for diseased people in Huronia. The missionaries there visited and cared for every single person suffering from ailments that they could recognise and therefore cure. ${ }^{73}$ Ironically the missionaries' round of visits to invalids disseminated new germs and viruses.

12: 47-51. And on symptoms, see Le Jeune's Relation of 1636, in Relations 9: 139-41; Le Mercier's Relation of the Hurons of 1637, in Relations 13: 109-11 \& 163-65; and Vimont's Relation of 1642-43, in Relations 24: 159-61.

72 Biard's Relation of 1616, in Relations 3: 107-09; and Le Jeune's Relations of 1634 and 1637, in Relations 6: 251-53; 11: 195-99.

${ }_{73}$ Le Jeune's Relations of 1633, 1639, and 1640-41, in Relations 5: 227-39; 16: 217-19; 20: 281-85; Vimont's Relations of 1642 and 1642-43, in Relations 22: 93-113, 155-77; 24: 159-61; Brébeuf's Relation of the Hurons of 1635, in Relations 8: 131-33; J. Lalemant's Relation of the Hurons of 1639, in Relations 16: 243-45; 17: 27-31; and Ragueneau's Relation of 1649-50, in Relations 35: 97; 
Few missionaries, in fact, segregated healthy Amerindians from the sick. They failed to understand that the French settlers carried diseases, and thus they did not segregate healthy settlers from sick native people. Also, there was almost no quarantine of diseased Amerindians. One such exception occurred when four native families came to settle in Sillery in 1638 or 1639. Father Le Jeune refused them entry into the réduction because he did not want them to contract smallpox from the native residents. No other missionaries followed suit in similar situations. ${ }^{74}$

The priests in New France followed the example of the missionaries in Japan. They treated Amerindian patients as if they, like the Japanese, were immune to European diseases. This was partly because of the limitation of medical knowledge in the seventeenth century. The first vaccine for smallpox was invented only at the end of the eighteenth century. It was only later, in the nineteenth century, that humans understood the concept of bacteria as the cause of diseases. Research on viruses developed only from the end of the nineteenth century. And yet flawed medical information does not fully account for the missionaries' conduct as potential carriers, since they were well aware that the diseases they encountered among Amerindians after contact were contagious or infectious. One important reason why the missionaries did not think to segregate settlers and fur traders from indigenous people was the connection between trade and evangelisation. Social contact was necessary for both trade and religious conversion. Furthermore, disease did have a positive side for the missionaries, for it brought out their philanthropic spirit, which became an important component of the Christian mission.

\section{The International Evolution of Missionary Réductions}

Considered in a world-wide context, the réductions in New France can now be interpreted in a different light. First, the idea for Paraguayan reducciónes was based on the Jesuit experiment in Japan. A comparison of the missionary region of Japan with Paraguay and New France raises a further hypothesis on the methodological foundation of the réductions. The major precedents for Laurentian réductions can be

\footnotetext{
${ }^{74}$ Le Jeune's Relation of 1639, in Relations 16: 101-03.
} 
traced as far back as the experimental enterprises for the Christian communities in Japan even though the fundamental Christian activity and custom may have originated even earlier in the European Church. Second, although the réductions clearly emulated the reducciónes in Paraguay, this emulation was not as simple as heretofore claimed. In some aspects, the Canadian models were based on Paraguayan ones, which had been formerly based on the Japanese prototypes. In other aspects, however, the Jesuit scheme in the réductions was based on evangelistic models, such as those for Hizen villages in Japan, rather than on those for the Paraguayan settlements.

From several perspectives, it is true that the Laurentian réductions emulated aspects of the Paraguayan reducciónes. More or less as in Paraguay, the Jesuits established their political autonomy in the réductions while native self-government continued simultaneously in the settlements even under the priests' paternalism. Even closer to the model of Paraguay was Jesuit autonomy in the Huron villages though these villages were not actually called réductions. In spite of its limited success, the Jesuits' effort to settle the Innu and Algonquin peoples in the réductions shared the same ideals with their predecessors in Paraguay. In terms of local administration of the settlements, the priests completed missionary control of the whole residential population by following the Paraguayan convention. Also, the ignorance of the means of prevention of epidemic diseases were the same as those of the missions in the reducciones though the philanthropic care for invalids was a fundamental Christian duty. Nevertheless, one should recognise that all these approaches to the Amerindians were not Paraguayan creations, but emulations of the Iberian mission of the previous century in Japan.

In several ways, the methodology for the indigenous réductions in New France was even closer to that for the Christian communities in Japan, though there were both differences and similarities. For example, there was a fundamental difference behind one particular superficial similarity. Even though the missionaries introduced a great deal of house construction, as well as methods to produce cotton in Paraguay, the priests in New France and in Japan were willing to allow converts to continue living in indigenous dwellings and to dress in traditional non-European clothing. While the attitudes were similar in New France and Japan, the reasons for such cultural tolerance of houses and clothing differed. In this particular respect, therefore, the 
French priests' tolerance in New France was not an emulation of the Iberian priests' tolerance in Japan.

Yet there were also similarities between the missions in Japan and New France. The réductions were not as segregated as the reducciónes from European settlements. The Laurentian reserves were similar to the Christian villages that surrounded the international port of Nagasaki in terms of their distance from European outposts. Also, from the standpoint of native contributions to management, the French Jesuits are highly likely to have imported the office of dogiques indirectly from the Iberian predecessors in Japan, for the same duty as that of the Japanese dôjuku.

As such, it is only half true to claim that Jesuit réductions in New France were modelled on the reducciónes in Paraguay. The methodological development from the Paraguayan experiments to the colonial French attempts can be traced further back to the establishment of Japanese Christian communities. Furthermore, other French missionary approaches to the réductions that were obviously alien to the Paraguayan methods were not creations by the French Jesuits; instead they are more likely to have been inspired in part by, or borrowed directly from, the pioneer missionary approaches in Japan. Thus, most of the fundamental characteristics of the Laurentian réduction scheme can be traced, directly or indirectly, to the prototypical model provided in the creation of the Japanese Christian villages.

Although there may be a counter opinion that the basic EuroChristian elements, like the various acts of charity and the institutional arrangements of the Church, had existed as religious origins in Europe long before the mission in Japan started, such a criticism is off the point. It may even blind one to viewing the delicate aspects of the international development of the whole Jesuit mission beyond a single missionary region. Japan was one of the earliest Jesuit missions outside Europe on which the priests experimented with the introduction of European Church customs. This current study has not intended to seek, in a commonplace way, for the fundamental Christian origins in the ancient Biblical or Greco-Roman world. Instead, it has been concerned with such a prototype as the Japanese church, or one of the first realisations of a Christian community beyond the border of mediaeval Christendom. 
Takao Abé - 978-90-04-20965-7 Downloaded from Brill.comఠ4/26/2023 02:17:13PM via free access 


\section{ACCEPTING AND COMPREHENDING CHRISTIANITY: NON-EUROPEAN PRACTICE OF THE RELIGION}

In both Japan and New France, those whom the Jesuits would convert to Christianity interpreted Christianity and its practice in widely varying ways. What did the Jesuit preaching and Christianity mean to them in the context of their own native culture? What played the most influential rôle in formulating the actual practice of Christianity among converts? Above all, was there any divergence, between the European opinions and the non-European ideas, regarding the true meaning of becoming a Christian in a non-Christian realm? To answer these questions, some hypotheses can be explored about the practice of Christianity among Japanese converts. Such hypothetical perspectives will then be tested in examples of the Amerindian acceptance of the religion in New France.

\section{A. Problems of Historical Epistemology}

Traditionally histories of both regions have focussed on degrees of conversion into what is thought to be authentic Christianity. These historiographical debates are based on the premise that a person is either a true Christian or not, and that a non-Christian who does not completely accept Christian theology can never be called Christian. For example, Christal Whelan examines Japanese rituals and icons, and concludes that Japanese Christians were not at all genuinely converted. Referring to the converts in the missionary settlement of Caughnawaga, near Montreal, David Blanchard contends that Iroquoian neophytes interpreted Jesuit preaching within a traditional indigenous framework and thus failed to become true Christians. Notwithstanding different religious contexts, how much one accepts Christian thought and practice is a global subject rather than just a local issue peculiar to non-European converts. Furthermore, neither Whelan nor Blanchard explains that even in the Europe of the sixteenth century, Jesuits were struggling to convert Europeans 
from folk religions, Islam and Judaism to what Jesuits considered ideal Christianity. ${ }^{1}$

The two treatises of Whelan and Blanchard have unintentionally disclosed three problems of historical epistemology on non-European Christianity. First, they have become mired in a psychological interpretation influenced by personal religious understanding and piety, which leads them to inconclusive results. What the Jesuit missionaries themselves were concerned about was their converts' constancy of faith and of their support for priests, not the degree of resemblance to the European Christian belief. ${ }^{2}$ What seems of greater import to a discussion of nonEuropean Christianity should be how potential converts used their limited understanding of Christianity, based inevitably on non-Christian concepts, in order to grasp and practise this foreign spirituality so that it might serve their needs.

The second problem is how to judge the authenticity of conversion to Christianity on the part of non-Christians. Testing an individual's depth of belief, as both Whelan and Blanchard do, is a typical late-modern attitude, which developed gradually with the spread of Protestantism and its emphasis upon a personal relationship with God. Literate, educated urban residents in sixteenth- and seventeenth-century France favoured Protestantism. Previous to the Protestant Reformation, Christianity was ritual-based collectivism and not testament-based individualism. What the Jesuits fought against in France and the Iberian Peninsula, which were mostly rural, was not so much the rise of Protestantism, and along with it Calvinism, but religious ignorance and folk religion. The missionaries basically controlled the collective practice of Christianity inside the church and at church-sponsored activities such as philanthropy and education, even though converts may still have exercised personal options while outside the jurisdiction of the church and the missionaries. It is therefore inappropriate to use the standards of Protestantism in judging

${ }^{1}$ Christal Whelan, 'Loss of the Signified among the Kakure Kirishitan', Japanese Religions 19 (1994): 82-103; also, cited in Stephen Turnbull, The Kakure Kirishitan of Japan (Richmond, Surrey, UK: Japan Library, 1998), 10-11; and David S. Blanchard, '.. To the Other Side of the Sky: Catholicism at Kahnawake, 1667-1700', Anthropologica 24 (1982): 77-102.

${ }_{2}$ For a typical Jesuit attitude towards the faith of converts, see Reuben Gold Thwaites et al. (eds.), The Jesuit Relations and Allied Documents (73 vols., Cleveland, OH: Burrows Brothers, 1896-1901), vol. 16, 173; vol. 22, 43-45 [Relations 16: 173; 22: 43-45, henceforth]; and Matsuda Kiichi et al. (eds.), Jûroku shichi seiki Iezusukai Nippon hôkokushû (3rd ser, Kyoto: Dôhô-sha, 1987-2000), vol. 4, 44-45 [henceforth, Hôkokushû 3, 4: 44-45]. 
the authenticity of each personal conversion to Catholicism. What is culturally more significant is to assess how Jesuit Christianity was accepted and comprehended collectively by the population with a non-Christian spiritual background. ${ }^{3}$

The third epistemological issue is how to identify a 'typical' Christian in regions that were once non-Christian. When referring to religious Mohawks, Blanchard mainly means Kateri Tekakwitha, a model female convert, well educated by the nuns at Montreal, rather than numerous unnamed residents in Caughnawaga. Even though Tekakwitha was a convert, Blanchard asserts that her Christian fervour was based on an Iroquois religion based on the 'Sky World', the Iroquoian spiritual world beyond the earth. ${ }^{4} \mathrm{He}$ concludes that the other less Christianised Mohawks must have practised a synchretic system of rituals that were nevertheless compatible with Catholicism.

Along similar lines, in Japan, by dealing with a few late-twentiethcentury successors to local Gotô rituals that can at best be described as a kind of Christianity set within a Japanese framework of Buddhism and Shintô, Whelan retrospectively affirms that their ancestors were never converted to the authentic Christian religion. She does not seem to consider two vital facts. One is that the Goto community on which she focuses was established during the last years of the eighteenth century by the descendants of three thousand immigrants from the Ômura domain, most of whom were descendants of Christian converts. The other is that, due to continual proscriptions, Christianity as established by Jesuits in the islands had been extinct for no less than two centuries when this immigration of Ômura refugees occurred after 1797.

Thus, neither Kateri Tekakwitha nor the ancestors of the Gotô were what can be represented as typical Christian converts. Their religious practices, therefore, should not be considered typically Christian in any way. When discussing Amerindian or Japanese practice, one should give priority to a majority of residents under missionary instruction rather than focusing specifically on the minority of proselytes with special

\footnotetext{
${ }^{3}$ For modern religious individualism, read Alan Neal Galpern, The Religions of the People in Sixteenth-Century Champagne (Cambridge, Mass.: Harvard University Press, 1976). For popular religion in Western Europe, see William A. Christian, Local Religion in Sixteenth-Century Spain (Princeton, N. J.: Princeton University Press, 1981); and A. Lynn Martin, The Jesuit Mind, esp. 226-227.

${ }^{4}$ Blanchard, op. cit., 79-84. For the detailed description of the Iroquois Christian community of Caughnagawa, see Allan Greer, Mohawk Saint: Catherine Tekakwitha and the Jesuits (New York: Oxford University Press, 2005), 89-110.
} 
Christian education or on post-missionary communities that developed without priestly guidance.

More debatable idea can be found in Nicholas P. Cushner's theoretical premise that the non-Christian peoples had their own religions, or belief systems, that are replaceable with Christianity. This simplistic premise has enabled Cushner to conclude that Amerindian 'religions' were replaced by Christianity albeit incompletely. ${ }^{5}$ As the second chapter has indicated, however, what the Jesuits perceived to be an indigenous religion was their own arbitrary combination of various spiritual and unspiritual customs. He therefore needs to prove, in the first place, his basic premise that indigenous Americans had established a set of a belief system fully compatible with Christianity.

Keeping in mind the incorporation of the Christian belief, the authenticity of conversion and the identification of a typical Christian, this case study of Japan will replace existing context-based discussions with perspectives empirically based on Japanese precedents. This analysis will be tripartite. First, the Jesuit descriptions of model converts provide an insight into the criteria used by Europeans to identify Christian converts. Second, incidental observations by missionaries, often more casual than deliberate, hint at the neophytes' unique ethnic understanding of Christianity. Third, the Japanese case presents typical obstacles, in cross-cultural comprehension of the faith, that can be applied to the consideration of the Amerindian experience.

\section{B. Japanese Acceptance and Comprehension of Christianity}

The discussion of the Japanese acceptance and comprehension of Christianity will initially confirm three basic tenets. First, unlike the monotheistic and exclusive tradition of the Christian faith in God, conventional Japanese spirituality was basically polytheistic and harmoniously coexistent, as the second chapter has indicated. Second, owing to the limitations of language and culture, as stated in the third chapter, the priests tailored their approaches to suit the Japanese. Finally, as the third chapter has also described, Jesuit activity comprised, not only preaching but also education, philanthropy and elementary medical care.

${ }^{5}$ Nicholas P. Cushner, Why Have You Come Here? (New York: Oxford University Press, 2006), 3-4, 149-69 \& 197. 
Jesuit rhetoric, however, obscures the extent of the Japanese acceptance of Christianity simply by emphasising the good deeds of model converts. In the missionary accounts, model Christians were faithful followers of Jesuit preaching. These converts respected priests. They attended Mass, prayed regularly and made confessions. They assisted missionaries in persuading others to join the faith. For example, Father Gaspar Vilela praised the converts in Nagasaki in 1571. He gave three reasons. First, their local landowner constructed a church building for the Jesuits. The converts destroyed Buddhist and Shintô constructions in the name of God. They regularly attended Mass and sermons and did penance for their sins. ${ }^{6}$

In the annual report of 1581 also, Father Gaspar Coelho applauded the religious fervour among the converts in Kyoto. According to him, they were willing to follow Christian doctrine and to use Christian icons and rosaries at sacraments. They would gather around Father Alessandro Valignano, travelling distances up to sixty to eighty kilometres, in order to seek spiritual help through the Agnus Dei, sacred icons and rosaries. They also prayed, and in general, they obeyed Jesuit preaching. ${ }^{7}$

However, there is a clear difference of perspective between the priests' appraisals of Christians and their offhand and unintentional references to Japanese responses. For a more accurate understanding of the nonEuropean acceptance of Christianity, one must examine their responses to the missions. To do so, it is necessary to consider the popular image of Jesuit services, including education and philanthropy, based on the order's principles. An ordinary Japanese idea of becoming a Christian was based inevitably on the polytheistic response to this complex missionary service. The converts and future converts developed their own perspectives on the religion of God through their spiritual conventions.

The spiritual climate of Japan, which allowed the Japanese to accommodate and incorporate Jesuit preaching, was basically flexible and absorbent, unless that infrastructure found itself under theological attack. Theologian Neil Fujita compares Christianity and Japanese spirituality to a cone and a doughnut. ${ }^{8}$ Japanese society has always been tolerant

\footnotetext{
${ }^{6}$ Gaspar Vilela to the companions in Portugal, from Cochin, 4th February 1571, in Matsuda, Hôkokushî 3, 4: 44-45.

7 Gaspar Coelho, the annual report of 1581 to the general superior, from Nagasaki, 15 February 1582, in Matsuda, Hôkokush û 3, 6: 38-39.

${ }^{8}$ Neil S. Fujita, "Conic" Christianity and "Donut" Japan', Missiology: An International Review 22 (1994): 43-53.
} 
towards foreign philosophies, including Buddhism, which was introduced gradually in the sixth and later centuries. In a centreless thought structure, numerous spiritualities coexist amicably without being dominated by any one of them in the centre. In Christianity, a single absolute God resides at the centre, or at the summit, and has created and ruled the entire world in His conic structure. When this conic structure was imposed on Japanese thought, Fujita contends, Christianity was rejected. Although this image is plausible from an ideological perspective, it is not fully applicable to the minds of the ordinary people.

Within their centreless spiritual custom based on a receptive tolerance, the ordinary residents accepted Christianity. Father Luis Frois's annual report of 1585 symbolically describes this custom of Japanese society. In that year, as many as thirty-six years after the mission opened in Bungo, the proselytes in the town of Funai installed a large crucifix on the site of a future church building. For the lumber, the congregation chose the Shintô-deity wood that had been annually used for a Gion feast, and carried it on a cart through the town centre. As though they were at a Shintô festival, they presented this wood to the public in a parade that featured dancers accompanied by drums, fifes and other musical instruments. Father Frois commented positively on this parade, which he took as a demonstration of the growing influence of Christianity, since he was not fully aware of the connection between Gion and Shintô. He does not seem to have understood that the converts either treated the lumber simply as another deity or considered this foreign religion to be compatible with Shintô. Above all, in the harmony-based Japanese spiritual system, they could not imagine that God would reject a crucifix made of sacred Shintô wood. ${ }^{9}$

It is through the lens of this harmonious spiritual coexistence peculiar to Japan that any attempts to analyse the degree of acceptance of Christianity should be made. To begin with, for pupils and their parents, the Christian schooling meant another version of Buddhist education. In Bungo of the 1560s, for instance, the missionaries intended to attract the boys of Buddhist temples to their Christian school, where Christian teachers taught not only Christian doctrine but also the same reading and writing as were taught in the Buddhist temples. In 1566 in Kuchinotsu, in the domain of Arima, a former Buddhist temple was

${ }^{9}$ Luis Frois, the annual report on the district of Bungo, from Nagasaki, 20 August 1585, in Murakami Naojirô (ed.), Iezusukai Nippon nenpô [Nenpô, henceforth] (1969), 2: 1-36, esp. 4-5. 
converted into a Jesuit schoolhouse, which successfully recruited pupils from other Buddhist schools. This Buddhist aura of Christian education was enhanced by the fact that ex-Buddhists and ex-students at temples were in charge of teaching on behalf of European priests who had less command of Japanese. ${ }^{10}$

Christian neophytes applied a similar Shintô analogy to Christianity. In the minds of local residents, access to Christian philanthropy and a contribution to it were associated with participation in a traditional system of Shintô mutual aid, or in what was called miyaza or $k \hat{o}$, a commonly-used noun that exists today. The miyaza, a lay Shintô group composed of the upper social echelons in a village or town, worked as a social and philanthropic club as early as the tenth or eleventh century, and continued to function through the Meiji era. While its philanthropic work ended after Meiji, its rôle in organising the feasts of local shrines survives today in western Japan. Throughout pre-modern centuries, this Shintô association played a key part in the feast for distributing harvests throughout local communities. The $k \hat{o}$ originated in a special gathering of the eleventh or twelfth century to listen to Buddhist preaching. It developed throughout the country into numerous small sub-village organisations for mutual aid by the time the first Jesuits arrived in Japan. This type of association usually consisted of the secular participants in a local shrine or temple, often socially influential local residents. It provided social and material assistance to impoverished members by means of charities and feasts. ${ }^{11}$ The priests made use of these existing infrastructures in order to disseminate their own philanthropy, and thus to attract more converts from among the ordinary people. More significantly, whether through the old Shintô or through the new Christianity, the actual participants in the poor relief were the same local Japanese neighbours as before, except for the addition of a small number of stationary foreign or domestic missionaries. For both those helping and those being helped,

${ }_{10}$ Juan Fernández to the companions generally, from Bungo, 8 October 1561; Luis d'Almeida to the companions in India, from Yokoseura, 17 November 1563; Belchoir Figueiredo to the companions in India, 13 September 1566; and Luis Frois, the annual report of 1583 to the general superior, 2 January 1584. Murakami Naojirô (ed.), Iezusukaishi Nippon Tsûshin [Tsûshin, hereafter] (1968-69), 1: 237-38, 350-51 \& 358-59; 2: 54-57; Matuda, Hôkoku-shû 3, 6: 175-76.

${ }^{11}$ For the more details of kô, see Yamaguchi Yaichirô, Shûraku no kôsei to kinô (Tokyo: Hakubun-sha, 1976), 53-55; Takeuchi Toshimi, 'Shakai seikatu', in Nihon minzoku shiryô jiten (Tokyo: Daiichi hôki, 1969); and Hukuda Ajio, Nippon sonraku no minzokuteki kôzô (Tokyo: Kôbun-dô, 1982). 
local philanthropy itself implied some means for Shintô activity, and local people seem to have accepted Christianity as an exotic version of Shintô, and missionaries as Shintô conjurers.

As an extension of philanthropy, the elementary medical care of the mission encouraged belief in the healing power of Christianity. The existing shamanist curative traditions, whether carried on by Buddhist monks or by Shintô and folk remedy prayers, also provided the preconditions for the popular acceptance of the healing deity. Because medical service in those centuries was only for those wealthy citizens who could afford it, the Christian mission represented a generous foreign healing spirituality through philanthropic clinics and leprosaria as well as extensive visitations. Those converts who were in poor health and who lived in areas governed by pro-European lords expected cures from European missionaries. ${ }^{12}$ By using medical care as a way of persuading the sick to accept Christianity, the Jesuits only further blurred the differences between Christianity and Eastern spirituality. ${ }^{13}$

Expecting health and cures from the Christian church was also a transformation of the domestic custom of visiting temples and shrines in those centuries when people believed that an infirm soul or a wicked spirit caused the affliction of a body. There was, for example, a belief called ohyakudo mairi or one-hundred-time visitation. If a person prayed at a healing-related shrine one hundred times, he or she would eventually expel disease from his or her own body. Traditionally Japanese shamans, called miko and yamabushi, played a healing rôle by communicating with the spirit that, they claimed, had produced illness. Missionary documents include passages describing the provision of healing services by temples, as exemplified by the following two references. In 1554, Father Pedro d'Alcáçova referred to an unnamed faithless or careless neophyte, who, having recovered from a fever under the Jesuit instruction for Christianity, fell sick again by visiting a temple for additional cures. According to Brother João Bautista in 1564 , there was a growing idea among people that one must come to church rather than Buddhist temples in order to regain one's health. ${ }^{14}$

12 For numerous references to Jesuit medical care, see Murakami, Tsûshin, 1: 50-55, 178-79, 190-91, 200-01, 256-57; 2: 158; and Murakami, Nenpô, 1: 33 \& 66.

13 See, for example, the Jesuit approach to the lord of Gotô in 1566. Frois, Furoisu Nipponshi (1977-80), 3:15-26; Frois, Historia de Japam (1976-83), part 1, chap. 4.

14 Pedro d'Alcáçova to the companions in Portugal, from Goa, 1554, in Murakami, Tsûshin, 43-60, esp. 55-56; Juan Bautista's letter from Funai, 31 December 1564, 
The curing effect of conversion to Christianity developed into a popular belief in the medicinal value of Christian items of faith such as holy water, at least as far as the Japanese pre-modern imagination could conceive of these religious items. There already was a belief in Japan, prior to the arrival of the Jesuits, that water had the power to restore health, as well as the power to bring about natural disasters. The people in the archipelago had conventionally associated water with a number of miracles, including the restoration of health, youth and beauty. At the entrance to every Shintô shrine, a large water fountain allowed worshipers to clean their hands, mouth and other body parts before stepping into its precincts. In front of a Buddhist altar, a tiny cup of fresh water was offered every morning. In addition, the natural power of water in seas and rivers had both positive and negative associations, including creative and destructive powers, and a belief in the water deity. There are even now shrines dedicated to a water deity, connected to a nearby sea, river, pond or lake, throughout the country, especially where residents repeatedly experienced natural disasters and accidents. The Japanese legend also created the kappa, an imaginary water imp, that was believed to live in a pond or a river and to play tricks on humans, and people blamed it for mysterious water-related accidents. Thus, it was only normal that the Japanese associated spirituality with water.

Based on this traditional spiritual infrastructure, people readily accepted the belief in sacred Christian water. Because the Jesuits used sacred water symbolically for all basic cures, this holy water was popular with the Japanese. In Bungo of the 1550s, remote villagers travelled ten to twelve leagues to ask for water at a Jesuit residence. In Sakai and Kyoto in the 1560s, proselytes took sacred water home in their own containers because they expected a healing effect from it. In Bungo in the 1570 s, villagers gathered at church simply to drink some sacred water. ${ }^{15}$ The annual report on the year 1581 states that this fashion

quoted in Frois, Furoisu Nipponshi, 7: 24-31, esp. 30-31, and in Historia, pt. 1, chap. 53.

${ }^{15}$ Pedro d'Alcáçova to the companions in Portugal, from Goa, 1554; Duarte da Silva to the companions in India, from Bungo, 20 September 1555; Luis Frois, from Sakai, 8 July 1567 (No addressee is recorded.); Luis Frois to Belchior de Figueiredo, from Kyoto, 1st June 1569; and Francisco Cabral to the companions in Portugal, from Kuchinotsu, 9 September 1576. Murakami, Tsûshin, 1: 43-60, 77-92, esp. 55 \& 87-89; 2: 297-320, esp. 315-16; Murakami (ed.), Yasokai Nippon tsûshin (2 vols., 1928, Tokyo: Yûshô-dô, 1975), vol. 1, 444-45. 
even induced non-Christians to visit Jesuits in Bungo. The belief in the healing power of water motivated villagers to seek baptism. ${ }^{16}$

The belief in Jesuit sacred water as a medicine developed into more spiritual acts by the congregation. By imitating the gestures of priests, converts attempted to transform plain water into what they alleged to be an effective medicine. They commonly believed that Christian artefacts without a priest would have the same curative effect. A rosary made of Saint Thomas's crucifix is one example. In the late 1560s, Lord Ômura Sumitada, the renowned Christian patron of the Jesuits, told Fathers Cosme de Torres and João Bautista that he had used this rosary to prepare healing water to succour a non-Christian woman suffering from a chill and fever. In the early 1580s, Father Luis Frois referred to this rosary, now owned by someone else, whom he did not name. According to Father Frois, the owner placed it in a bowl of water and then gave the water to sick people. Father Frois also mentioned another unnamed lay Christian who held beads blessed by the Pope. This Christian steeped them in water and crossed himself, expecting them to have a healing effect. ${ }^{17}$

Other secular examples, of belief in the magical power of Christian objects, included rosaries, communion wafers, and even the soil and wood of sacred places and the dust on Christian icons. In the 1570s, a Christian in Kansai swallowed a shaved piece of rosary bead as a replacement for medication. In Bungo of 1555, when members of a congregation were suffering from destitution and disease, converts used sacred water and communion bread to restore their health. On the martyrs' hill of Nagasaki, where twenty-six Christians were publicly executed on the order of the central Toyotomi administration in 1597, local residents later treated the soil and wood at the site as though they were real medicine. In Funai of the early 1580s, a proselyte attempted to heal the fever of his non-Christian neighbour by having him drink a mixture of

16 Gaspar Coelho, the annual report of 1581 to the general superior, 15 February 1582, in Murakami, Nenpô, 1: 31-116, esp. 65-66; and in Matsuda, Hôkokush $\hat{u}, 3$ rd series, 6:01-80, esp. 34-35.

${ }_{17}$ A letter of 15 August 1569 to the Jesuits in Portugal, by an unknown Portuguese addresser whose name record is not extant; and Luis Frois, the annual report on 1582, from Kuchinotsu, 31 October 1582. Murakami, Tûshin, 2: 175-95, esp. 190-91; Murakami, Nenpô, 1: 165-204, esp. 180-81; and Matsuda, Hôkoku-shû, 3rd series, 3: 383; 6: 81-116, esp. 96-97. 
water and dust removed from a Christian drawing that he kept at his house. ${ }^{18}$

It was the symbolic acts of missionaries that often induced converts to accept Christian items for healing. For instance, Father Francisco de Xavier initially promoted belief in the miraculous power of his disciplinary cane and other items. In 1549, Father Xavier preached to the retainers of Niirô Iseno Kami Yasuhisa, a local lord of Ichiku in Satsuma, today's Kagoshima prefecture. When one of them, a convert called Miguel, asked him for a healing tool, the priest granted him the cane. Father Xavier instructed him to tap sick patients five times while chanting the Hail Mary and the name of Jesus Christ so that they might regain health. Miguel extended this form of symbolism, and in order to cure the sick he used the paper on which Xavier wrote down his prayer. Later in 1562, Brother Luis d'Almeida noted that Miguel preserved this paper in his holy treasure bag and hung it around a patient's neck as a curative. As in the case of Ichiku, Father Xavier gave a passage of the Gospel written on sheets of paper to those who asked him for curative remedies on his trip from Hirado to Kyoto. This case of a testament passage card helps to affirm that Miguel's worship of a prayer card was based on Father Xavier's instruction rather than the proselyte's own interpretation. ${ }^{19}$

It is not clear whether Father Xavier's use of cards was in emulation of the indulgences that were used by the mediaeval European church to remit temporal punishment due for sins that have already been forgiven. In any case, the Japanese custom of honouring or treasuring a Shintô or Buddhist talisman facilitated the acceptance of Christian priests' cards or slips. Father Luis Frois's Historia de Japam refers to an example of the use of the drawing of a crucifix on a sheet of paper as an object of worship. In 1559, a fisherman in Ikitsuki received baptism from Father Gaspar Vilela. This convert, whose name was not recorded, put up the cross drawing in his house to pray for the safe delivery of his baby. Although Father Frois did not connect the incident with Japanese

18 Alessandro (or Alexandre) Vallareggio, in India, to the companions in Portugal, 1572, in Matsuda, Hôkokush û 3, 4: 165-78, esp. 177; Balthasar Gago to the companions in India and Portugal, from Hirado, 23 September 1555, in Murakami, Tsûshin, 1: 93-103, esp. 97-98; Léon Pagès, Histoire de martyrs japonais (1862, trans. by Kimura Tarô as Nippon nijûroku seijin junkyô-ki in 1931), 245; Frois, the annual report on 1584, dating 3 September 1584 at Nagasaki, Matsuda, Hôkokushû 3, 6: 245.

${ }_{19}$ Frois, Furoisu Nipponshi, 3: 15-26; 6: 41-49, 261-74; Historia, pt. 1, chaps. 2, 4 \& 32; Luis d'Almeida to the companions generally, from Yokoseura, 25 October 1562, in Murakami, Tsûshin, 1: 265-91, esp. 271-73. 
customs, it was reminiscent of typical Shintô and Buddhist charms. ${ }^{20}$ In another case, Brother D'Almeida and Father Frois described the converts in Shimabara, of the domain of Arima, who used a charm-like sheet with a crucifix on it instead of the name of a temple or a shrine. They posted a sheet at the main entrance to their homes. Although Jesuit annalists praised this act as a demonstration of strong faith, their own references to the incident suggest the converts' misunderstanding of the significance of the cross as well as their confusion about its connection with Shintô or Buddhist talismans. ${ }^{21}$

There was another Jesuit instruction that made converts believe in the remedial effect of crossing oneself. From the outset of the mission, proselytes seem to have been told to cross themselves in order to regain their health. According to Father Pedro d'Alcáçova, a convert in Kyushu was instructed by an unspecified Jesuit Father to cross himself. Accordingly he recovered from poor health. Subsequently this convert visited a temple for complete recovery and fell ill again. The Father once again advised him to make the sign of the cross. The writer concluded that this repeated crossing finally healed the patient. ${ }^{22}$

This type of popular Christian practice sometimes developed beyond Jesuit control. The worship was directed towards ordinary objects in some cases. There were numerous Christians in Nagasaki who believed in the curative power of the metal nails used on the wooden execution poles for the twenty-six martyrs in 1597. In Funai, despite the ensuing disapproval of Jesuits, the proselytes treasured Father Cosme de Torres's hairs and fragments of his clothing after his death in $1570{ }^{23}$

Archaeological discoveries also suggest the worship of Christian objects as charms among Christians, although it is not known whether missionaries were for or against this form of worship. In the former Jesuit-occupied prefectures like Fukuoka, Nagasaki, Kumamoto, Ôita and Osaka, there are numerous remains that were discovered during the late-twentieth century, including cross-inscribed roof tiles, wooden

${ }^{20}$ Frois, Furoisu Nipponshi, 6: 221-25; Historia, pt. 1, chap. 22.

${ }^{21}$ Luis d'Almeida to the companions in India, from Yokoseura, 17 November 1563, in Murakami, Tsûshin, 1: 336-77, esp. 352-53; \& Frois, Furoisu Nipponshi, 9: 62-81, esp. 64-67; Historia, pt. 1, chap. 45.

22 D'Alcáçova to the companions in Portugal, from Goa, 1554, in Murakami, Tsûshin, 1: 43-60, esp. 55-56.

${ }^{23}$ Pagès, op. cit., 245; Frois, Furoisu Nipponshi, 6: 200-07; Frois, Historia, pt. 1, chap. 19. The attempt to treasure Father Torres's relics was not unique to Japanese converts and had a precedent in the Catholic veneration for relics. 


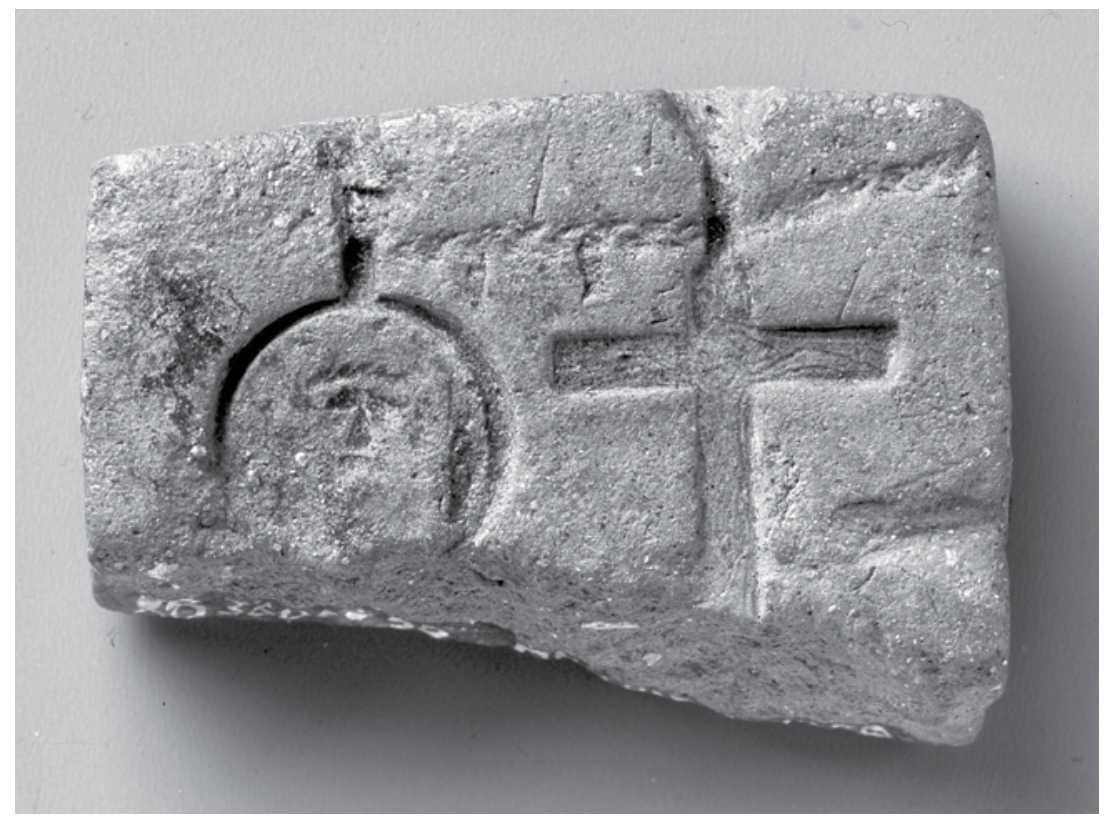

Source: Hakata iseki-gun dai 111-ji shutsudo 'medai jûjika igata', The Fukuoka-city Archaeology Centre

10. Japanese Mould for Medals and Crucifixes in the Late Sixteenth or Early Seventeenth Century: $1.4 \mathrm{~cm} \times 4 \mathrm{~cm} \times 5.5 \mathrm{~cm}, 40$ grams, excavated in Fukuoka in 2002

coffins, ${ }^{24}$ rosaries, medallions, medals, crucifixes and moulds for medals and crucifixes. Of greatest historical interest are crucifixes, medals and their moulds. In the years leading up to 2002, foreign bronze medals and crucifixes, as well as coarse Japanese-made crucifixes, were excavated, but they alone were of little historical value, other than revealing the existence of the Christian church. In March 2002, elaborately manufactured moulds, one for medals and the other for crucifixes, were found in the city of Fukuoka. Yet the moulds alone were insufficient to indicate whether it was priests or converts who were using the cast medals and crucifixes. In December of the same year, however, six Christian medals, made either of lead and tin or of copper alone, were found at Funai in the former domain of Ôtomo. This discovery, together with the previous findings, implied

${ }^{24}$ The Japanese custom of cremation does not leave used coffins behind. 
that converts duplicated and treasured medals for their own purposes, including their use as charms. This also suggests that the locally-made crucifixes were also valued for the same use. The recent archaeological discoveries, combined with the historical documentation, suggest that Japanese Christians believed in the supernatural effects of medals and crucifixes and reproduced them as beneficial charms, in a similar way as other Japanese folk treasured Shintô or Buddhist symbols. ${ }^{25}$

Thus, being a Christian and a member of one of the Japanese congregations during the Jesuit mission involved something beyond existing historical interpretations and beyond the Jesuit rhetoric. It cannot be fully assessed simply by reference to the personal degree of conversion, nor can it merely be denied by reference to the non-Christian remnants in the sacraments and icons to which Whelan makes reference. ${ }^{26}$ When the pervasive destruction of temples and shrines by proJesuit inhabitants under the order of local Christian lords, described in the fourth chapter, is also taken into consideration, it is clear that there were certainly Christian congregations in the archipelago. To understand the Christian identity of Japanese, one needs to examine in detail the sixteenth-century perspectives on self-identification of both Christians and Japanese.

To individual converts in Japan, Jesuit Christianity meant four things. First, Christianity replaced the social ties-especially for mutual help in the case of the Japanese-with which no individual could dispense. Considering, along the same lines, the Christian villages in Hizen that were discussed in the fourth chapter, the Christian religion worked as a social bond that formed a community beyond individual practice. Second, Christianity offered access to worldly benefits by divine grace, as well as to social services, including education and welfare. Third, it was believed that Christianity provided a new healing power that people often thought was analogous to existing spiritualities. Fourth, the new spirituality allowed access to a deity and the benefits associated with him by means of religious objects.

${ }^{25}$ Even though the reproduction of Christian tools may appear to have been associated with the popular religion of mediaeval and early-modern Europe, the Japanese converts were not familiar with it. This Japanese belief in Christian symbols represents the converts' emulation of their popular custom of believing in supernatural powers of Shintô talismans or Buddhist sutras.

${ }^{26}$ Whelan, op. cit., 82-105. 
These aspects of the Japanese version of the faith were results of natural responses to evangelisation rather than the proselytes' reinterpretation of preaching. The missionaries were responsible for borrowing the ready-made systems of education and mutual aid already in existence in Japan. The new system of medical care, even though still rather elementary, was also a generous expansion of the existing healing and shamanistic purifying services available in pre-Jesuit days. The ordinary Japanese folk accepted the Jesuit additions to their spiritual world with no hesitation, and they placed them within the traditional customary frameworks. In other words, they accepted some of the Christian symbolism by placing it within the realm of their native imagination.

The missionary approach, which was revised for use in Japan, was therefore the primary determinant for the acceptance and comprehension of Christianity. The non-Christian cultural infrastructure for the reception of the new religion was of secondary importance. Religious comprehension was determined by Jesuit schemes for converting people, including the Japanese version of preaching, the approaches to central and local daimyô for the collective conversion of their vassals and domain residents, the Society's basic policy of caring for the destitute and the sick and religious education, all of which have been discussed in the previous chapters. The missionaries modified their basic methods according to their understanding of the social and spiritual environment of Japan. Through the limited resources based on this comprehension and on the Jesuits' selective emphasis on specific aspects of missionary services, Japanese Christians developed their own understanding of the religion. Their concept of Christianity was beyond the scope of the rhetorical references to model proselytes in the missionary correspondence. These rules will now be applied to the Amerindian case.

\section{Amerindian Acceptance And Comprehension of Christianity}

In 1642, Father Barthélemy Vimont applauded the neophytes in the Christian réduction of Sillery as model Christians. As proof of their constant faith, he pointed to several examples, such as their eagerness for the frequent reception of the Sacraments, their 'hunger' for God's word, their observance of His commandments, their regular daily attendance at Mass, their voluntary punishment of delinquents, and their zeal for the defence and propagation of the faith. In addition, they prayed to 
God in their dwellings before going out hunting, and thanked Him at the chapel on their return. They observed solemn Christian festivals according to the season. They also refused to participate in a dance or a feast that was thought to be against Christian modesty. ${ }^{27}$ As was the case with Japanese converts, these were the typical observations that the missionaries recorded for presenting their evangelistic achievement in converting the Amerindians to Christianity. ${ }^{28}$

There have been two basic kinds of perspectives about the conversion of native peoples to Christianity in New France. One is that the Jesuits were successful in converting Amerindians to Christian values, an argument stated by James Axtell and Karen Anderson. This perspective is based on an uncritical reading of the Jesuit accounts that are full of the heroic endeavours and missionary achievements of the priests among indigenous converts. By contrast, the second perspective is that the missionaries were unsuccessful in converting the Amerindians. In other words, the conquest and subordination existed only in the rhetorical universe of The Jesuit Relations, and not in the actual communications between missionaries and native peoples, a claim recently postulated by Carole Blackburn. According to this thesis, Amerindian converts subverted the missionaries' intended meaning and the significance of the Christian preaching by using their own cultural logic. ${ }^{29}$

However, neither of these opposing standpoints, premised as they are on the degree of success, draws a true picture of the Amerindian acceptance and comprehension of Christianity. As the missionary case in Japan shows, Christian conversion was a result of the cross-cultural communication between European evangelists and future non-European converts. For an authentic portrait of conversion, one may well consider both the evangelists' adaptive approach and the Amerindians' cultural compatibility to it, under the four categories revealed in the analysis

27 Vimont's Relation of 1642, in Relations 22: 43-45.

28 Two more examples among many include Paul Ragueneau's letter to Mutius Vitelleschi, general superior, at Rome, from Trois-Rivières, 28 July 1641; Jean de Brébeuf's letter to Vitelleschi at Rome, from Québec, 20 August 1641; in Lucien Campeau (ed.), Monumenta Novae Franciae (9 vols., Roma: Instittum Historicum Societatis Iesu; \& Montréal: Bellarmin; or Québec: Les Presses de l'Université Laval, 1967-2003), vol. 5, 20-24 \& 26-29 [Campeau, Monumenta, 5: 20-24 \& 26-29, henceforth], esp. $22 \& 27$.

${ }^{29}$ James Axtell, The Invasion Within (New York: Oxford University Press, 1985), 91-127, 277-80; Karen Anderson, Chain Her by One Foot (New York \& London: Routledge, 1991), 224-29; and Carole Blackburn, Harvest of Souls (Montreal \& Kingston: McGill-Queen's University Press, 2000), 105-139. 
of Japanese converts. These categories include, first, social ties; second, access to social service and to worldly benefits by divine grace; third, curative methods; and fourth, religious talismans.

\section{Christianity as Social Ties}

Just as Christianity took over the Japanese social ties in association with Shintô and Buddhism, it also played a similar rôle in New France. In the Amerindian imagination, baptism was affected by a desire for reunion with deceased relatives in the next world, after death. The native peoples-Innu, Algonquin and Huron-had a traditional belief that one would go to the land of the dead somewhere distant to the west. The Jesuits borrowed this basic idea of spiritual migration after death in preaching about heaven, where God resided, and where native people went after death, if baptised just before death. In 1636, a Huron woman refused baptism when she learnt that her dead nonChristian relatives, who had not been baptised, had therefore not gone to heaven. The same understanding could also work in the opposite way, as evidenced in that same year. Huron parents whose children were baptised at death sought their own baptism from the missionaries, since they did not wish to be separated from their children, who they assumed had gone to heaven. As well, according to Father Vimont in 1642, a healthy native resident in Sillery explained to a missionary that he wanted to be baptised in order to reach the same destination as his dead wife, who had died as a Christian and, he believed, had gone to heaven. ${ }^{30}$

There were two factors that underpinned these ideas. One was that of the Jesuit preaching about heaven. The priests frequently explained to the indigenous people that Christians could go to heaven in the sky after death. According to the missionary preaching about heaven given to converts in Sillery in 1646-47, the sky was used as a synonym

${ }^{30}$ Paul le Jeune's Relations of 1634 and 1637, in Relations 6: 177-79; 11: 101-03; Paul Ragueneau's Relation of 1651-1652, in Relations 38: 23-25; Jean de Brébeuf's Relation of the Hurons of 1636, in Relations 10: 31-33 \& 143-47; François Joseph Le Mercier's Relation of the Hurons of 1637, in Relations 13: 251; \& 14: 109; and Barthélemy Vimont's Relation of 1642, in Relations 22: 109-113. For the Innu and Algonquin land of the dead, see also Alfred Goldsworthy Bailey, The Conflict of European and Eastern Algonkian Cultures, 1504-1700 (1937, 2nd ed., Toronto: University of Toronto Press, 1969), 138-39. For the Huron or general Iroquoian idea of the land of the dead, see also Elizabeth Tooker, The Ethnography of the Huron Indians, 1615-1649 (1964, Syracuse: Syracuse University Press, 1991), 140 \& note 65. 
for heaven. The sky was explained as the beautiful and ravishing place of eternal dwelling that could console Christians. The other factors shaping native views of baptism were the numerous baptisms of those about to die. Throughout the years of the mission in Huronia, the evangelists were normally unsuccessful in persuading healthy Hurons to accept baptism. Instead, they attempted to baptise native people on their deathbeds so that they might die as Christians. This was also often the case with the mission to the Innu and the Algonquin around the French outposts. These two factors together meant to the bereaved that their deceased family and kinship members had gone to the Christian heaven rather than to the traditional land of the dead. ${ }^{31}$

In the réductions near the French settlements, Christianity introduced other social bonds that had been unknown in the Huron mission near distant Lake Simcoe. The interests of both the native residents and the evangelists coincided. When Amerindian parties first moved to Sillery or Trois-Rivières in 1637, they took advantage of material and human resources under Jesuit control, which were incentives to accepting Christianity, in order to re-establish their own communities. The missionaries attempted to control the native réductions by using Christianity as a new social norm that would unite all the native residents as a community. ${ }^{32}$

Yet Christianity was slow to transform itself into a form of social bond in the Amerindian settlements. Even in Sillery, which was more religious than any other contemporary Laurentian réduction, the native residents resisted for nine years before most of the people accepted Christianity and got socially united as a native Christian community. The Jesuits only succeeded in completely converting the residents of Sillery as late as $1646 .^{33}$

There were two reasons for this delay. First of all, births and deaths, along with constant migration, made the task of the missionaries difficult. The location of this Algonquin and Innu settlement was convenient for both those who intended to stay near Quebec temporarily and those who wanted to join the native community permanently. In the Relation of $1642-1643$, for example, Sillery was reported to have

${ }^{31}$ For the preaching about heaven, see Le Jeune's Relation of 1637, in Relations 11: 101-103; Le Mercier's Relation of the Hurons of 1637, in Relations 13: 29-31 \& 39-41; Jérôme Lalemant's Relation of the Hurons of 1643-44, in Relations 26: 179-81, 193-95 \& 203-205; and J. Lalemant's Relation of 1647, in Relations 31: 149-51.

${ }^{32}$ Le Jeune's Relations of 1637 and 1638, in Relations 12: 161-65; \& 14: 205-17.

${ }^{33}$ J. Lalemant's Relation of 1645-1646, in Relations 29: 65-67. 
accommodated Huron traders, as well as the Attikamègue, over winter. The Huron parties repeatedly wintered in Sillery during the 1640s. The settlement also continued to accept more Algonquin, Innu and other people who intended to reside there. ${ }^{34}$

The other reason for the delay was that native people had to cope with the Jesuit resistance to mass baptism. Instead, the priests only baptised those individuals who showed sufficient piety and constancy of faith. Because of this individual-based baptism, it was impossible for all the residents to be baptised within a short period. Being a Christian was also not a prerequisite for entering a settlement. In order to remain in the settlement, however, native residents had to become model Christians. In other words, they could not simply request one rite or another from time to time. In the Relation of 1642, Father Jérôme Lalemant never failed to mention the religious requirement given to Sillery residents. Perhaps based on this unwritten Jesuit strategy, the colonial French authorities announced to the Sillery headmen in the same year that non-Christians were not allowed to remain in the settlement. In 1645, Father Lalemant was finally able to claim that all the native Sillery residents were either Christians or catechumens. A year later, in the Relation of 1646, he noted that almost all the indigenous residents there had been baptised. ${ }^{35}$

\section{Christianity as a Key to Service and Worldly Benefits}

For Amerindian converts, accepting Christianity meant access to human and material resources through the missionaries, especially if they resided near the French settlements. Like their Iberian predecessors in Japan, the French missionaries and sympathetic officials provided indigenous people with all kinds of social services and other related benefits. For instance, the Jesuits provided native children and, later, adults with food and clothing at seminaries. The Ursuline Nuns did the same for Amerindian girls. Also, as mentioned above, accepting Christianity provided the decreasing native Laurentian population with an opportunity to get French help to re-establish a community in

\footnotetext{
${ }^{34}$ Vimont's Relation of 1642-1643, in Relations 24: 67-69 \& 103-105; J. Lalemant's Journal des PP. Jésuites of 1645, in Relations 27: 91; J. Lalemant's Journal des PP. Jésuites of 1647, in Relations 30: 155; and J. Lalemant's Journal des PP. Jésuites of 1649, in Relations 34: 63.

${ }_{35}$ J. Lalemant's Journal des PP. Jésuites of 1645, in Relations 27: 121; and J. Lalemant's Relations of 1646 and 1648, in Relations 29: 65; \& 33: 49-51.
} 
the réductions. The Jesuit missionaries and Hospital nuns made efforts to save the destitute or ill among the Amerindians. Moreover, in the fur trade, native Christians were better treated than non-Christians receiving better prices for furs, additional presents, and places of honour at councils held at the French settlements. ${ }^{36}$

There were several examples that support this linkage of social services with Christianity. Following the first réduction of Sillery, the collaborative French-Amerindian réduction programme expanded to other areas, such as Trois-Rivières, Tadoussac and île d'Orléans. The hospital in Quebec was always crowded with native patients. Also, young Huron men who wintered near the French settlements in the early 1640s received both material help and baptismal instruction from the missionaries. According to Father Vimont in 1643, catechism instruction to Algonquin children in Sillery was accompanied by such rewards as knives, bread, chaplets, caps and axes. ${ }^{37}$

There was almost always a strong connection between the fur trade and Christianity in the minds of native people. In the village of Ihonatiria, able-bodied Huron traders requested baptism. This village was the only place at which the Jesuits were able to establish a small missionary centre after reopening the Huron mission in the mid1630s. Co-incidentally it was one of the villages that had established a trading relationship with the French in Quebec. Also, in the 1630s, when the Hurons who asked for baptism were mostly the ill or dying, a small number of healthy men, who had made trade journeys to Quebec, sought baptism or helped with missionary work. They expected preferential treatment in trade as Christians. ${ }^{38}$

\footnotetext{
${ }^{36}$ For the preferential treatment of indigenous converts, see Paul le Jeune's Relations of 1636, 1637 and 1639, in Relations 9: 287-89; 16: 33; 12: 243-47 \& 257-59; also cited in Bruce G. Trigger, the Children of Aataentsic (Kingston \& Montreal: McGillQueen's University Press, 1976), 547. It was not difficult for the French settlers in Quebec to identify native Christians because the men of the villages that accepted missionaries normally carried a priest's letter to the missionary station in Quebec. See the letter of Barthélemi Vimont, superior, to Mutius Vitelleschi, general superior, at Rome, from Quebec, 28 September 1643, in Campeau, Monumenta, 5: 631-34, esp. 631; Charles Garnier to Henry de Saint-Joseph, at Paris, from [the Huron village of] Saint-Joseph, 14 May 1646, in ibid., 6:.471-76, esp. 473; Garnier to Saint-Joseph, at Paris, from Saint-Marie, 25 April 1648, in ibid., 7:242-46, esp. 243.

${ }^{37}$ Vimont's Relation of 1642-43, in Relations 23: 309-13.

${ }^{38}$ For the positive effect of trade on the mission, see Jean de Brébeufs Relation of the Hurons of 1635, in Relations 8: 101-103, 149-51; and Le Jeune's Relations of 1637 and 1638, in Relations 11: 135; \& 14: 77-83. See also Trigger, op. cit., 546-550.
} 
The Amerindian expectation to the missionary version of Christianity, however, went beyond access to social services. The native people lived in a world where shamanism ruled every aspect of life. They did not consider that Christianity and church would remain strictly within a European concept of religious and philanthropical rôles. Through Christianity they expected such worldly shamanistic benefits as they would seek traditionally from indigenous shamanism, including animism, such as locating game animals and curing disease. ${ }^{39}$

In the religious practice of neophytes and potential converts, the Christian God brought the additional power to control weather to protect food crops, for example. In 1628, the Hurons in the village of Ihonatiria prayed with Father Jean de Brébeuf in front of a crucifix for rainfall and a plentiful harvest. In June 1635 again, the people of Ihonatiria sought help from the Jesuits after they found a native shaman, the so-called 'arendiowane' or 'arendiwane', unsuccessful in bringing rain. Under the priests' instruction, they made daily processions and a novena, or a cycle of nine prayers, and finally they enjoyed abundant rainfall. Their participation in the same religious prayers brought rain again in late July, and consequently a good harvest. In the dry summer of 1638 also, the Huron villagers of Ossossané depended on Christian Masses for securing rainwater from the sky. ${ }^{40}$

Both the Hurons and the Jesuits were responsible for establishing the image of God as the weather controller. The Huron people had a shamanic custom of throwing tobacco into a fire in honour of the sky for a good harvest and other benefits. The native people also had a custom of asking their shamans to bring rainfall by means of dreaming, feasting and dancing. The shamans claimed that they could cause and stop the rain and winds. Both in 1628 and in 1635 the Huron people asked the priests for help only after the failure of their shamans. The missionaries took advantage of this opportunity to persuade the Hurons that praying only to God could bring rain and a harvest. The priests acted as substitutes for the rain-bringing shamans. Simultaneously Christian prayers replaced traditional Huron activities to control the weather. ${ }^{41}$

\footnotetext{
${ }^{39}$ For the example of animism, see Brébeuf's Relation of the Hurons of 1636, in Relations 10: 159-69.

${ }^{40}$ Brébeuf s Relation of the Hurons of 1636, in Relations 10: 35-49; and J. Lalemant's Relation of the Hurons of 1639, in Relations 17: 135-37.

${ }^{41}$ Brébeuf's Relations of the Hurons of 1635 and 1636, in Relations 8: 123-25; \& 10: 193-95; J. Lalemant's Relation of the Hurons of 1642, in Relations 23: 55; and Paul Ragueneau's Relation of the Hurons of 1647-48, in Relations 33: 221.
} 


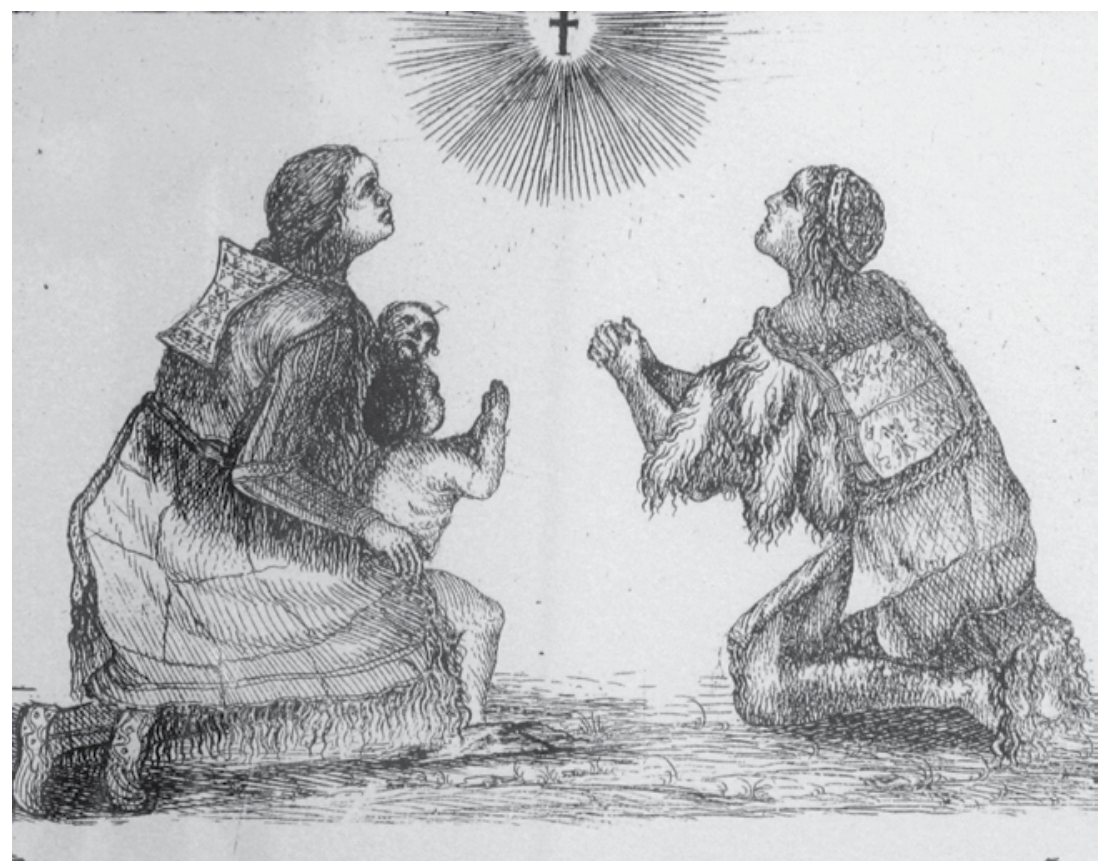

Source: Carte de la Nouvelle France, in Francesco Giuseppe Bressani, SJ, Novae Franciae accurata delineatio, 1657; (c) Dép. Cartes et plans/Bibliothèque nationale de France

11. Seventeenth-Century Image of Native Women and Children Praying to God

A similar association of prayer with material rewards was applied to hunting and fishing. The Amerindians expected to use divine Christian power to summon wildlife. In 1638, Father François Joseph le Mercier referred to a Huron headman, an influential pro-Jesuit supporter in Ossossané, who was described as having spoken honourably of God and His law, and to have attributed the success of his fishing to Christian prayers. ${ }^{42}$

The Innu and Algonquin peoples, too, considered the Christian God to be capable of contributing to successful hunting. Father Le Jeune made repeated references to their belief. In the Relation of 1639, he referred to an old Innu man. The man told his son-in-law to ask God for a moose when he went out hunting. Father Le Jeune also wrote

${ }^{42}$ Le Mercier's Relation of 1638, in Relations 15: 125. 
about a band of Innu hunters who wintered away from Sillery in 1638-39. When they returned to the réduction, they told the missionaries that they had maintained a constant supply of their game by thanking God for every catch. In the two Relations of 1639 and of 1640, native Christians in Sillery made it a rule to fall on their knees and thank God for the game they had just caught and killed. Father Vimont wrote about a neophyte in the same settlement. Before every hunt for wild game, this convert prayed to God for success with the aid of a crucifix..$^{43}$

It was the missionaries who encouraged their neophytes and potential converts to pray to God for successful hunting. To borrow Father Paul Ragueneau's expression, presumably conveyed to the native Christians, God was the sovereign Lord of animals as well as of men. In December 1633, Father Le Jeune proposed that his hungry Innu host should offer prayers to God, who had 'made heaven and earth', before departing for hunting. According to him, these native people consequently caught beavers, porcupines and moose, while the 'apostates'- probably those who resorted to traditional hunting rituals-returned without game. The Relation of 1647-1648 notes that the Jesuits attempted to replace manitou with the Christian God as the spirit that would bring success in hunting. For example, among the Abenakis, to whom the Jesuits expanded their mission with the help of Innu converts, Christians and non-Christians coexisted. When Father Gabriel Druillèttes accompanied his Abenaki converts in their winter hunting of 1647-48, only his Christian party that believed in God for the successful chase was reported to have enjoyed sufficient game. ${ }^{44}$

By becoming Christians, the Amerindians also expected help in warfare from the Jesuits. In 1637, Father Le Jeune referred to indigenous men, apparently Innu, who were being instructed about abandoning some non-Christian customs before being qualified to become Christians. They sought the priests' prediction of a future war and God's assistance in it. Accordingly they learnt from the missionaries prayers for their safe return from battle. In the Huron country also, the people expected that the missionaries would intervene with God in order to

\footnotetext{
${ }^{43}$ Le Jeune's Relations of 1639 and 1640, in Relations 16: 49-51; 18: 149 \& 157; and Vimont's Relation of 1642, in Relations 22: 57-59.

${ }^{44}$ Le Jeune's Relation of 1634, in Relations 7: 145-59; Lalemant's Relation of 16471648, in Relations 32: 273; and Ragueneau's Relation of 1651-52, in Relations 37: 195.
} 
predict for them where their enemies were and in what force they would come. ${ }^{45}$

There was an Amerindian belief in manitou and an oki as personal guardians in warfare. During one of his first meetings with Innu bands, Father Le Jeune learnt that they believed that manitou was present in battles. The manitou, he stated, would protect those whom it favoured, and would kill their enemies. Even though Father Brébeuf did not use the word $o k i$, he reported on a similar belief among the Hurons, who believed in a kind of war divinity that they imagined to be a little dwarf. On departure for a battle, the dwarf would caress those who would enjoy a victorious return, but would strike on the forehead those who would lose their lives. Also the sun, or Agreskoui, was war divinity among the Huron and Iroquois peoples. In 1648, Father Ragueneau identified the sun as the Huron people's war divinity. Later in 1653, Father Francis-Joseph Bressani referred to it as Agreskoui. Also, Huron shamans, or arendiwane, claimed that they were capable of various war-related predictions, such as whether a war would be successful, whether the enemy was approaching a village, how many were coming, and where they waited in ambush. This type of shaman resorted to an oki that he claimed would enter his body or appear to him in a dream or a vision. ${ }^{46}$

Furthermore, the priests inadvertently helped the Amerindians to associate God with manitou or a great oki. It was Father Le Jeune who first identified manitou as the devil who worked against God, or so he implied to a group of the native people. Father Le Jeune's words enabled the Innu people to imagine that the European God was equivalent to their manitou. According to his Relation of 1634, he himself took the initiative for explaining even to an Innu group that manitou was the devil, which would hinder God. He wrote that he had said to those who felt frightened of manitou, 'Do not fear, the devil will not harm you as long as I am with you, for he fears those who believe in God; if you will believe in God, the devil will flee from you'. According to Father Le Jeune in the Relation of 1636, an Innu shaman called God

\footnotetext{
${ }^{45}$ Le Jeune's Relation of 1637, in Relations 11: 217; and J. Lalemant's Relation of 1639, in Relations 17: 119-21.

${ }^{46}$ Le Jeune's Relation of 1634, in Relations 6: 175; Brébeuf s Relation of the Hurons of 1636, in Relations 10: 183 \& 197; J. Lalemant's Relation of the Hurons of 1640, in Relations 19: 83; and Ragueneau's Relation of 1647-48, in Relations 33: 193 \& 221-25; and Francis-Joseph Bressani's Relation of 1653, in Relations 39: 13 \& 207-209.
} 
'your manitou' in front of Father Jacques Buteux. Soon the Innu learnt to regard God as the good manitou and the devil as the bad manitou. ${ }^{47}$

The Hurons also understood God as a version of ondaki or an oki. ${ }^{48}$ In 1642, Father Lalemant recounted a story about a non-Christian Huron man who fasted for a vision of an oki. In this indigenous imagination, an oki resided in the sky and showed up on the ground by descending from the sky, then ascending afterwards. In the Relation of 1636, Father Brébeuf stated that he explained about God by metaphorically using this Huron idea of an oki in the sky, which ruled the weather and climate. ${ }^{49}$

For non-Christian Amerindians to understand any spirituality, their only possible framework for comprehension would come from their indigenous shamanism based on spiritual powers like manitou or an oki. Beyond its religious realm, Christianity also represented a means to predict astronomical phenomena, or changing weather and climate patterns. This did not, however, persuade the native people to become Christian in a Jesuit sense. Quite the opposite: the priests' use of their astronomical knowledge only strengthened the identification of themselves as powerful and formidable shamans. This identification even enhanced the interconnection between traditional shamanism and Christianity in the mind of the indigenous people. In the Relation of 1639, Father Lalemant recounted his and his brethren's experience after they predicted the eclipse of the moon and sun, which the Huron people feared. The indigenous people began to imagine that the priests could recognise and determine all future events, including the upcoming harvest and war strategies of enemies. At the same time, the Amerindians were critical of the priests for not warning them of outbreaks of epidemic diseases and for not offering preventive or curative remedies to them as shamans would profess to do. ${ }^{50}$

The Jesuits were even compelled to adapt themselves to indigenous shamanistic activities. Three examples are pertinent. One was the use

${ }^{47}$ Le Jeune's Relation of 1634, in Relations 6: 175; 7: 85-87 \& 181-83; Le Jeune's Relation of 1636, in Relations 9:75-77; and Le Jeune's Relation of 1637, in Relations 12:7-9.

${ }_{48}$ There were several $o k i$, or ondaki to be more precise, not just one in the Huron minds.

${ }_{49}$ Brébeuf's Relation of the Hurons of 1636, in Relations 10: 161; and J. Lalemant's Relation of 1642, in Relations 23, 155-57.

${ }_{50}$ J. Lalemant's Relation of 1639, in Relations 17: 119-21; and also partially quoted in Axtell, op. cit., 102. 
of feasts, typical native rituals. In 1637, Father Buteux held a feast to which he invited Innu and Attikamègue peoples in Trois-Rivières to persuade them to pray for God. The other examples involved dreams, on which Amerindians relied for making decisions in every aspect of their lives. In January 1634, Father Le Jeune feared being deserted by his Innu hosts, who tried to conserve their food by abandoning him. To save himself, the Father claimed that he had dreamed just the opposite, that the Innu would capture two moose. Again in 1637, to convert an Algonquin group whose dreams prevented them from accepting the faith, Father Le Jeune warned them, 'We will dream that you all will be converted'. These cases imply that the native people had opportunities to believe that the Christian priests held a feast as they did, and that they made predictions and decisions as in shamanism. ${ }^{51}$

\section{Christianity for Healing Power}

The curative method that the Jesuits applied to the ill caused the latter to associate Christianity with healing power. This belief was stronger among the Amerindians than among the Japanese, who had immunity to European diseases and suffered little from them. The Jesuit accounts contain numerous accounts of anonymous Amerindians who sought baptism when they wished to survive a sickness or regain their health. In their minds, becoming a Christian, or even being baptised by European priests, would bring succour from fatal diseases. Simultaneously most converts kept their traditional curing rituals which, at least in their minds, did not conflict with Christianity.

Because the relationship between missionary healers and ill indigenous people varied slightly according to region, there were two basic versions of this acceptance of the curative God. In the first adaptation model, healing power was interpreted positively, as seen especially among the peoples near the French settlements, who met French settlers beside the Jesuits. This idea was conspicuous among nomadic peoples, such as the Innu, Algonquin and Attikamègue, as well as the later Huron refugees to Quebec, all of whom eventually lived near the French settlements in the Saint Lawrence Valley. In the second model, the priests' power was interpreted negatively, as killing power. This perspective was common especially among remote peoples, such

${ }^{51}$ Le Jeune's Relation of 1634, in Relations 7: 169; and Le Jeune's Relation of 1637, in Relations 11: 203; \& 12: 171. See also Axtell, op. cit., 111-12. 
as the semi-sedentary Hurons by distant Lake Simcoe, who met few Europeans except for the missionaries, whom they took to be typical Europeans.

\section{a. Positive Interpretations}

The nomadic peoples around the French settlements asked priests to baptise them when they were ill or dying. Baptism was often requested as an addition to traditional healing. In the Relation of 1633, a grandmother of a sick Algonquin child said that she would be satisfied to have Father Brébeuf baptise the child, given that the Father could cure him. The child's parents and grandmother tried baptism as another option for healing, in addition to a native healing ritual, which included howling, playing a tambourine-like instrument, blowing on the head of the child and whistling. In the winter of 1647-48, Attikamègue Christian parents of an ailing child turned to God only after the failure of a native shaman's healing rituals. According to Father Ragueneau, this neophyte soon recovered his health. This last incident also implies that the curative use of baptism and shamanistic healing coexisted even among converts. ${ }^{52}$

Requests for baptism were mainly for curing illness. In 1634, Manitouchatche, an Innu on good terms with the missionaries, begged for baptism to recover from his illness. In 1636, Father Le Jeune noted that the Innu people tried to summon the missionaries in order to save their stricken children by baptism. The same case was reported among the Algonquin in 1637. In 1647, after falling extremely ill, an Abenaki shaman sent for Father Gabriel Druillettes to heal him through baptism, and he regained his health. ${ }^{53}$

The indigenous people also believed in the missionaries' healing power in their other sacraments and prayers. In 1637-38, an Innu group who had settled in Trois-Rivières found their people afflicted with illness. In an attempt to avoid the spread of disease, they decided at a council to have recourse to God, to pray to Him regularly and to seek religious instruction from the priests. In 1643-44, a native woman in Sillery, who may have been a Christian or else in the process

${ }^{52}$ Le Jeune's Relation of 1633, in Relations 5: 233; and J. Lalemant's Relation of 1647-48, in Relations 32: 297-99.

${ }^{53}$ Le Jeune's Relation of 1634, 1636 and 1637, in Relations 6: 117-27; 8: 247; \& 11: 131-33; and J. Lalemant's Relation of 1647, in Relations 31: 197-99. 
of receiving instruction for baptism, had an extremely sore throat. She asked a missionary to cure her. In the Relation of 1645-46, a sick Algonquin man approached the Jesuits in Huronia. The priests helped him to pray to God for his cure. According to Father Ragueneau, this neophyte soon recovered his health. In the same report, on two occasions, another Algonquin neophyte declined conventional curative rituals and instead sought the help of the missionaries to pray to God for curing his sick child. Father Ragueneau proudly stated that the child recovered his health in both cases. Yet his deliberate reference to this model Christian also suggests that many other less pious neophytes tended to rely on both Amerindian healing rituals and Christiansacraments. ${ }^{54}$

In the second quarter of the seventeenth century, this belief in the Christian God's ability to heal was accepted by Amerindians in areas remote from the French outposts, and by the Huron people. To a large degree, Christianity functioned among the Huron people in the same positive way as among the nomadic peoples such as the Innu and Algonquin. The Hurons asked priests to baptise them when they were ill or dying. They also believed in the healing power of the missionaries' other sacraments and prayers. Baptism was requested as a substitute for native healing rituals. ${ }^{55}$

In a similar manner, the indigenous peoples expected that a safe pregnancy and birth could be ensured by the Jesuits. According to Father Lalemant, in the Relation of 1647, a Christian woman in danger of death from child bearing had recourse to the missionaries who visited the Island of Miskou, in the Gulf of Saint Lawrence. The lives of both the woman and her baby, baptised immediately at birth, were saved. In the Relation of 1647 also, a native catechumen and her unborn baby in Sillery were reported to have been saved by prayers to God when they were almost dying. ${ }^{56}$ Because the Jesuits could not really guarantee benefits through their prayers and actions, they received blame as well as gratitude for the results of events beyond their control.

${ }^{54}$ Le Jeune's Relation of 1638, in Relations 14: 263-65; Vimont's Relation of 164344, in Relations 26: 79-81; and Ragueneau's Relation of the Hurons of 1645-46, in Relations 30: 115-17.

${ }_{55}$ Brébeuf's Relation of the Hurons of 1636, in Relations 10: 13; Le Mercier's Relation of the Hurons of 1637, in Relations 13: 85-87; and Joseph-Marie Chaumonot's letter to the General Superior Mutio Vitelleschi, at Rome, from the country of the Hurons, 24 May 1640, in Relations 18: 23-27.

${ }^{56}$ J. Lalemant's Relations of 1647 and 1647-48, in Relations 32: 51-53; 277-79. 


\section{b. Negative Interpretations}

Other people believed baptism of the dying, along with other sacraments, as the acts of the Jesuits, to cause immediate death. This conviction was based on the tendency of priests to baptise the dying without reservation. In the Relation of 1636, Father Le Jeune referred to an Innu or Algonquin woman who asked the missionaries not to baptise her sick husband, for she did not want to lose him immediately. In the early 1640s, native non-Christian residents in Sillery firmly believed that baptism and prayer together would cause them to die. In 1647, a non-Christian patient in the hospital of Quebec rejected the sacrament of life that he imagined would cause his death. ${ }^{57}$

This negative interpretation grew even stronger among the Huron people. In understanding the power to influence lives and health, the Hurons received more negative impressions than positive ones. They suspected that killing power, rather than healing power, existed in anything related to the missionaries, such as pictures of Jesus or the Virgin Mary, European kettles, European clocks, the priests' books and their tabernacles. One individual who maintained a traditional animistic belief asked the priests whether they were creating the malady in the missionaries' house to spread disease. Some imagined that the Jesuits were practising their sorcery by keeping their house entrance closed when the priests were merely engaged in morning meditation. ${ }^{58}$

There were outbreaks of epidemics that altered the native perception of the evangelists who propagated the belief in God. The resumption of the Huron mission in the mid-1630s coincided with repeated outbreaks of European-derived epidemics, to which the Amerindians were susceptible. Because baptism was mainly given to the diseased or dying, not many survived baptism. Referring to both baptism and disease within a single paragraph, Father Jérôme Lalemant wrote implicitly to Superior General Mutius Vitelleschi that one thousand baptisms accomplished by the priests among the Hurons in 1640 were closely connected with the fatal damages by contagious diseases. In 1653, Father Francis-Joseph Bressani admitted retrospectively that, of the twelve thousand Huron people whom the Jesuits claimed to have baptised in the mid-1630s, most of them did not survive diseases. Faced

57 Le Jeune's Relation of 1636, in Relations 9: 61; Vimont's Relation of 1642-43, in Relations 24: 25-27; and J. Lalemant's Relation of 1647, in Relations 31: 159.

${ }^{58}$ Le Mercier's Relation of 1637 and 1638, in Relations 14: 103-105; \& 15: 17-35; J. Lalemant's Relation of 1640, in Relations 20: 31-33 \& 37. 
with the numerous deaths by illness, the Huron people instinctively believed the causes to rest in the Christian mission. ${ }^{59}$

Even though the Hurons were not the only Amerindian groups to suffer epidemics, there were four basic reasons for them to reach such a conclusion. First, the missionaries stayed all year round in the Huron country rather than making seasonal visits from Quebec, as they did to nomadic bands. Even the residents in the réductions closer to Quebec had the option of leaving behind the Europeans when the native people went off to winter hunting. ${ }^{60}$ Second, for the Hurons, the priests and their assistants were the only Europeans the indigenous villagers saw because of the distance from the French settlers in Quebec or TroisRivières. Thus, they thought that all the Europeans were shaman-like priests. Third, except for traders and seminarians, the Huron people had little opportunity to enjoy such medical and material assistance as might be expected at the French outposts and the native réductions. Fourth, the Hurons were unable to understand the evangelists' intention of travelling such long distances to live amongst them. Even more puzzling was the fact that the missionaries, unlike native shamans, claimed no material profit or advantage for themselves. ${ }^{61}$ In these circumstances, the Hurons were prone to associate mortal epidemics and subsequent deaths with the missionaries.

\section{c. Factors behind the Belief in Healing Power}

To understand the Amerindian view of Christianity as a cause for healing and, at the same time, for killing, one should consider the indigenous beliefs about disease. Although the Jesuits left behind no detailed observation of Innu or Algonquin ideas of disease, Father Le Jeune, at least, recognised the Innu belief that the manitou would cause death and illness. According to Father Ragueneau, the Hurons recognised three kinds of disease. The first kind was common and curable with natural remedies. The second kind was caused by the materialistic

59 J. Lalemant to Mutius Vitelleschi, general superior, at Rome, from the country of the Hurons, 1 April 1640, in Campeau, Monumenta, 4: 467-70, esp. 468-69; and Francis-Joseph Bressani's Relation of 1653, in Relations 39: 145. See also Father Le Mercier's deliberate reference in 1637 to the first adult Huron baptised in health as well as to the recovery of those baptised in sickbed, in Relations 14: 77-79 \& 109.

${ }^{60}$ Vimont's Relation of 1643-44, in Relations 25: 113.

${ }^{61}$ Father Lalemant pointed to this last reason. See his Relation of the Hurons of 1639, in Relations 17: 125. 
yearning of the sick person's soul, and could be cured by satisfying that yearning. The third kind was caused by witchcraft or a spell that some shaman, or 'sorcier', cast on a person. It could only be cured by exorcising the spell from the patient's body. It was the Innu's belief in illness caused by manitou, as well as the Hurons' belief in spells causing illness, that helped the native people to believe in both the healing and killing power of Christianity. ${ }^{62}$

The nomadic peoples, to begin with, interpreted God's power to control epidemics and deaths from their traditional shamanistic perspectives. The people feared powerful shamans whom they believed to kill people by charms or imprecations made to the manitou. The traditional idea that the manitou had power to control illness helped the nomadic peoples near the French settlements to suspect that God, or the Christian 'manitou', had the same power. Also, their identification of the Jesuits with shamans enhanced the idea that the priests could save the sick as did native healing shamans who were traditionally believed to communicate with manitou. When the Algonquin people in Trois-Rivières accused the missionaries of causing serious illness by witchcraft in 1638-39, they began to rely on Christian sacraments and to ask for the Eucharist to save them. This was because native shamans claimed that their communication with the manitou was unable to cure their patients infected with strong European diseases. It was also because the people attributed illness to the priests rather than to their traditional shamanism. Once the indigenous people regarded God as the Christian manitou that caused disease and death, they thought that only God, as well as the priests' manitou, could control their lives. ${ }^{63}$

The Huron people, too, had their own notions of disease and death, which were applicable to the understanding of God as the arbiter of life. Two kinds of shamans were in charge of healing. One kind, called 'ocata' or 'saokata', diagnosed the nature of a disease. The other was an apothecary called 'ontetsans' or 'aretsans', who treated illnesses. From another standpoint, healing shamans were called 'arendiwane', meaning one whose supernatural power is great, and 'oki', metaphorically

${ }^{62}$ Le Jeune's Relation of 1634 \& 1636, in Relations 7: 181; \& 9: 81, 209-11; and Ragueneau's Relation of the Hurons of 1647-48, in Relations 33: 199.

${ }^{63}$ Le Jeune's Relation of 1633, 1636, 1637 and 1639, in Relations 5: 233-39; 8: 271-73; 9: 75-77; 12: 7-9; \& 16: 53-55. The idea of a powerful God may have been enhanced by the fact that the French settlers did not fall sick as easily as the Amerindians and the French patients recovered early. See also Le Jeune's Relation of 1636, in Relations 9: 139-41. 
the same as the powerful spirits in which the Huron people believed. This type of shaman was believed to communicate with the powerful spirit that would either enter his body or appear to him in his dreams and visions. There was a belief that some dangerous shamans, called 'oki ontatechiata', could kill people by spells. In Ossossané, for example, the Jesuits were invited to the preparation for a healing ritual in 1638-39. ${ }^{64}$ In this indigenous conceptual framework, the Hurons understood God as the Christian oki and the Jesuits as shamans who could cure and kill with the help of oki.

For those Amerindians whose first motive for baptism was to survive illness, however, requesting healing from God through the priests meant that it was specifically for curative purposes and for nothing else. Father Le Jeune admitted that, even though the Innu and Algonquin people sought curative help from the missionaries, those who recovered their health ceased to follow other religious advice provided by the evangelists. This was also the case with the Hurons. Father Lalemant criticised the fact that most ailing villagers in the country sought baptism only for survival and, on their recovery from illness, ceased to obey the Jesuits. ${ }^{65}$

The missionaries were just as responsible as the Amerindians for creating a link between their faith and death or recovery in an indigenous way. First of all, as the Iberian missionaries had done to Japanese Buddhist and Shintô priests, the priests attempted to criticise native shamans and increase their own reputation as powerful shamans. They used their scientific knowledge and Christian prayers, mentioned above, at every opportunity to impress people. In 1637, Father Le Jeune noted that he and his brethren were considered to be 'Manitousisiouekhi', which meant those who were superior to men because of their acquaintance with manitou. By the early 1640s, Father Brébeufs reputation as a powerful shaman was widespread, even beyond Huronia, among the neighbouring Atiwandaronk, or the Neutral people. ${ }^{66}$

It was also the missionaries who presented the idea of accepting Christianity as the method to prevent the outbreak of disease. According to Father Le Mercier in the Relation of 1637, Father Brébeuf was

${ }^{64}$ J. Lalemant's Relation of 1639, in Relations 17: 165-75 \& 211-13; Ragueneau's Relation of 1648, in Relations 33: 193 \& 219-21. For the meaning of arendiwane, see Tooker, op. cit., 91 \& note 76.

${ }^{65}$ Le Leune's Relation of 1637, in Relations 11: 149-83; and J. Lalemant's Relation of the Hurons of 1642 and 1644-45, in Relations 23: 117-19; 28: 39-41 \& 77.

${ }^{66}$ Le Jeune's Relation of 1637, in Relations 11: 257-59; and J. Lalemant's Relation of 1640-41, in Relations 21: 207-09. 
invited to a council of Ossossané, which asked him for help in preventing disease. Of the several conditions for help he proposed to the council, the first and most important was to believe in God and keep His commandments. ${ }^{67}$

Furthermore, the healing sacraments by the priests and their occasional ineffectiveness increased imaginary association with killing ceremonies. Healing was accompanied by a crucifix and sacred water. The great majority of people who received baptism or other rituals were those, including children, who were extremely ill, especially in Huronia and surrounding regions. The patients were infected with unfamiliar European diseases and thus needed medical care or at least nursing. The Christian healing sacraments never stopped the epidemics even in Ihonatiria, a village where the missionaries founded the first missionary station in Huronia. One should remember that, because this village later disappeared, after the steep decline of population, the priests had to relocate their station to another village of Ossossané ${ }^{68}$

\section{Benefits through Religious Objects}

The native converts treasured religious objects used for Christian sacraments, just as the Japanese neophytes and the Europeans had done. Such items included medals, rosaries, crucifixes, sacred relics and holy water. According to Father Le Jeune as early as 1638, sacred water grew in repute as a curative means among the Amerindians in Sillery. Crucifixes and rosaries also became treasured items among the Christians in this réduction by the early 1640s. Also in 1647, a Christian headman in this settlement held a crucifix and a rosary with a medal in order to harangue his people for combat. This chief may have intended to raise morale or to achieve a victory through these items, or both. In 1639, Father Le Jeune described an Algonquin man who hung a rosary around his ill child's neck for God's healing. Attikamègue women also hung a rosary around their little children's necks for God's protection in 1647-48. Father Lalemant wrote from Quebec in the Relation of 1646 that indigenous Christians, who stayed somewhere near Quebec

${ }^{67}$ Le Mercier's Relation of 1637, in Relations 13: 169-71.

${ }^{68}$ Le Mercier's Relation of the Hurons of 1637, in Relations 13: 165; and Lalemant's Relations of the Hurons of 1640 and 1640-41, in Relations 19: 129-31; \& 21: 233; and Joseph-Marie Chaumonot's letter to Philippe Nappi, Supérior de la Maison Profess, at Rome, from the Huron country, 26 May 1640, in Relations 18: 25-27. 
or Trois-Rivières, wore religious tools imported from France for healing illness and the safe delivery of babies. ${ }^{69}$

The Amerindians were already culturally predisposed to accepting Christian rewards from the use of amulets. In effect, these native peoples had already kept charms for worldly benefits. In 1635-36, Father Le Jeune learnt that the native Innu or Algonquin people around the French settlements, albeit not all, carried some article prescribed by the manitou for health and longevity. In 1642, an indigenous resident of Sillery kept a special stone that he believed would bring, with the help of the manitou, good fortune or success in hunting and warfare. That was the kind of stone, like a gallstone, that was found in internal organs, like a heart or a throat, of such game as elks or moose. ${ }^{70}$

The Jesuits discoursed Huron amulets in great detail. According to Fathers François du Péron and Jérôme Lalemant, all or nearly all the Huron people had amulets that were believed to bring them desired success or benefits. Father Ragueneau noted that the charms were stones or snakes. The people believed that they would be lucky with the amulets during hunting, fishing, trading and gambling. They believed especially in the effect of 'onniont', a kind of serpent in the shape of an armoured fish that was bartered at a high price from the Algonquin. In 1639, Father Lalemant referred to the deep attachment to amulets even among those who were baptised. ${ }^{71}$

Yet it was the missionaries who introduced to the Amerindians the physical tokens of the Christian faith as effective amulets. The missionaries let their patients drink the holy water or poured it over the afflicted parts of their bodies in the hope of healing them. In Huronia, the missionaries hung a crucifix before the entrance of their dwelling and another on top of it so that God might preserve them from any malady. In 1636, the missionaries applied a 'Relic of Our Blessed Father St. Ignatius' to a Huron woman for the safe delivery of her baby. In 1637, Father Brébeuf explained to his Huron host that holy

${ }^{69}$ Le Jeune's Relations of 1638 and 1639, in Relations 14: 223; \& 16: 47; Vimont's Relations of 1642-43 and 1643-44, in Relations 24: 91-93; \& 25: 187-89; and J. Lalemant's Relations of 1645-46, 1647 and 1647-48, in Relations 29: 197-99; 31: 17375; \& 32: 287.

${ }^{70}$ Le Jeune's Relations of 1636 and 1637, in Relations 9: 119-21; \& 12: 13-15; and Vimont's Relation of 1642, in Relations 22: 95.

${ }^{71}$ François du Péron's letter to Joseph-Imbert du Péron, from Ossossané, 27 April 1639, in Relations 15: 181; J. Lalemant's Relation of the Hurons of 1639, in Relations 17: 211; and Ragueneau's Relation of the Hurons of 1647-48, in Relations 33: 211-15. 
water served to drive away the devils. In Tadoussac in 1642-43, Father Jean de Quen told a non-Christian Innu to discard his native amulets, including his special pouch containing a traditional charm, that he was using to try to save his stricken son. The priest instead suspended a crucifix above the head of the child for its healing effect. ${ }^{72}$ Yet, considering this last incident along with the amulets found in Sillery and the Huron converts' retention of traditional charms, the Christian amulets do not seem to have fully replaced the native ones.

\section{Conclusion}

In order to to understand how former non-Christians accepted and practised Christianity, one should not focus on the individuals' depth of belief or on the resemblance to the European Christian belief. It is more important to study how the people used their limited comprehension based on their conventional non-Christian concepts to digest what the foreign missionaries preached as Christianity. This religious practice should be treated collectively rather than individually. For this, the case study of Japan provides a typical example of how nonChristians accepted Christian belief and practice, and this case study can be applied to the Amerindian conversion to Christianity.

For a people without a Euro-Christian cultural background, Jesuit preaching and Christianity were understood within the context of their own traditional non-Christian culture. This was certainly the case with both the Japanese and the Amerindians. What Christianity meant to these peoples was exactly what the missionaries presented to them, not only in Christian instruction but also in evangelistic activity. Beyond a purely religious framework, the missionary work in Japan and New France helped converts to replace existing social ties, to imagine access to worldly benefits, to seek healing from the faith and even to imagine spiritual power in Christian items. That was not a simplistic process of replacing non-European religions with Christianity in such a way as Cushner proposes. ${ }^{73}$

72 Brébeuf s Relation of the Hurons of 1636, in Relations 10: 73; Le Mercier's Relation of 1637, in Relations 13: 233; \& 14: 37-39; Vimont's Relation of 1642-43, in Relations 24: 21-23 \& 133-35; and J. Lalemant's Relation of 1647, in Relations 31: 197-99.

${ }^{73}$ Cf. Cushner, op. cit., 3-4 \& 198. 
As was the case with the Iberian predecessors, the French missionaries took full advantage of the native concepts that were useful for their evangelisation. This attitude in the missionary approach was the primary determinant for creating the Christian faith among the Japanese and the Amerindians. As with the Japanese, the indigenous people in New France developed what they imagined to be the Jesuit version of Christianity, both under the direction of priests and in their own native terms.

Subsequently in New France, Christianity united the native people socially, enabled them to gain access to social services and worldly benefits, and raised expectations of healing by means of Christian amulets. Yet these spiritual elements were not the indigenous people's conscious adaptation of the Christian messages. ${ }^{74}$ They were more likely to have been the natural responses to the Jesuit preaching in native terms that inevitably used analogies to Amerindian cultural aspects. The evangelistic efforts invoked associations between Christianity and worldly shamanistic benefits. The preaching method that the missionaries adopted for explaining Christianity in a way comprehensible to indigenous people was the most instrumental in creating an indigenous version of Christianity.

Thus, in both Japan and New France, there was a vast gulf between the Jesuits' appraisal of non-European converts and the non-Europeans' practice of Christianity. From the Jesuit point of view which can be seen in Jesuit propaganda contained in their correspondence, their success in transforming non-Christian people into pious Christians was never in doubt. Conversely, from the Japanese or Amerindian point of view, which can be read between the lines of the priests' observations of non-European culture, there was a strong association with non-Christian spiritual customs-including Buddhism, Shintô, and shamanism-in applying Christian ideas and in understanding the behaviour of the priests. This native perspective really meant that Christianity was only accepted and understood in terms of the deeprooted customs and beliefs of both the Japanese and Amerindians.

${ }^{74}$ Cf. Blackburn, op. cit., 105-139. 


\section{CONCLUSION: \\ THE FRENCH JESUIT MISSION REVISITED}

The aim of this study has been to seek a fresh interpretation of the Jesuit mission to New France in the light of the earlier Iberian experience in Japan. The existing historical paradigms of the French Jesuit mission to the Amerindians have been examined from a broader global standpoint well beyond North America. The time period encompasses one entire century, from the mid-sixteenth to the mid-seventeenth century. The worldwide Jesuit mission has been analysed as a series of incidents that unfolded internationally, beginning with the early mission by Father Francisco de Xavier in Japan, long before the establishment of the seventeenth-century French mission. The Christian mission in Japan provides a useful approach for revising the currently accepted historical interpretations of events in New France.

Under this new paradigm, this study has set forth several keys that lead to a cautious revisionist interpretation of the religious history of the French colony of North America. First, the missionaries began their activity by drawing on the experience of their predecessors in Japan. Second, there are certain patterns in the biases in the missionary accounts. Thus, the biases can be identified, and can be used to analyse the missions when reading the documents. Third, there was methodological continuity, rather than institutional differences, between the Franciscans and the Jesuits in their missionary policies. Fourth, in the multifaceted strategies that the missionaries developed internationally, the Jesuit approach should not be described as a single line that ran from evangelising children to converting adults. Fifth, the Amerindian réductions were not simply based on the reducciónes in Paraguay. One can find a prototype for the réductions both directly and indirectly in the Japanese Christian communities. Sixth, the Amerindian notion and practice of Christianity was beyond the priests' accounts of exemplary Christians, and thus should be discussed in terms of cultural interaction rather than in terms of religious or colonial conquest. Because of these keys, a case has been established for the revision of these aspects of the historiography of New France.

The Introduction, to begin with, has explained why an international perspective is necessary to understand the mission in New France. There was a connection between the missions in Japan and in those New 
France. There was a global web of missionary correspondence centred in Europe. In France and other countries, the reports from Japan were translated and published in numerous languages such as French, Latin and Italian, all of which the French missionaries were able to read. ${ }^{1}$ This is why the Jesuit reporters in the Jesuit narrators were familiar with the Iberian mission in Japan.

The review of literature on the Jesuit missions in the first chapter has shown the necessity for including the Iberian missions of the sixteenth century in any study of the Jesuits in the Americas. In the historiographies of both New France and Japan, there have been numerous contributions to the understanding of the Christian missions. Granted, each area of study developed independently of the other, but the French priests were never ignorant of Father Xavier and other Iberian predecessors. Father Xavier was a saint and a model for them.

Through the classification of missionary approaches, the next three chapters, two to four, have revealed epistemological problems in the historical understanding of the French Jesuit mission. These problems lie in the inherent biases of the Jesuit documents, in the evolution of multifaceted evangelistic strategies and in the creation of native Christian communities. In these three aspects, this study has found room for revisionist proposals.

The second chapter has identified the biases that ruled the missionary accounts. The clue to this identification has been analysing how the frequently repeated themes appeared in the missionary correspondence. These biases cannot be clearly identified solely through the speculative reading of the Jesuit accounts about New France. To overcome this limitation, the contrast between the written interpretations by the Iberian Jesuits of Japanese culture and actual Japanese culture has been used as a tool for identification of their biases. The biases that ruled the cross-cultural understanding of Japan were not peculiar to the Iberian Jesuits. The French missionaries failed to recognise that they might be making an equally mistaken analysis that their Iberian predecessors had made in their reports.

This study has recognised two basic characteristics of missionary biases. The first characteristic is that there were two types. One was

\footnotetext{
${ }^{1}$ One should realise that not all of the Jesuits in New France were French. Father Francis Joseph Bressani, for example, was an Italian who served for the French mission.
} 
thematic bias while the other was interpretive. The identification of these two biases has shed light on the French priests' observations of indigenous North American cultures. The second characteristic is that the interests of the Jesuit order, rather than the priests' own personal initiatives, dominated the thematic and interpretive descriptions of a non-Christian culture. The changing situations at each developmental stage of evangelistic activity generally determined the Jesuit interpretations of a non-Christian culture.

This substantial identification of European biases has exposed the interconnection between the biased cultural observations by the Iberian priests and those by the French priests. What is to be noted is that Euro-Christian readers of the missionary accounts were unable to recognise the Iberian misunderstandings of Japan and its people, since the written accounts were strictly determined by Euro-Christian biases. In the rhetoric of the missionary reports, the French reporters made epistemological mistakes similar to those made by their Iberian predecessors.

Furthermore, the analysis of the Iberian experience in Japan from a Japanese perspective has helped to confirm that the French missionaries depended on their own cultural framework to understand Amerindian customs. Fully convinced that the native beliefs were superstitions rather than a religion, they nevertheless resorted to Euro-Christian religious concepts for their interpretation of these indigenous beliefs. When the Jesuits could not understand any particular Amerindian spiritual custom, they were forced to explain it by resorting to their own version of diabolism.

The second chapter has also proposed another rhetorical limitation in these evangelistic reports. The reporters had to adjust their written expressions to suit the European readers' limited cultural and linguistic understanding. In other words, when they wrote about their experiences abroad, they had to decide what to mention and how to describe it. They interpreted their experiences much better in their own minds than in their written accounts, which of course were designed to be understood by French readers in Europe.

The identification of biases and rhetorical restrictions has revealed the pattern of the French Jesuit observations. The Jesuits described the visible aspects of native culture in their own pragmatic way. In their interpretations of non-Christian peoples, they are more restricted and distorted not only by wilful descriptive manipulation but also by the limitations of cultural differences. Their written accounts present the 
image that the missionaries expected their readers to hold about native people and their culture. Among other things, The Jesuit Relations served as tools to justify their choice of potential converts.

It is this political pragmatism that explains why the Jesuit accounts of New France are full of negotiations with influential native leaders. It was this pragmatism that drove the Jesuits to search for those with power and authority. These political elements were important to help them to figure out whom to approach first as a potential patron. Their analysis of the Amerindian social structure was directed towards the same strategic ends of locating the centres of power to be used for their own purposes.

The third chapter has explored the evolution of multifaceted strategies in order to look for a better interpretation of two established schools of thought about the New France mission. This chapter began by considering how Father Xavier devised an approach to the Japanese in the mid-sixteenth century. The chapter also illustrated how the Jesuit successors developed his evangelistic methods from that time until the mid-seventeenth century. Thus, the Jesuits in New France did not have to develop their own evangelistic approach from scratch. Instead, they built upon what they read in reports from Japan, and they could thereby improve their strategies for preaching and winning converts as well as for educating the native peoples.

Interpreting how the missionary strategies evolved over time has proposed more appropriate interpretations for two important issues. The first issue is that, in Canadian historiography, the Franciscan missionaries have been labelled cultural absolutists, and, on the other hand, the Jesuit missionaries are called cultural relativists. In Japan, however, the Franciscan policy was no different from the Jesuit policy, as far as the introduction of Euro-Christian culture is concerned. The strategies of these two religious orders in Japan have yielded another possibility for interpretation. When this flow of information from Japan to New France via Europe is taken into account, it is clear that one should adjust simplistic labels like cultural absolutism and cultural relativism, which have formed part of the Canadian interpretation.

Most methodological differences in the mission of New France were not caused by the institutional difference between the two religious orders. The difference was to be found elsewhere, between the pioneer missionaries and those who came later to the Saint Lawrence Valley and Great Lakes regions. Any detectable difference was the result of continual evolution of evangelistic strategies throughout the first half of the 
seventeenth century. The priests adjusted their missionary methods in accordance to the ever-changing cultural environment around them. This adjustment caused the evolution of missionary policies over time.

The second issue is whether the missionaries gave priority to adults or the young using one single method to convert the Amerindians, as has been claimed repeatedly in the Canadian historiography. Methodological similarities between the Iberian and French missions have demonstrated that the Jesuits, since the earliest years in Japan, had already evolved multifaceted strategies internationally when the French Jesuits began their work in North America. Converting the general adult population and educating children were two independent activities, and each had its own motive. The former was essential for creating a Christian community, while the latter was fundamentally based on the educational mandate of the Jesuit order. The Jesuit approach was not a shift from converting children to evangelising adults.

A more nuanced interpretation for this issue of conversion and education is that the Jesuit missionaries worked with a variety of approaches, with an emphasis on two basic lines. One was political diplomacy, and the other was philanthropy. The missionaries were diplomatically careful about whom to approach for their best evangelistic foundation. Philanthropy served as a tool for attracting a wide range of the population. Missionary education may be a third independent line of approach if it is regarded as part of the Jesuit principle of missionary activity. One should distinguish these plural lines of methodological evolution in the missions in order to understand the international evolution of the multifaceted methods beyond New France.

Next, in a global perspective beyond New France, the fourth chapter has reconsidered the popular idea that colonial French réductions were modelled on the Paraguayan reducciónes. The first step in this reconsideration has been to confirm that there was no definitive explanation of the origin of the Paraguayan scheme for creating Christian communities. The second step has been to find references to Japan as the goal of the mission in the Jesuit documents on Paraguay, as well as finding the Japanese legacies in the names of reducciónes. In a third step, based on these first two steps, methodological interconnection has been established between Japanese Christian villages in Hizen and the Paraguayan Christian communities. In a final step, a similar interconnection between the réductions and the reducciónes has been examined. These four stages of analysis have proposed the need to revise repeatedly-stated opinions about Amerindian Christian communities. 
From several examples of comparisons, it is true that the Laurentian réductions emulated aspects of the Paraguayan reducciónes. The Jesuits established some degree of political autonomy in the réductions. They were at least partly successful in settling the Innu and Algonquin peoples in réductions. The missionaries gained control of native community administration. They shared the same policies with their predecessors in Paraguay both in their philanthropic spirit for invalids and in their indifference to the prevention of epidemics. Nevertheless, all these approaches have turned out to have been emulations of the Iberian mission in Japan.

The fourth chapter has also shown that the réductions resembled more closely the Japanese Christian communities in several other ways. The segregation of réductions was just as incomplete as that of the Christian villages in Hizen. The missionaries both in Japan and in New France tolerated traditional clothing and made little effort to replace it with European-style garments. Both missionary groups were tolerant of indigenous dwellings for converts. More significantly the French Jesuits revived the office of dogiques from the Iberian experiments of Japanese dôjuku, a term never used in Paraguay.

Thus, the widely-held scholarly opinion concerning the prototypes for the réductions needs to be reconsidered with regard to the following two aspects. One is that the Jesuits in Paraguay did not create the idea for the reducciónes without precedent. These reducciónes were instead based on models of the Jesuit experiments in Asia, especially in Japan. Likewise, the prototype for réductions in New France has been discovered beyond Paraguay. Another aspect is that the réductions did not completely emulate the Paraguayan models. This study has shown that the design of colonial French réductions originated not only in a Paraguayan model but also directly in the Japanese Christian communities.

This international connection has turned out to be more complex. It is to the creation of Japanese Christian villages that most of the fundamental characteristics of the Laurentian réduction scheme can be traced, either directly or indirectly. The distinctive features of those réduction approaches that were obviously alien to the Paraguayan experiment, were not original to the French Jesuits. Rather, they are much more likely to have been the approaches emulated and developed directly from the successful endeavours to establish Christian villages in Japan. 
Based on the above consideration of evangelistic methods, the fifth chapter has altered the angle of perspective from one-sided missionary attempts to an interaction between priests and indigenous people. The discussion in this chapter begins by pointing to the epistemological limits of existing general approaches to the non-European practice of Christianity. The conventional focus on the degree of conversion to authentic Christianity prevented the recognition of the priests' major concerns about conversion as well as the identification of typical Christians. Nor did the conventional focus grasp the collective, rather than individual, acceptance and comprehension of the faith.

Based on this premise, the fifth chapter has discussed the Japanese response to missionary attempts, in order to identify the process by which non-European converts became Christians. In so doing, the meaning of the Jesuit evangelisation has been reconsidered in the context of non-European culture. Also, the major determinants in formulating the Japanese practice of Christianity have been sought out. Above all, the argument has revealed the nonconformity between European and non-European ideas concerning the true meaning of conversion to Christianity.

This comparative approach has been applied in order to reinvigorate and revise the existing historiographical debate on the Amerindian practice of Christianity. Up until now, the debate has been ruled by the rhetorical universe of The Jesuit Relations, and has been expressed in terms of conquest and subordination. As well, the debate was shaped by the degree of evangelical success. To revise these perspectives, this study has attempted to draw a more plausible picture of Amerindian acceptance and comprehension of the Europeans' religion.

This study makes it clear that Christianity meant several things to Amerindian converts. Christianity, with its divine grace, was the key to access to worldly benefits and social services. Christianity also replaced the traditional hereditary tie to indigenous society with a new tie only available through Christian prayers and sacraments. It worked as a social tie creating new communities in the réductions. The Christian religion was believed to provide a supernatural healing and killing power that Amerindians expected on the basis of their own non-Christian beliefs.

This study has identified one dominant factor that helps to explain the meaning of conversion. The Jesuit approach was adjusted to suit Amerindians and was the primary determinant for the acceptance and comprehension of Christianity. Non-Christian cultural compatibility 
with the new religion was only of secondary importance. The priests were adept at modifying their methods based on their understanding of the social and spiritual environment of the indigenous people. The Jesuits borrowed from Amerindian customs whatever was equivalent to Christian elements.

This Amerindian version of the faith was a result of native responses to the Jesuit mission. The indigenous people understood the tactful Jesuit preaching within the traditional framework of custom. Through the limited indigenous resources based on this emulation and on their selective emphasis on specific aspects of missionary services, the Amerindian people developed their own concepts of Christianity. In so doing, their version of Christianity proved to be beyond the scope of the rhetorical references to model proselytes in The Jesuit Relations.

Therefore, the history of Christian missions in seventeenth-century New France and the cross-cultural relations incidental to them need to be revised. The Jesuit mission in New France is not only a part of North American history but also a part of global history. This study has demonstrated that placing events of New France within an international perspective enables one to understand more accurately why and how the Jesuit missions adopted particular policies in the development of their evangelistic programme.

This thesis has also pointed out that Amerindian Christianity can be fully discussed neither in terms of evangelistic success nor in terms of cultural transformation. Christian conversion was a complex process of interaction between two cultural groups. One side included those who attempted to propagate the religion extensively and effectively. The other included those who tried to accept and integrate it into a non-Christian culture in a comprehensible manner.

This diachronic comparison of the missions may be just one example of possible perspectives for better recognition of a past that may have something to tell us today about cultural transfer. The comparison is also an important key to improved understanding of the missionary experience in New France. Furthermore, in this new historical perspective on New France, there is much room for further development. 


\section{BIBLIOGRAPHY OF WORKS CITED}

[To avoid confusion in this bibliography, the order of all the Japanese names is the same as that of European names, whether published in Japanese or in any Europeanlanguage. Namely a family name follows a personal name: e.g. 'Matsuda, Kiichi' in the entry and 'Kiichi Matsuda' in other areas of the publication data.]

\section{A. Contemporary Sources (InCluding later publications)}

Bartoli, Daniello, SJ. Dell'Historia della Compagnia di Giesu: Il Giappone; Seconda parte dell'Asia. Rome, 1660.

- Giappone: Istoria della Compagnia di Gesu. A cura di Nino Majarell, prefazione di G. S. S. I. 1660. Milano: Spirali, 1985.

Biggar, H. P., ed. The Works of Samuel de Champlain. 6 vols. Toronto: The Champlain Society, 1922-36.

Campeau, Lucien, SJ. Monumenta Nove Francice. 8 vols. A series of Monumenta Historica Societatis Iesus. Roma: Monumenta Historica S. I.; Québec: les Presses de l'Université Laval, 1967-2003.

Charlevoix, Pierre-François-Xavier de, SJ. Histoire de l'établissement, des progrès et de la décadence du christianisme dans l'empire du Japon, où l'on voit les differentes révolutions qui ont agité cette Monarchie pendant plus d'un siècle. 2 vols. Rouen: Guillaume Behourt; Jacques Joseph le Boullenger; Pierre le Boucher, 1715.

- Histoire et description générale de la Nouvelle France, avec le journal historique d'un voyage fait par ordre du roi dans l'Amérique septentrionale. 3 vols. Paris: Didot, 1744.

- Histoire et description du Japon. 1715. $4^{\mathrm{me}}$ Édition. Tours: $\mathrm{A}^{\mathrm{d}}$ Mame et $\mathrm{C}^{\mathrm{ie}}$, 1844

Costelloe, M. Joseph, SJ, trans. The Letters and Instructions of Francis Xavier. St. Louis, Missouri: The Institute of Jesuit Sources, 1992.

Orig. Georg Schurhammer, SJ, \& J. Wicki, SJ, eds. Epistole S. Francisci Xavierii aliaque eius scripta. 2 tomus. Romae: Monumenta Historica Soc. Jesu, 1944-45.

Farrell, Allan P., SJ, trans. The Jesuit Ratio Studiorum of 1599. Washington, D. C.: Conference of Major Superiors of Jesuits, 1970.

Fenton, William N., ed., \& Elizabeth L Moore, trans. Customs of the American Indians Compared with the Customs of Primitive Times. By Joseph-François Lafitau, SJ. 2 vols. Toronto: Champlain Society, 1974.

Fróis, Luís, SJ. Historia de Japam. [See Wicki, José, SJ, ed. Historia de Japam.]

Grant, W. L., ed. Voyages of Samuel de Champlain. By Samuel de Champlain. Original Narratives of Early American History. New York: Barnes and Noble, 1907.

Guzmán, Luis de, SJ. Historia de las Missiones de la Compañía de Jesus. 1601. [Republished in 1891]

Kôno Yoshinori, SJ, trans. Sei Furanshisuko Zabieru zen shokan. By Francisco de Xavier, SJ. Tokyo: Heibon-sha, 1985.

Orig. Georg Schurhammer, SJ, \& J. Wicki, SJ, eds. Epistoloe S. Francisci Xavierii aliaque eius scripta. 2 tomus. Romae: Monumenta Historica Soc. Jesu, 1944-45.

Lafitau, Joseph-François, SJ. Moeurs des sauvages amériquains, comparées aux moeurs des premiers temps. 2 tomes. Paris: Saugrain l'ainé \& Charles Estienne Hochereau, 1724 .

Le Clercq, Chrestien. Premier établissement de la foy dans la Nouvelle France. 2 vols. Paris: Auroy, 1691. 
Matsuda, Kiichi, Tadashi Sakuma \& Hiroo Chikamatsu, eds. Nippon junsatsuki. By Valignano, Alejandro, SJ. 1965. Toyo Bunko 229. Tokyo: Heibon-sha, 1973.

Orig. Bibliotheca da Ajuda. Cód. 49-IV-56. ff. 55-114v., 116-145v.

Matsuda, Kiichi et al, eds. Jûroku-shichi seiki Iezusukai Nippon hôkokushû. 3 series. 17 vols. Kyoto: Dôhô-sha, 1987-2000.

Matsuda, Kiichi \& Engelbert Jorißen, eds. Frois no Nippon oboegaki: Nippon to yôroppa no fûsh û no chigai. By Luis Frois, SJ. Tokyo: Chuôkôron-sha, 1983.

Based on Bibliotheca de la Real Academia de la Historia (Madrid), 9-7236, ff. 247-279.

Matsuda, Kiichi \& Momota Kawasaki, trans. Furoisu Nipponshi. By Luis Frois, SJ. Tokyo: Chuôkôron-sha, 1977-80.

Orig. Historia de Iapam. Based on the following manuscripts: (1) Primeira Parte da Historia de Iapam. Bibliotheca da Ajuda. Cód. 49-V-54. (2) Segunda Parte da Historia de Iapam. Lisboa: Arquivo Histórico Ultramarino. Cód. 1659. (3) Apparatos para a Historia Ecclesiastica do Bispado de Macau. Lisboa: Biblioteca Nacional. Cód. 11098. (4) Apparatos para a Historia Ecclesiastica do Bispado de Iapam. Bibliothec da Ajuda. Cód. 49-IV-57.

Montoya, Antonio Ruiz de. The Spiritual Conquest Accomplished by the Religious of the Society of Jesus in the Province of Paraguay, Paraná, Uruguay, and Tape. 1639. Trans. C. J. McNaspy, SJ, et al. St. Louis: The Institute of the Jesuit Sources, 1993.

Murakami, Naojirô, ed. Diary of Richard Cocks, Cape-Merchant in the English Factory in Japan, 1615-1622, with Correspondence. Tokyo: Sankô-sha, 1899.

—-, trans. Iezusukaishi Nippon tsûshin. Ed. Yanagiya Takeo. 2 vols. Tokyo: Yûshô-dô, 1968-69.

— - trans. Iezusukai Nippon nenpô. 2 vols. Tokyo: Yûshô-dô, 1969.

—

Murakami, Naojirô, \& Kengo Murakawa, eds. Letters Written by English Residents in Japan, 1611-1623. Tokyo, 1900.

Okada, Akio, trans. Nichi-ô bunka hikaku. By Luis Frois. Daikôkaijidai sôsho XI. Tokyo: Iwanami Shoten, 1965.

Orig. Josef Franz Schütte, SJ, trans. Kulturgegensätze Europa-Japan: Tratado em que se contem muito susinta e abreviadamente algumas contradições e diferenças de custumes antre a gente de Europa e esta provincia de Japão. By Luis Frois, SJ. Tokyo, 1955.

_ - trans. Yôroppa bunka to Nippon bunka. Tokyo: Iwanami shoten, 1991.

Orig. Josef Franz Schütte, SJ, trans. Kulturgegensätze Europa-Japan: Tratado em que se contem muito susinta e abreviadamente algumas contradiçôes e diferenças de custumes antre a gente de Europa e esta provincia de Japão. By Luis Frois, SJ. Tokyo, 1955.

Okamoto, Yoshitomo, trans. Kyushu sankô ken'ô shisetsu kôki. By Luis Frois. Tokyo: Yûshô-dô, 1942.

Orig. Okamoto Yoshitomo et al, eds. La Première Ambassade du Japon en Europe, 1582-1592. 1942.

Okamoto, Yoshitomo, Henri Bernard, SJ, et João do Amaral Abranches, eds. La première Ambassade du Japon en Europe, 1582-1592. Monumenta Nipponica Monographs. Tokyo: Université Sophia, 1942.

Okamoto, Yoshitomo \& João do Amaral Abranches Pinto, eds. Segunda parte da Historia de Japam que trata das couzas, que socedarão nesta V. Provincia da Hera de 1578 por diante, começãdo pela conversão del rey de Bungo (1578-1582). Tokyo: Edição da Sociedade Luso-Japonesa [or Nippo Kyokai], 1938.

Padberg, John W., SJ, ed. The Constitutions of the Society of Jesus and Their Complementary Norms. Saint Louis: The Institute of Jesuit Sources, 1996.

Ravignani, Emilio E. \& Carlos Leonhardt, SJ, eds. Iglesia: Cartas annuas de la Provincia del Paraguay, Chile y Tucumán, de la Compañia de Jesús (1609-1614). Vol. XIX of Documentos para la historia argentina. Buenos Aires: Casa Jacobo Peuser, 1927. 
Ravignani, Emilio E. \& Carlos Leonhardt, SJ, eds. Iglesia: Cartas annuas de la Provincia del Paraguay, Chile y Tucumán, de la Compañía de Jesús (1615-1637). Vol. XX of Documentos para la historia argentina. Buenos Aires: Casa Jacobo Peuser, 1929.

Rodriguez-Tçuzu, João, SJ. Nippon kyôkaishi. Ed. \& Trans. Yasuhiko Sano et al. Daikôkaijidai sôsho IX \& X. Tokyo: Iwanami shoten, 1967.

Orig. Historia da Igreja do Japão.

Sagard, Gabriel. Le grand voyage du pays des Hurons situé en l'Amérique vers la Mer douce, ès derniers confins de la nouvelle France, dite Canada. Paris, 1632.

Schilling, Doroteo [Dorotheus] \& Fidel de Lejarza, eds. 'Relación del Reino de Nippon'. Archivo Ibero-Americano 36 (1933): 481-531; 37 (1934): 5-48, 259-75, 392-434, 493-554; and 38 (1935): 103-30, 216-39, \& 384-417.

Schurhammer, G, SJ, \& E. A. Voretzch, SJ, trans. Die Geschichte Japans (1549-1578). By Luis Frois, SJ. Leipzig: Verlag der Asia Major, 1926.

Thwaites, Reuben Gold, et al, eds. The Jesuit Relations and Allied Documents: Travels and Explorations of the Jesuit Missionaries in New France, 1610-1791. 73 vols. Cleveland: Burrows Brothers, 1896-1901.

Tokyo daigaku shiryô hensanjo, ed. Nippon kankei kaigai shiryô: Iezusukai Nippon shokansh û. 6 vols. Tokyo: Tokyo daigaku shiryô hensanjo, 1990-.

Wicki, José, SJ, ed. Historia de Japam. By Luís Fróis, SJ. 5 vols. Lisboa: Biblioteca nacional de Lisboa, 1976-84.

Wolfe, Pierre, ed. The Spiritual Exercises of Saint Ignatius: A New Translation from the Authorized Latin Text. Liguori, Missouri: Triumph, 1997.

Wrong, George M., ed. The Long Journey to the Country of the Hurons. By Gabriel Sagard. Toronto: The Champlain Society, 1939.

\section{B. Post-missionary Sources}

\section{Western-language Sources}

Abé, Takao. 'A Japanese Perspective on the Jesuits in New France'. Actes du vingtième colloque de la société d'histoire coloniale française, Cleveland, Ohio, May 1994. Ontario: Mothersill Printing, 1996. 14-26.

- 'What Determined the Content of Missionary Reports? The Jesuit Relations Compared with the Iberian Jesuit Accounts'. French Colonial History 3: 69-82. East Lansing: Michigan State University Press, 2002.

- 'The Seventeenth-Century Jesuit Missionary Reports on Hokkaido', Journal of Asian History 39 (2005): 111-28.

Abou, Sélim. The Jesuit 'Republic' of the Guaranis (1609-1768) and Its Heritage. New York: The Crossroad Publishing Company, 1997.

Alden, Dauril. The Making of an Empire: The Society of Jesus in Portugal, Its Empire, and Beyond, 1540-1750. Stanford, CA: Stanford University Press, 1996.

A Member of the Ursuline Community. Life of Madame de la Peltrie (Magdalen de Chauvigny), Foundress of the Ursuline Convent, Quebec. New York: Edward Duignan \& Brother, 1859.

- Glimpse of the Monastery: A Brief Sketch of the History of the Ursulines of Quebec during the Lifetime of Venerable Mother Mary of the Incarnation. Quebec: C. Darveau, 1872.

Anderson, Karen. Chain Her by One Foot: The Subjugation of Women in SeventeenthCentury New France. London \& New York: Routledge, 1991.

Axtell, James. The Invasion Within. New York \& Oxford: Oxford University Press, 1985.

Bailey, Alfred Goldsworthy. 'The Significance of the Identity and Disappearance of Laurentian Iroquois'. Transactions of the Royal Society of Canada, 3rd series, section II, 28 (1933): 97-108. 
The Conflict of European and Eastern Algonkian Culture, 1504-1700: A Study in Canadian Civilization. Saint John: New Brunswick Museum, 1937.

- 1938. 'Social Revolution in Early Eastern Canada'. The Canadian Historical Review 19: 264-76.

- The Conflict of European and Eastern Algonkian Culture, 1504-1700: A Study in Canadian Civilization. 1937. 2nd ed. Toronto: University of Toronto Press, 1969

Blackburn, Carole. Harvest of Souls: The Jesuit mission and Colonialism in North America, 1632-1650. Montreal \& Kingston: McGill-Queen's University Press, 2000.

Blanchard, David S. 'To the Other Side of the Sky: Catholicism at Kahnawake, 16671700'. Anthropologica 24 (1982): 77-102.

Boxer, C. R. [Charles Ralph]. The Christian Century in Japan, 1549-1650. Berkeley \& Los Angeles: University of California Press; London: Cambridge University Press, 1951.

[The 2nd edition, a corrected reprint, was published in 1967.]

Bucko, Raymond A. 'Bartholomé de Las Casas, 1474-1566'. Early Encounters in North America: Biography. N.p.: Alexander Street Press, L. L. C.; and the University of Chicago, 2004.

www.alexanderstreet2.com/EENALive/bios/A6919BIO.html, 11 December 2005.

Bumsted, J. M. 'William Smith Jr. and The History of Canada'. Loyalist Historians. Vol. I of Colonial Legacy. Ed. Lawrence H. Leder. New York: Harper \& Row, 1971. 182-201.

—. 'William Smith'. Dictionary of Canadian Biography VII. 1988. 816-19.

Campbell, Thomas J., SJ. Pioneer Priests of North America, 1642-1710. 3 vols. New York: The American Press, 1908-11.

- Out of the Grave: The Discovery of Fort St. Charles in 1908. St. Boniface: Manitoba, 1915.

- The Jesuits, 1534-1921: A History of the Society of Jesus from Its Foundation to the Present Time. 2 vols. New York: The Encyclopedia Press, 1921.

- The Martyrs of the Mohawk. New York: Apostleship of Prayer, 1926.

Campeau, Lucien, SJ. La première mission d'Acadie (1602-1616). Vol. XCVI of Monumenta Historica Societatis Iesu Roma: Monumenta Historica S. I.; Québec: les Presses de l'Université Laval, 1967.

—. La première mission des Jésuites en Nouvelle-France, 1611-1613. Montréal: Bellarmin, 1972.

—. La mission des Jésuites chez les Hurons, 1634-1650. Vol. XLVI of Bibliotheca Instituti Historici S. I. Montréal: Bellarmin; Roma: Instititum Historicum S. I., 1987.

- Biographical Dictionary for the Jesuit Missions in Acadia and New France: 16021654. Trans. William Lonc and George Topp, SJ. N.p.: Wiiliam Lonc, 2001.

—. 'Fr. Jacques de la Foyer'. In Campeau. 2001. 227-28.

—. 'Henri de Lévis'. In Campeau. 2001. 266-69.

Caraman, Philip. The Lost Paradise: An Account of the Jesuits in Paraguay, 1607-1768. London: Sedgwick \& Jackson, 1975.

Cary, Otis. A History of Christianity in Japan: Roman Catholic, Greek Orthodox, and Protestant Missions. 2 vols. New York: Fleming H. Revell, 1909.

[Republished in one book by Tuttle at Rutland, Vermont, \& Tokyo, Japan, in $1976]$

Charest, Paul. 'Les Montagnais d'autrefois, les Innus d'aujourd'hui'. Cap-auxDiamants 85 (printemps 2006): 10-15.

Christian, William A. Local Religion in Sixteenth-Century Spain. Princeton, NJ: Princeton UP, 1981.

Conwell, Joseph F., SJ. Impelling Spirit: Revisiting a Founding Experience: 1539, Ignatius and His Companions. Chicago: Loyola Press, 1997.

Côté, Jean. The Donnés in Huronia. Trans. William Lonc, SJ, \& George Topp, SJ. N.P.: William Lonc, 2001. [Orig. a thesis in 1955 for the University of Montreal under the title of 'L'institution des Donnés à Sainte-Marie-des Hurons']. 
Cushner, Nicholas P. Why Have You Come Here?: The Jesuits and the First Evangelization of Native America. New York: Oxford University Press, 2006.

Delplace, Louis, SJ. Le catholicisme au Japon. 2 vols. Maline, Bruxelles, 1909-10.

Deslandres, Dominique. Croire et faire croire: Les missions françaises au XVII ${ }^{e}$ siècle (1600-1650). Paris: Fayard, 2003.

Dickason, Olive Patricia. The Myth of the Savage and the Beginnings of French Colonialism. Edmonton: University of Alberta Press, 1984.

- Canada's First Nations: A History of Founding Peoples from Earliest Times. Toronto: McClelland and Stewart, 1992.

Dumas, G. M. 'Georges le Baillif'. Dictionary of Canadian Biography Online. Library and Archives Canada. www.biographi.ca, 14 August 2005.

_. 'Guillaume Galleran'. In Dumas.

—. 'Gervais Mohier'. In Dumas.

—. 'Irénée Piat'. In Dumas.

—. 'Nicolas Viel'. In Dumas.

_. 'Pacifique Duplessis', In Dumas.

—. 'Paul Huet'. In Dumas.

Elison, George. Deus Destroyed: The Image of Christianity in Early Modern Japan. Harvard East Asian Monographs 141. Cambridge, MA: Council on East Asian Studies, Harvard University, 1973. Distributed by Harvard University Press, Cambridge and London.

Elison, George \& Bardwell L. Smith, eds. Warlords, Artists, and Commoners: Japan in the Sixteenth Century. Honolulu: University of Hawaii Press, 1981.

Emerson, J. N. 1962. 'Cahiagué 1961'. Ontario History 54: 136-137.

Faillon, Étienne-Michel. Histoire de la colonie française en Canada. 3 tomes. Villemarie: Bibliothèque Paroissiale; Paris: Poupart-Davyl, 1865-66.

Ferland, Jean-Baptiste. Cours d'histoire du Canada. 2 parties. Québec: Augustin Côté, 1861-65.

Fujita, Neil S. Japan's Encounter with Christianity: The Catholic Mission in Pre-modern Japan. New York \& Mahwah, NJ: Paulist Press, 1991.

_. "Conic" Christianity and "Donut" Japan'. Missiology: An International Review 22 (1994): 43-53. American Society of Missiology.

Galpern, Alan N. The Religions of the People in Sixteenth-Century Champagne. Harvard Historical Studies 92. Cambridge, Mass.: Harvard UP, 1976.

Garneau, François Xavier. History of Canada from the Time of Its first Discovery till the Union Year 1880-41. 1860. 2nd ed. Trans. \& ed. Andrew Bell. 2 vols. Montréal: John Lovell, 1862.

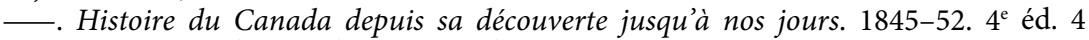
tomes. Montréal: Beauchemin \& Valois, 1882.

Gingras, Frédéric. 'Denis Jamet'. Dictionary of Canadian Biography Online Library and Archives Canada. www.biographi.ca, 14 August 2005.

—. 'Guillaume Poulain'. In Gingras.

—. 'Jean Dolbeau'. In Gingras.

—. 'Joseph le Caron'. In Gingras.

Goddard, Peter A. 'The Devil in New France: Jesuit Demonology, 1611-50'. The Canadian Historical Review 78 (1997): 40-62.

Graham, R. B. Cunninghame. A Vanished Arcadia: Being Some Account of the Jesuits in Paraguay, 1607 to 1767. London: William Heinemann, 1901.

Grant, John Webster. Moon of Wintertime: Missionaries and the Indians of Canada in Encounter since 1534. Toronto: University of Toronto Press, 1984.

Gravier, Gabriel. Vie de Samuel de Champlain: Fondateur de la Nouvelle-France (1567-1635). Paris: Librarie orientale \& américaine, 1900.

Greer, Allan. Mohawk Saint: Catherine Tekakwitha and the Jesuits. New York: Oxford University Press, 2005. 
Haas, Hans. Geschichte des Christentums in Japan. 2 vols. Tokio [Tokyo]: Rikkyo Gakuin Press, 1902-04.

—. Die Sekten des Japanischen Buddhismus: Eine Religionswissenschaftlich Studie. 2. Flugschriftenreihe des allgemeinen evangelisch-protestantischen Missionvereins $\mathrm{H}$. [Heft] 6. Heidelberg, 1905.

- 'Die Religion der Japaner; 2. Der Buddhismus'. Die orientaliscen Religionen. Ed. von Edvard Lehman \& A. Erman. Berlin \& Leipzig: B. G. Tübner, 1906. 221-54.

—. Japans Zukunftsreligion. 2. Aufl. Berlin: K. Curtis, 1907.

—, ed. \& trans. 'Amida Buddha unsere Zuflucht'; urkunden zum verständnis des Japanischen Sukhavati-Buddhismus. Göttingen: Vandenhöck \& Ruprecht; Leipzip: J. C. Hinrichs, 1910.

- Bibliographie zur Frage nach den Wechselbeziehungen zwischen Buddhismus und Christentum. Leipzig: J. C. Hinrichs, 1922.

- Buddha in der abendländlichen Legende. Nr. 9 von Veröffentlichungen des Forchungsinstitut für verleichende Religionsgeschichte, Leipzig Universität. Leipzig: J. C. Hinrichs, 1922.

. Die Ainu und ihre Religion. Bilderatlas zur Religionsgeschichte 8. Leipzig: A. Deichert, 1925.

Harvey, L. P. Muslims in Spain, 1500 to 1614. Chicago \& London: University of Chicago Press, 2005.

Haubert, Maxime. La vie quotidienne des Indiens et des Jésuites du Paraguay au temps des missions. N.p. [Paris]: Librairie Hachette, 1967.

Heidenreich, Conrad E. and Arthur J. Ray. The Early Fur Trades: A Study in Cultural Interaction. Toronto: McClelland and Stewart, 1976.

Heidenreich, Conrad E. 'The Indian Occupance (sic) of Huronia, 1600-1650'. Canada's Changing Geography. Ed. by R. Louis Gentilcore. Scarborough: Prentice Hall of Canada, 1967. 15-29.

- Huronia: A History and Geography of the Huron Indians, 1600-1650. Toronto: McClelland and Stewart, 1971.

Huonder, A. 'Reductions of Paraguay'. Vol. 12 of The Catholic Encyclopedia. Online Edition. N.p.: New Advent, 2005. www.newadvent.org/cathen/12688b.htm, 23 November 2005.

Jackson, Robert H. 'Jesuit Frontiers: A Comparison of the Development of the Two Missions in Baja California and Paraguay'. San Jose de Comondu, 1708-1808. www.timsbaja.com/rjackson/0200703/loretomissionscomparison.html, 22 December 2005.

Jackson, Robert H. \& Edward Castillo. Indians, Franciscans, and Spanish Colonization: The Impact of the Missionary System on California Indians. Albuquerque: University of New Mexico Press, 1995.

Jaenen, Cornelius J. 'Amerindian Views of French Culture in the Seventeenth Century'. The Canadian Historical Review 55 (1974): 261-91.

- Friend and Foe: Aspects of the French-Amerindian Cultural Contact in the Sixteenth and Seventeenth Centuries. Toronto: McClelland and Stewart, 1976.

- The Role of the Church in New France. The Frontenac Library 7. Toronto: McGraw-Hill Ryerson, 1976.

—. 'Problems of Assimilation in New France, 1603-1645'. Canadian History before Confederation. 1972. 2nd ed. Georgetown, Ontario: Irwin-Dorsey, 1979. 40-58. Orig. French Historical Studies 4 (1966): 265-89.

- The French Relationship with the Native Peoples of New France and Acadia. Ottawa: Canadian Government Publishing Centre, 1984.

- 'The Meeting of the French and Amerindian in the Seventeenth Century'. Vol. II of Interpreting Canada's Past. Ed. J. M. Bumsted. 2 vols. Toronto: Oxford University Press, 1986. Orig. Revue de l'Université d'Ottawa 43 (1973): 128-44. 
'Education for Francisation: the Case of New France in the Seventeenth Century'. The Legacy. Vol. I of Indian Education in Canada. Eds. Jean Barman, Yvonne Hébert \& Don McCaskill. Vancouver, University of British Columbia Press, 1986.

Jenness, Diamond. The Indians of Canada. 7th ed. 1932. Ottawa: National Museum of Canada, 1977.

Jury, Wilfrid \& Elsie McLeod Jury. Sainte-Marie among the Hurons. Toronto: Oxford University Press, 1954.

- Saint Louis: Huron Indian Village and Jesuit Mission Site. Bulletin no. 10, Museum of Indian Archaeology, The University of Western Ontario. London, Ontario, 1955

Kennedy, John Hopkins. Jesuit and Savage in New France. New Haven: Yale University Press, 1950.

Kidd, Kenneth Earl. The Excavation of Sainte-Marie I. Toronto: University of Toronto Press, 1949.

Kinietz, W. Vernon. The Indians of the Western Great Lakes, 1615-1760. 1940. N.p.: Ann Arbor, 1965. First published by University of Michigan Press \& by Rexdale: John Wiley \& Sons.

Koebel, W. H. In Jesuit Land: The Jesuit Missions of Paraguay. London: Stanley Paul \& Co., 1912.

Latourelle, René, SJ. Jean de Brébeuf's Writings: A Study. Trans. William Lonc, SJ \& George Topp, SJ. N.p.: William Lonc, 2001.

$\mathrm{Li}$, Shenwen. Stratégies missionnaires des jésuites français en Nouvelle-France et en Chine au XVII siècle. Saint-Nicolas, Québec: les Presses de l'Université Laval; Paris: Harmattan, 2001.

Laflèche, Guy. 'Les Jésuites de la Nouvelle-France et le mythe de leurs martyrs'. Les Jésuites parmi les hommes aux XVI et XVII siècles: Actes du Colloque de Clermont-Ferrand (avril 1985). Ed. G. et G. Demerson, B. Dompnier et A. Regond. N.p. (France) : Associations des Publications de la Faculté des Lettres et Sciences Humaines de Clermont-Ferrand, 1987. Pp. 35-45.

Latta, Martha A. 'Identification of the 17th century French Missions in Eastern Huronia'. Journal of Canadian Archaeology 9 (1985): 147-71.

Laures, Johannes, SJ. The Catholic Church in Japan: A Short History. Tokyo: Tuttle, 1954.

—. Die Geschichte der Katholischen Kirche in Japan. Kaldenkirchen: Steyler, 1956.

- Kirishitan Bunko: A Manual of Books and Documents on the Early Christian Missions in Japan. 1940. Enlarged edition. Tokyo: Sophia University, 1957.

MacNaspy, C. J., SJ. Lost Cities of Paraguay: Art and Architecture of the Jesuit Reductions, 1607-1767. Chicago: Loyola University Press, 1982.

Magnuson, Roger. Education in New France. Montreal \& Kingston: McGill-Queen's University Press, 1992.

Mali, Anya. 'Strange Encounters: Missionary Activity and Mystical Thought in Seventeenth Century New France'. History of European Ideas 22 (1996): 67-92.

Martin, A. Lynn. The Jesuit Mind: The Mentality of an Elite in Early Modern France. Ithaca \& London: Cornell University Press, 1988.

McIlwraith, T. F., et al. 'Archaeological Work in Huronia'. The Canadian Historical Review 27 (1946): 394-401.

McInnis, Edgar. Canada: A Political and Social History. 1947. Rev. ed. New York: Holt, Rinehart and Winston, 1959.

M'Mullen [McMullen], John. The History of Canada from Its First Discovery to the Present Time. Brockville, C. W.: J. M’Mullen, 1855.

Monet, J. 'Philibert Noyrot'. Dictionary of Canadian Biography Online. National Archives of Canada and National Library of Canada. University of Toronto \& Université Laval, 2000.

http://www.biographi.ca/EN/, 14 August 2005. 
Moogk, Peter N. La Nouvelle France: The Making of French Canada-A Cultural History. East Lansing: Michigan State University Press, 2000.

Moran, J. F. The Japanese and the Jesuits: Alessandro Valignano in Sixteenth-Century Japan. London: Routledge, 1993.

Morgan, Lewis Henry. League of the Ho-de'-no-sau-nee, Iroquois. Rochester: Sage \& Brother; New York: Mark H. Newman; Boston: Gould \& Lincoln, 1851.

- League of the Iroquois. 1851, as League of the Ho-de'-no-sau-nee, Iroquois. Reissue edition. A Citadel Press Book. New York: Carol Publishing Group, 1993.

Murdoch, James \& Isoo Yamagata. A History of Japan during the Century of Early Foreign Intercourse (1542-1651). Kobe: Kobe Chronicle, 1903.

[included later in the three volumes of A History of Japan]

- A History of Japan. Vol. I: From the Origins to the Arrival of the Portuguese in 1542. Yokohama: Kelly \& Walsh, 1910.

- A History of Japan. Vol. III: The Tokugawa Epoch (1652-1868). Rev. \& ed. Joseph H. Longford. London: K. Paul, Trench, Trübner, 1926.

Okamoto, Yoshitomo, ed. El Nippon y Philipinas sus Relaciones Historicos. Tokyo: Japan Times, 1945.

Orr, R. B. 'The Hurons'. 33rd Annual Archaeological Report 1921-22. Appendix to the Report of the Minister of Education, Ontario. Toronto, 1922. 9-23.

Pagès, Léon. Histoire des vingt-six martyrs japonais dont la canonisation doit avoir lieu à Rome, le jour de la Pentécôte 1862. Paris: Benjamin Duprat, 1862.

- Histoire de la religion chrétienne au Japon depuis 1598 jusqu'à 1651. 2 vols. Paris: Charles Douniol, 1869-70.

- La persécution des chrétiens au Japon et l'ambassade japonaise en Europe. Paris, 1873.

- La déportation et l'abandon des morts: Cimètiere de Mery. Paris, 1875.

_ - 'Cerqueira, Conference Held by the Bishop Cerqueira on the Subject of Slaves Bought or hired and transported out of Japan, in September 1598, extracted from the Archives of the Academy of History in Madrid by L. Pagès'. Japan Weekly Chronicle 29 Jan. 1902: 83-85.

Parkman, Francis. The Jesuits in North America in the Seventeenth Century. 1867. France and England in North America 2. Williamstown, Massachusetts: Corner House, 1970.

Poole, Stafford. 'Iberian Catholicism Comes to the Americas'. Part I of Christianity Comes to the Americas, 1492-1776. By Charles H. Lippy, Robert Choquette \& Stafford Poole. New York: Paragon House, 1992.

Popham, R. E. 'Late Huron Occupations of Ontario: An Archaeological Survey of Innisfil Township'. Ontario History 42 (1950): 81-90.

Principe, Charles. 'Les Jésuites missionnaires auprès des Amérindiens du Canada'. G. Demerson et al., Les Jésuites parmi les hommes aux XVI et XVII siècles. Association des Publications de la Faculté des Lettres et Science Humaines de ClermontFerrand, 1987. 309-20.

Rochemonteix, Camille de, SJ. Les Jésuites et la Nouvelle-France au XVII siècle. 3 tomes. Paris: Letouzey et Ané, 1895-96.

Ross, Andrew C. A Vision Betrayed: The Jesuits in Japan and in China, 1542-1742. Edinburgh: Edinburgh University Press, 1994.

Roy, Joseph Edmond. M. de Montmagny: Extrait de la Nouvelle-France. Québec: L'Événement, 1906.

Schilling, Dorotheus, OFM. 'Neue Funde zur História de Japão von Luis Frois S. J.' Zeitschrift für Missionswissenschaft 23 (1933): 337-43.

Schütte, Josef [or Joseph] Franz, SJ. Valignanos Missionsgrundsätze für Japan. 2 parts. Roma: Edizioni de Storia E Letteratura, 1951-58.

-. Introductio ad Historiam Societatis Jesu in Japonia, 1549-1650, ac Prœmium ad Catalogos Japonice Edendos ad Edenda Societatis Jesu Monumenta Historica Japonioe Proyloum. Romæ: Institutum Historicum Soc. Jesu, 1968. 
- Valignano's Mission Principles for Japan. 2 parts. St. Louis: The Institute of Jesuit Sources, 1980.

Simard, Jean-Jacques. La Réduction: L'autochtone inventé et les Amérindiens d'aujourd'hui. Sillery: Septentrion, 2003.

Sioui, George E. Les Hurons-Wendats: Une civilisation méconnue. Sainte-Foy, Québec: Les Presses de l'Université Laval, 1994.

- Huron-Wendat: The Heritage of the Circle. Vancouver \& Toronto: University of British Columbia Press; \& East Lansing: Michigan State University Press, 1999.

Smith, William. History of Canada; from Its First Discovery to the Year 1791. 2 vols. Québec: John Neilson, 1815.

The first volume has a slightly different title of History of Canada; from Its First Discovery till the Peace of 1763.

Steckley, John. 'The Clans and Phratries of the Huron'. Ontario Archoeology 37 (1982): 29-34.

Sulte, Benjamin. Histoire de la ville des Trois-Rivières et de ses environs. Montréal: Eusèbe Sénécal, 1870.

- Histoire des Canadiens-français, 1608-1880. 8 vols. Montréal: Wilson, 1882-84.

_. La guerre des Iroquois, 1600-1653. Ottawa: J. Durie; Toronto: Copp-Clark, 1897.

Tooker, Elizabeth. An Ethnography of the Huron Indians, 1615-1649. Bureau of American Ethnology Bulletin 190. Washington, D.C.: Bureau of American Ethnology (U.S. Government Printing Office), 1964.

- 'Northern Iroquoian Sociopolitical Organization'. American Anthropologist 72 (1970): 90-97.

—. An Ethnography of the Huron Indians, 1615-1649. 1964. Syracuse, New York: Syracuse University Press, 1991.

Trigger, Bruce G. The Huron: Farmers of the North. Case Studies in Cultural Anthropology. New York: Holt, 1969.

. The Children of Aataentsic: A History of the Huron People to 1660. Kingston \& Montreal: McGill-Queen's University Press, 1976.

- Natives and Newcomers: Canada's 'Heroic Age' Reconsidered. Kingston \& Montreal: McGill-Queen's University Press, 1985.

- The Huron: Farmers of the North. Toronto: University of Toronto Press, 1990.

Trudel, Marcel. Histoire de la Nouvelle-France. 3 tomes. Montréal \& Paris: Fides, 1963-83. Vol. III'.

—. 'Samuel de Champlain'. Dictionary of Canadian Biography Online. National Archives of Canada and National Library of Canada. University of Toronto \& Université Laval, 2000.

http://www.biographi.ca/EN/, 14 August 2005.

Turnbull, Stephen. The Kakure Kirishitan of Japan. Richmond, Surrey, UK: Japan Library, 1998.

Vincent, Marguerite Tehariolina. La nation huronne: son histoire, sa culture, son esprit. Avec la collaboration de Pierre H. Savignac. Québec: Éditions du Pelican, 1984.

Whelan, Christal. 'Loss of the Signified among the Kakure Kirishitan'. Japanese Religions 19 (1994): 82-103

Wright, J. V. 'The Middleport Horizon'. Anthropologica 2 (1960): 113-20.

- The Ontario Iroquois Tradition. National Museum of Canada Bulletin No. 210 Anthropological Series No. 75. Ottawa: Queen's Printer, 1966.

Wrong, George M. 'Introduction'. The Long Journey to the Country of the Hurons. 1939. xiii-xl.

\section{Japanese-language Sources}

Anesaki, Masaharu. Kirishitan shûmon no hakugai to senpuku. Tokyo: Dôbun-kan, 1925. 
Kirishitan kinsei no shûmatsu. Tokyo: Dôbun-kan, 1926.

—. Kirishitan dendo no kôhai. Tokyo: Dôbun-kan, 1930.

—. Kirishitan hakugaishichû no jinbutsu jiseki. Tokyo: Dôbun-kan, 1930.

—. Kirishitan shûkyô bungaku. Tokyo: Dôbun-kan, 1932.

Cooper, Michael. Tsûji Rodorigesu. Trans. Matsumoto Tama. Tokyo: Hara shobô, 1991.

Originally, Rodrigues the Interpreter: An Early Jesuit in Japan and China. New York: John Weatherhill, 1974.

Ebisawa, Arimichi. Nippon kirishitanshi. Tokyo: Hanawa shobô, 1966.

- Kirishitan no dan'atsu to teikô. Tokyo: Yûzan-kaku, 1981.

Ebisawa, Arimichi \& Kiichi Matsuda. Porutogaru evora shinshutsu byôbu monjo no kenkyû. Tokyo: Natsume-sha, 1963.

Gonoi, Takashi. 'Kirishitan jidai no kanbô ni tsuite'. Kirishitan kenkyû 19 (1979): 239-62.

- Nippon kirisutokyôshi. Tokyo: Yoshikawa kôbun-kan, 1990.

—. Tokugawa shoki kirishitan kenkyû. 1983. Rev. ed. Tokyo: Yoshikawa kôbun-kan, 1992.

—_. 'Iezusukai hikaiin no konguregasan to kaisôka'. Shigaku zasshi 103 (1994): 35-73.

Higashino, Toshio. Nanban'i arumeida. Tokyo: Kashiwa shobô, 1993.

Hakuda, Ajirô. Nippon sonraku no minzokuteki kôzô. Tokyo: Kôbun-dô, 1982.

Kishino, Hisashi. Zabieru to Nippon. Tokyo: Yoshikawa Kôbun-kan, 1998.

Kudamatsu, Kazunori. Kirishitan denraichi no jinja to shinkô. Ômura, Nagasaki: Tomimatsu jinja saikô yonhyakunen jigyô iinkai, 2002.

Matsuda, Kiichi. Nippo koshôshi. Shinwa bunko 6. Tokyo: Kyôbun-kan, 1963.

- Nanban shiryô no hakken: Yomigaeru Nobunaga jidai. Chûkô shinsho 51. Tokyo: Chuôkôron-sha, 1964.

—. Nichiô kôshôshi bunken mokuroku. Tokyo: Keibun-dô \& Issei-dô, 1965.

—. Taikô to gaikô. Tokyo: Tôgen-sha, 1966.

—. Nanban junrei. Tokyo: Asahi shinbun-sha, 1967.

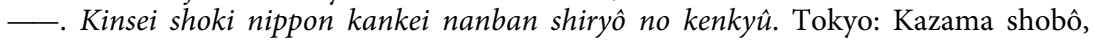
1967.

—. Keichô shisetsu: Nipponjin hatsu no taiheiyô ôdan. Tokyo: Shin jinbutsu ôraisha, 1969.

—. Hideyoshi no nanban gaikô: San Felipegô jiken. Tokyo: Shin jinbutsu ôrai-sha, 1972.

- Kirishitan kenkyû. Vol. II: Ronbakuhen. Tokyo: Kazama shobô, 1975.

- 'Kaidai' [Introduction]. Vol. I of Furoisu Nipponshi. By Kiichi Matsuda \& Momota Kawasaki. 1977.

—. Shitan tenshô ken'ô shisetsu. Tokyo: Kôdan-sha, 1977.

- Ômura Sumitada-den. 1955. 3rd ed. Tokyo: Kyôbun-kan, 1978. [Biography of Ômura Sumitomo]

—. 'Nazo wo himeta bunsho'. Frois no Nippon oboegaki. By Kiichi Matsuda \& Engelbert Jorißen. 1983

Matsuda, Kiichi et al., eds. \& trans. Nippon kankei Iezusukai genbunsho. Kyoto: Dôhôsha, 1987.

Containing photographs of the original text, the printed text and the Japanese translation.

Murai, Sanae. Bakuhansei seiritsu to kirishitan kinsei. Tokyo: Bunken shuppan, 1987.

- Kirishitan kinsei to minshû no shûkyô. Tokyo: Yamakawa shuppan-sha, 2002.

Murakami, Naojirô, trans. Ikoku nisshishô. Tokyo: Sanshû-sha, 1911.

—. Yaso-kai nenpô. Nagasaki sôsho 2. Nagasaki: Nagasaki shiyakusho, 1926.

—, trans. Yasokai Nippon tsûshin: Keikihen. 2 vols. Ed. Watanabe Yosuke. Tokyo: Sunnan-sha, 1927-28. 
__ trans. Ikoku ôfuku shokanshû. Tokyo: Sunnan-sha, 1929.

[reprinted by Yûshô-dô, Tokyo, in 1966]

_ , trans. Ikoku nikkishô. Enlarged ed. of Ikoku nisshishô. Compiled with Ikoku offuku shokan-shû. Tokyo: Sunnan-sha, 1929.

_

[re-edited by Takeo Yanagiya in 1968-69]

—-, trans. Deshima rankan nisshi. 3 vols. Tokyo: Bunmei kyôkai, 1938-39.

—_, trans. Yaso-kai no Nippon nenpô. 2 vols. Tokyo: Takubun-dô, 1943-44.

[re-edited by Takeo Yanagiya in 1969]

- trans. Nagasaki Oranda shôkan no nikki. 3 vols. Tokyo: Iwanami shoten, 1956-58.

Okada, Akio. Nanban shûzokukô. Tokyo: Tajin shokan, 1942.

- Okada Akio chosakushû. Ed. Kodama Kôta et al. 6 vols. Tokyo: Shibun-kaku, 1983-84.

Okamoto, Yoshitomo. Jûroku seiki Nichi-Ô kôtsûshi no kenkŷ̂. Tokyo: Kôbunsô, 1936.

—, ed. Gyoson-ki. Tokyo: Tôyô-dô, 1946.

Pastells, Pablo, SJ. Jûroku jûshichi seiki Nippon Supein kôshôshi. Trans. Matsuda Kiichi. Tokyo: Taishûkan shoten, 1994.

Shimizu, Hirokazu. Kirishitan Kinseishi. Tokyo: Kyoiku-sha, 1981.

- Shokuô seiken to Kirishitan. Tokyo: Iwata shoten, 2001.

Takahashi, Hirofumi. Iezusukai-no sekai senryaku. Tokyo: Kôdansha, 2006.

Takase, Kôichirô. Kirishitan jidai no kenkyû. Tokyo: Iwanami shoten, 1977.

Takeuchi, Toshimi. 'Shakai seikatsu'. Nippon minzoku shiryô jiten. Tokyo: Daiichi hôki, 1969.

Uyttenbroeck, Thomas. Jûroku naishi jûshichi seiki no Nippon ni okeru Furanshisukokaishitachi. Trans. Ishii Kengo, Tokyo: Chûô shuppansha, 1980.

Yamaguchi, Yaichirô. Shûraku no kôsei to kinô. Tokyo: Hakubun-sha, 1976. 
Takao Abé - 978-90-04-20965-7 Downloaded from Brill.comఠ4/26/2023 02:17:13PM via free access 
APPENDICES 
Takao Abé - 978-90-04-20965-7 Downloaded from Brill.comఠ4/26/2023 02:17:13PM via free access 


\section{APPENDIX ONE \\ SELECT BIBLIOGRAPHY OF THE MISSIONARY CORRESPONDENCE RELATED TO JAPAN}

[Sources: Johannes Laures, Kirishitan Bunko (Tokyo: Sophia University, 1957), 167-283; and RLG’s Eureka ${ }^{\circledR}$, www.eureka.rlg.ac.uk]

\section{French Publications}

Recueil des plus fraisches lettres des Indies orientales, ...envoiées l'an 1568. 69. \&70.... Paris, 1571.

Nouveaux advis de l'amplification du christianisme ès pays du Iappon, envoyés...par le père François Cabral....Paris, 1579.

Lettres du Iappon, de l'an M.D.LXXIX.... Coppie d'une lettre du père Louys Froes, escrite aux pères \& frères de la Compagnie de Iésus du 6. juing. 1577. Paris, 1580.

Nouveaux advis de l'estat du christianisme ès pays et royaulmes des Indes orientales \& Iappan....Paris, 1582.

Lettres nouvelles du Iappon. Touchant l'advancement de la chrestienté en ces pays la, de l'an 1579 jusques à l'an 1581. Paris, 1584.

Choses diverses des ambassadeurs de trois roys de Iapon, que n'agueires venuz à Romme, rendirent obéissance au nom de leurs maisteres \& seigneurs, à Gregoire XIII. souverain pasteur de l'église....Louan: De l'imprimerie de Iehan Maes, à la Croix verde, 1585 .

Lettre du Iappon de l'an M.D.LXXXII. envoyée...par le P. Gaspar Caelio [Coelio].... Paris, 1586.

Le discovers de la Venue des princes iapponois en Europe, tiré d'un advis venu de Rome.... Traduict nouvellement d'Italian en François. Par Jacques Gaulthier. Paris, 1586.

Annales indiques, contenantes la vraye narration et advis de ce qu'est advenu \& succédé en Iapon, \& aultres lieux voisins des Indes, envoyez par les pères de la Société de Iésus au R. P. Claude Aquaviva Général de la dicté Compagnie en l'an 1588. Anvers, 1590.

Sommaire des lettres du Iappon, et de la Chine de l'an M.D.LXXXIX, \& M.D.XC... Dovay, 1592.

Lettres du Iapon et de la Chine, des années 1589. \& 1590. et certains advis du Peru, des années 1588. \& 1589.... Lyon, 1593.

Relation envoyée par Don Francisque Tello...touchant le martire de six religieux espagnols....Paris, 1599.

Relations des Pères Loys Froes, et Nicolas Pimenta...concernant l'accroissement de la foy chrestienne au Iappon...ès années 1596 \& 1599.... Lyon, 1602.

Nouveaux advis du Royaume de la Chine, du Iappon et de l'Estat du Roy de Mogor... tirez de plusieurs lettres.... Paris, 1604.

Lettre annuelle du Iapon envoyée au [sic, par] P. Pasius Provincial au T. R. P. Claude Aquaviva, Général de la Compagnie de Iésus. Paris: Claude Chappelet, 1605.

Lettre annuelle du Iapon de l'an mil six et trois, escrite par le P. Gabriel de Matos.... Dovay, 1606.

Histoire véritable de la glorieuse mort, que six nobles chrestiens, Iaponois, ont constamment enduré (sic) pour la foy de lésus Christ, envoyée par Monsieur Louys Cerquera (sic)... avec une autre semblable du P. François Passio.... Paris, 1607. 
Lettres annales du Iapon des années 1603. 1604. 1605. \& 1606., envoyées par le R. P. François Pasio, vice-provincial de ces quartier là, au R. P. Claude Aquaviva. Lyon: P. Rigaud, 1609.

João Rodrigues Girão. Lettres annales des royaume du Iapon, et de la Chine, des années 1606. \& 1607., escrites par les Iean Rodriguez, \& Matthieu Ricci, de la Compagnie de Iésus, au R. P. Claude Aquaviva leur général. Paris: Claude Chappelet, 1611.

La glorieuse mort de neuf chrestiens iaponois martyrizez pour la foy catholique aux royaume de Fingo, Sassuma, et Firando envoyée du Iapon l'an 1609. et 1610. au mois de mars par le R. P. Provincial de la Société de Iésus au R. P. Claude Aquaviva. Dovay: P. Auroy, 1612.

Récit de l'entrée solennelle et remarquable, faicte à Rome, à Philippe François Faxicura, et au R. P. Louys Sotelo... ambassadeurs pour Idate Masamune, Roy de Voxu au Japon....Paris, 1616. [a Franciscan report]

Conversion du Roy Ydada Maçamune, et de l'édict qu'il a fait publier...commandant à tous ses vassaux de recevoir la foy chrestienne; et de l'Ambassade que pour c'est effect il a envoyé vers nostre S. Père le pape et le Roy d'Espagne.... Tolose [Toulouse], 1618.

Histoire de l'estat de la chrestienté au Iapon, et du glorieux martyre de plusieurs chrestiens, en la grande persécution de l'an 1612. 1613. et 1614.... Dovay, 1618.

Luis Piñeyro. La nouvelle histoire du Iapon: divisée en cinq livres, ou il est taicté amplement de l'estat de sa chrestienté, du progrès de la foy catholique, des grandes persécutions qui y sont arrivée aux chrestiens, \& des divers martyres qu'un grand nombre, tant religieux que séculiers ont souffert soubs l'empire de Cobusama, jusques à l'année mil six cent quinze. Paris: Iean Foüet, 1618. [Also published under the same and similar two titles by Adrian Taupinart, 1618]

Nicolas Trigau(l)t. Lettre du R. P. Nicolas Trigaut de la Compagnie de Iésus de l'heureux succez de sa navigation aux Indes \& de l'estat de la chrestienté tant en la Chine qu'au Iapon. Lille: De l'Imprimerie de Pierre de Rache, 1620.

Relation de ce qui s'est passé depuis quelques années, jusques à l'an 1644 au Japon, à la Cochinchine, au Malabar... divisée en deux parties.... Première Partie. Relation de la province du Japon. Escrite en Portugais par le Père François Cardim.... Paris, 1646

La vie de Saint François Xavier de la Compagnie de Jésus....Paris, 1682.

\section{Italian Publications}

Avisi particolari delle Indie di Portugallo riceuuti in questi doi anni del 1551. \& 1552.... Roma, 1552.

Nvovi avisi delle Indie di Portugallo riceuuti questo anno del 1553. doue si tratta della cõuersione di molte persone principali, \& tra li altri d'un re signore de 11000. Isole, con vna discrittione delli costumi dei Giaponesi nostri antipodi \& come loro riceuono la nostra Santa Fede. Roma: Valerio Dorcio \& Luigi fratelli. (without date, 1555).

Avisi particolari delle Indie di Portugallo. Nouamente hauuti questo anno del 1555. da li padri della Compagnia di Iesu.... Romae, 1556.

Avisi particolari del avmento che iddio da alla sua chiesa catholica nell'Indie, et specialmente nelli regni di Giappon,... receuuti... questo anno del 1558. Roma, 1558.

Nvovi avisi dell'Indie di Partogallo, riceuuti dalli reuerendi padri della Compagnia di Giesu, tradotti della lingua Spagnuo la nell'Italiana. M.D.L.IX. Venetia: Michele Tramezzino, 1559.

Lettere del Giappone... dell'anno MDLXXVII.... Brescia, 1580.

Lettere dell'India orientale, scritte da'reuerendi padri della Compagnia di Giesù.... Vinegia, 1580.

Alcvne lettere delle cose del Giappone... dell'anno 1579. insino al 1581. Milano, 1584. Alcvne lettere delle cose del Giappone... dell'anno 1579. insino al 1581. Napoli, 1584. 
Relatione de gli honori et accoglienze fatte dall'illustrissima, \& serenissima signoria di Venetia alli signori ambasciatori Giapponesi. Con la copia d'vna scrittura data da detti Giapponesi à sua serenità, scritta in lor lingua sopra vn foglio di scorzo d'albero, tradotta in nostra lingua. Con li doni fatti dall'illustriss. Senato a'detti sig.Giapponesi, \& dalli detti all'illustris. Signoria. Cremona: Appresso Christoforo Draconi, 1585.

Relatione del viaggio, et arrivo in Europa, et Roma, de'prencipi Giapponesi venuti à dare obedienza à sua santità l'anno M.D.LXXXV. All'eccellentiss Sig. Girolamo Mercuriale. Reggio, 1585.

Le istorie delle Indie orientali del Rev. P. Giovan Pietro Maffei.... Fiorenza, 1589.

Lettere del Giappone et della China de gl'anni M.D.LXXXIX. \& M.D.XC. scritte al R. P. Generale della Compagnia di Giesu. Brescia: Appresso Vincenzo Sabbio, 1592.

\section{Latin Publications}

Rerum a Societate Iesu in oriente gestarum ad annum usque... M.D.LXVIII. commentarius Emanuelis Acostae Lusitani, recognitus, \& latinitate donatus. Accessere de Iaponicis revus epistolarum libri IIII.... Dilingae, 1571.

Emauelis Acostae Lusitani historia rerum a Societate Iesu in oriête gestarum, ad annum... MDLXVIII, recognita \& latinitate donota. Accessere de Iaponicis revus epistolarum libri IIII....Et recentium de rebus indicis epistolarum liber usque ad annum 1570. Parisiis, 1572.

Rerum a Societate Iesu in oriente gestarum volvmen.... Neapoli, 1573.

Brevis Iapaniae insulae descriptio... item, insigne quoddam martyrium.... Coloniae Agrippinae, 1582.

Annuae litterae Societatis Iesu anni M.D.LXXXIII ad patres, et fratres eiusdem Societatis. Romae: Collegio eiusdem Societatis, 1585.

Ioannis Petri Maffeii... historiarum Indicarum libri XVI. Selectarum item ex india epistolarum eodem interprete libri IV. Accessit Ignatii Loiolae vita postremo recognita.... Florentiae, 1588.

Nova relatio historica de statu rei christianae in Japonia...A. R. P. Aloysio Frois.... Moguntiae, 1598.

Iapponiensis imperii admirabilis commutatio exposita litteris...quas ex Italis latinas fecit Io. Hayus.... Antverpiae, 1604. 


\section{APPENDIX TWO \\ LIST OF PUBLICATIONS BY SCHILLING, SCHURHAMMER AND SCHÜTTE}

\section{Dorotheus Schilling, OFM}

\section{A. Publications of Manuscripts}

[Luis Frois]

Dorotheus Schilling. 'Neue Funde zur História de Japão von Luis Frois S. J.' Zeitschrift für Missionswissenschaft 23 (1933).

[Bernardino de Avila-Girón's Second Editon]

Doroteo Schilling \& Fidel de Lejarza, eds. 'Relación del Reino de Nippon'. Archivo Ibero-Americano 36 (1933): 481-531; 37 (1934): 5-48, 259-75, 392-434, 493-554; 38 (1935): 103-30, 216-39, 384-417.

\section{B. Other Topics}

Dorotheus Schilling. Das Schulwesen der Jesuiten in Japan (1551-1614). Münster, Westfallen: Regensbergschen Buchdruckerei, 1931

- 'Attivià Scolastica dei Gesuiti nel Giappone durante i secoli XVI ${ }^{\mathrm{e}}$ XVII'. Pensier Missionario 9 (1937): 03-29.

- . 'Die Schultätigkeit der Jesuiten in Japan während des 16. und 17. Jahrhunderts'. Die Katholischen Missionen 65 (1937): 211-25, 239-43 \& 294-97.

- Religione e Politica in Giappone. Roma: Pontificium Athenæum Antoianum, 1950.

\section{Georg Schurhammer, SJ}

\section{A. Publications of Manuscripts}

[Luis Frois]

Georg Schurhammer und E. A. Voretzch, trans. 1926. Die Geschichte Japans (15491578). Leipzig: Verlag der Asia Major, 1926.

[Francisco de Xavier]

Georg Schurhammer. Zwei Undruckte Briefs des Hl. Franz Xavier. Vol. II of Archivum Historicum Societatis Iesu. Roma, 1933.

- Ein Neuer Xaveriusbrief. Vol. XVI of Archivum Historicum Societatis Iesu. Roma, 1947.

—. Epistoloe S. Francisci Xavierii aliaque eius scripta. Ed. Georg Schurhammer, SJ, \& J. Wicki, SJ. 2 tomus. Romae: Monumenta Historica Soc. Jesu, 1944-45.

[Fernão Mendez Pinto]

Georg Schurhammer. 'Um documento inédito sobre Fernão Mendez Pinto'. Revista de História 13 (1924): 81-88. 


\section{B. Jesuit Missionaries}

[On Francisco de Xavier]

Georg Schurhammer. 'Die asiatische Missionslage zur Zeit des hl. Franz Xavier und der heutige Stand der Glaubensverbreitung in Wirkungsfeld dieses Apostels'. Priester und Mission 1 (1918): 45-59.

—. 'Der hl. Franz Xavier in Miyako'. Stimmen der Zeit 100 (1921): 440-55.

—. 'Xaveriusforschung in 16. Jahrhundert'. Zeitschrift für Missionswissenschaft 12 (1922): 129-65.

-. Der Heilige Franz Xavier: Der Apostel von Indien und Japan. Freiburg im Breisgau: Herder, 1925.

—. 'Franz Xavier'. Lexikon für Theologie und Kirche IV. 1932.

. 'Zur Kritik der Missionserfolge des hl. Franz Xavier'. Stimmen der Zeit 125 (1933): 324-32.

- 'Der Hl. Franz Xavier in Japan, 1549-1551'. Neue Zeitschrift für Missionswissenschaft/Neuvelle Revue de science missionaire 2 (1946): 165-86 \& 255-73.

-. Franz Xavier: Sein Leben und seine Zeit. 2 Bde. Freiburg: Herder, 1955-1963.

Schurhammer, Georg \& R. E. Kepler. Franziskus Xaverius: Ein Leben in Bildern. Aachen: Xaverius-Verlag, 1922.

[On Luis Frois]

Georg Schurhammer. 'P. Luis Frois, S. J.: Ein Missionshistoriker des 16. Jahrhunderts in Indien und Japan'. Stimmen der Zeit 109 (1925): 453-69.

—. 'Luis Frois'. Lexikon für Theologie und Kirche IV. 1932.

[On Other Jesuits]

Georg Schurhammer. Fernão Mendez Pinto und seine Peregrinçam. Sonderdruck aus Asia Minor, vol. III. Leipzig: Verlag der Asia Minor, 1927.

—. Die Disputation des P. Cosme de Torres, S. J., mit den Buddhisten in Yamaguchi im Jahre 1551. 'Mitteilungen' der Deutsche Gesellschaft für Natür- und Völkerkunde Ostasiens. Band XXIV. Teil A. Tokyo, 1929.

—. 'João Rodriguez S. J.' Lexikon für Theologie und Kirche VIII. 1936.

'Alessandro Valignani S. J.' Lexikon für Theologie und Kirche X. 1939.

\section{Jesuit Missions}

Georg Schuhammer. 'Die Erste Japanische Gesandschaftsreise nach Europa (15821590)'. Die Katholischen Missionen 49 (1921): 217-224.

_- Das kirchliche Sprachproblem in der Japanischen Jesuitenmissionen des 16. 17. Jahrhunderts: Ein Stück Ritenfrage in Japan. 'Mitteilungen' der Deutsche Gesellschaft für Natür- und Völkerkunde Ostasiens. Band XXIII. Tokyo, 1928.

\section{Portuguese Colonies}

Georg Schurhammer. 'Die Schätze der Jesuitenarchive in Macao und Peking'. Die Katholischen Missionen 57 (1929): 224-29.

_- Die zeitgenössichen Quellen zur Geschichte Portugiesisch-Asiens und seiner Nachbarländer (Ostafrika, Abessinien, Arabien, Persien, Vorder- und Hinterindien, Malaiischer Archipel, Philippinen, China und Japan) zur Zeit des Hl. Franz Xavier (1538-1552). Leipzig: Verlag der Asia Minor, 1932.

- The Malabar Church and Rome during the Early Portuguese Period and Before.

Trichinopoly: St. Jeseph's Industrial School Press, 1934.

—. 'Uma Relação Inédita do Pe. Manuel Barradas S. J. São Francisco Xavier'. STVDIA

2: 43-90. Lisboa: Centro de Etudos Históricos Ultramarinos, 1958. 
Georg Schurhammer \& E. A. Voretzsch. Ceylon zur Zeit des Königs Bhuvaneka und Franz Xaviers, 1539-1552: Quellen zur geschichte der Portugiesen, sowie der Franziskaner- und Jesuitenmission auf Ceylon im Urtext herausgegeben und erklärt von G. Schurhammer und E. A. Voretzsch. 2 vols. Leipzig: Verlag der Asia Minor, 1928.

\section{E. Shintoism}

Georg Schurhammer. Shin-To, der Weg der Götter in Japan: Der Shintoismus nach den gedrucken und ungedrucken Berichten der Japanischen Jesuitenmissionare des 16. und 17. Jahrhunderts. Bonn und Leipzig: K. Schröder, 1923.

- 'Der Shintoismus und die neueste Forschung'. Die Katholischen Missionen 54 (1926): 178-9.

\section{Josef Franz Schütte, SJ}

\section{A. Publications of Manuscripts}

Josef Franz Schütte. Christliche Japanische Literatur, Bilder und Druckblätter in einem unbekannten vatikanische Codex aus dem Jahre 1591. Vol. IX-2 of Archivum Historicum Societatis Iesu. Roma, 1940.

—. Unbeachte und unbekannte Päpistliche Japanschreiben. Vol. XVII of Archivum Historicum Societatis Jesu. Roma, 1948.

- - trans. Kulturgegensätze Europa-Japan, 1585: Tratado em que se contem muito susinta e abreviadamente algumas contradições e diferenças de custumes antre a gente de Europa e esta provincia de Japão. By Luis Frois. Tokyo, 1955.

- Documentos sobre el Japón conservados en la Colección 'Cortés' de la Real Academia de la Historia. 1960. Madrid: Mæstre, 1961. [Formerly published as Bolétin de la Real Academia de la Historia. Tomo CXLVII. Cuaderno I \& Cuaderno II. 1960]

- Wiederentdeckung des Fernost-Archivs der Jesuiten, Heute in Madrid. Archivum Historicum Societatis Iesu. Anno 30. Facs. 59. Roma, 1961.

- 'História inédita dos Bispos da Igreja do Japão' do Pe. João Rodriguez Tçuzu, S. J.' Actas 5: 297-327. Lisboa: Congresso International de Historia dos descobrimentos, 1961.

— - 'P. Joseph Montanha's ,Apparatos' und die Abschrift des Fernost-Archivs S. J. im Rahmen der Initiative der Academia Real da História Portuguesa'. Vol. XXXI of Archivum Historicum Societatis Iesu. Roma, 1962. pp. 225-263.

- El «Archivo del Japón»: Vicitudes del Archivo Jesuítico del extremo oriente y descriptión del fondo existnte en la Real Academia de la Historia de Madrid. Tomo XX de Archivo documental español. Madrid: la Real Academia de la Historia, 1964.

-. Introductio ad Historiam Societatis Jesu in Japonia, 1549-1650, ac Promium ad Catalogos Japonice Edendos ad Edenda Societatis Jesu Monumenta Historica Japonice Proyloum. Romæ: Institutum Historicum Soc. Jesu, 1968.

\section{B. On Alessandro Valignano}

Joef Franz Schütte. Alexandro Valignanos Ringen um die Missionsmethode in Japan, Juli-Dezember 1579. Romae: Typis Pontificiae Yniversitatis Gregorianae, 1944.

- Valignanos Missionsgrundsätze für Japan. 2 vols. Roma: Edizioni di Storia e Letteratura, 1951-58.

—_. 'Missionsgrundsätze des Alexandro Valignano S[.] J. für Japan'. Die Katholischen Missionen 72: 74-75, 1953. 


\section{INDEX}

Aataentsic, 10, 41, 42, 69, 76

Abenaki, 187, 191, 195

Acadia, 63, 64, 66, 68, 70, 101, 104, 105, 108n, 109n, 118

Aenons, 77

Africans, 51

Agnus Dei, 169

Agreskoui, 188

Albuquerque, J. de, 85

Alcáçova, P. de, 92n, 172, 173, 176

Algonquian, 37, 38, 40, 64, 69, 72, $105-107,109,110,129,154$

Algonquin, 64n, 70, 77, 109, 110, 112, $114,118,120,147,149-151,153 n$, $154,155,158,162,181-184,186$, 190-198, 206

Allumette Island, 150, 155

Almeida, L. de, 93-95, 171, 175, 176

Amida, 52, 53, 56

Anderson, K., 11n, 43, 180

Anenkhiondic, 77

Anesaki, M., 26, 27

Apostle Thomas, 53, 68

Aquaviva, C., 59

Argentina, 130

Arima, 58, 85, 94, 95, 135, 139, 140n

Arima, Harunobu, 135, 170, 176

Ashikaga, Yoshiaki, 85

Ashikaga, Yoshiteru, 85

Asunción, 133n, 136, 148

Atahocan/Atachocam, 69

Ataronchronon, 123

Atiwandaronk, 75, 196

Attignawantan, 123

Attikamègue, 147, 183, 190, 191, 197

arendiowane/arendiwane, 185, 188, 195, $196 n$

Auger, É., 4

Avila-Girón, 21

Axtell, J., 76, 77n, 102-104, 116, 117, $180,189 n, 190 \mathrm{n}$

Azuchi, 95

Bailey, A. G., 38-40, 67n, 181n

bandeirantes, 144

baptism, 63, 82-84, 91, 96, 97, 99, $107-111,118,135,158,160,174,175$, 181-184, 190-193, 196-198 bark wigwams, 154

Bartoli, D., 18

Bautista, João/Juan, 172, 174

Bautista, P., 98, 99

Biard, P., 63, 64, 68, 69n, 70, 73n, 77, 108 n, 109n, 117, 118n, 152n, 159, 160

Binet, É., 156n, 157, 158n

Blackburn, C., 11n, 43, 62, 101, 102n, $111 \mathrm{n}, 113 \mathrm{n}, 131,132 \mathrm{n}, 180,200$

Blanchard, D., 165, 166, 167, 212

Bolivia, 130, 132

bonzes, 59, 73, 74, 143

Borgia, F., 4n, 5

Boxer, C. R., 22-24

Brazil, 97n, 130, 132, 144n, 148

Brébeuf, J. de, 4, 66, 69-78, 105-109, $110 \mathrm{n}, 120,160 \mathrm{n}, 180 \mathrm{n}, 181 \mathrm{n}, 184 \mathrm{n}$, $185,188,189,191,192 \mathrm{n}, 196,198$, $199 \mathrm{n}$

Bressani, F. J., 122n, 186, 188, 193, 194n, $202 \mathrm{n}$

Buddha, 19n, 20n, 53, 54, 56n, 74

Buddhism, 19n, 51-54, 56, 60, 80, 167, $170,181,200$

Buddhists, 3n, 29, 51-59, 70, 73, 74, 85, $94,95,97,116,140,142,143,156$, 157, 169-173, 175, 176, 178, 196

Bungo, 25n, 52n, 55, 58, 85, 91, 92n, 93n, 94, 95n, 137n, 170, 171n, 173, 174

Buteux, J., 109, 118, 121, 189, 190

Cabral, F., 50, 57, 140n, 173n

caciques, 136, 139, 155

Campbell, T. J., 2n, 34-36

Campeau, L., 38, 41, 42, 70

Caribbean, 132

Carlos V, 49

cartas anuas, 141, 145

Cary, O., 18-21

catechisms, 29, 106, 113, 121, 184

catequistas, 141, 156, 158

Caughnawaga, 165, 167

Central Mexico, 132

Charlevoix, P. F. X. de, 2, 7, 18-21, 31-33

Chastellain, P., 109

Chile, 130, 134n 
China, 4, 49, 92

Chiwatenhwa, 110n, 118

Cochin, 3n, 52n, 58n, 83, 84n, 85n, 96n, $107 \mathrm{n}, 169 \mathrm{n}$

Coelho, G., 97n, 140, 169, 174n

coffins, 177

Company of One Hundred Associates, $106,121,122$. See also Company of New France

Company of New France, 149. See also Company of One Hundred Associates

Confucianism, 29

Constitutions of the Society of Jesus, 91n, 93n

councils, 23n, 77, 78, 139, 184, 191197

Creation, 54, 69, 70, 80, 138, 163, 202, 206

crucifixes, $89,170,174-178,185,187$, 197-199

daimyô, 30, 56n, 59, 84, 85, 91, 98, 135, $136,140,179$

Daniel, A., 107

Delplace, L., 18, 19

demons/demonism, 52, 55-57, 60, 62, $69,72-77,79,80$. See also devils and diabolism

Deslandres, D., 43

devils, 55, 56, 57, 72-77, 80, 188, 189, 199. See also demons/demonism

diabolism, 57, 203. See also demons/ demonism

Dickason, O. P., 38, 40, 41n

dóbuqu/dôbuku, 51

dogicos, 142, 156n, 157

dojiques, 142, 156, 157

dôjuku, 141n, 142, 143, 146, 156-158, 163,206

donnés, 142, 156, 158n

Druillèttes, G. 187, 191

Dutch, 2, 6, 19, 25

Eastern Woodlands, 110, 148

Ebisawa, A., 26, 28, 29

Elison, G., 22-24

Emerson, J. N., 36, 37n

encomiendas, 133, 136n, 144

England, 34, 106

ethnocentrism, 39

Etinechkawat, 155

Evora, 26, 142n

Faillon, É. M., 32, 33

feasts, $73,75,76,78,110 \mathrm{n}, 170,171$, $180,185,190$
Felipe, the king of Castile, 49

Ferland, J. B. A., 32, 33, 35, 39

Fernández, J., 56, 92n, 94, 171n

feudalism, 57

Figuereido, Melchior/Belchior de, 59n, $85,91 \mathrm{n}$

Fléché, J., 63

Formulae of the Institute of the Society of Jesus, 91, 112

Fort Richelieu, 151, 152

Fort Saint-Louis, 121

France, 3, 4, 6, 17, 21, 31-33, 35, 44, 45, $61 \mathrm{n}, 69,103-108,111,112,121,123$, $157,159,166,198$

Franciscans, 10, 20, 64, 66, 81, 98-109, 111-113, 127, 131, 132, 201, 204

Frois, L., 21, 22, 25n, 26, 50-59, 85, 91n, 92, 93n, 94, 95n, 97n, 98n, 99, 135, $140,142 \mathrm{n}, 143 \mathrm{n}, 170,171 \mathrm{n}, 172 \mathrm{n}$, $173 n, 174-176$

Fujita, N. S., 24, 26, 29, 30, 100n, 169, 170

Fukuoka, 176, 177

Funai, 91-93, 170, 172n, 174, 176, 177

Garneau, F. X., 32, 33, 39

general superior, see superior general

Georgian Bay, 65, 107

Gion, 170

Goa, 5, 49

Goddard, P., 76, 77n

Gómez, P., 99

Gonoi, T., 29, 143n

Gotô, 167, 172n

Gotô, J., 134

Grant, J. W., 38, 41, 42, 101, 113n

Gravier, G., 130

Great Lakes, 37, 40, 67n, 204

Guaraní, 137, 139, 144n, 151

Guazú, S. I., 136, 148

Guzmàn, L. de, 18

Haas, H., 18-21

Heidenreich, C. E., 37

Hell, 73, 76, 108

Henriques, H., 83

Hindu, 83

Hirado, 52n, 92, 94, 96, 98, 175

Historia de Iapam, 25n, 85n,135n, 172n, 175

Hizen, 85, 135-140, 146n, 147, 148, 151, $154,156,162,178,205,206$

Hokkaido, 2

Hospital nuns, 122, 122, 152, 154, 158, 160,184 
Hôtel-Dieu de Québec, 122, 123

hotoke, 53

Hudson Bay, 4

Huron, 31-33, 35-37, 40-43, 65-67, 69-75, 77, 80, 104, 106-115, 117-120, $122,124,126,127,147,149,151$, 157-159, 162, 181-196, 198, 199

Huron country [or the country of the Hurons], 4, 36, 37, 71, 72, 74, 106-110, 115, 119, 123, 187, 194. See also Huronia

Huronia, 36, 104, 110, 115, 120, 157, $160,182,192,196-198$. See also Huron country

Ichiku, 175

icons, (Christian) 51, 97, 165, 169, 174; (other) 51, 53, 56, 165, 178

Ihonatiria, 149, 159, 184, 185, 197

Ikitsuki Island, 94, 175

Île d'Orléans, 147, 151, 184

India, 10, 30, 49, 82-84, 95, 117

indulgence, 175

Innu, 3, 64-66, 72-74, 77, 107, 109, 111-114, 118, 122, 130, 147, 150, 151, 154-156, 158, 160, 162, 181-183, 186-196, 198, 199, 206

Iouskeha/Jouskeha, 69

Iroquoian, 37, 65, 72, 105-107, 129, 154, $165,167,181 \mathrm{n}$

Iroquois, 32, 33n, 37, 38n, 40, 42, 65n, $112,120,122,148,151,158,167,188$

irmãos da misericordia, 92

Isabella, the queen of Castile, 49

Island of Miskou, 192

Italy, 1, 5

Izanagi, 54

Izanami, 54

Jaenen, C. J., 38-41, 102, 131, 132n

Jenness, D., 37

Jetten, M., 3n, 131

Jouvency, J., 68

Jury, E. M., 36

Jury, W., 36

Kagoshima, 1, 48, 96, 175

kami, 53, 54, 56

kanbô, 142, 143

kannon, 52, 53, 56

kappa, 173

Kawasaki, M., 21n, 26n, 85n, 93n, 95n, $135 \mathrm{n}$

Kennedy, J. H., 38, 39
Khichikouai, 69

Kichesipiirini, 150, 155, 156n

kimono, 51

Kinietz, W. V., 37, 67n, 70, 74n

Kirke brothers, 106

Kisai, D., 134

kô, 171

Kôbôdaishi, 56

Kôbôsama, 58

Kuchinotsu, 94, 136, 170

Kumamoto, 176

Kutami, 55

Kyoto, 54, 57, 58, 85, 99, 169, 173, 175

Kyushu, 5, 14, 55, 58, 135, 138, 176

La Conception, 147

La Roche d'Aillon, Joseph de, 106

Lafitau, J. F., 2, 3n

Lafléche, G., 44

Lainez, D., 5

Lake Ontario, 148

Lake Simcoe, 65, 182, 191

Lalemant, C., 65, 67-71, 105

Lalemant, J., 4, 44, 45, 72, 73, 75, 76, 78, $110,114,115,117,119,120,123,147$, $148,150,157,159,183,188,189,192$, 193, 196,197, 198

Latta, M. A., 36, 37n

Laures, J., 5, 6, 22, 23, 26

Le Caron, J., 104

Le Jeune, P., 3, 4, 65-67, 69-74, 77, 106, $107,109-115,117-123,129,130,150$, 155, 157, 159-161, 186-188, 190, 191, 193, 194, 196-198

Le Mercier, F. J., 44, 45, 72, 78, 109, 118, 147, 186, 196

Lejarza, F. de, 21

leprosaria, 92

Les Relations des Jésuites, 3

Lévis, H. de, Duc de Vendatour, 105, 106n

liquor, 147, 149, 160

Lisbon, 21

longhouses, 105

Lorenzana, M. de, 136

Loreto, 144

Los Santos Mártires de Japón, 134

Loyola, I. de, 5, 55, 56, 83

Lucifer, 55

ma, 55

Macao, 5, 21, 136, 142n

magistrats, 155

Magnuson, R., 101, 103n, 111n, 113n, 115,116 n 
Makheabichtichiou, 77, 118

Malacca, 5

Mali, A., 101, 113n

Maliseet, 63, 64n

Manila, 5, 98

manitou, 72-74, 80, 187-189, 191, 194-196, 198

Manitouchatche, 191

Manitousisiouekhi, 196

martyrs/martyrdom, 23, 44, 45, 99n, $134,174,176$

Mass, 3, 91, 113, 141, 147, 151, 169, 179, 185

Massé, Énemond/Ennemond, 63, 64, 105

Matsuda, K., 25, 26

Matsuura, Shigenobu, 98.

Matuura, 92

McIlwraith, T. F., 36

McMullen, J. M., 34

medals, 177, 178, 197

medicine men, 73

Meiji, 24, 171

Membertou, 77

Messsou, 69

Mexico, 131, 132, 133n

Mi'kmaq, 63, 64n, 77, 118

Miki, P., 134

miko, 172

miyaza, 171

Mohawk, 35n, 151, 167

Moluccas, $4 \mathrm{n}$

Montagnais, 3, 64, 65n, 106n. See also Innu

Montmagny, C. H. de, 118, 155

Montoya, A. R. de, 133, 134, 138, 139, 144

Montreal, 3, 147, 165, 167

Moran, J. F., 24

Morgan, H., 37

Mount Atago, 57

Murai, S., 29

Murakami, N., 25

Murdoch, J., 18, 20

Nagasaki, 85, 87, 90, 92, 99, 134-137, $148,149,163,169,174,176$

Nara, 57

Neutral, 75

New England, 106

Niirô Iseno Kami Yasuhisa, 175

Nipinouskhé, 69

Niscaminou, 68
Normans, 63

Notre-Dame-des-Anges, 103, 112-114

Nouë, A. de, 66, 105, 106, 109

Noyrot, P., 105

Nuestra Señora de los Reyes de Yapeyú, 148

Nueva España [or New Spain], 4, 5, 49, 131

Oda, Nobunaga, 58, 85

ohyakudo mairi, 172

Ôita, 176

Okada, A., 26-28

Okamoto, Y., 25-27

okata/saokata, 195

oki, 72, 73, 80,188, 189, 195, 196

oki ontatechiata, 196

Ômura, 58, 85, 135, 139, 140, 142, 167

Ômura, Sumitada, 26n, 92, 135, 137, 140,174

ondaki, 72,89

onniont, 198

Ontario, 34, 37, 41, 148

ontetsans/aretsans, 195

Orr, R. B., 36

Osaka, 85, 99, 176

Ossossané, 111, 118, 149, 185, 186, 196, 197

Ôtomo, 58, 91, 177

Ôtomo, Yoshishige, 93

Ôuchi, Yoshitaka, 85

Pacific Ocean, 4, 29

pagans/paganism, 28, 48, 51, 52, 56, 59, $67,68,110$

Pagès L., 18, 21

Paraguay, 10, 11, 129-141, 143-150, 152-159, 161-163, 201, 205, 206

Paraná River, 134

Paris, 1, 3, 64, 106, 111, 123

patriarchy, 43

Péron, F. du, 72, 73n, 198

Peru, 132

philanthropy, 27, 91, 92, 117, 119, 122, $123,127,152,153,160-162,166,168$, $169,171,172,185,206$

Philippines, 49, 98, 100, 131, 136

Pijart, C., 121

Pijart, P., 4

Pipounoukhe, 69

Popham, R. E., 36

Port Saint John, 63

Portugal, 1, 22, 26, 49, 83 
prayers, 3, 55, 68, 69, 82, 96, 113, 115 , $121,155,158,172,175,185-187$, 191-193, 196, 207

Principe, C., 101, 113n

proscription [of Christianity], 25, 29, 99, 167

pueblo reales, 132

qimão [or kimono], 51

Quebec, 3, 32, 33, 39, 41, 63, 64, 65, 66, 69, 70, 86, 101, 103, 104, 106-109, 111-113, 116, 117, 120-123, 131, 147-150, 152, 153, 155, 158-160, 182, $184,190,193,194,197$

Quen, J. de, 199

Ragueneau, P., 72, 111, 158, 160, 187, 188, 191, 192, 194, 198

Ratio Studiorum, 114

Récollet Franciscans, 64, 101, 108

reducciónes, 10, 11, 129-139, 144-151, 155-157, 161-163, 201, 205, 206

réductions, $10,11,129-132,135$, 146-151, 153-158, 160-163, 179, 182, 184, 187, 194, 197, 201, 205-207

Richelieu, 106, 123

Rio Grande do Sul, 148

Rochemonteix, C. de, 32, 33, 35

Rodrigues, Simão, 49, 83

Rodrigues, Giram, 142n

Rodriguez-Tçuzu, J., 22, 138n, 139

Rome, 11, 17, 20, 22, 42, 50, 59, 157

rosaries, 169, 172, 174, 177, 197

Ross, A. C., 24

Roy, J. E., 130, 131n

Sá, G. de, 85

Saga, 85, 135

Sagard, G., 133n, 104n, 108, 151n

Saint Joseph, 110, 150

Saint Lawrence, 4, 10, 35, 36, 39, 66, 70, $77,101,103,105,108,109,111,129$, 131, 148, 153, 190, 192, 204

Sainte-Croix, 130

Sainte Marie, 36, 110, 111n, 123, 124, 125,126

Sakai, 53, 173

San Ignacio Mini, 144

San Martín, F. de, 136

San Miguel, 148

Satan, 52, 57, 73

Schilling, D., 20, 21, 226

Schurhammer, G., 20, 21, 22, 226
Schütte, J. F., 22n, 50, 142n, 143n, 157, 228

Scot, D., 157, 158n

Settsu, 92

Shaka, 52-56

shamans/shamanism, 55, 57, 72-75, 118, $172,179,185,188,189-191,194-196$, 200

Shimabara, 176

Shimizu, H., 26, 29

Shintô, 21, 52, 54n, 55, 56, 60, 73, 74, $97,140,167,169-173,175,176,178$, $181,196,200$

Sillery, 110, 120-122, 130, 147-152, 154-156, 160, 161, 179, 181-184, 187, 191-193, 197-199

Silva, D. da, 55, 173n

Simard, J. J., 131

sin, 54, 83, 169, 175

Sioui, G. E., 62, 70n

sky world, 54, 167

Smith, W., 34

soothsayers, 73

Sorbonne, 108

sorcerers, 73,74

soul, 3, 53, 57, 70, 71, 80, 82, 93, 96, 102, 108, 172, 195

South China Sea, 49

Spain, 1, 22, 49, 61n

[The] Spiritual Exercises, 55

Steckley, J., 37

Sulte, B., 32, 33, 39

superior general [or general superior], 5, $50,55,58,193$

Tadoussac, 151, 155, 158, 184, 199

Takahashi, H., 29, 30

Takase, K., 26, 29

Takayama, 85, 92

Takayama Hidanokami, 92

Takushima Island, 94

Tamil, 82, 83

Tawiscaron, 69

Teanaostaiaé, 149, 158

Tebicuary Rivers, 148

Tekakwitha, K., 167

Ten Commandments, 84, 91

theocracy, 58

Thwaites, R. G., 35

Tokugawa, 27, 29, 99n

Tooker, E., 37, 62, 63n, 67n, 70n, 181n, $196 n$

Torres, C. de, 56, 58, 91, 92, 123, 144, 174, 176 
Totiri, É., 158

Toulouse, 21

Toyotomi, Hideyoshi, 58, 98, 99n, 134

Trigger, B. G., 10n, 38, 40-42, 62, 63n, $67,76,77 \mathrm{n}, 101,103,106,108 \mathrm{n}, 111$, $113 \mathrm{n}, 116,117,123,131,184 \mathrm{n}$

Trois-Rivières, 109, 118, 120, 122, 147, $148,150,151,160,182,184,190,191$, 194, 195, 198

Trudel, M., 38, 39

Tsiouendaentaha, 118

Uruguay, 130, 134, 148

Uruguay River, 134, 148

Ursulines, 86, 121, 122, 130, 152, 183

Valence, 4

Valignano, A., 22, 24, 26, 30, 50, 58, 95-97, 99, 138, 140, 142, 169

Vaz, M., 55

Viel, N., 104, 104n

Viela, G., 50, 52-54, 56, 57, 169, 175

Vignerot, M. M. de, Duchesse d'Aiguillon, 123
Vimont, Barthélemy/Barthélemi, 110, $115,117,120,121,152,179,181,184$, 187

Vincent, M. T., 37, 38n

Vitelleschi, Mutius/Mutio, 193

war chiefs, 77,78

water [as in holy/sacred water], 173, 174, 197-199

Whelan, C., 165-167, 178

Wright, J. V., 37

Xavier, F. de, 1, 3, 4n, 7, 9, 12, 21, 23, $48,49,52,56,58,63,66,67,82-85$, $91,96,107,119,123,127,134,138$, 150, 175, 201, 202, 204

yamabushi, 57, 75, 172

Yamagata, I., 20

Yamaguchi, 56, 91, 92, 96

Yavevirí, 144

Yokoseura, 136 


\title{
Studies in the History of Christian Traditions
}

\author{
(formerly Studies in the History of Christian Thought)
}

\author{
Edited by Robert J. Bast
}

1. McNeill, J. J. The Blondelian Synthesis. 1966. Out of print

2. Goertz, H.-J. Innere und äussere Ordnung in der Theologie Thomas Müntzers. 1967

3. Bauman, Cl. Gewaltlosigkeit im Täufertum. 1968

4. Roldanus, J. Le Christ et l'Homme dans la Théologie d'Athanase d'Alexandrie. 2nd ed. 1977

5. Milner, Jr., B. Ch. Calvin's Doctrine of the Church. 1970. Out of print

6. Tierney, B. Origins of Papal Infallibility, 1150-1350. 2nd ed. 1988

7. Oldfield, J. J. Tolerance in the Writings of Félicité Lamennais 1809-1831. 1973

8. Oberman, H. A. (ed.). Luther and the Dawn of the Modern Era. 1974. Out of print

9. Holeczek, H. Humanistische Bibelphilologie bei Erasmus, Thomas More und William Tyndale. 1975

10. Farr, W. John Wyclif as Legal Reformer. 1974

11. Purcell, M. Papal Crusading Policy 1244-1291. 1975

12. Ball, B. W. A Great Expectation. Eschatological Thought in English Protestantism. 1975

13. Stieber, J. W. Pope Eugenius IV, the Council of Basel, and the Empire. 1978. Out of print

14. Partee, Ch. Calvin and Classical Philosophy. 1977

15. Misner, P. Papacy and Development. Newman and the Primacy of the Pope. 1976

16. Tavard, G. H. The Seventeenth-Century Tradition. A Study in Recusant Thought. 1978

17. Quinn, A. The Confidence of British Philosophers. An Essay in Historical Narrative. 1977

18. Beck, J. Le Concil de Basle (1434). 1979

19. Church, F. F. and George, T. (ed.). Continuity and Discontinuity in Church History. 1979

20. Gray, P. T. R. The Defense of Chalcedon in the East (451-553). 1979

21. Nijenhuis, W. Adrianus Saravia (c. 1532-1613). Dutch Calvinist. 1980

22. Parker, T. H. L. (ed.). Iohannis Calvini Commentarius in Epistolam Pauli ad Romanos. 1981

23. Ellis, I. Seven Against Christ. A Study of 'Essays and Reviews'. 1980

24. Brann, N. L. The Abbot Trithemius (1462-1516). 1981

25. Locher, G. W. Zwingli's Thought. New Perspectives. 1981

26. Gogan, B. The Common Corps of Christendom. Ecclesiological Themes in Thomas More. 1982

27. Stock, U. Die Bedeutung der Sakramente in Luthers Sermonen von 1519. 1982

28. Yardeni, M. (ed.). Modernité et nonconformisme en France à travers les âges. 1983

29. Platt, J. Reformed Thought and Scholasticism. 1982

30. Watts, P. M. Nicolaus Cusanus. A Fifteenth-Century Vision of Man. 1982

31. Sprunger, K. L. Dutch Puritanism. 1982

32. Meijering, E. P. Melanchthon and Patristic Thought. 1983

33. Stroup, J. The Struggle for Identity in the Clerical Estate. 1984

34. 35. Colish, M. L. The Stoic Tradition from Antiquity to the Early Middle Ages. 1.2. 2nd ed. 1990

36. Guy, B. Domestic Correspondence of Dominique-Marie Varlet, Bishop of Babylon, 1678-1742. 1986

37. 38. Clark, F. The Pseudo-Gregorian Dialogues. I. II. 1987

39. Parente, Jr. J. A. Religious Drama and the Humanist Tradition. 1987

40. Posthumus Meyjes, G. H. M. Hugo Grotius, Meletius. 1988

41. Feld, H. Der Ikonoklasmus des Westens. 1990

42. Reeve, A. and Screech, M. A. (eds.). Erasmus' Annotations on the New Testament. Acts - Romans - I and II Corinthians. 1990

43. Kirby, W. J. T. Richard Hooker's Doctrine of the Royal Supremacy. 1990

44. Gerstner, J. N. The Thousand Generation Covenant. Reformed Covenant Theology. 1990

45. Christianson, G. and Izbicki, T. M. (eds.). Nicholas of Cusa. 1991

46. Garstein, O. Rome and the Counter-Reformation in Scandinavia. 1553-1622. 1992

47. Garstein, O. Rome and the Counter-Reformation in Scandinavia. 1622-1656. 1992

48. Perrone Compagni, V. (ed.). Cornelius Agrippa, De occulta philosophia Libri tres. 1992 
49. Martin, D. D. Fifteenth-Century Carthusian Reform. The World of Nicholas Kempf. 1992

50. Hoenen, M. J. F. M. Marsilius of Inghen. Divine Knowledge in Late Medieval Thought. 1993

51. O’Malley, J. W., Izbicki, T. M. and Christianson, G. (eds.). Humanity and Divinity in Renaissance and Reformation. Essays in Honor of Charles Trinkaus. 1993

52. Reeve, A. (ed.) and Screech, M. A. (introd.). Erasmus' Annotations on the New Testament. Galatians to the Apocalypse. 1993

53. Stump, $\mathrm{Ph}$. H. The Reforms of the Council of Constance (1414-1418). 1994

54. Giakalis, A. Images of the Divine. The Theology of Icons at the Seventh Ecumenical Council. With a Foreword by Henry Chadwick. 1994

55. Nellen, H. J. M. and Rabbie, E. (eds.). Hugo Grotius - Theologian. Essays in Honour of G. H. M. Posthumus Meyjes. 1994

56. Trigg, J. D. Baptism in the Theology of Martin Luther. 1994

57. Janse, W. Albert Hardenberg als Theologe. Profil eines Bucer-Schülers. 1994

59. Schoor, R. J. M. van de. The Irenical Theology of Théophile Brachet de La Milletière (1588-1665). 1995

60. Strehle, S. The Catholic Roots of the Protestant Gospel. Encounter between the Middle Ages and the Reformation. 1995

61. Brown, M. L. Donne and the Politics of Conscience in Early Modern England. 1995

62. Screech, M. A. (ed.). Richard Mocket, Warden of All Souls College, Oxford, Doctrina et Politia Ecclesiae Anglicanae. An Anglican Summa. Facsimile with Variants of the Text of 1617. Edited with an Intro duction. 1995

63. Snoek, G. J. C. Medieval Piety from Relics to the Eucharist. A Process of Mutual Interaction. 1995

64. Pixton, P. B. The German Episcopacy and the Implementation of the Decrees of the Fourth Lateran Council, 1216-1245. Watchmen on the Tower. 1995

65. Dolnikowski, E. W. Thomas Bradwardine: A View of Time and a Vision of Eternity in FourteenthCentury Thought. 1995

66. Rabbie, E. (ed.). Hugo Grotius, Ordinum Hollandiae ac Westfrisiae Pietas (1613). Critical Edition with Translation and Commentary. 1995

67. Hirsh, J. C. The Boundaries of Faith. The Development and Transmission of Medieval Spirituality. 1996

68. Burnett, S. G. From Christian Hebraism to Jewish Studies. Johannes Buxtorf (1564-1629) and Hebrew Learning in the Seventeenth Century. 1996

69. Boland O.P., V. Ideas in God according to Saint Thomas Aquinas. Sources and Synthesis. 1996

70. Lange, M.E. Telling Tears in the English Renaissance. 1996

71. Christianson, G. and Izbicki, T.M. (eds.). Nicholas of Cusa on Christ and the Church. Essays in Memory of Chandler McCuskey Brooks for the American Cusanus Society. 1996

72. Mali, A. Mystic in the New World. Marie de l'Incarnation (1599-1672). 1996

73. Visser, D. Apocalypse as Utopian Expectation (800-1500). The Apocalypse Commentary of Beren gaudus of Ferrières and the Relationship between Exegesis, Liturgy and Iconography. 1996

74. O'Rourke Boyle, M. Divine Domesticity. Augustine of Thagaste to Teresa of Avila. 1997

75. Pfizenmaier, T. C. The Trinitarian Theology of Dr. Samuel Clarke (1675-1729). Context, Sources, and Controversy. 1997

76. Berkvens-Stevelinck, C., Israel, J. and Posthumus Meyjes, G. H. M. (eds.). The Emergence of Tolerance in the Dutch Republic. 1997

77. Haykin, M. A. G. (ed.). The Life and Thought of John Gill (1697-1771). A Tercentennial Appreciation. 1997

78. Kaiser, C. B. Creational Theology and the History of Physical Science. The Creationist Tradition from Basil to Bohr. 1997

79. Lees, J. T. Anselm of Havelberg. Deeds into Words in the Twelfth Century. 1997

80. Winter, J. M. van. Sources Concerning the Hospitallers of St John in the Netherlands, 14th-18th Centuries. 1998

81. Tierney, B. Foundations of the Conciliar Theory. The Contribution of the Medieval Canonists from Gratian to the Great Schism. Enlarged New Edition. 1998

82. Miernowski, J. Le Dieu Néant. Théologies négatives à l’aube des temps modernes. 1998

83. Halverson, J. L. Peter Aureol on Predestination.A Challenge to Late Medieval Thought. 1998.

84. Houliston, V. (ed.). Robert Persons, S.J.: The Christian Directory (1582). The First Booke of the Christian Exercise, appertayning to Resolution. 1998

85. Grell, O. P. (ed.). Paracelsus. The Man and His Reputation, His Ideas and Their Transformation. 1998

86. Mazzola, E. The Pathology of the English Renaissance. Sacred Remains and Holy Ghosts. 1998.

87. 88. Marsilius von Inghen. Quaestiones super quattuor libros sententiarum. Super Primum. Bearbeitet von M. Santos Noya. 2 Bände. I. Quaestiones 1-7. II. Quaestiones 8-21. 2000 
89. Faupel-Drevs, K. Vom rechten Gebrauch der Bilder im liturgischen Raum. Mittelalterliche Funktionsbestimmungen bildender Kunst im Rationale divinorum officiorum des Durandus von Mende (1230/11296). 1999

90. Krey, P. D. W. and Smith, L. (eds.). Nicholas of Lyra. the Senses of Scripture. 2000

92. Oakley, F. Politics and Eternity. Studies in the History of Medieval and Early-Modern Political Thought. 1999

93. Pryds, D. The Politics of Preaching. Robert of Naples (1309-1343) and his Sermons. 2000

94. Posthumus Meyjes, G. H. M. Jean Gerson - Apostle of Unity. His Church Politics and Ecclesiology. Translated by J. C. Grayson. 1999

95. Berg, J. van den. Religious Currents and Cross-Currents. Essays on Early Modern Protestantism and the Protestant Enlightenment. Edited by J. de Bruijn, P. Holtrop, and E. van der Wall. 1999

96. Izbicki, T. M. and Bellitto, C. M. (eds.). Reform and Renewal in the Middle Ages and the Renaissance. Studies in Honor of Louis Pascoe, S. J. 2000

97. Kelly, D. The Conspiracy of Allusion. Description, Rewriting, and Authorship from Macrobius to Medieval Romance. 1999

98. Marrone, S. P. The Light of Thy Countenance. Science and Knowledge of God in the Thirteenth Century. 2 volumes. 1. A Doctrine of Divine Illumination. 2. God at the Core of Cognition. 2001

99. Howson, B. H. Erroneous and Schismatical Opinions. The Question of Orthodoxy regarding the Theology of Hanserd Knollys (c. 1599-169)). 2001

100. Asselt, W. J. van. The Federal Theology of Johannes Cocceius (1603-1669). 2001

101. Celenza, C.S. Piety and Pythagoras in Renaissance Florence the Symbolum Nesianum. 2001

102. Dam, H.- J. van (ed.), Hugo Grotius, De imperio summarum potestatum circa sacra. Critical Edition with Introduction, English translation and Commentary. 2 volumes. 2001

103. Bagge, S. Kings, Politics, and the Right Order of the World in German Historiography c. 950-1150. 2002

104. Steiger, J. A. Fünf Zentralthemen der Theologie Luthers und seiner Erben. Communicatio - Imago Figura - Maria - Exempla. Mit Edition zweier christologischer Frühschriften Johann Gerhards. 2002

105. Izbicki, T. M. and Bellitto, C. M. (eds.). Nicholas of Cusa and his Age: Intellect and Spirituality. Essays Dedicated to the Memory of F. Edward Cranz, Thomas P. McTighe and Charles Trinkaus. 2002

106. Hascher-Burger, U. Gesungene Innigkeit. Studien zu einer Musikhandschrift der Devotio moderna (Utrecht, Universiteitsbibliotheek, MS 16 H 94, olim B 113). Mit einer Edition der Gesänge. 2002

107. Bolliger, D. Infiniti Contemplatio. Grundzüge der Scotus- und Scotismusrezeption im Werk Huldrych Zwinglis. 2003

108. Clark, F. The 'Gregorian’ Dialogues and the Origins of Benedictine Monasticism. 2002

109. Elm, E. Die Macht der Weisheit. Das Bild des Bischofs in der Vita Augustini des Possidius und andere spätantiken und frühmittelalterlichen Bischofsviten. 2003

110. Bast, R. J. (ed.). The Reformation of Faith in the Context of Late Medieval Theology and Piety. Essays by Berndt Hamm. 2004.

111. Heering, J. P. Hugo Grotius as Apologist for the Christian Religion. A Study of his Work De Veritate Religionis Christianae (1640). Translated by J.C. Grayson. 2004.

112. Lim, P. C.- H. In Pursuit of Purity, Unity, and Liberty. Richard Baxter's Puritan Eccle siology in its Seventeenth-Century Context. 2004.

113. Connors, R. and Gow, A. C. (eds.). Anglo-American Millennialism, from Milton to the Millerites. 2004.

114. Zinguer, I. and Yardeni, M. (eds.). Les Deux Réformes Chrétiennes. Propagation et Diffusion. 2004.

115. James, F. A. III (ed.). Peter Martyr Vermigli and the European Reformations: Semper Reformanda. 2004.

116. Stroll, M. Calixtus II (1119-1124). A Pope Born to Rule. 2004.

117. Roest, B. Franciscan Literature of Religious Instruction before the Council of Trent. 2004.

118. Wannenmacher, J. E. Hermeneutik der Heilsgeschichte. De septem sigillis und die sieben Siegel im Werk Joachims von Fiore. 2004.

119. Thompson, N. Eucharistic Sacrifice and Patristic Tradition in the Theology of Martin Bucer, 1534-1546. 2005 .

120. Van der KooI, C. As in a Mirror. John Calvin and Karl Barth on Knowing God. A Diptych. 2005.

121. Steiger, J. A. Medizinische Theologie. Christus medicus und theologia medicinalis bei Martin Luther und im Luthertum der Barockzeit. 2005.

122. Giakalis, A. Images of the Divine. The Theology of Icons at the Seventh Ecumenical Council - Revised Edition. With a Foreword by Henry Chadwick. 2005.

123. Heffernan, T. J. and Burman, T. E. (eds.). Scripture and Pluralism. Reading the Bible in the Religiously Plural Worlds of the Middle Ages and Renaissance. Papers Presented at the First Annual Symposium of the Marco Institute for Medieval and Renaissance Studies at the University of Tennessee, Knoxville, February 21-22, 2002. 2005. 
124. Litz, G., Munzert, H. and Liebenberg, R. (eds.). Frömmigkeit - Theologie - Frömmigkeitstheologie Contributions to European Church History.

125. Ferreiro, A. Simon Magus in Patristic, Medieval and Early Modern Traditions. 2005.

126. Goodwin, D. L. "Take Hold of the Robe of a Jew". Herbert of Bosham's Christian Hebraism. 2006.

127. Holder, R. W. John Calvin and the Grounding of Interpretation. Calvin's First Commentaries. 2006.

128. Reilly, D. J. The Art of Reform in Eleventh-Century Flanders. Gerard of Cambrai, Richard of SaintVanne and the Saint-Vaast Bible. 2006.

129. Frassetto, M. (ed.). Heresy and the Persecuting Society in the Middle Ages. Essays on the Work of R.I. Moore. 2006.

130. Walters Adams, G. Visions in Late Medieval England. Lay Spirituality and Sacred Glimpses of the Hidden Worlds of Faith. 2007.

131. Kirby, T. The Zurich Connection and Tudor Political Theology. 2007.

132. Mackay, C.S. Narrative of the Anabaptist Madness. The Overthrow of Münster, the Famous Metropolis of Westphalia (2 vols.). 2007.

133. Leroux, N.R. Martin Luther as Comforter. Writings on Death. 2007.

134. Tavuzzi, M. Renaissance Inquisitors. Dominican Inquisitors and Inquisitorial Districts in Northern Italy, 1474-1527. 2007.

135. Baschera, L. and C. Moser (eds.). Girolamo Zanchi, De religione christiana fides - Confession of Christian Religion (2 vols.). 2007.

136. Hurth, E. Between Faith and Unbelief. American Transcendentalists and the Challenge of Atheism. 2007.

137. Wilkinson R.J. Orientalism, Aramaic and Kabbalah in the Catholic Reformation. The First Printing of the Syriac New Testament. 2007.

138. Wilkinson R.J. The Kabbalistic Scholars of the Antwerp Polyglot Bible. 2007.

139. Boreczky E. John Wyclif's Discourse On Dominion in Community. 2007.

140. Dowd C. Rome in Australia: The Papacy and Conflict in the Australian Catholic Missions, 1834-1884 (2 vols.). 2008.

141. Perrone S.T. Charles $V$ and the Castilian Assembly of the Clergy. Negotiations for the Ecclesiastical Subsidy. 2008.

142. Smith, K.A. and S. Wells (eds.). Negotiating Community and Difference in Medieval Europe. Gender, Power, Patronage and the Authority of Religion in Latin Christendom. 2009.

143. Mixson, J.D. Poverty's Proprietors. Ownership and Mortal Sin at the Origins of the Observant Movement. 2009.

144. Moser, C. and P. Opitz (eds.). Bewegung und Beharrung. Aspekte des reformierten Protestantismus, 1520-1650. 2009.

145. Henriksen, E. Milton and the Reformation Aesthetics of the Passion. 2010.

146. Martínez, H.S. Alfonso X, the Learned. Translated by O. Cisneros. 2010.

147. Biller, P., Bruschi, C. and S. Sneddon(eds.). Inquisitors and Heretics in Thirteenth-Century Languedoc. Edition and Translation of Toulouse Inquisition Depositions, 1273-1282. 2010.

148. Dahl, G. Book Collections of Clerics in Norway, 1650-1750. 2010.

149. Travassos Valdez, M.A. Historical Interpretations of the "Fifth Empire". The Dynamics of Periodization from Daniel to António Vieira, S.J. 2010.

150. Roldán-Figueroa, R. The Ascetic Spirituality of Juan de Ávila (1499-1569). 2010.

151. Abé, T. The Jesuit Mission in New France. A New Interpretation in the Light of the Earlier Jesuit Experience in Japan. 2010.

brill.nl/shct 